\title{
Äldre människors föreställningar om den egna framtiden, döendet och döden
}

\author{
Magnus Broström
}

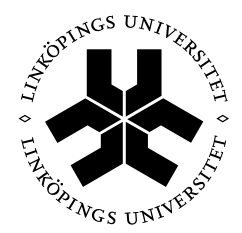

\section{Linköpings universitet \\ FILOSOFISKA FAKULTETEN}

Linköping Studies in Arts and Science No. 612

Linköpings Universitet, Institutionen för samhälls- och välfärdsstudier NISAL (Nationella institutet för forskning om äldre och åldrande)

Norrköping 2014 
Linköping Studies in Arts and Science $•$ No. 612

Vid filosofiska fakulteten vid Linköpings universitet bedrivs forskning och ges forskarutbildning med utgångspunkt från breda problemområden. Forskningen är organiserad i mångvetenskapliga forskningsmiljöer och forskarutbildningen huvudsakligen i forskarskolor. Gemensamt ger de ut serien Linköping Studies in Arts and Science. Denna avhandling kommer från NISAL (Nationella institutet för forskning om äldre och åldrande) vid Institutionen för samhälls- och välfärdsstudier

Distribueras av:

Institutionen för samhälls- och välfärdsstudier

NISAL (Nationella institutet för forskning om äldre och åldrande)

Linköpings universitet

60174 Norrköping

Magnus Broström

Äldre människors föreställningar om den egna framtiden, döendet och döden

Upplaga 1:1

ISBN 978-91-7519-379-3

ISSN 0282-9800

(C) Magnus Broström

Institutionen för samhälls- och välfärdsstudier 2014

Tryckeri: LiU-Tryck, Linköping 2014

Omslagsbild: Dörren, oljemålning av Kristina Landell 1992 


\section{Abstract}

Syftet med avhandlingen är att utforska äldre människors föreställningar om och förhållningssätt till den egna framtiden, döendet och döden. Det är ämnen som hittills har fått begränsad uppmärksamhet. En bakomliggande orsak till detta är att äldreforskning och dödsforskning sällan har förenats. Dessutom synliggörs äldres döende och död nästan inte alls i offentlig debatt, trots att ålderdomen är den fas i livet då döden normalt inträffar. Studien bygger på kvalitativa intervjuer med 27 äldre kvinnor och män i åldrarna 70 år till 91 år, vilka alla bodde i ordinärt boende och betraktade sig själva som relativt friska. Genomförande, analys och tolkning av intervjuerna utgick från ett livsloppsperspektiv, där både en abduktiv och en hermeneutisk ansats tillämpades. I analys och tolkning framkom kontrasterande mönster i de intervjuades funderingar på den egna framtiden och döden, i deras samtal med någon om döden, deras erfarenheter av döende och död, och vad de trodde hände efter döden. Resultaten visar också att funderingar och agerande inför en krympande framtid utgjorde centrala inslag i de äldres vardag och att de intervjuade laborerade med olika tidshorisonter. Ett annat resultat handlar vad som är rätt tidpunkt i livet för att fundera på döden, samtala med andra om döden, för att planera inför döden och ett "efter döden". Det är en komplex bild av äldres föreställningar om den egna framtiden, döendet och döden som framkommit, där teman som åldersmönster, ett förlängt livslopp, ansvar, kontroll och värdighet är centrala inslag. Avhandlingens resultaten kan bidra till en bättre förståelse av äldre människors situation i ljuset av en krympande framtid, döende och död.

Nyckelord: tid, äldre, framtid, döende, död, åldrande, livsloppsperspektiv 



\section{Förord}

Det är många som på olika sätt har bidragit till denna avhandling. Först och främst vill jag rikta ett mycket stort tack till min huvudhandledare Eva Jeppsson Grassman och min bihandledare Anna Whitaker. Jag är tacksam för ert tålamod och för den tid och det engagemang ni har lagt ner i mitt avhandlingsprojekt. Det har varit ett privilegium att som doktorand fått ta del av era erfarenheter och ert kunnande. Tack Eva för idé till omslag!

Dessutom vill jag rikta ett varmt tack till alla 27 intervjupersoner som ingår i studien och som så generöst har delat med sig av sin tid och sina livserfarenheter.

Ett stort tack riktas också till mina kollegor och medarbetare på NISAL för er support, och till mina doktorandkollegor för värdefulla kommentarer och inspiration, tack Anna Siverskog, Annsofie Mahrs Träff, Ida Kåhlin, Jessica Berg, Joy Torgé, Laura Machat-From, Veronika Wallroth och Åsa Roin.

Jag vill tacka alla som har kommenterat mitt manus vid avhandlingsseminarier - Elisabet Cedersund, Evy Gunnarsson, Anna Milberg och Eva Reimers. Jag vill också tacka Anna Martin som har varit behjälplig i de många administrativa spörsmål som rör avhandlingsskrivandet. Tack också Louise Olsson för ditt stöd och allt "döden, döden prat". Jag vill även särskilt tacka Gunilla Rapp för språkgranskning och Joy Torgé för den engelska översättningen av sammanfattningen.

Sist, men inte minst, vill jag tacka mina närmaste, min mamma, Barbro, och min bror Peter med familj för all energi ni bidragit med, och ett särskilt tack till min familj Åsa, Clara och Stella för ert tålamod och era uppmuntrande ord under denna resa.

Norrköping den 3 april 2014

Magnus Broström 



\section{Innehåll}

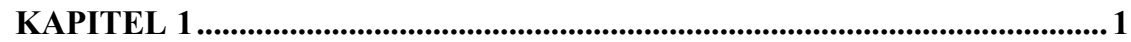

Äldres framtid, döende och död ..............................................................1

Dödens position i det socialgerontologiska forskningsfältet............................. 2

Dödens position i dagens samhälle ............................................................. 5

Varför studera det valda området? ............................................................. 10

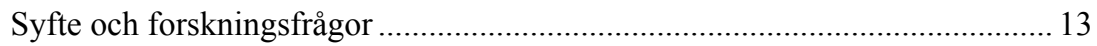

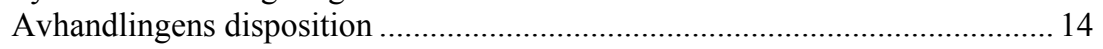

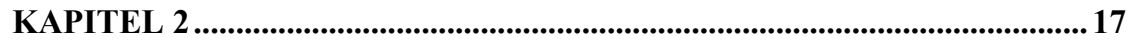

Tidigare forskning och teoretiskt ramverk.................................................17

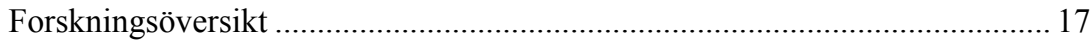

Andras syn på äldres framtid.................................................................... 18

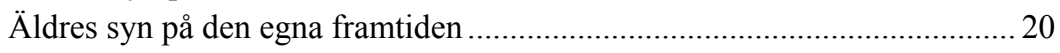

Andras syn på äldres döende och död ......................................................... 21

Äldres syn på det egna döendet och döden ................................................... 22

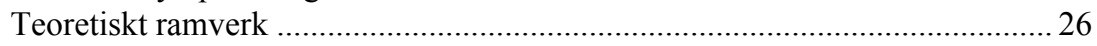

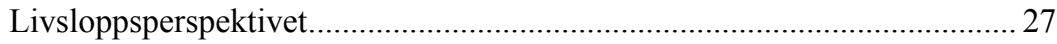

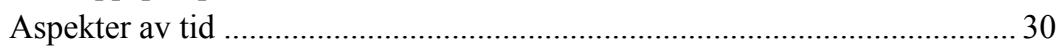

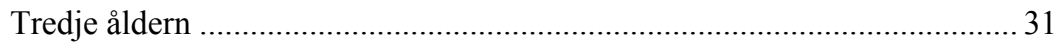

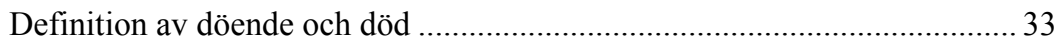

Olika synsätt på döende och död................................................................ 34

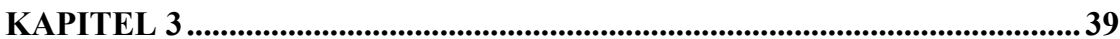

Metoder, material och genomförande .........................................................39

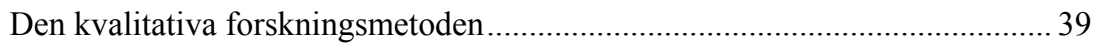

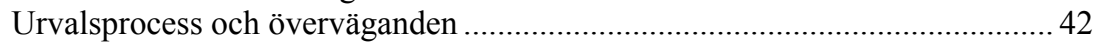

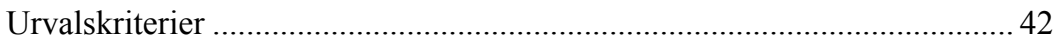

Hur och var fann jag intervjupersonerna? ............................................. 43

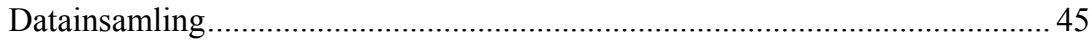

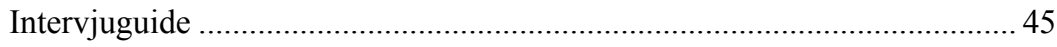

Reflektioner kring intervjuförfarande och transkribering .......................... 46

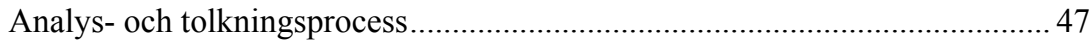

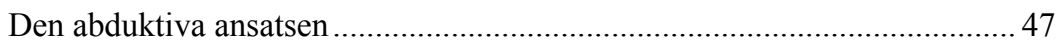

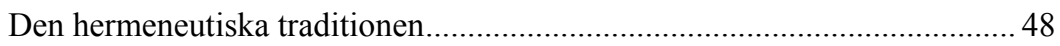

Analys av insamlade data ....................................................................... 50

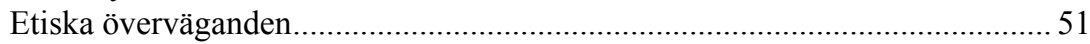

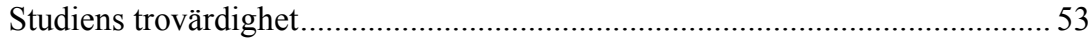

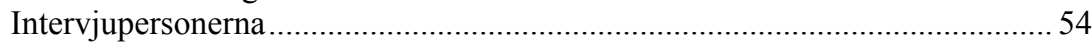




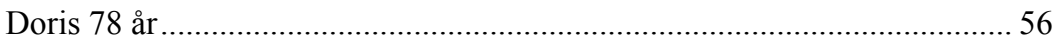

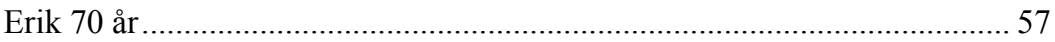

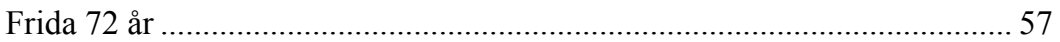

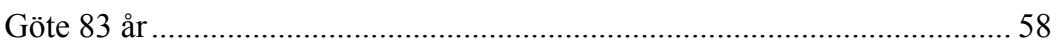

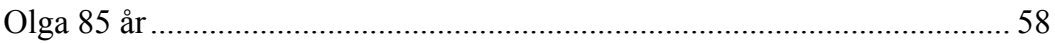

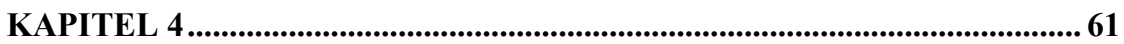

Möten med döende och död genom livet ................................................................... 61

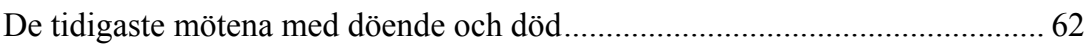

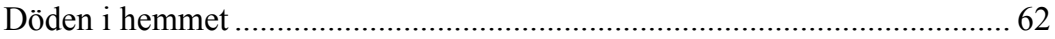

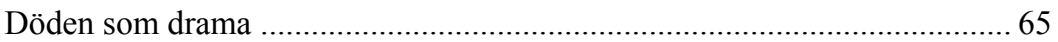

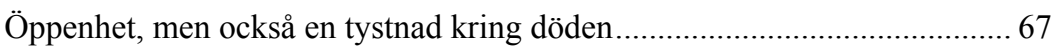

Möten med döende och död mitt i livet............................................................... 69

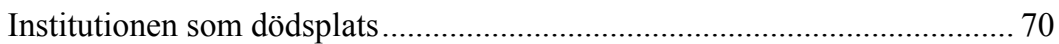

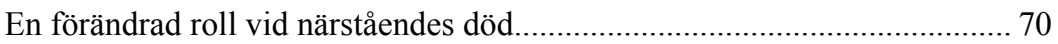

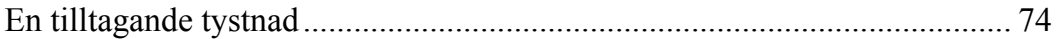

Möten med döende och död de allra senaste åren ............................................ 76

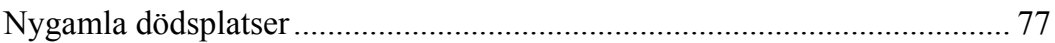

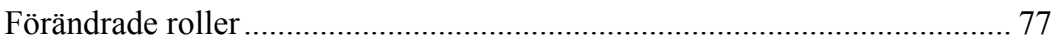

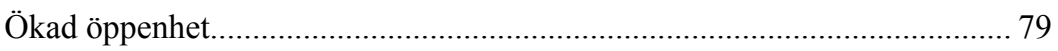

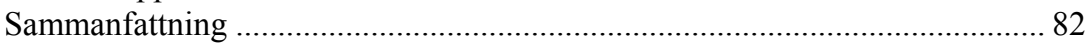

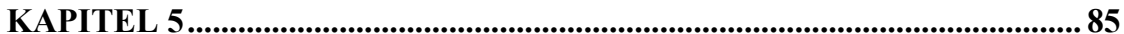

Tankar i vardagen på döende och död .........................................................85

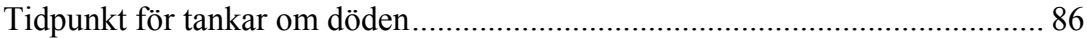

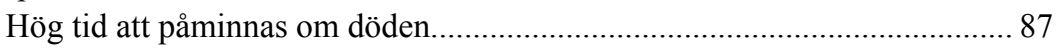

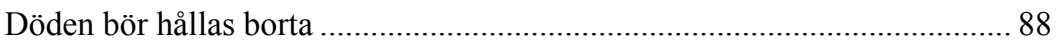

Rum som väcker tankar om döende och död ................................................ 90

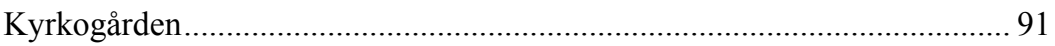

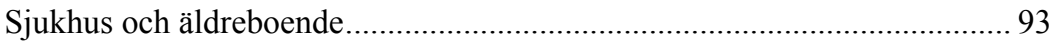

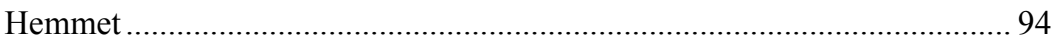

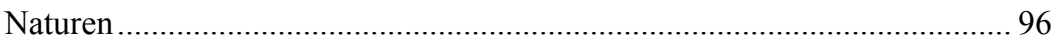

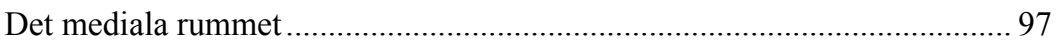

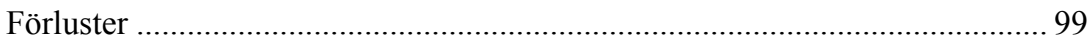

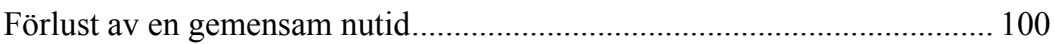

Förlust av ett gemensamt förflutet ......................................................... 102

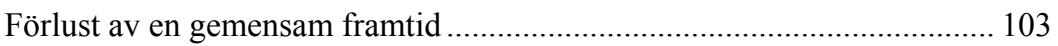

Att hantera funderingar på döende och död ................................................. 104

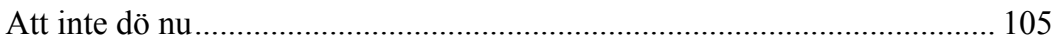

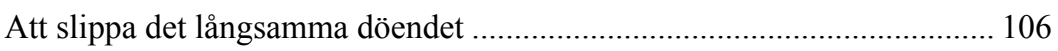

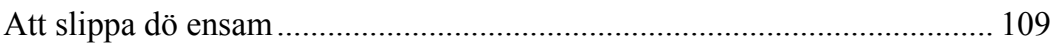

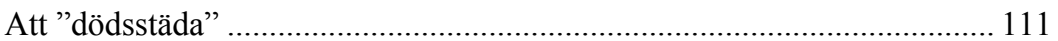

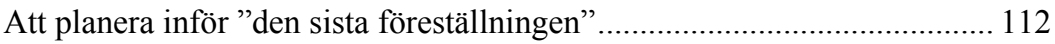

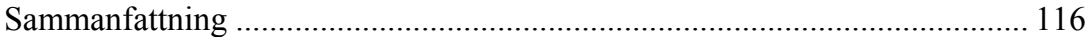


KAPITEL 6

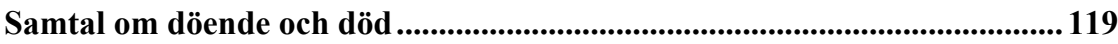

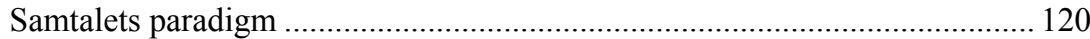

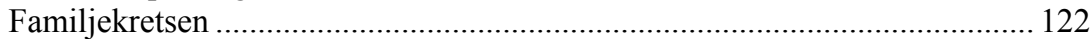

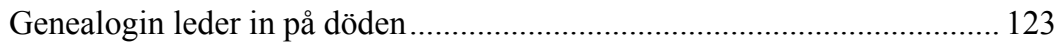

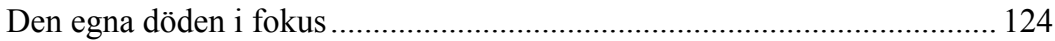

Tillsammans med barnbarnen bryts tystnaden ............................................. 126

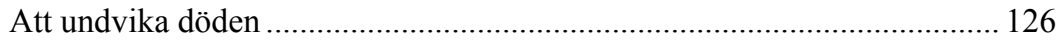

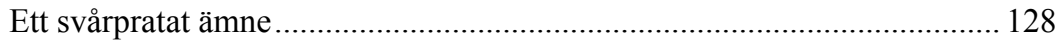

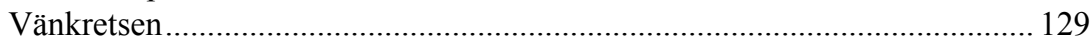

Vi tangerar ämnet döden ........................................................................ 130

Förtroende och gemensamma erfarenheter ............................................... 132

Ett olämpligt samtalsämne .................................................................. 133

Ett ämne som väcker rädsla................................................................ 134

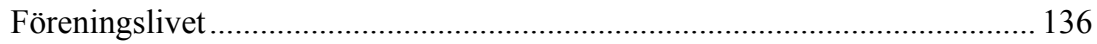

Döden passar inte i föreningslivet .......................................................... 137

Att dryfta döden i föreningslivet ........................................................ 137

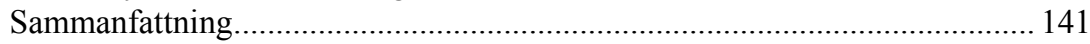

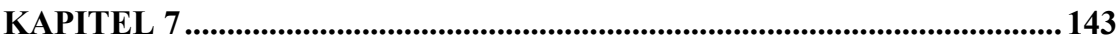

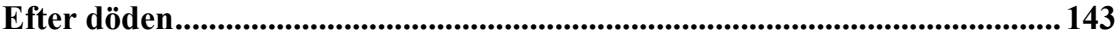

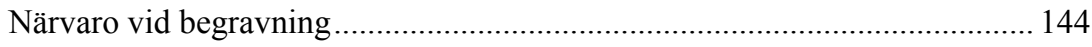

Ett värdigt och oförglömligt sista farväl.................................................... 145

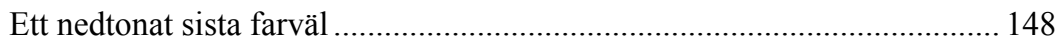

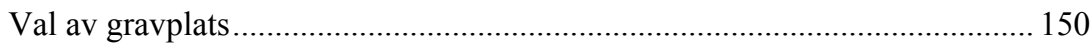

Det ska synas var man är begravd ........................................................... 150

Det spelar ingen större roll var man gravsätts .......................................... 151

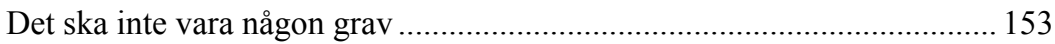

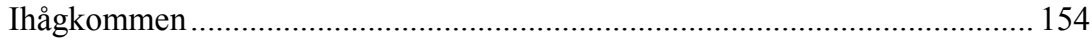

Att förbli odödlig i minnet hos efterlevande ............................................ 155

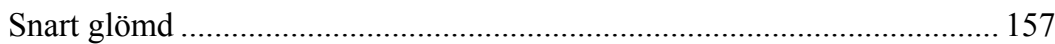

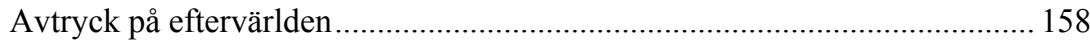

Att förbli odödlig i det "offentliga minnet" ............................................. 158

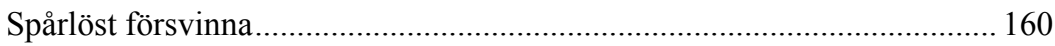

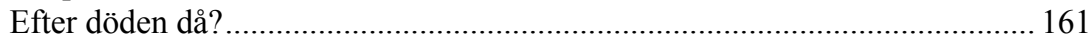

Ett liv efter döden utifrån en tro ................................................................... 162

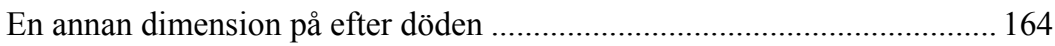

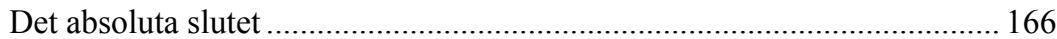

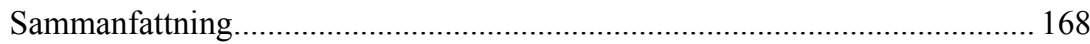




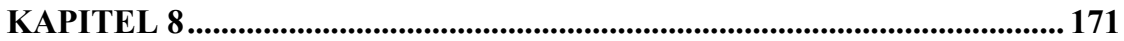

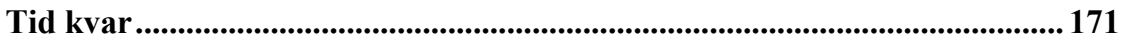

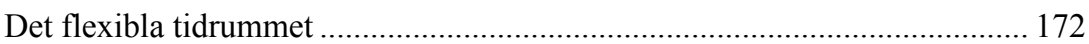

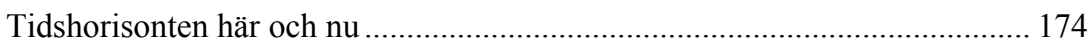

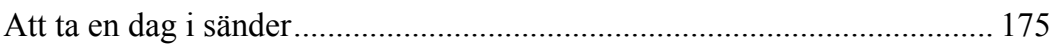

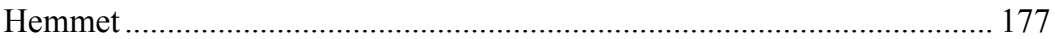

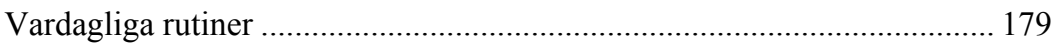

Ingen större idé att planera eller drömma om framtiden ............................ 179

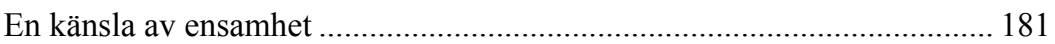

Tidshorisonten på visst avstånd..................................................................... 182

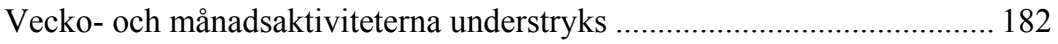

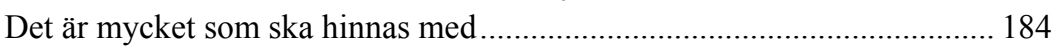

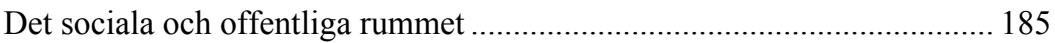

Tidshorisonten ganska långt borta............................................................... 186

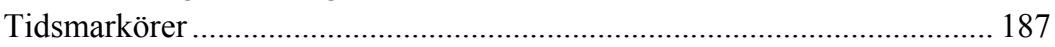

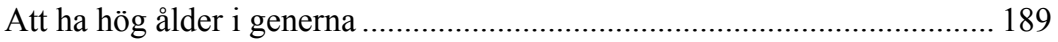

Det finns en hel del kvar att uträtta ......................................................... 190

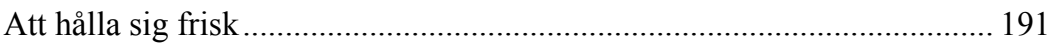

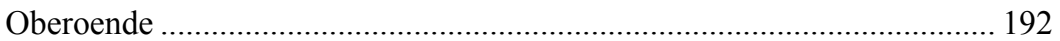

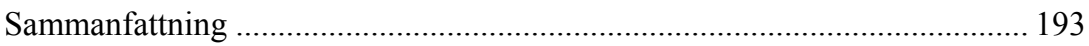

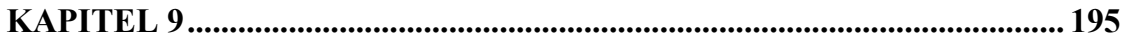

Sammanfattande resultat och slutdiskussion ................................................... 195

Studiens övergripande resultat .................................................................. 196

Hur beskriver äldre människor sina tidigare erfarenheter

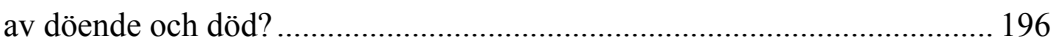

Hur ser äldre människor på sitt eget döende och på sin egen död?.............. 197

Vilka erfarenheter har äldre människor av möten

med döende och död i det vardagliga livet?................................................ 198

Vilka föreställningar har äldre människor kring

vad som kommer att ske efter den egna döden?........................................ 199

Hur ser äldre människor på sin framtid och på den tid som är kvar?.......... 200

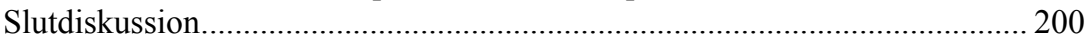

En komplex bild av äldre människors föreställningar

om det egna döendet och döden .................................................................. 201

En komplex bild av äldre människors föreställningar

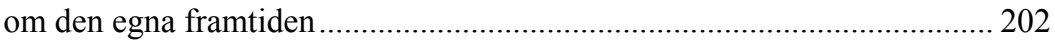

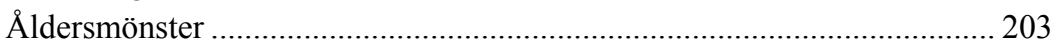

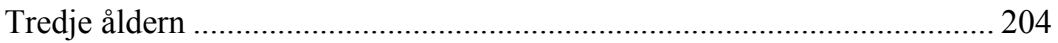

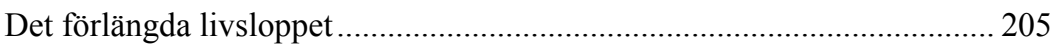

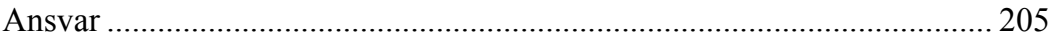

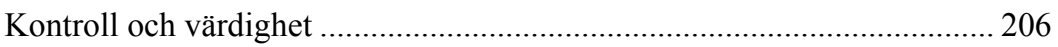


SUMMARY ......................................................................................................209

Older people's future, dying and death.......................................................... 209

Aim and research questions....................................................................... 210

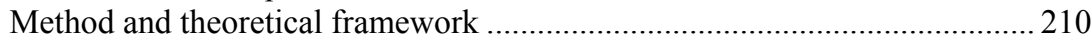

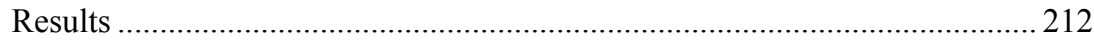

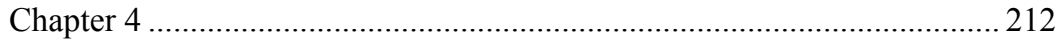

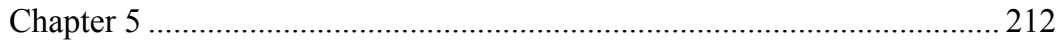

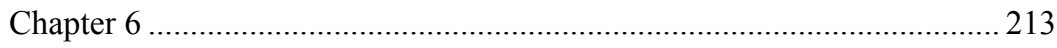

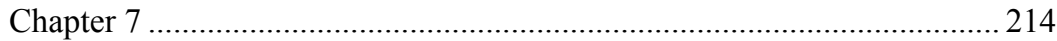

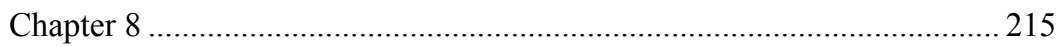

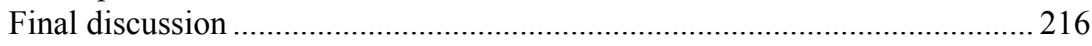

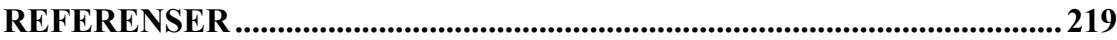

BILAGA 1 - INFORMATIONSBREV

BILAGA 2 - INTERVJUGUIDE

\section{TABELLFÖRTECKNING}

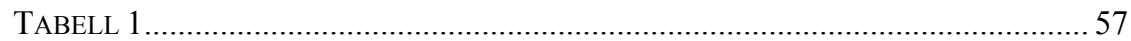





\section{KAPITEL 1}

\section{Äldres framtid, döende och död}

Jag sitter hemma hos Elsa och Carl, båda 71 år, i deras kök och genomför intervjun. Det är februari, töväder och vi sitter inne i värmen och pratar om livet som varit, om framtiden och om döden. De berättar att de har känt varandra sedan småskolan och att de nu har varit gifta i drygt 50 år. Deras gemensamma livshistoria har kantats av glädje såväl som av sorg och de betonar att de stöttar varandra i både medgång och motgång och så har de alltid gjort. När vi berör frågor om framtiden blir tonen allvarsam och mycket av deras funderingar kommer att handla om att någon av dem förr eller senare kommer att bli änka eller änkling - den stora skräcken är att bli lämnad ensam och vad det kan få för privata, sociala och ekonomiska följder. Carl börjar också tycka - "Det är inga lätta frågor du har!". När vi senare börjar samtala om döende och död skiftar samtalstonen och diskussionen blir mindre allvarsam och blandas då och då med inslag av humor, självdistans och eftertänksamhet. I slutet av intervjun ställer jag frågan: "Vad tror ni kommer att hända efter döden?", och på den svarar Elsa skrattandes: "Ja, den som visste det, då kanske man skulle dött i dag". Carl säger efter en stund: "Det är kanske bra att det är en gåta. Då kan man ha någon form av hopp om att det finns något, att det inte bara är ett kolsvart mörker utan att det finns någonting, så länge man ingenting vet så finns ju det hoppet".

Det enda vi människor med säkerhet vet om livet och om framtiden är att vi en dag kommer att dö. Det brukar sägas att vi människor är den enda levande varelse som vet om att vi ska dö (jfr Kellehear, 2007a, s. 11ff), och denna vår död utgör "kanske den händelse som mer än någon annan ber om att bli förstådd, men inte kan bli det" (Hirdman, 2012, s. 8). Sociologen Bauman anser att en bakomliggande orsak till att döden inte går att förstå är att:

det enda som tänkandet inte kan begripa är sin egen icke-existens: det kan inte föreställa sig en tid eller en plats där det inte längre finns, eftersom all föreställning omfattar tänkandet, tankeförmågan, som den "frambesvärjande makten". [...] Döden är när allt kommer omkring just det otänkbara: ett tillstånd utan tänkande; ett tillstånd vi inte kan åskådliggöra - eller ens konstruera begreppsligt. Men döden är, den är verklighet, och vi vet om det (Bauman, 1994, s. 27, författarens kursivering). 
Att tänkandet inte kan begripa sin egen icke-existens, innebär emellertid inte att vi människor inte kan reflektera över eller förhålla oss till fenomenet döden. Att vi ska dö, denna inte sällan smärtsamma vetskap, och det sätt på vilken den hanteras, anses vara det centrala för hur vi människor formar vårt samhälle såväl som våra egna liv. Vetskap om att vi alla ska dö är alltså inget främmande. Däremot kan vi förhålla oss till döden på olika sätt bland annat beroende på tid och rum (Hirdman, 2012; Magnusson, 2000; Walter, 1994). I vår tid förknippas ofta döden med ålderdomen, det är då de flesta människor dör i dag och det är då, så småningom, de allra flesta av oss kommer att dö. Frågan är hur äldre människor, vars kvarvarande tid successivt krymper, förhåller sig till denna insikt?

Ämnet för denna studie är äldre människors framtid, döende och död. Avsikten är att utifrån 27 relativt friska äldre människors - i åldern 70-91 år egna berättelser undersöka och förstå vilka föreställningar de har om sin egen framtid, döende och död. Funderar och tänker de på den egna framtiden eller den egna döden? Samtalar de med någon eller några om döendet och döden? Vilka erfarenheter har de av andra människors döende och död? Vad tror de händer efter den egna döden? Detta är några av de frågor som jag kommer att diskutera i de kommande kapitlen. För att kunna analysera och förstå hur de här individerna förhåller sig till den egna framtiden, döendet och döden används ett livsloppsperspektiv, där hela deras livsprocess - dåtid, nutid och framtid - tas i beaktande.

\section{Dödens position i det socialgerontologiska forskningsfältet}

Studien har genomförts med den socialgerontologiska disciplinen som utgångspunkt. Frågan är då vilket utrymme temat döden har inom det socialgerontologiska forskningsfältet. Gerontologi är det begrepp som betecknar det vetenskapliga studiet av åldrandet. Enligt Nordisk Gerontologisk Förening (NGF) är gerontologi läran "om åldrandet och studiet av åldersrelaterade förändringar i livsprocesser från uppnådd mognad och till individens död. Gerontologi omfattar basalbiologiska och kliniskmedicinska, humanistiska och samhällsvetenskapliga discipliner". Vanligtvis delas begreppet gerontologi i två underdiscipliner, det vill säga, socialgerontologi och geriatrik. Geriatriken handlar ofta om de biologiska och medicinska perspektiven på åldrandet (det sjuka åldrandet), medan socialgerontologin handlar om de psykologiska, socialpsykologiska och sociala perspektiven på åldrandet (det friska åldrandet) (Tornstam, 2005, s. 9). Trots att både den socialgerontologiska och den geriatriska forskningens syfte är att studera åldersrelaterade förändringar i livsprocessen, precis som NGF:s definition ovan lyder, så tycks de två disciplinerna sällan omfatta studiet av äldre människors döende och död: "Even the bench- 
mark sixth edition of the 2006 Handbook of aging and the social sciences is so blind to these matters that neither the word 'death' nor the word 'spirituality' appear in the index" (Johnson, 2009, s. 660; Binstock \& George, 2006).

Det sägs dock ibland att knappast något annat ämne än döden under världshistoriens gång har blivit så uppmärksammat av litteraturvetare, historiker, teologer, filosofer, sociologer med flera. När det däremot handlar om forskning med inriktning på äldres döende och död så är den förhållandevis sparsam på grund av att detta döende i mångt och mycket har försummats. En bakomliggande orsak är, menar forskare, att det knappt finns något intresse av att förena äldreforskning och dödsforskning (Tomer, 2000a, s. xiv). Psykologen Neimeyer (2000, s. vii) menar att "the conjunction of death and late adulthood is marked by irony": Statistiken visar tydligt att flertalet i dag dör under ålderdomen, och att det är då, i denna livsfas, som äldre också ofta förlorar sin partner och sina vänner. Forskningen visar att äldre människor utgör den åldersgrupp som statistiskt sett begår flest självmord på grund av depression, känsla av ensamhet eller på grund av fysisk smärta i ett terminalt skede. Fler faktorer samverkar emellertid till att det knappast skrivs om de här levnadsförhållandena. Bland annat riktas uppmärksamheten oftast mot yngre generationers döende och död. Medicinska och tekniska aspekter betonas framför mänskliga perspektiv som vård och omsorg vid livets slut. Mot denna bakgrund, menar Neimeyer, blir sällan de mänskliga dimensionerna i mötet mellan död och äldre människor studerade (Neimeyer, 2000, s. vii).

Ett antal forskare inom socialgerontologin, och även inom angränsande forskningsområden, anser det anmärkningsvärt att så få studier uppmärksammar äldres döende och död (Johnson, 2009, s. 659ff; Rahm Hallberg, 2004, s. 99; 2010, s. 87f; Seale, 1998, s. 44; Whitaker, 2010; se även Socialstyrelsen, 2007). Åsidosättande av äldreforskningen tycks ha flera orsaker. Socialgerontologen Johnson pekar på att andra ämnen prioriteras framför forskning om äldres framtid, döende och död, och att det också tycks finnas en allmän motvilja bland forskare att studera äldres död:

Perhaps gerontologists are not very spiritual or are like so many others captured by the "death taboo" identified by Ariés (1981) or its "sequestration" as Giddens (1991) chose to describe it. Whatever the reasons, there is a marked aversion to addressing end-of-life issues among researchers and writers on aging. While we may describe our field of study as "the study of aging and life span", comparatively little attention is given in the literature to the far end of the life span - death - or psychosocial aspects of the endings of lives. There is a body of work, of course. But in volume, it is massively outranked by social gerontological inquiries into families, generational relations, long-term care, pensions, ethnicity, gender, work and retirement (Johnson, 2009, s. 659). 
Även inom den geriatriska forskningen är frånvaron av ämnet döden påtaglig i akademiska publikationer. Anledningen till att knappast något skrivs om äldres döende och död inom detta ämnesområde, menar sociologen Seale, kan handla om att forskaren i större utsträckning hellre betonar vikten av att upprätthålla liv genom att lindra effekterna av kroppsligt och mentalt förfall hos skröpliga människor, än att samtala med dem om deras döende och död (Seale, 1998, s. 44). Socialgerontologen Lloyd instämmer i att det tidigare svala intresset för de här frågorna delvis har sin förklaring i den gerontologiska forskningens fokus på att motverka just negativa bilder av åldrandet. Hon hävdar emellertid att forskare inom gerontologin har börjat intressera sig för frågor kring äldres döende och död (Lloyd, 2010, s. 618).

Med anledning av ämnets påtagliga marginalisering inom socialgerontologin menar flera forskare att det finns åtskilliga skäl att lyfta fram det som den socialgerontologiska forskningen kan bidra med. Inte minst genom att påtala vad som föranleder att ämnet - äldres framtid, döende och död - är och kommer att bli allt viktigare framöver. Ett argument för fortsatt forskning är - i kontrast till tidigare historiska perioder i Sverige och även utifrån en europeisk kontext - att döden då var vanligt förekommande bland de yngre generationerna på grund av hög barnadödlighet och svåra epidemier. Döden i dagens svenska samhälle är något som tillhör ålderdomens livsfaser och något som anses som "onaturligt" i de yngre åldrarna (Jönson, 2002, s. 16; Rahm Hallberg, 2010, s. 90f). Att döden tillhör ålderdomen visar också SCB:s (2012) siffror. Under år 2010 avled drygt 90000 personer i Sverige, varav cirka 80 procent var 65 år eller äldre. I dag är 7 av 10 kvinnor och 6 av 10 män 80 år och äldre när de dör.

Ett annat argument som motiverar fortsatt forskning är att förbättrade levnadsvillkor och medicinska framsteg innebär att medellivslängden i Sverige successivt kommer att öka och förändra befolkningsstrukturens sammansättning. De äldres antal kommer att öka påtagligt. Om överlevnaden fortsätter att utvecklas som under de senaste decennierna förväntas hälften av de flickor som föddes år 2011 uppnå 93 år. För pojkarna kan hälften leva vid 91 års ålder (SCB, 2012)1. Med andra ord, vi lever längre, men i takt med att andelen äldre ökar i samhället, och också antalet mycket gamla blir följden att allt fler äldre blir multisjuka, samt att det långsamma och utdragna döendet blir vanligare (Tännsjö, 2009, s. 14). Om infektionssjukdomar var den vanligaste dödsorsaken förr så orsakar dege-

\footnotetext{
${ }^{1}$ År 2010 var medellivslängden 83.2 år för kvinnor och 79.1 år för män i Sverige, och av de drygt 9.4 miljoner invånare som bodde i Sverige var 1.7 miljoner 65 år eller äldre. Enligt befolkningsprognosen beräknas den sistnämnda siffran ha ökat till ungefär 2 miljoner år 2020 och till drygt 2.7 miljoner år 2060. Under år 2010 avled 90487 personer i Sverige och 71 834, knappt 80 procent av dem var 65 år eller äldre när de dog $(\mathrm{SCB}, 2012)$. Även utifrån en europeisk kontext blir alltfler i befolkningen äldre. Cirka 80 procent av dem som dör är över 65 år (Johnson, 2009, s. 660).
} 
nerativa sjukdomar flest dödsfall i dag. Det är sjukdomar som förknippas med ålderdomen och de orsakar ofta olika slags fysiska och mentala funktionsnedsättningar (Seale, 1998, s. 44). I dag dör ungefär en tredjedel av svenskarna så att säga den "snabba döden", medan de övriga dör den långsamma döden (Tännsjö, 2009, s. 14). Vi kommer således i framtiden ha fler äldre och gamla som dör den utdragna döden och det lär också ställa krav på hur vård och omsorg av äldre ska bedrivas. Därför blir det, menar bland andra äldreforskaren Rahm Hallberg, väsentligt att forska om hur äldre människor ser på döende och död, men understryker att "deras syn på döden och döendet måste förstås utifrån deras samlade livserfarenheter, värderingar och förväntningar på livet och faktorer som präglar de äldres nuvarande liv" (Rahm Hallberg, 2010, s. 87).

För att kunna bidra till utformningen och utvecklingen av vård och omsorg och palliativ vård för äldre - vilken ofta skiljer sig från den palliativa vård yngre får - och samtidigt kunna tillgodose äldres vårdbehov, behövs det kunskap om äldres syn på döende och död. Det gäller såväl äldre friska som äldre skröpliga, multisjuka och döende (Rahm Hallberg, 2004, s. 87; 2010, s. 100; se även Lloyd, et al., 2007, s. 65). Det som blir väsentligt i min studie är att undersöka vad relativt friska äldre människor har för olika föreställningar om och förhållningssätt till döende och död och hur de funderar kring det egna döendet och döden innan de kanske hamnar i en döendeprocess.

\section{Dödens position i dagens samhälle}

Går det att säga någonting om vilket utrymme eller vilken uppmärksamhet frågan om döden får i dagens samhälle. "Är det sant att vi inte talar om döden? Det sägs så, det har länge sagts, men lika länge har vi oupphörligen talat om att vi inte talar om döden" hävdar litteraturvetaren Mazzarella (SvD 120514). Det finns påtagligt divergerande uppfattningar om huruvida döden är ett ämne som synliggörs och som det talas om i dagens samhälle. Utifrån ett västeuropeiskt sammanhang talas å ena sidan sedan ett par decennier tillbaka om en "revival of death" (Walter, 1994). $\AA$ andra sidan, och i kontrast till denna uppfattning om en "revival of death", framhålls i stället att temat döden är något som är frånvarande i samhället av i dag.

Enligt den västerländska uppfattningen om en "revival of death" hålls döende och död inte längre separerade från vardagslivet på samma sätt som tidigare. Då sades döden ofta vara "undangömd" på institutioner som sjukhus och äldreboenden. Det är snarare så att döden anses ha gjort "comeback" och att den nu synliggörs i fler offentliga sammanhang än tidigare.

Döden har återigen blivit en naturlig del av livet. Det märks framför- 
allt genom att media har fått allt större betydelse i förmedlandet av döden. Det handlar om allt från seriösa till sensationella inslag om döden i media. Exempelvis kan det stå i dagstidningar att "Döden är inne igen /.../ döden är plötsligt en del av det offentliga samtalet igen /.../ och så själva trenden, 'döden chic'" (Sydsvenskan, 091102), och att "forskare har börjat ifrågasätta diagnosen död. I vissa fall har för snabba beslut fått människor att 'återuppstå från de döda'" (DN, 130603). På TV och i radio sänds dokumentärer om döende som erhåller palliativ vård i livets slutsked eller så diskuteras existentiella frågor ${ }^{2}$. En internetsökning på temat döden ger miljontals träffar. Det kan handla om alltifrån listor över antalet döda svenskar i katastrofer ${ }^{3}$ till "Hjärnkirurg chockar alla - Livet efter döden existerar"4. Ytterligare ett fenomen som börjar bli vanligt är besök på platser, utställningar och minnesmärken i världen med döden som centralt tema - "Dark tourism" (Walter, 2008, s. 325)

En allmän uppfattning i dag är att våra erfarenheter av döende och död i stor omfattning är formade av medierna, och att mediernas förmedling av döden aldrig tidigare har varit så omfattande som just $\mathrm{i}$ dag. Det är i möten med TV, radio, tidningar, böcker och internet där människor dör, döda kroppar visas upp och efterlevande sörjer som våra erfarenheter skapas kring döden (Hirdman, 2012, s. 7; jfr Seale, 1998, s. 122ff). Döden som den förmedlas via medierna innehåller ofta allt: "ett drama, ett öde och en historia, skrämmande detaljer, ett budskap som kan handla om våld, hat och galenskap, eller om försoning" (Johannisson, 2008, s. 7). En vanlig uppfattning är att medias skildringar av främmande människors döende och död utgör de mest gemensamt delade erfarenheterna av döende och död som vi har i dag. I de sammanhangen nämns ofta att medierna har övergått till att vara det nya offentliga rummet som härbärgerar döden. Teknologin har alltså fått betydelse, det vill säga, tillgång till olika TVkanaler, internet och andra sociala medier har inte enbart förändrat människans sätt att leva utan även hennes erfarenheter och förhållningssätt till döden (Hirdman, 2012, s. 7ff). Historiken Harrison påpekar att det bestående intrycket i floran av dödsrelaterad litteratur, film, etcetera, är att:

\footnotetext{
2 "Döden, döden, döden",

SVT: http://www.svtplay.se/video/1680141/del-8-av-8 ; "Annas Eviga",

SVT: http://www.svt.se/annas-eviga/ ; "Filosofiska Rummet: Döden och Existensen",

P1: http://sverigesradio.se/sida/avsnitt/3434?programid $=793$

${ }^{3}$ http://sv.wikipedia.org/wiki/Lista_\%C3\%B6ver_katastrofer_efter_antalet_d\%C3\%B6da svenskar

${ }^{4}$ http://www.dagensps.se/artiklar/2012/10/09/92735229/index.xml

${ }^{5} \mathrm{http}: / /$ www.dark-tourism.org.uk/
} 
Döden är inget man får slarva med. Döden är det mentala utropstecknet som får oss att tänka linjärt, får oss skapa egna livsberättelser med ett slut som vi inte kan se eller definiera och som därför blir så mycket mer fascinerande (Harrison, SvD, 090712).

Sociologen Walter menar att medan den medicinska expertisen utgör det praktiska verktyget för att avvärja och hålla döden borta, så har nu media ersatt religionens försök att skapa mening med döden (Walter, 2008, s. 324). Men även andra aktörer med syfte att synliggöra döden i offentliga sammanhang försöker skapa debatt om döden, nämligen begravningsbyråerna. På gator och torg står det då och då representanter från Fonus och informerar om Vita Arkivet ${ }^{6}$ och fördelarna med att fylla i detta dokument. De framhåller även sin syn på döden:

En begravning är en stark sista handling. Ett personligt farväl som ska sätta avtryck. Då finns inga "måsten", inga regler och begränsningar. I stället handlar det om vad ni vill göra. Låt hjärtat och känslan styra. Och se det som en kärleksförklaring till ett liv som slocknat. Berätta om era önskemål för oss, så gör vi allt för att uppfylla dem. Vi kallar det Nya tidens begravningar. ${ }^{7}$

Som en kontrast till uppfattningen om en "revival of death" framhåller andra i stället att döden som tema är frånvarande i dagens samhälle och något "som vi oftast håller ifrån oss med all kraft" (Rahm Hallberg, 2010, s. 88). Med andra ord, döden skapar rädsla och skräck:

I vår kultur gömmer vi döden i tystnad. Vi gör det därför att vi känner rädsla eller skräck inför det oundgängliga ödet och vi talar sällan med andra om det. Vi vill inte skrämma eller skapa en dyster stämning. Ändå tänker vi ofta på döden och förr eller senare möter vi den. Tystnaden gör det mötet svårare, mycket svårare. Större öppenhet skulle mildra mötet. Vi skulle vara bättre beredda att stödja varandra (Vestlund, 2008, s. 7).

Flera forskare menar att "döden har blivit anonym och overklig" (Nilsson, 2008, s. 16), "livet och döden finns i åtskilda sfärer i en alltmer konstruerad verklighet" och där döden har tvingats bort från "vår vardagliga erfarenhetsvärld" (Kallenberg, 2007, s. 202). Teologen och begravnings-

\footnotetext{
${ }^{6}$ Vita Arkivet är en möjlighet för dig att berätta om dina önskemål runt din egen begravning. Här kan du påverka, göra val och ha en önskan, men det är också en möjlighet att ge dina anhöriga friheten att skapa en vacker och för dem minnesvärd begravning. (http://www.fonus.se/uploads/media/VA_Blankett_2013_31maj.pdf).

${ }^{7} \mathrm{http}: / /$ www.fonusost.se/ntb/
} 
forskaren Aggedal menar att döden har svårt att ta plats i vardagslivet: "Vi har en attityd att döden inte ska få oss att stanna upp, att det är inget som vi prioriterar" (DN, 101104). Några forskare går till och med så långt att de menar att döden är något som människan överhuvudtaget inte vill vidröra, inte ens med sin egen tankeförmåga:

... vi har förpassat döden, liksom sorgen och lidandet, till ett själsligt vindsförråd som vi låser med dubbla lås; en plats dit vi ogärna beger oss och lika ogärna vidrör i något sammanhang. Snart inser man att det handlar om en förnekelse av astronomiska mått. Och som med all förnekelse omges det hela av en rad fördomar och en stark tystnad (von Malmborg \& Silfving, 2007, s. 9).

Filosofen Koestenbaum menar att den springande punkten är att människan är högst medveten om sin död, men att hon inte låtsas om den eller gör något åt den (Koestenbaum, 1984, s. 9). Det som i stället efterfrågas i dag är - faktaböcker, filmer och stora filosofiska verk - som kan bryta tystnaden, diskutera döden och återföra döden till vår vardagliga erfarenhetsvärld. Det ses som nödvändigt $\mathrm{i}$ dagen samhälle då varken närstående, kyrkan eller någon annan kan tillhandahålla forum för samtal om döden (von Malmborg \& Silfving, 2007, s. 7ff).

Denna avsaknad av samtal om döden är, enligt några författares synsätt, så markant att den genomsyrar hela samhället så till den grad att forskarna argumenterar för ett paradigmskifte för att fylla detta "tomrum" - "Om vi talar om döden, om vi förbereder den, om vi fyller den med mening, då bygger vi en ny tradition som hela samhället behöver" (Nilsson, 2008, s. 13). Etnologen Åkesson manar dock till eftertanke. Hon menar att det finns en uppsjö av handböcker och vetenskapliga texter där döende, död och sorg diskuteras, och ställer sig därför frågan: "Hur kan något som man talar så mycket om vara gömt och glömt?" (Åkesson, 1997, s. 11). Psykologen Fischler påpekar att det redan finns ett slags samtalets paradigm - där samtal och öppenhet kring svåra ämnen anses centrala för att kunna mildra dessa möten. Men hon menar att det inte alltid är den rätta vägen: "Ett missförstånd är att alla behöver prata. /.../ En föreställning om att samtal är lösningen på alla psykiska svårigheter" (Fischler, DN, 130820).

En annan aspekt, som tycks omöjliggöra en "revival of death" handlar om att dödens frånvaro i samhället ofrånkomligen hänger "ihop med att den utmanar och hotar centrala värden som tillhör det senmoderna samhället, skapandet av självidentitet, transcendens, kontroll över kroppar och sinnen och förmågan till självreflexion" (Magnússon, 2004, s. 70; se även Kallenberg, 2007, s. 203). Det finns alltså inte något utrymme för döden i samhället när det är människors självförverkande som ska priorite- 
ras, därför blir döden som ämne enbart en individuell angelägenhet, om ens det. En fällande dom över denna frånvaro av döden i samhället är: "Lever vi kanske i en epok som kommer att gå till historien med att det var då den västerländska människan förlorade förmågan att dö?" (Högerås, Barometern-OT, 131108). Det påminner i så fall starkt om hur människan kunde förhålla sig till döden på 300-talet f. kr.: "Där döden finns, finns inte vi och där vi finns, finns inte döden. Därför är döden ingenting för oss" (Epikuros).

Men om det ändå är så, att en aspekt är att dagens samhälle genomgår en "revival of death" - Vems döende och död är det då som synliggörs, offentliggörs och som det talas om? Medieforskaren Andersson menar att den spektakulära, snabba och ovanliga död, som medierna i ett övermått bidrar till att återinföra bland våra erfarenheter, får stort utrymme i dag, till skillnad från den vanliga långsamma döden. Däremot, påpekar hon, den död som förmedlas via internets bloggar bryter mot detta mönster och visar i stället en realistisk döendeprocess där den långsamma döden beskrivs. Det är ofta yngre kvinnor, men även medelålders kvinnor och män, döende i cancer, som bloggar om det egna döendet, livet och döden (Andersson, 2012, s. 188ff; se t.ex. Kristian Gidlunds blogg8). Om då synliggörandet av yngres och medelålders döende i cancer, vilket oftast anses som hemskt och orättvist, utgör en del i en "revival of death" så får däremot äldres döende och död en marginell uppmärksamhet $i$ offentlig debatt (Jönson, 2002, s. 16). Äldreforskaren Österlind menar att detta ointresse för äldres döende och död i förhållande till yngres döende och död "kan vara ett uttryck för ålderism och föreställningar om att livet vid hög ålder inte är något eftersträvansvärt" (Österlind, 2009, s. 19). En anledning till att äldres död marginaliseras, menar sociologen Howarth, är att yngre generationer inte vill befatta sig med döden, och framförallt inte med äldres död (Howarth, 1998, s. 675; se även Glaser \& Strauss, 1980). Vanligtvis förmedlas två stereotypa bilder av äldres döende och död när de äldre trots allt omnämns i offentliga sammanhang. Antingen är äldres döende och död något vackert, naturligt, okomplicerat och något som äldre skulle vara mer förberedda inför och välkomna bara för att de är äldre och har levt ett långt liv (Howarth, 1998; 2007, s. 52f; Jecker \& Schneiderman, 1994, s. 67f; Kellehear, 2007a, s. 232; Lloyd, 2004; Magnússon, 2009, s. 72). Eller så förknippas den med vanvård och en ovärdig död, ensam och isolerad på institutioner (Kellehear, 2007a, s. 210ff; Magnússon, 2009, s. 65; se även exempelvis SvD 130526). Johnson menar att det behövs en attitydförändring i samhället i förhållande till äldres döende och död - att samma värderingar och förståelse ska gälla för äldres sista tid i livet som för döende

\footnotetext{
${ }^{8} \mathrm{http}: / /$ ikroppenmin.blogspot.se/
} 
yngre:

The culturally accepted stretched life span has incorporated the marked extension of life expectancy. So there is a new norm for death, which is embedded in the collective psyche, though the normative framework has yet to permeate into any socially recognizable patterns that signify the importance and meaning of dying in later life (Johnson, 2009, s. 664).

\section{Varför studera det valda området?}

Med utgångspunkt i diskussionen ovan - om dödens position i såväl det socialgerontologiska forskningsfältet som i dagens samhälle - framkommer flera argument som talar för betydelsen av att studera vad äldre människor själva har för föreställningar om och förhållningssätt till den egna framtiden, döendet och döden.

För det första - Äldre människors senare del av livet med fokus på deras föreställningar om döende och död erhåller litet utrymme i forskningen. Dessutom är det få studier som tar utgångspunkt i en svensk social, kulturell och historisk kontext (Rahm Hallberg, 2004, s. 89; Whitaker, 2013, s. 6). Det som också gör studien utmanande är att frågor om döende och död ställs till relativt friska människor i åldrarna 70-91 år, som bor i eget boende, som på många sätt lever ett aktivt liv där föreningsliv, sociala relationer och fysisk träning ofta betonas, och som inte i någon större utsträckning är beroende av varken vård eller omsorg. Populationen utgörs av en kategori människor, vilken enligt de socialgerontologiska definitionskriterierna med största sannolikhet skulle kunna klassificeras och kategoriseras som tillhörandes "the successful agers" (Rowe \& Kahn, 1997) eller "tredje åldern" (Laslett, 1989; 1994). Med andra ord - jag har valt att studera ämnet döden med utgångspunkt från en kategori äldre människor som står en bit från såväl sjukdom, vårdberoende som döende och död och som i det avseendet motsvarar den rådande definitionen på "tredje åldern". Och varför skulle man inte kunna sammanföra tredjeålderntemat med ämnet döden? De flesta intervjuade har sett både faroch morföräldragenerationen och föräldragenerationen försvinna. $\mathrm{Nu}$ upplever de att den egna generationen gallras ur alltmer. Med denna insikt om att livet inte varar för evigt och att den kvarvarande tiden krymper - Betyder det att frågan om döden aktualiseras för de intervjuade? Sett ur ett tredje åldersperspektiv kan man då ställa frågan - Varför ska de intervjuade fundera och samtala om döden, när de varken är skröpliga, sjuka eller döende? Men samtidigt, varför skulle de inte tänka och prata om döden? Även om människor i alla åldrar kan tänkas vilja prata om döden är det rimligt, menar forskare, att anta att det är frågor som särskilt aktualiseras i livets senare skeden (Howarth, 1998; Wong, 2000). Här, i 
diskussionen om "tredje åldern", är det viktigt att understryka att de intervjuade också befinner sig i olika åldrar - mellan 70-91 år. Det är ett förhållande som skulle kunna ha betydelse för hur man förhåller sig till döden. Något som också har framkommit i de intervjuades berättelser. Några av de riktigt gamla menade att de teoretiskt sett snart skulle dö och "att det bara fanns en bit utförsbacke kvar" populationen, däremot, nämnde att de faktiskt kanske kunde ha åtminstone 20 år kvar att leva. Det innebär att de intervjuade har vuxit upp under olika årtionden, mellan 1920- och 1940-talen, vilket också kan ha betydelse för hur man ser på döden. Det är ett viktigt förhållande att vara medveten om och att också beakta den kronologiska åldern fortsättningsvis i studien. Avhandlingen tar alltså upp frågor, vilka sällan har blivit problematiserade i den forskning som handlar om "tredje åldern".

För det andra - Flera forskare menar att det är iögonfallande hur den socialgerontologiska forskning som anlägger ett livsloppsperspektiv sällan beaktar äldre människors funderingar på den egna framtiden (Jeppsson Grassman \& Whitaker, 2013). Äldreforskarna Nilsson, Sarvimäki och Ekman konstaterar också att forskning om äldres framtid förbises:

As the life that has passed is so much longer than the remaining years in advanced age, it is natural that the major amount of research on older people should focus on the time that has passed. In old age, life experiences will make up a frame of reference against which the old people will evaluate their life past and present. /.../ Regarding theories of aging, circumstances are similar. The importance of the individual's past life has been emphasized and gained most interest, while considerations about the future in old age are scarce and less elaborated (Nilsson, Sarvimäki \& Ekman, 2003, s. 346).

Den övervägande delen av de studier som anlägger ett livsloppsperspektiv tycks alltså betona de äldres livshistoria och nutid i stället för deras framtid. Mot bakgrund av detta faktum bör därför frågan ställas - Varför är de äldres framtid intressant att diskutera, och framförallt i förhållande till begreppet döden? Människors funderingar och agerande inför framtiden kan, enligt Feifel, vara mer influerade av döden än vad man tror:

It has been said that we may learn looking backward - we live looking forward. A person's thinking and behavior may be influenced more than we recognize by his views, hopes and fears concerning the nature and meaning of death (Feifel, 1959, s. 116).

\footnotetext{
${ }^{9}$ Citat kommer från en av intervjupersonerna.
} 
Det sägs också att ett vanligt drag bland människor handlar om en önskan att få fortsätta att leva (Drolet, 1990, s. 148). Dessutom tycks en central egenskap hos mänskligt tänkande vara att fundera på och att agera inför framtiden (Nurmi, 2005, s. 31). Samtidigt visar tidigare forskning att äldre människor skiftar tidsperspektiv med åldern, det vill säga, de omformulerar planer och ambitioner, och blir samtidigt mer nutidorienterade (Tomer, 2000a, s. xiv; se även Carstensen, Isaacowitz \& Charles, 1999). Min avhandling utgår från ett livsloppsperspektiv, vilket innebär att förståelsen för de intervjuades tankar på och föreställningar om den egna framtiden, döende och död baseras på hela deras dynamiska livslopp - dåtid, nutid och framtid - och i samspel med den historiska tid som de är en del av.

För det tredje - Om argumenten ovan till stora delar har handlat om värdet av att studera äldres framtid, döende och död utifrån ett par socialgerontologiska perspektiv som tidigare forskning försummat, så finns det också flera allmängiltiga argument för en sådan forskningsinriktning. Ålderdomen är den fas av livet då man förväntas dö. Därom vittnar statistiken - att det långsamma döendet blir allt vanligare och att de flesta $\mathrm{i}$ dag dör i hög ålder. Det tas också för givet att man bör tänka på döden i ålderdomen - "döden tillåter oss att skänka vårt liv mening retroaktivt, en användbar tanke för äldre människor" (Koestenbaum, 1984, s. 20). Det sägs att döden skulle vara något äldre människor borde vara mer förberedda inför, därför att de är äldre och har levt ett långt liv (Howarth, 1998; 2007). Andra anser däremot att döden är ett ämne man har anledning att fundera över först när man är skröplig eller döende: "It has been suggested that if a person does not have a serious medical condition, there was 'probably no reason to think about end-of-life issues'" (Lloyd-Williams et al., 2007, s. 65). Hur ställer sig då äldre människor till de här ståndpunkterna? Är äldre intresserade av att samtala med andra människor om döden, och finns det något behov av att prata? Forskare anser att varken familjekretsen, vänkretsen eller kyrkan längre utgör någon plattform för samtal om döden. De efterlyser i stället ett slags paradigmskifte för att föra fram samtalet som lösningen på "tomrummet" kring döden (von Malmborg \& Silfving, 2007, s. 7ff). Andra menar i stället att vi lever i ett samtalets paradigm där öppenhet och samtal anses vara lösningen för att kunna hantera svåra ämnen, men att samtal inte alltid behöver vara rätta vägen (Fischler, DN, 130820). Hur ställer sig äldre människor till att prata om döden i ett samhälle där det sägs att människan är högst medveten om sin död, men där hon varken låtsas om den eller gör någonting åt den? Där döden som ämne enbart blir till en individuell angelägenhet, om ens det, och där det generella förhållningssättet till döden också är - "others die, I do not" (Elias, 1985, s. 1). 
Oavsett var i livsloppet människan befinner sig, oavsett funderingar på eller prat om döden så anses döden vara ett laddat ämne, och då framförallt när den rör närståendes död och den egna döden:

However death, in particular death of people closer to us, as well as our own personal death, is problematic. While objectively we "understand" death, subjectively we tend to reject it and to be afraid of it. It is this tension between our objective understanding of death and the subjective problem that feeds the development of death-related attitudes (Tomer, 2000b, s. 88).

Den tidigare diskussionen om dödens position i både det socialgerontologiska forskningsfältet och i dagens samhälle, samt de ovan nämnda argumenten har lett fram till följande syfte och forskningsfrågor.

\section{Syfte och forskningsfrågor}

Det övergripande syftet med studien är att utforska äldre människors föreställningar om och förhållningssätt till den egna framtiden, döendet och döden. Studien tar sin utgångspunkt i de äldres egna erfarenheter, tankar och föreställningar om den senare delen av livet. Att dessutom anlägga ett livsloppsperspektiv innebär inte enbart att fokus har lagts på den senare delen av äldres liv. För att kunna förstå de äldres tankar kring dessa teman har hela deras livslopp beaktats. En kvalitativ metodansats har tillämpats. Studien bygger på intervjuer med 27 äldre kvinnor och män i åldrarna 70-91 år som bor i Sverige, vilka har levt ett långt liv, men vars framtid blir alltmer begränsad på grund av ålder. Intervjupersonerna, som alla bor i ordinärt boende och betraktar sig själva som relativt friska, har givits möjlighet att berätta, minnas och reflektera över såväl sin livshistoria och sitt åldrande som kring sin framtid, döende och död. Följande forskningsfrågor kom att undersökas:

- Hur beskriver äldre människor sina tidigare erfarenheter av döende och död?

- Hur ser äldre människor på sitt eget döende och på sin egen död?

- Vilka erfarenheter har äldre människor av möten med döende och död i det vardagliga livet?

- Vilka föreställningar har äldre människor kring vad som kommer att ske efter den egna döden?

- Hur ser äldre människor på sin framtid och på den tid som är kvar?

De kunskapsvinster projektet kan förväntas ge är av både samhällelig och vetenskaplig karaktär inom ett område som hittills är svagt beforskat. Här 
kan studiens resultat bidra med kunskap som också har praktisk relevans för socialt arbete och socialtjänstens verksamheter, inte minst för äldreomsorgen och dess utformning och utveckling av vård och omsorg för äldre, men även för den palliativa vården för äldre. Nyttan i ett vidare perspektiv består $\mathrm{i}$ att studiens resultat kan bidra till att uppmärksamma äldres situation i samhället i allmänhet, och de äldres funderingar kring framtid, döende och död i synnerhet. Dessutom kan studien ge ökad kunskap om och större förståelse för de särskilda behov som äldre människor kan ha i den senare delen av livet. Den vetenskapliga kunskapsvinsten består i att resultaten bör kunna bidra till både det socialgerontologiska och det tanatologiska fältet genom en ökad empirisk och teoretisk förståelse när det gäller äldres tankar om framtid, döende och död. Studien kan även bidra med kunskap som har relevans för forskning kring livslopp, kritisk gerontologi och psykologi.

\section{Avhandlingens disposition}

Avhandlingen består av nio kapitel. I detta första kapitel - Äldres framtid, döende och död - gavs en kort ingress angående problemområdets vetenskapliga såväl som samhälleliga karaktär samt argument som talar för betydelsen av studien. Vidare presenterades syfte och forskningsfrågor samt en redogörelse för studiens disposition.

Kapitel 2 - Tidigare forskning och teoretiskt ramverk - ger en översikt av tidigare forskning om äldres framtid, döende och död, samt presenteras teoretiska och begreppsliga utgångspunkter. Förutom en teoretisering av bland annat begreppen tid, tredje åldern, döende och död, problematiseras också det för studien så centrala livsloppsperspektivet.

Kapitel 3 - Metoder, material och genomförande - presenterar en redogörelse för studiens metodologiska genomförande. Inledningsvis fokuseras några metodologiska utgångspunkter och ställningstaganden, därefter följer en diskussion om hur studien har genomförts - urvalsprocess, datainsamling, tolknings- och analysprocess, etiska övervägande, samt studiens trovärdighet. Kapitlet avslutas med en kortfattad presentation av intervjupersonerna som ingår i studien.

Kapitel 4-Möten med döende och död genom livet - är det första av fem kapitel som presenterar resultat och analys. Det här kapitlet fokuserar intervjupersonernas möten med döende och död genom livet. Vilka erfarenheter har de intervjuade av döende och död och på vilka sätt har dessa erfarenheter varit med och format intervjupersonerna genom livet?

Kapitel 5 - Tankar i vardagen på döende och död - handlar om intervjupersonernas tankar i vardagen på döende och död. Funderar de intervjuade överhuvudtaget på döende och död i vardagen? Var och i vilka vardagliga sammanhang och situationer uppstår tankar på döende och död? 
Vad handlar dessa funderingar om?

Kapitel 6 - Samtal om döende och död - handlar om intervjupersonernas samtal om döende och död i sociala och mellanmänskliga sammanhang. Vilka erfarenheter har de intervjuade av att prata med någon om döden i vardagen? Vad är det om döden som avhandlas vid dessa sociala sammanhang och hur reagerar omgivningen på denna typ av samtal?

Kapitel 7 - Efter döden - handlar om de intervjuades funderingar och resonemang om vad man tror händer efter döden. Är det viktigt att deras begravning besöks av någon? Var vill de bli begravda? På vilka sätt vill de att deras omgivning ska minnas dem? Vad tror de intervjuade kommer att hända efter deras död?

Kapitel 8 - Tid kvar - handlar om de intervjuades framtid. Hur ser de på sin framtid och på den tid som är kvar? Är det viktigt att fundera på den egna framtiden?

I Kapitel 9 - Sammanfattande resultat och slutdiskussion - presenteras en sammanfattning och en avslutande diskussion kring studiens resultat. 



\section{KAPITEL 2}

\section{Tidigare forskning och teoretiskt ramverk}

I det föregående kapitlet diskuterade jag dödens position i det socialgerontologiska forskningsfältet och i dagens samhälle och presenterade studiens syfte och forskningsfrågor samt ett antal argument för studiens värde. Det här kapitlet består av två delar. I den första delen redogör jag för tidigare forskning om äldre människors framtid, döende och död som har varit av relevans för min undersökning. I den andra delen diskuterar jag mitt val av teoretiskt ramverk som har varit av betydelse för studien.

\section{Forskningsöversikt}

I avsnittet fokuserar jag inledningsvis på för studien relevant litteratur om äldre människors framtid, döende och död. En litteratursökning gjordes för att få överblick över vad som skrivits tidigare, forskningsfrågor som ställts och metodval som gjorts. Vid litteratursökningen utgick jag från såväl tidigare publicerade litteratturöversikter (se Nurmi, 2005; RahmHallberg, 2004; Socialstyrelsen 2004; 2007; Whitaker, 2004) som sökningar i databasen Scopus. Utöver en orientering i forskningsfältet visade litteratursökningen också på vissa luckor i det aktuella kunskapsläget.

Vid genomgången nedan av tidigare forskning har jag valt att redovisa den forskning som anlagt ett "ovanifrånperspektiv" på äldres framtid, döende och död, samt den forskning som fokuserat äldre människors egna perspektiv på dessa ämnen var för sig. Valet gjordes för att få en bild av hur tidigare forskning har behandlat ämnena, men också för att kunna urskilja kontraster mellan hur andra människor ser på äldres framtid, döende och död, respektive hur äldre människor ser på sin egen framtid, döende och död. Översikten av kunskapsläget har inte enbart haft betydelse för studiens forskningsbakgrund. Jag har även, i linje med min abduktiva och hermeneutiska metodansats (se kapitel 3), använt mig av denna litteratur i analysen av empiri för att jämföra och kontrastera mina resultat mot tidigare forskning. Dessutom har jag under arbetsprocessens gång gjort nya sökningar i databasen Scopus för att uppdatera kunskapsläget och har på det viset tillfört "nya" aspekter till materialet i studien. 


\section{Andras syn påäldres framtid}

Psykologen Nurmi (2005) menar, med utgångspunkt i en västerländsk kontext, att människans funderingar på framtiden och hennes agerande inför densamma utgör centrala inslag i människans väsen. Med andra ord, människan tänker vanligtvis på vad som kommer att hända i framtiden, hon har ofta åsikter om framtiden och hon planerar och sätter upp mål inför framtiden. Hon lägger också ner energi och kraft på att kunna realisera de uppsatta framtida målen. En sådan orientering inför framtiden uppstår dock inte i ett vakuum. Den vilar på tidigare erfarenheter och minnen såväl som på motivation, intressen, värderingar, känslor, attityder, etcetera (jfr Wasling, 2013). Dessutom, menar Nurmi, kan människans förhållningssätt till framtiden förändras beroende på var hon befinner sig $\mathrm{i}$ livsloppet. Det vill säga, olika faser i livet karaktäriseras utifrån olika socio-kulturella åldersstrukturer/normer, vilket kan påverka sättet att se på framtiden och får sålunda betydelse för människans framtidsorientering - så kallade "road maps for human lives" (Nurmi refererar till Hägestadt \& Neugarten [1985], 2005, s. 35).

Forskningen, om människors orientering inför framtiden utifrån olika åldersperspektiv, är emellertid svagt utvecklad och åldersmässigt i obalans. De flesta studier handlar om ungdomars funderingar på och agerande inför framtiden. En anledning är att under den här livsfasen förväntas ungdomarna ställas inför flera viktiga val inför det framtida vuxenlivet som exempelvis utbildning och arbetsmarknad. Få studier handlar om barns framtidsorientering. I den livsfasen är barn beroende av sina föräldrar och förväntas vara en del av deras framtidsorientering. Studiet av vuxnas funderingar och agerande inför framtiden - framförallt äldre vuxna mellan 70-100 år - är även det underbeforskat (Nurmi, 2005, s. 31ff).

Det tycks finnas flera skäl till detta ointresse för äldres framtid och varför det finns så få studier om äldre människors funderingar på framtiden. Av betydelse är kanske samhällets syn på äldres framtid. I vår tid, som brukar beskrivas som starkt framtidsorienterad, anses ofta produktivitet, effektivitet, självständighet, oberoende och ungdomlighet fungera som ideal. Detta får konsekvenser för äldre människor då de varken anses kunna leva upp till de nämnda idealen eller anses ha några framtidsutsikter värda att satsa resurser på (Tornstam, 2005, s. 85f). Äldre människor karakteriseras på sätt och vis som "has beens", de har visserligen levt ett långt liv men de är föredettingar och framtiden är inte lägre deras arena (Krekula, Närvänen \& Näsman, 2005, s. 81ff). Efter att ha uppnått en viss ålder betraktas sålunda äldre människors förmågor som nästan färdigförbrukade. De anses inte längre kunna bidra till samhällsutvecklingen varken socialt, ekonomiskt, akademiskt eller kulturellt (Jecker \& 
Schneiderman, 1994, s. 67). Framtiden tillhör de yngre generationerna. Barn och ungdomar anses kunna knyta samman dåtid och nutid med framtid, på såväl familje- som på samhällsplanet, genom att utgöra en slags länk mellan generationerna (Jecker \& Schneiderman, 1994, s. 67f; Söderlind \& Engwall, 2008, s. 23).

Denna mindre välvilliga syn på äldre människors framtid går också att urskilja i den forskning där äldres framtid ofta beskrivs utifrån - ett "ovanifrånperspektiv". I början av 1980-talet utkom ett antal forskningsrapporter - Äldre $i$ samhället förr, nu och i framtiden (Tornstam, Odén \& Svanborg, 1982; 1983) och Tid för omsorg (Lagergren, 1983) - som diskuterar äldre människor utifrån ett framtidsperspektiv, men utan att i någon större utsträckning ta hänsyn till äldres personliga perspektiv. De prognoser som forskarna presenterar om äldres framtid i dessa studier är inte sällan formulerade i negativa termer, där kriser, beroende och förluster har en dominerande plats i texterna - en slags demografisk alarmism. Äldre människor gestaltas här som "kommande samhällsproblem" snarare än som aktörer i samhällsutvecklingen. Det centrala blir att finna lösningar på deras problem - att på olika vis få framtidens äldre människor mindre beroende av exempelvis vård och omsorg.

Verk av senare datum är - The futures of old age (Vincent, Phillipson \& Downs, 2006) och Senior 2005 (SOU 2002:29; SOU 2003:91). Det förstnämnda är en antologi med syfte att undersöka hur framtiden kan komma att gestaltas för äldre människor de närmaste 30 åren, med betoning på framtid i pluralis. Äldres framtid är inte längre endast likriktad, den är mångtydig. Äldres framtid kan med andra ord förutspås bli något annat, och mer mångfacetterat, än bara ett kommande samhällsproblem. De teman som får utrymme och diskuteras utifrån ett framtidsperspektiv är exempelvis äldres boende, äldre i en globaliserad värld, äldres hälsa och välbefinnande och äldres pensionering. Den parlamentariska utredningen Senior 2005 är också ett exempel på andras syn på äldres framtid. Betänkandet syftar till att skapa förutsättningar för en långsiktig utveckling av äldrepolitiken, att finna lösningar på utmaningarna med en åldrande befolkning. Här fokuseras på många sätt det aktiva åldrandet utifrån ett tredjeåldern perspektiv medan fjärdeåldern perspektivet nästan inte alls får någon uppmärksamhet (SOU 20002:29; SOU 2003:91). Det är inte svårt att se vissa paralleller i rapporterna Äldre $i$ samhället förr, nu och i framtiden, Tid för omsorg, The futures of old age och Senior 2005. Flera av de ämnen som problematiseras i de tidigare verken är också centrala i 2000-talets framtidsperspektiv kring äldre människor. I samtliga verk är avsaknaden av temat äldres döende och död emellertid påfallande. 


\section{Äldres syn på den egna framtiden}

Forskning om äldre relativt friska människor och deras syn på den egna framtiden är begränsad (Nurmi, 2005). Några av de studier som fokuserar äldres orientering inför framtiden, och vilka Nurmi (2005) hänvisar till i sin forskningsöversikt ${ }^{10}$, handlar om vad äldre har för tankar inför framtiden - deras planer, mål, drömmar. Om tankarna på framtiden skiljer sig från de man hade tidigare i livet, varför tankemönstren förändras, samt på vilka sätt äldre värdesätter sin framtid. Forskare menar att det sker en förändring i synen på den egna framtiden bland äldre, det vill säga, annat blir viktigare att fundera över i ålderdomen än under tidigare livsfaser. I högre grad är äldres framtidstankar relaterade till hälsa, sociala relationer, religion, identitet och omsorg om andra. En anledning till att äldre förändrar sin orientering inför framtiden är bland annat att den upplevs som mer begränsad än tidigare i livet. Nurmi menar att denna förändring i äldres syn på den egna framtiden delvis knyter an till "road maps for human lives" (Nurmi, 2005, s. 31ff). Sett till tidigare forskning verkar teman som döende och död förekomma i mycket liten utsträckning. Få studier tycks undersöka hur långt in i framtiden äldres tankar, planer och mål sträcker sig.

Studier som problematiserar människors egna funderingar på framtiden är bland annat - The meaning of the future for the oldest old, (Nilsson, Sarvimäki \& Ekman, 2003) och Hopes, fears and expectations about the future: what do older people's stories tell us about active ageing? (Clarke \& Warrant, 2007). Den metodologiska ansatsen i dessa studier är kvalitativ med longitudinella inslag. Äldre människor, i åldrarna 80-96 och 60-96 år, har intervjuats vid ett antal tillfällen utifrån ett livsloppsperspektiv: "A clearer understanding if what people want in the present can be gained if their lives are seen in the context of their past and if we listen to what they say, or do not say, about the future" (Clarke \& Warrant, 2007, s. 482f). Nilsson, Sarvimäki och Ekmans studie tar sin utgångspunkt i äldre människors filosofiska reflexioner kring den egna framtiden. Clarke och Warrants studie utgår från begreppet "active ageing", där man menar att begreppet kan ha andra innebörder för äldres framtid än att det nödvändigtvis måste associeras till hälsa, mobilitet och socialt samspel - begrepp som vanligtvis förknippas med "tredje åldern". Det kan exempelvis handla om att planera inför döden.

Ett par resultat som betonas i studierna är att tankar på framtiden på varierande vis kan utgöra en del av äldres vardag. Antingen ses framtiden an med tillförsikt, med hopp att få leva länge och kunna uppleva så

\footnotetext{
${ }^{10}$ Cross \& Markus (1991), Smith \& Freund (2002), Takkinen \& Ruoppila (2001), Lang \& Carstensen (2002).
} 
mycket som möjligt den återstående tiden, eller så får framtiden komma som den kommer eller så innebär mötet med framtiden någonting negativt som anses poänglöst att ödsla tid på (jfr Erikson, Erikson \& Kivnick, 1986; Gunnarsson, 2009a; 2009b). Studierna visar också att äldre människor parallellt med sin rädsla inför en framtid som kanske innebär skröplighet och beroende, kan önska sig ett långt liv och se fram mot kommande begivenheter. Det framkommer också att äldres syn på den egna framtiden överlag är mer positiv än vad tidigare forskning har visat. Sammanfattningsvis poängteras i studierna att äldre människor funderar på framtiden och anser sig ha en framtid - äldre betonar både ett nutidsorienterat tidsperspektiv och ett vidsträckt framtidsperspektiv. Resultaten skiljer sig en del från tidigare forskning som i stället betonar att människor ofta skiftar tidsperspektiv med åldern - att äldre människor, vars kommande tid alltmer krymper, planerar mindre inför framtiden och blir mer nutidsorienterade (Carstensen, Isaacowitz, \& Charles, 1999, s. 178). De finner dessutom inte någon större mening med framtida mål och drömmar, de tar snarare en dag i sänder (Brandstädter, Wentura \& Greve, 1993; Ågren, 1998). Utrymme i texterna får även äldres funderingar på döende och död. Döden var inte något man frågade deltagarna om, den kom till uttryck i fraser som: "living on borrowed time", "we're all born to die", and "if we live longer", "but none seemed preoccupied with death" (Clarke \& Warrant, 2007, s. 476; se även Gunnarsson, 2009a; 2009b; 2013; Nilsson, Sarvimäki \& Ekman, 2003).

\section{Andras syn på äldres döende och död}

En rik internationell forskning förekommer om döende och död rent allmänt sett. Lloyd menar att det går att identifiera ett antal trender i denna dödsforskning generellt - "age at death", "causes of death", "place of death", "good death" och "in end-of-life care" (Lloyd, 2010, s. 618). I ett par studier från 2000-talet konstaterar forskare (Socialstyrelsen 2004; 2007; jfr Rahm-Hallberg, 2004; Whitaker, 2004) dock att väldigt få studier fokuserar äldres döende och död, och få av dem handlar om de äldres egna funderingar kring dessa ämnen. I stället handlar studierna ofta om yngres döende och död, yngre cancersjuka, anhörigas perspektiv på döende familjemedlemmar, vårdpersonalens perspektiv på döende och död, samt om omvård i livets slut och palliativ vård. De studier som fokuserar just äldres döende och död kommer ofta från USA och Kanada, vars förhållanden - kulturellt, socialt och historiskt - skiljer sig en del från europeiska förhållanden, något som är väsentligt att notera. Flertalet av studierna handlar också om äldre människor som är sjuka och döende, om dem som bor och även dör på institutioner (Rahm Hallberg, 2004, s. 87ff, 99; se även Andersson, 2007; Magnússon, 1996; Whitaker, 2004; Österlind, 2009). Här, 
menar forskare, är det viktigt att poängtera att det kan föreligga väsentliga skillnader mellan friska äldre och döende äldre och deras syn på döende och död (Rahm Hallberg, 2004, s. 88).

Även om äldre människor sällan själva får komma till tals i forskningen kring ämnen som döende och död, så tycks ändå den generella bilden av äldres döende och död vara motsägelsefull. Å ena sidan anses äldres döende och död vara något vackert, naturligt, okomplicerat och något som äldre är mer förberedda inför bara för att de är äldre och har levt ett långt liv med erfarenheter av döden:

There is an assumption in western societies that death in old age is not only 'natural' but also 'easy' [...] - an event which loses its frightening character as the individual becomes older. /.../ Indeed, it may be that the natural and easy death in old age is a construction of younger adults. In relative youth, many assume that they will most likely live until old age. Alongside the expectation of a deferred death comes an illusion that, being so distant, it is probably not unpleasant (Howarth, 1998, s. 673, 687; se även Howarth, 2007, s. 52f; Jecker \& Schneiderman, 1994, s. 67f; Kellehear, 2007a, s. 232; Lloyd, 2004; Magnússon, 2009, s. 72).

Å andra sidan förknippas äldre människors döende och död inte sällan med vanvård och den fula döden på institutioner där man dör ensam och isolerad (Kellehear, 2007a, s. 210ff; Magnússon, 2009, s. 65; se även exempelvis SvD 130526). Dessutom kontrasterar man ofta äldres döende och död med yngres döende och död, vars död anses mer traumatisk och som alltid inträffar vid fel tidpunkt i livsloppet (Howarth, 1998, s. 673). Samtidigt verkar det finnas synsätt som handlar om att yngres döende och död kan generaliseras att gälla även äldres döende och död, att det därför inte heller behövs någon större allmän kunskap om äldres döende och död i form av ett synliggörande:

Research findings from younger people cannot easily be generalized to older people, since death and dying most likely take on a different meaning earlier in life. Also, the view of death and dying may differ between younger old, old and very old people, because they are at different point in their life span (Rahm Hallberg, 2004, s. 87).

\section{Äldres syn på det egna döendet och döden}

Studier som däremot fokuserar äldres föreställningar om och förhållningssätt till döende och död är bland annat - 'Just live for today'. Living, caring, ageing and dying, (Howarth, 1998), och The end of life: A qualitative study of the perception of people over the age of 80 on issues surrounding death and dying (Lloyd-Williams et al., 2007). Den förstnämnda studien har en longitudi- 
nell ansats där människor 75 år eller äldre intervjuades vid ett antal tillfällen. I den andra studien genomfördes intervjuer med människor 80 år eller äldre vid endast ett tillfälle. Utifrån sina resultat konstaterar Howarth att flertalet intervjupersoner var "'attached' to life and spent little time contemplating their own death" (Howarth, 1998, s. 676; jfr Gunnarsson, 2009a; 2009b; 2013). Enligt Rahm Hallberg är det få studier som uppmärksammar huruvida äldre människor överhuvudtaget tänker på döden eller inte (Rahm Hallberg, 2004, s. 99). I en brittisk studie om äldres förhållningssätt till döende och död, baserad på 125 människor i åldrarna 81-96 år, där 3 av 4 levde i ordinärt boende, svarade cirka var fjärde individ att man aldrig tänker på döden. Drygt 66 procent tänker då och då medan drygt 10 procent påstod sig ofta tänka på döden. Här är det dock otydligt om det är den egna döden, andras död eller döden som fenomen som avses. Motsvarande siffror rörande döendet visade att var tredje person funderade på döendet medan alltså 2 av 3 inte funderade alls. Endast 10 procent oroade sig för det egna döendet (Rao et al., 1997, s. 216). När äldre relativt friska människor, 80 år eller äldre, väl funderar på döden anser de att döden inte är så hemsk och skrämmande. Däremot handlar funderingar på döendet ofta om rädslan att bli liggande länge och dö en långsam död (Lloyd-Williams et al., 2007, s. 62f).

I psykologen Cicirellis forskning framkommer att "participants insisted that they simply never thought of death and consequently were not worried or afraid of it". Han anser det särskilt "puzzling when taken in conjunction with their expectations of having only a limited number of years left to live" (Cicirelli, 2006, s. 357). En alltmer krympande kvarvarande tid tycks förpliktiga att man som äldre ska eller bör fundera på den egna döden. Cicirelli menar att en anledning till att äldre inte funderar på döden kan bero på en stark försvarsmekanism hos individen, där varje tillstymmelse till tankar på döende och död förnekas eller förträngs. Cicirelli ser det som en möjlig förklaring, men som han säger, det förklarar inte "why older adults who don't want to think about death would voluntarily take part in a study in which they were to be interviewed extensively about death" (Cicirelli, 2006, s. 357). Han menar också att en annan anledning till att äldre människor inte funderar så mycket har att göra med:

That those who have less fear of death have developed a mature philosophical approach to it. /.../ to overcome the fear of death, individuals need to come to terms with the inevitable reality of death as part of the natural cycle of life, first cognitively and then affectively (Cicirelli, 2006, s. 357).

Andra resultat som betonas i studierna ovan är att äldre skildrar "den goda döden" som en död med ett snabbt förlopp och med ett minimum av 
fysisk och mental smärta. Viktigt är också att i döendesituationen kunna bevara sin självrespekt och värdighet (Howarth, 1998). Några äldre nämner att förloppet inte får vara för snabbt, man vill ha tid att larma anhöriga och inte bli liggande död utan att någon vet om det (Lloyd-Williams et al., 2007). En annan aspekt på den goda döden är att den egna döden blir mer meningsfull då man har haft möjlighet att se barn och barnbarn växa upp (Howarth, 1998). I detta fall framkom en accepterande inställning till döden, den är

oundviklig och fullbordade livsloppet. Tankar om tiden som band samman generationer, det egna livet, nuet och framtiden var vanligt förekommande. Detta livsloppsperspektiv innebar att livet "bands samman", fullbordades. Det kom till uttryck i termer av ett slags kontinuitet, inte bara omfattandes det egna livet utan även ens förfäder och ens avkomma (Rahm Halberg, 2010, s. 91).

Den onda döden däremot anses vara den död som är utdragen, smärtsam, ovärdig, och som också medför ett beroende av anhöriga och vårdpersonal (Howarth, 1998; Lloyd-Williams et al., 2007).

Att kunna påverka och ha en viss möjlighet till kontroll vid en eventuell svår dödlig sjukdom är en annan aspekt som de intervjuade diskuterar, och där begreppet euthanasia nämns som ett exempel på en möjlighet till kontroll i en döendeprocess (Howarth, 1998; Lloyd-Williams et al., 2007). En annan aspekt på begreppet kontroll, som de äldre resonerar om, är att i förväg kunna berätta hur man vill ha det i livets slutskede, exempelvis att bo hemma så länge som möjligt och att man accepterar organdonation (Lloyd-Williams et al., 2007). Begravningsförberedelser är även det ett tema som de äldre uppehåller sig vid, ett tema som kanske äldre har större möjlighet att kontrollera än den kontroll som äldre säger sig vilja ha vid en eventuell framtida döendeprocess (Howarth, 1998). Att ta beslut kring den egna begravningen minimerar även bördan för efterlevande att fatta svåra beslut (Lloyd-Williams et al., 2007). Rahm Hallberg menar, utifrån sin forskning, att äldre människor i större utsträckning förbereder sig inför sin egen död än vad som är fallet inför sitt eget döende. Hon anser detta anmärkningsvärt "eftersom det är döendet som tycks mest förknippat med ångest och farhågor om lidande och existentiell smärta. Det kan också vara förklaringen till varför man inte förbereder sig, det vill säga, man undviker det som är mest oroväckande och ångestfyllt" (Rahm Hallberg, 2010, s. 101).

Ett resultat som Lloyd-Williams et al. betonar som viktigt i studien är att ämnena döende och död har betydelse för äldre människor, och att äldre människor inte enbart behöver vara sjuka eller skröpliga för att tänka på döden (Lloyd-Williams et al., 2007, s. 65; se även McCoy et al., 
2000, s. 37). Howarth understryker att döende och död inte nödvändigtvis behöver utgöra ett betydande inslag i äldre människors liv. Döden måste heller inte vara mindre skrämmande bara för att man har åldrats. Något som är den vanliga föreställningen om äldres förhållande till döden - att den skulle vara okomplicerad och naturlig. Dessutom hävdar hon, äldre människor - som levt ett liv med ringa erfarenheter av döende och död och som aldrig har funderat eller pratat om döden - kan ställas inför det faktum att de inte "vet hur man dör". Vissa äldre anser det opassande att ens tänka på den egna döden vare sig vid 65, 75 eller 85 års ålder. Om då tankar kring döende och död hela tiden skjuts på framtiden, och man inte tar sig tid att reflektera kring dessa teman kan det också få konsekvenser, det vill säga man blir lämnad att själv ta itu med den egna rädslan och oron inför döden (Howarth, 1998, s. 686f). Även Cicirelli poängterar att många äldre saknar erfarenheter av döende och död - en brist på "kunskap" som kan få konsekvenser:

Most of the older adults we studied seemed to have an unrealistic understanding of the dying process, and consequently would be unable to make any realistic preparation for it. Such a lack of knowledge in itself may make dying more difficult for them (Cicirelli, 2006, s. 346).

Howarths och Cicirellis resultat går lite på tvärs mot annan forskning. I antologin Death attitudes and the older adult framhålls bland annat att äldres dödsångest generellt sjunker med åldern. En förklaring kan vara "that older adults find in themselves the resources necessary to deal more effectively with death anxiety than younger adults" (Tomer, Eliason \& Smith, 2000, s. 109). Även Rahm Hallberg, vars forskning tar sin utgångspunkt i en svensk kontext, framhåller att "med stigande ålder blir döden en mera medveten del av livet och vardagen" och samtidigt något att reflektera över, och därför "kommer inte [heller] döendet och döden som någon överraskning för äldre personer" (Rahm Hallberg, 2010, s. 88, 99; 2004, s. 87). Även psykologen Aiken menar:

"that the elderly are more likely to see themselves as having had their day and to view death in old age as only fair" and that older people are better able to cope with the forthcoming death, partly because of their life experiences, their failing health and the loss of people close to them (Aiken [1995] i Rahm Hallberg, 2004, s. 88).

Det finns alltså en riktning i den sistnämnda forskningen som pekar på att äldre människor ofta börjar fundera på den kvarvarande tiden och den ofrånkomliga döden. Men också att detta funderande leder till förändrade rutiner, beteendemönster och syn på vardagen och framtiden (Giordano, 
2000, s. ix).

Slutligen, Lloyd-Williams et al. betonar - i polemik med tidigare forskningsresultat att relativt friska äldre skulle vara ovilliga att prata öppet om sina tankar och idéer om det egna döendet och döden - att äldre människor i deras studie var tillmötesgående och ville samtala med sin omgivning (Lloyd-Williams et al., 2007, s. 65; se även Rao el al., 1997, s. 219). Fenomenet uppmärksammas även av Rahm Hallberg i hennes litteraturgenomgång - dels en vilja bland äldre att föra ett öppet samtal med forskarna om döden, dels att de i någon mån samtalar med sin omgivning om döden - ett sätt att kanske främja en känsla av sammanhang och identitet (Rahm Hallberg, 2004, s. 87ff).

Mycket av det som genomsyrar forskningen om äldres döende och död tycks alltså handla om att - när äldre människor har egna erfarenheter, inre resurser och "kunskap" om döende och död, så bör det underlätta och vägleda dem genom den sista delen av livet, eller som Cicirelli skriver:

Personal meanings of death help guide the individual's lifestyle, which includes preparations for death and reactions to it when it occurs (Cicirelli, 2006, s. 342).

Att levandegöra döden i vardagen, men även att ha erfarenheter av döende och död, underlättar hanteringen - kontrollen - av den egna döden och ger i slutänden också en mening med livet. Några av forskarna menar att dagens äldre människor saknar eller har begränsad erfarenhet och kunskap om döden, och därför kommer de äldre att ställas inför svårigheter en dag. Andra forskare menar däremot att äldre människor har erfarenheter, inre resurser och att de reflekterar över döden, vilket också har fått dem att ändra beteende och ändra fokus på livet.

I denna första del av kapitlet har jag alltså fokuserat på för studien relevant litteratur om äldre människors framtid, döende och död.

\section{Teoretiskt ramverk}

I den andra delen av kapitlet fokuserar jag perspektiv och begrepp med en mer specifik betydelse för studien. Livsloppsperspektivet, som har varit en av utgångspunkterna i studiens design och som ofta saknas i andra studier av detta slag, innebär att jag har studerat de intervjuades erfarenheter, föreställningar om och förhållningssätt till framtid, döende och död utifrån hela deras livslopp. Deras livslånga erfarenheter tillsammans med olika möten med döende och död genom livet i samspel med samhälleliga förändringar över tid, har utgjort en grund för hur jag skulle förstå deras funderingar kring det egna döendet, döden här och nu och inför framtiden 
(Jeppsson Grassman, 2005; Öberg, 2002). Begreppen erfarenhetsrum och förväntningshorisont (Koselleck, 2004), och kvantitativ respektive kvalitativ tid (Lundmark, 1989) har kommit in senare i processen. Det är begrepp som har låtit sig väl förenas med livsloppsperspektivet och som jag har använt som analysverktyg för att skapa förståelse för hur de intervjuade förhåller sig till tid - dåtid, nutid och framtid. Tredje åldern (Laslett, 1989; 1994) är också ett begrepp som knyter an till livsloppsperspektivet och som har varit en av utgångspunkterna i studiens design. Det har, närmare bestämt, inneburit att jag har problematiserat tredje åldern i förhållande till framtid, döende och död för att förstå huruvida de intervjuade, som kan kategoriseras som tredje åldrare, funderar på döden i vardagen eller inte. Ytterligare begrepp som naturligtvis har haft central betydelse för studien, och som definieras, är döende och död, liksom Walters (1994) idealtyper av olika synsätt på döende och död. De här idealtyperna har varit till hjälp i min förståelse av hur synen på döende och död historiskt har förändrats under mina intervjupersoners livstid och hur vissa förändringar även kan speglas i de intervjuades berättelser. Liksom litteraturen i min översikt har även perspektiven och begreppen kommit in under olika faser $\mathrm{i}$ arbetet med studien, några har varit utgångspunkter i studiens design, medan andra har tillkommit under analysprocessen. Det teoretiska ramverket har inte varit styrande. Det har snarare väglett mig under forskningsprocessen i enlighet med studiens abduktiva och hermeneutiska metodansats. Under arbetets gång "sker således en alternering mellan (tidigare) teorier och empiri, varvid båda successivt omtolkas i skenet av varandra" (Alvesson \& Sköldberg, 2008, s. 56).

\section{Livsloppsperspektivet}

Att använda livsloppsperspektivet $\mathrm{i}$ forskning om människans åldrande har blivit alltmer vanligt förekommande och utgör också ett betydelsefullt bidrag till den socialgerontologiska förståelsen av äldres åldrande. I denna studie har jag valt att ha livsloppsperspektivet som utgångspunkt i designen för att kunna diskutera de intervjuades berättelser kring den egna framtiden, döendet och döden med hela livsloppet som inramning. Perspektivet ska inte ses som en renodlad och färdigpaketerad teori som förklarar de intervjuades livslopp. Det ska i stället ses som en modell och ett analytiskt redskap, för att jag ska kunna tolka och förstå de intervjuades liv och deras syn på den egna framtiden, döendet och döden. Närmare bestämt, deras berättelser förstås bäst $\mathrm{i}$ ett sammanhang med hela livsloppets dynamik där åldrandet ses som en livslång process (Jeppsson Grassman \& Whitaker, 2013, s. 4). Sociologerna Clarke och Warrant, menar att tiden - då, nu och framtid - ofta låter sig sammanvävas i berättelser "When people talk about their lives, they reveal not only information 
about their past and present but also how they feel about the future" (Clarke \& Warrant, 2007, s. 483).

I slutet av 1900-talet ifrågasattes det traditionella livsloppsperspektivet för att det alltför starkt betonade kronologisering och institutionalisering av människans olika livsfaser. Det vill säga, livsloppsperspektivet hade mer karaktären av ett linjärt och normativt förlopp som betonade progression, där människan skulle passera fasta livsstadier - steg och faser - i rätt följd, alltså det enda genomförbara sättet att åldras och leva (jfr Holstein \& Gubrium, 2000). Det tycktes alltså inte finnas något utrymme för flexibilitet, med andra ord, att kunna pendla mellan stadierna, stanna kvar vid något av dem eller rent av vända tillbaka, börja om eller hoppa över. Dessutom tenderade perspektivet att vara deterministiskt och inte ta hänsyn till sociala, kulturella och historiska faktorer över tid. Synsättet ansågs förlegat och för fokuserat på åldersnormer och åldersbarriärer. I stället ville man se ett livslopp i förändring - ett flexiblare livsloppsmönster, åldersbarriärer som bröts och ett mer åldersintegrerat livslopp. Att åldrandet i stället skulle ses som en livslång och dynamisk process, där hela människas liv, från födelse till död, togs i beaktande. Alla åldersperioder skulle bli lika betydelsefulla att uppmärksamma. Dessutom ansågs det viktigt att samtidigt ställa människans biografi i relation till de sociala, kulturella och historiska kontexter som hon var en del av och hade vuxit upp i (Bengtson et al., 2002, s. 29ff; Jeppsson Grassman, 2005; Pilcher, 1995, s. 17ff; Öberg 2002, s. 44ff; jfr SOU, 2002:29).

Till livsloppsperspektivets fördelar hör alltså möjligheten att förena det individuella aktörskapet (mikronivå) med interaktionen med andra människor (mesonivå) och med de kulturella och sociala strukturerna (makronivå). Det sker genom samspelet mellan såväl individuella och sociala som historiska faktorer över tid och rum. Tidsbegreppet får här en central och mångdimensionell innebörd, där samspelet mellan individuella och samhälleliga förändringar fokuseras över tid. De olika livsfaserna under de intervjuades livslopp går inte att isolera och förstå var och en för sig, de måste förstås tillsammans - inte någon av faserna kan således exkluderas (Bengtson et al., 2002, s. 29ff; Giele \& Elder, 1998; Pilcher, 1995, s. 17ff; Öberg 2002, s. 44ff). Det finns också forskare som har invändningar mot livsloppsperspektivet och som anser att perspektivet har sina begränsningar:

trots att livsloppsperspektivet innehåller få explicita förutsägelser och förklaringar, betraktar somliga gerontologer det som deterministiskt och hävdar att det behöver integreras med mer tolkande perspektiv (Bengtson et al., 2002, s. 30 refererar till Marshall [1995]; jfr Holstein \& Gubrium, 2000). 
Ett centralt begrepp sett utifrån ett livsloppsperspektiv är alltså aktören. Sociologen Giddens betonar aktörskapet i sin struktureringsteori, det vill säga aktörens förmåga att reflektera över och reglera sina handlingar i samspelet med andra människor och med de närvarande sociala strukturerna som inramning. Han menar att det har blivit betydelsefullt för aktören att välja livsstil - rutiner, vanor, beteenden - att på egen hand utforma sina livsplaner i det senmoderna samhället (Giddens 1999; 2003).

I denna avhandling har jag under analysprocessen tagit hjälp av sociologerna Giele och Elders (1998) fyra nyckelfaktorer för att kunna tolka och förstå hur intervjupersonernas livslopp har gestaltat sig. Lokalisering - rör de intervjuades placering i tid och rum, det vill säga den historiska tid de lever i och var deras liv utspelar sig, som till exempel i det geografiska, socioekonomiska eller kulturella rummet. Social tillhörighet handlar om de intervjuades tillgång till och delaktighet i sociala relationer och sammanhang, vilket i min avhandling framförallt avser deras sociala relationer till familjemedlemmar, släktingar, vänner och föreningsaktiva. Individens egna resurser - avser de intervjuades resurser gällande intellektuell förmåga, hälsa, utseende, praktisk kompetens, etcetera. Tid och timing - handlar om de intervjuades tidsmässiga anpassning till situationer och händelser i det levda livet. Det rör både aktiv anpassning som att uppnå fastställda mål, liksom anpassning till sådant de ställs inför och inte kan påverka, som till exempel sjukdom, dödsfall, olyckor men även det egna åldrandet. Tid och timing inkluderar även de intervjuades subjektiva tidsuppfattning och känsla av samband mellan historisk tid, nutid och framtid:

Det inre psykologiska livsloppet skapas och omskapas i en ständig pågående process, med utgångspunkt från faktiska händelser i det förflutna och i nuet och utifrån tänkbara och planerade händelser i framtiden (Jeppsson Grassman, 2001, s. 310).

Tid och timing handlar också om social tid, det vill säga, olika roller som de intervjuade förväntas leva upp till utifrån påverkan av normer kring "när i livet olika saker 'normalt' förväntas hända" (Jeppsson Grassman, 2001, s. 310ff). Psykologen Neugarten, som introducerade begreppen "on time" och "off time", menar att människans olika roller genom livet är påverkade av en inre timing, vilken är konstruerad med sociala förtecken - så kallade biografiska scheman eller "färdplaner" - som människan bedömer sitt eget livslopp utifrån (Neugarten, 1979, s. 887ff; jfr Holstein \& Gubrium, 2000, s. 79; Jeppsson Grassman, 2001, s. 316f; Nurmi, 2005; Närvänen, 1994, s. 45f). 


\section{Aspekter av tid}

Ett par begrepp som jag har använt mig av $i$ analysprocessen och som låter sig väl förenas med livloppsperspektivet och med de intervjuades förhållningssätt till tid är erfarenhetsrum och förväntningshorisont. Det är begrepp som vanligtvis förekommer inom historieämnets teoribildning för att tematisera historisk tid, men som även går att använda inom andra forskningsområden för att skapa förståelse för hur människan förhåller sig till tid - dåtid, nutid och framtid. Enligt historikern Koselleck är begreppen erfarenhet och förväntan "sammanflätade med varandra så att den ena förutsätter den andra. Ingen erfarenhet utan förväntan, ingen förväntan utan erfarenhet" (Koselleck, 2004, s. 169). Begreppet erfarenhetsrum är ett tänkt rum hos de intervjuade där alla deras erfarenheter är samlade. Erfarenhet definieras som ett närvarande förflutet. Till sin karaktär är erfarenheten både personbunden och interpersonell. Ur minnet kan de intervjuade hämta erfarenhet från det egna livet såväl som från vetskapen om andras människors erfarenhet. De händelser som inträffar under deras liv och som leder fram till erfarenheter införlivas i minnet. I deras minne bevaras även tidigare generationers och institutioners erfarenheter, vilka har införlivats genom muntliga berättelser, skrivna texter, etcetera. Det handlar om samlade erfarenheter som hos de intervjuade både är rationellt bearbetade och omedvetet tillkomna. Händelsen som leder fram till erfarenheten är alltid densamma. Däremot kan erfarenheten förändras under tidens gång när nya erfarenheter görs eller då minnesbilden av en erfarenhet revideras. Begreppet förväntan är såväl personbundet som interpersonellt, och definieras som det icke än erfarna, en närvarande framtid som uppstår i nuet. Förväntningshorisonten är enligt Koselleck den "linje bortom vilken ett nytt erfarenhetsrum öppnar sig som ännu inte kan överblickas" (Koselleck, 2004, s. 173).

Begreppen erfarenhetsrum och förväntningshorisont är som sagt sammanflätade med varandra, men de är på intet sätt en spegelbild av varandra. Det går inte fullständigt att härleda en förväntan enbart med utgångspunkt i erfarenheter, utan i konstituerandet av en förväntan kan även ingå utifrån kommande inslag av exempelvis hopp, fruktan, önskan, vilja, oro, nyfikenhet, förnuft, etcetera. Följaktligen går det inte att hävda att intervjupersonernas erfarenheter till fullo kan determinera deras förväntningshorisont utan inkommande impulser utifrån. Det går dock att påstå att deras erfarenheter medverkar till förväntningshorisontens gestaltning - att det hos intervjupersonerna existerar en ständig växelverkan, spänning och ett "inre sammanhang mellan det förflutna och framtiden $i$ går, i dag och i morgon" (Koselleck, 2004, s. 170).

Historikern Lundmarks resonemang kring det inre sammanhanget mellan tidsskedena dåtid, nutid och framtid har varit till hjälp i analysar- 
betet. Lundmark framhåller den kvantitativa och den kvalitativa aspekten av tid i diskussionen kring människans sociala tidsuppfattning. Tiden i sig är varken kvantitativ eller kvalitativ, det intressanta är vad de intervjuade tillskriver tidsaspekterna för mening. Tidsaspekterna ska inte heller uppfattas som att den ena utesluter den andra, de är snarare beroende av och samspelar med varandra. Den kvantitativa aspekten av tid definieras utifrån uppfattningen att tiden utnyttjas som en resurs som kan fyllas med värdeskapande aktiviteter och praktiskt handlande. Den kvantitativa tidens värde och existens försvinner så att säga när tiden går. Till skillnad från den kvantitativa aspekten av tid där alltså resurserna förbrukas i nuet, så strävar de intervjuade efter att ge tiden ytterligare en mening, en varaktig sådan. Den kvalitativa aspekten av tid definieras utifrån de intervjuades förhållande till tidsskedena och hur tidsskedenas gemensamma samverkan skapar grundvalen för förståelsen av såväl samhället som kulturen (Lundmark, 1989, s. 15f, 72f, 186f). Lundmark konstaterar:

I kvantitativ mening är alltså förfluten tid för alltid borta och kommande tid ännu inte här. Men det betyder inte att det förflutna är oåtkomligt eller att framtiden inte kan påverka oss. Det förflutna finns kvar som lämningar och förväntningarna inför framtiden styr mycket i vår tillvaro. Genom minnen, lämningar och förväntningar kan vi låta andra skeden än det närvarande påverka oss och ge vår samtid dess kvalitet. Tiden får en innebörd som ligger utanför den snävt kvantitativa (Lundmark, 1989, s. 157).

\section{Tredje åldern}

Det är ofta problematiskt att kategorisera forskningspopulationen - exempelvis äldre människor, seniorer och pensionärer - därför att de inte utgör några homogena eller entydiga grupper, men det är trots allt nödvändigt att urskilja populationen på något vis (Gynnerstedt, 2011, s. 13). Ett par begrepp som jag har använt mig av i arbetsprocessen och som knyter an till livsloppsperspektivet är "ålder" och "tredje åldern", som också har varit en av utgångspunkterna i studiens design. Begreppen har varit viktiga, dels för mina kategoriseringar av forskningspopulationen, dels i analysarbetet av empirin och i synliggörandet av åldrandets mångfald.

När det gäller begreppet ålder kan det definieras och förstås på flera sätt. Kronologisk ålder definieras utifrån de intervjuades levnadsår; biologisk ålder handlar om en uppskattning av de intervjuades förväntade livslängd; social ålder utgår ifrån de vanor, sociala roller och positioner de intervjuade har i samhället; kognitiv ålder definieras utifrån den ålder de intervjuade upplever sig ha; subjektiv ålder handlar om de intervjuades upplevda ålder i relation till andra åldersgrupper (Gynnerstedt, 2011, s. 13). Ett annat sätt att kategorisera och definiera äldre människor är att använda begreppet 
"tredje åldern". Tudelningen av ålderdomen mellan den tredje och fjärde åldern, som har präglat den socialgerontologiska disciplinen under ett par decennier, utvecklades av historikern Laslett under 1980-talet. En anledning till att dessa begrepp introducerandes i forskningen om äldre och åldrande var att komma bort från kronologiseringen av livsloppet. Enligt Laslett omfattar tredje åldern individer som är oberoende, friska och aktiva pensionärer där själförverkligandet anses som eftersträvansvärt, medan fjärde åldern omfattar individer som är beroende, sjuka, skröpliga och döende pensionärer (Laslett, 1989; 1994). I mångt och mycket har denna uppdelning, med sina många fördelar och användbarhet, trots allt fått utstå en del kritik. Dels handlar det om när en människa anses passera gränsen mellan tredje respektive fjärde åldern, vilket oftast inte sker plötsligt. Snarare är det en pågående process, ett kontinuum, vilket begreppen på sätt och vis missar i sin definiering. Dels anses uppdelningen problematisk och leder, liksom kategoriseringar överhuvudtaget, till förenklingar. Den ena kategorin förfördelas och den andra framhålls och när den ena lyfts fram riskerar den andra att inte bli uppmärksammad. Denna polarisering såväl skapar som upprätthåller vad som anses vara ett normalt eller ett onormalt åldrande. Alltså, som två parallella spår löper de genom de senaste årens socialgerontologiska forskning, där det ena spåret utgör eländesbilden av äldre och det andra spåret utgör livsnjutandebilden av äldre. Det ena spåret betonar det positiva medan det problematiska skyms, och det andra spåret framhåller det negativa medan de positiva aspekterna undanhålls (Andersson, 2008, s. 42f; 2009, s. 210ff; Gynnerstedt, 2011, s. 14; Thelin, 2011, s. 33ff). Kontentan av kritiken är att indelningen

av äldre personer i en tredje och en fjärde ålder, som ursprungligen syftade till att visa på divergens inom kollektivet äldre personer, skapar därmed snarare nya homogeniserade stereotyper än synliggör mångfald inom kollektivet äldre personer i sin helhet (Thelin, 2011, s. 43; se även Andersson \& Öberg 2004).

Uppdelningen mellan tredje och fjärde åldern har så att säga fått spegla "det önskvärda och det dåliga åldrandet" (Thorslund, 2012, s. 137). Redan tidigare började forskare dock uppmärksamma att uppdelningen av äldre i en tredje och i en fjärde ålder homogeniserade snarare än synliggjorde åldrandets mångfald. Det forskarna åsyftar är bilden av en forskning om tredje åldern nästan helt utan inslag av existentiella och andliga dimensioner av liv, döende och död, vilket i stället kopplas samman med begreppet fjärde åldern. Johnson menar att - "The life span researchers' preoccupation with succesful aging, wellbeing, and life satisfaction will need to take much more account of the spiritual dimension" (Johnson, 2009, s. 667). Även psykologen Wong ställde sig frågande till - efter att ha be- 
sökt en gerontologisk konferens där fokus hade varit på successful aging varför det enbart talades om fysisk hälsa och fysiska aktiviter och inte om existentiella och andliga dimensioner - "This incident caused me to rethink the meaning of successful aging: Have the experts on successful aging missed something important to aging population" (Wong, 2000, s. 23; 1998). Wongs avsikt är att göra forskare uppmärksamma på betydelsen av att synliggöra döden i forskningen om successful aging. Han menar att livet och döden är oupplösligt förbundna med varandra, som i ett slags memento mori som ger livet dess mening.

\section{Definition av döende och död}

Ytterligare begrepp som har haft central betydelse för studien är döende och död. Flera forskare menar dock att det är viktigt att separera begreppen döende och död och beakta den skillnad som föreligger mellan begreppen. Ofta används nämnda begrepp synonymt och utan definition:

Det är lätt att sätta likhetstecken mellan döden och döendet och därmed betrakta det som samma sak. I dagligt tal uttrycker vi oss gärna så. Det är emellertid viktigt att hålla isär dessa båda begreppen både i tanke, handling och i forskning. Synen på döden och synen på döendet är inte nödvändigtvis densamma (Rahm Hallberg, 2010, s. 90).

Även jag anser det som problematiskt i genomläsningen av relevant litteratur att forskare sällan använder de två begreppen konsekvent. En vanlig uppdelning av begreppet döden är - döendeprocessen, händelsen död själva dödsögonblicket, och tillståndet död (Österlind, 2009, s. 53). Det är framförallt döendet som är komplicerat att definiera, det vill säga - När anses någon vara döende, när börjar döendeprocessen? Inte minst äldre människors döende är svårdefinierbart. Kellehear menar att äldre döende människor sällan vet om att de befinner sig i en terminal vårdsituation. De behandlas inte som döende varken av närstående eller personal - de befinner sig med andra ord varken i livet eller i döendet. Anledningen är att det är svårt att identifiera början på äldres döende - medicinskt, moraliskt och socialt. Detta, hävdar Kellehear, omöjliggör för äldre döende människor att inta en döenderoll och döendeidentitet. Döendet kan varken bli god eller väl hanterad om det inte existerar ett igenkännande av döendet. Ofta är äldre skröpliga och placerade på vårdhem där "health care" prioriteras framför "dying care", vilket leder till att det blir svårare att förbereda sitt döende och sin död (Kellehear, 2007a, s. 210ff; se även Feigenberg, 1977; Qvarnström, 1978). I min studie utgår jag från uppdelningen döendeprocessen, händelsen död - själva dödsögonblicket, och tillståndet död. Studiens intervjupersoner fick frågor om begreppen döende och död, om 
de ansåg att det förelåg någon skillnad mellan dem. Svaren var dock inte helt klargörande. Flertalet svarade att det förelåg en skillnad, vilket några inte ansåg. I intervjuerna däremot flöt begreppen ofta ihop. Något som dessutom var svårt att urskilja i litteraturgenomgången var huruvida forskarna avsåg de intervjuades syn på det egna döendet och döden eller om de avsåg de intervjuades syn på andra människors döende och död eller döden som fenomen. Dessa tvetydigheter var då och då påtagliga också $\mathrm{i}$ min studie, men i de flesta fall gick det oftast att förstå av sammanhanget om de intervjuade avsåg den egna döden, andras död eller döden som fenomen.

\section{Olika synsätt på döende och död}

Walters (1994) idealtyper av olika synsätt på döende och död har utgjort en av utgångspunkterna i det teoretiska ramverket. De här idealtyperna har varit till hjälp i min förståelse av hur synen på döende och död historiskt har förändrats under den tid mina intervjupersoner har levt, hur de intervjuades berättelser speglar dessa förändringar, men även hur deras berättelser avviker från dessa idealtyper.

Min studie handlar om de intervjuades minnen och erfarenheter av döende och död genom livet. Det är erfarenheter gjorda under tidsperioden från 1920-talet och fram till och med 2010-talet. Det handlar om en historisk period med genomgripande demografiska, tekniska, medicinska såväl som socio-ekonomiska, politiska och kulturella förändringar av det svenska samhället (Giddens, 1999; Liedman, 1997), och inte minst om en förändrad syn på och förhållningssätt till döende och död (Ariés, 1978; Kellehear 2007a; Magnusson, 2000; Walter, 1994). Det var under en tid då människors livsvärldar omvandlades i takt med att Sverige lämnade det traditionella och dominerande jordbrukssamhället för att bli ett modernt industrisamhälle, och småningom övergå till att bli ett senmodernt samhälle. En parallell genomgripande omvandling har även synen på döende och död genomgått. Bland andra Magnusson (2000) och Walter (1994) ger en beskrivning av förhållningssätten till döende och död utifrån tre historiska idealtyper - det traditionella, det moderna och det postmoderna - för att förstå hur människans hantering av döden har förändrats över tid (se även Ariés, 1978; Bauman, 1994). Dessa synsätt på döende och död är socialt konstruerade, de finns inte renodlade var för sig. Det existerar således inga vattentäta skott mellan idealtyperna, de är överlappande. De har emellertid ett visst ursprung $i$ en särskild kulturell och socialhistorisk kontext, men samtliga är i högsta grad närvarande i det svenska samhället av i dag (Magnusson, 2000, s. 17; Walter, 1994, s. 47). Ett av syftena, enligt Walter, med den här klassifikationen är att visa hur synen på och hanterandet av döden historiskt har förändrats och samtidigt kunna förklara 
och förstå hur komplex den västerländska döende- och dödskontexten är i dag - och även synliggöra hur motsägelsefullt dessa idealtyper kan vara hos en och samma individ, eller hur de olika generationerna inom en och samma familj kan ha införlivat olika synsätt (Walter, 1994, s. 60f).

Det som karaktäriserade det traditionella synsättet var att religionen och invanda sociala och kulturella seder och bruk till största delen låg bakom hur döende och död hanterades och kontrollerades såväl praktiskt som mentalt och själsligt. Det var framförallt familjen, släktingar, vänner och kyrkan - alltså det kollektiva - som tillsammans bemästrade och genomförde det praktiskta och det rituella arbetet vid någons döende och död. Döende personer dog ofta i hemmet och döden var närvarande i vardagslivet. Döden var en del av livet, men det var livet efter döden som var det väsentliga, det vill säga, själens resa till himmelriket. Historiskt har det traditionella synsättet sitt ursprung i tiden före industrialiseringen - från medeltiden och framåt, då bondesamhället var förhärskande.

Det moderna synsättet på döende och död sammanföll med tiden för industrialiseringen då tilltron till både framtid och vetenskap började prägla det svenska samhället. Samtidigt bredde sekulariseringen ut sig med en rationell och individualistisk syn på livet. Det moderna synsättet på döden kännetecknades av den medicinska vetenskapen med dess experter - döden reducerades till att bli blott en medicinsk affär. Sjukvårdens huvudsakliga mål var att bota och rädda liv, varför den döende ansågs vara en anomali, en sjukdom och döden ett misslyckande. Det sades också att - "Den reduktionistiska medicinen bidrar som samhällets viktigaste redskap till att öka främlingskapet inför döden" (Alvsvåg, 1985, s. 26). Sjukvården och begravningsentreprenörerna tog över allt mer av det praktiska arbetet med den döende och döda människan - döden blev mer institutionaliserad, kommersiell och offentligt kontrollerad, vilket i förlängningen innebar att döden blev gömd, glömd och anonymiserad och enbart en privat affär för familjen.

Det postmoderna synsättet på döende och död sammanföll med den alltmer påtagliga globaliseringen. Ett kunskaps- och informationssamhälle började växa fram - alltså samhället av i dag. Det postmoderna synsättet på döden kännetecknas av att det subjektiva och privata sätts i fokus, det vill säga, den döendes erfarenheter, personliga val, livsstil och känslor är av central vikt, och den döende ska själv ha möjlighet att vara med och välja behandlingssätt och så vidare. Det är inte längre ovanligt att följa någons döendeprocess och det är inte längre konstigt att ha sett en död människa. Döendet och döden anses nu som en viktig fas som tillhör ett biologiskt och ett psykosocialt skeende av livet (Socialstyrelsen 2007). Det postmoderna synsättet utgör, enligt Walter, dödens renässans där individen centreras utifrån ett holistiskt perspektiv som inkluderar kropp, 
medvetande och själ. I slutänden är det individen som har "auktoritet" och "äganderätten" till sin egen död men i nära relation både till religionen, som i det traditionella synsättet, och till den medicinska vetenskapen, som i det moderna synsättet (Magnusson, 2000; Walter, 1994; se även Alvsvåg, 1985).

Historikern Åhrén Snickare menar att det finns flera skäl till att problematisera dessa idealtyper. Först och främst ser hon, och är även kritisk till, att forskare drivs "av en föreställning om att dagens sätt att umgås med döden är dåligt, att det bör förändras och att vi kan lära av det förflutna", alltså "en romantisk föreställning om att döden var 'naturligare' 'förr', det vill säga, innan moderniseringen upplöste de gamla fina sederna" (Åhrén Snickare, 2002, s. 17ff; se även Åkesson, 1997). Det tycks alltså finnas en tendens bland forskare att rangordna idealtyperna och att också lägga in sina egna värderingar när slutsatser dras. Dessutom ifrågasätter hon om det överhuvudtaget går tala om en gömd, glömd och anonymiserad död under den moderna tidseran (för vidare diskussion kring "death taboo", se Ariés, 1978; Gorer, 1965; Kellehear, 2007a). Etnologen Åkesson menar, i linje med Åhrén Snickare, att påståendet om den gömda och glömda döden är överdriven:

I stället för den gamla tidens alla dödsritualer verkar vi nu stå inför ett tomrum, ett dödens svarta hål. Men om det gamla och välbekanta har försvunnit, har vi verkligen inte fått något annat i stället? Min utgångspunkt är att förändring inte bara innebär upplösning utan också nyskapande (Åkesson, 1997, s. 12).

Åkesson menar också att i en samtid av allt mindre tvingande kollektiva traditioner och när döden inte längre är reserverad för experter, så möjliggör detta i större utsträckning individuella val inför döden, men också ansvar. Vår samtid står, påpekar Åkesson, inför en spännande hybrid av religiös såväl som profan ritualisering av döden där individen eftersträvar det autentiska och äkta - en "intimisering av döden" (Åkesson, 1997, s. 17f, 182f). Vidare, anser hon, att människan

finner sig helt enkelt inte i att förnekas utrymme för personliga synpunkter, önskemål eller val. Lyhördhet inför de anhöriga är /.../ kännetecknet för dödens professionalisering i dag. /.../ I dödsannonser, på gravstenar, i val av blommor och färg på kistan understryks allt mer den dödes individualitet. Så som i livet, så bör den avlidne vara också i döden (Åkesson, 1997, s. 180f).

Det postmoderna samhället tycks erbjuda en mångfald av alternativ för människan när hon ställs inför döden. Det individuella synsätt som präg- 
lar dagens samhälle innebär inga hinder utan enbart möjligheter. Individuella idéer och praktiker kring döende och död som befruktar varandra ses som tillgångar och mångfald, inte som att det postmoderna samhället skulle ha drabbats av fragmentering och ytlighet. Definitionen av detta mera individuella synsätt är inte heller synonymt med att döendet och döden ska ske i den privata sfären. Det individuella synsättet möjliggör ständigt nya synteser som människor anammar. Inte sällan kan dessa synteser mynna ut i kollektiva och i offentliga praktiker, som till exempel självhjälpsgrupper, internetanslutna mötesplatser för döende och sörjande och allmänt hållna minnesstunder (Howarth, 2000; 2007). I det postmoderna samhället ses också en antydan till fragmentering och ytlighet, det vill säga, har människan verkligen möjlighet att välja mellan allt som det postmoderna erbjuder utan hjälp av experter? Det finns ingen möjlighet menar bland andra Walter - man dör bara en gång och därför behövs någon som kan ge råd och ledning och komma med alternativa förslag (Walter, 1994).

Sammanfattningsvis - min översikt av kunskapsläget har inte enbart haft betydelse för studiens forskningsbakgrund, jag har även använt mig av denna litteratur i analysen för att jämföra och kontrastera mina resultat mot tidigare forskning. De perspektiv och begrepp som har varit av central betydelse har kommit in under olika faser i arbetet med studien, några har varit utgångspunkter i studiens design, medan andra har tillkommit under analysprocessen. Det teoretiska ramverket har inte varit styrande men däremot min vägledning under forskningsprocessen, enligt den abduktiva och hermeneutiska metodansats som denna studie utgår från.

Efter denna genomgång av tidigare forskning om äldres framtid, döende och död och val av studiens teoretiska ramverk - presenterar jag i nästa kapitel 3 studiens metoder, material och genomförande. 



\section{KAPITEL 3}

\section{Metoder, material och genomförande}

I det föregående kapitlet redogjorde jag för studiens teoretiska ramverk och diskuterade även tidigare relevant forskning. I detta kapitel presenterar jag studiens metoder, material och genomförande. Val av metod/er till en studie sker aldrig i ett vakuum, det sker i en process som i hög grad ger form åt studiens syfte, dess forskningsfrågor, teoretiska ramverk och kunskapsanspråk (Alvesson \& Sköldberg, 2008, s. 18; Aspers, 2007, s.12ff). Sålunda, utifrån syftet - att utforska äldre människors föreställningar om och förhållningssätt till den egna framtiden, döendet och döden - bedömde jag den kvalitativa forskningsmetoden med den kvalitativa intervjun som mest lämplig för studiens genomförande (Kvale \& Brinkmann, 2009). Den kvalitativa intervjun kännetecknas av:

... face-to-face encounters between the researcher and informants toward understanding informant's perspectives on their lives, experiences, or situations as expressed in their own words (Taylor \& Bogdan, 1984, s. 77).

I det följande avsnittet fokuserar jag den kvalitativa forskningsmetoden, därefter diskuterar jag studiens material och genomförande - urvalsprocess och överväganden, datainsamling, analys- och tolkningsprocess, etiska överväganden och studiens trovärdighet. Kapitlet avslutas med en kortfattad presentation av de intervjupersoner som ingår i studien.

\section{Den kvalitativa forskningsmetoden}

Denna studie har tagit sin utgångspunkt i den kvalitativa forskningsmetoden där den kvalitativa intervjun utgör ett av flera tillvägagångssätt för att uppnå kunskap om människan och för att förstå henne. Den kvalitativa forskningsmetoden är omstridd och får ibland kritik (Alvesson \& Sköldberg, 2008, s. 18; Aspers, 2007, s. 11), metoden anses emellertid vara öppen för variationer och mångfald i produktionen av kunskap (Widerberg, 2002, s. 30). Valet av metod utgick från min formulering av syftet, från mina forskningsfrågor och min ambition att uppnå kunskap om och att finna sociala mönster och fenomen kring äldres framtid, döende och död och att förstå dessa mönster sedda utifrån ett livsloppsperspektiv. För att kunna analysera, tolka och förstå äldres föreställningar om och förhållningssätt till den egna framtiden, döendet och döden, intervjuades 27 per- 
soner. Frågorna berörde deras livserfarenheter, värderingar och förväntningar inför framtiden och de förhållanden som präglade deras nuvarande liv. En metod som sålunda möjliggör att "qualitative researcher obtains first-hand knowledge of social life unfiltered through concepts, operational definitions, and rating scales" (Taylor \& Bogdan, 1984, s. 7).

Ett par grundläggande aspekter brukar förknippas med den kvalitativa forskningsmetoden, vilka forskaren bör problematisera och förhålla sig till. Det är aspekter som bland annat handlar om människan, om världen och dess beskaffenhet och om kunskapsanspråk (ontologiska och epistemologiska överväganden) (Alvesson \& Sköldberg, 2008, s. 17; Aspers, 2007, s.11ff; Bryman, 2009, s. 34ff, 249ff). För att läsaren ska ges möjlighet att bedöma värdet av forskningen såväl som dess kunskapsanspråk bör forskaren beskriva och motivera hur hon har genomfört studien utifrån alla dessa aspekter (Thomsson, 2010, s. 34, 41; Widerberg, 2002, s. 18). Utgångspunkten i studien har varit att allt har sin grund i det mänskliga medvetandet och handlandet, och att "verkligheten" eller aspekter av "verkligheten" är socialt konstruerade (Bryman, 2009, s. 30f). Intervjupersonerna ses som agerande sociala aktörer som, via mellanmänsklig interaktion med andra är med och upprätthåller, skapar och rekonstruerar den sociala och den kulturella föränderliga "verklighet och värld" som de lever i och samtidigt formas av, i både tid och rum. De intervjuades syn på exempelvis döende och död är socialt konstruerad då den skapas och omskapas i interaktion med andra människors egna och gemensamma erfarenheter, kulturella normer och värderingar. Den "verklighet" som intervjupersonerna konstruerar är den "verklighet" som jag som forskare undersöker och måste ta hänsyn till. Dessutom måste jag beakta att jag som forskare även anses vara medkonstruktör av denna "verklighet" (Aspers, 2007, s. 28; Kvale \& Brinkmann, 2009, s. 15ff). Det innebär att under intervjusamtalen konstrueras och rekonstrueras olika aspekter av "verkligheten" då intervjupersonernas erfarenheter och förväntningar inför framtid, döende och död vävs samman med forskarens förförståelse, frågor, tolkningar och förståelse. En annan viktig aspekt är också att den "verklighet" som konstrueras i intervjusituationen är att den skapas med anledning av att jag som forskare uppmanar intervjupersonerna till att börja fundera kring framtid, döende och död. Det är för övrigt inte säkert - i det här fallet - att sådana funderingar annars utgör en del av deras vardagliga tankegångar.

Studiens utgångspunkt är att den kvalitativa intervjun är en kunskapsproducerande aktivitet. Det är alltså under intervjun i samspelet mellan intervjupersonerna och mig som forskare som kunskap produceras. Det sker med hjälp av de erfarenheter, tankar och föreställningar kring olika teman som ömsesidigt förmedlas mellan oss (Kvale \& Brinkmann, 
2009 , s. 18). Den kunskap som konstrueras är kontextuellt baserad, flertydig, den är varken självklar eller "sann" kunskap, "sanningen" är mångtydig. Att det finns fler sanningar måste beaktas av mig som medkonstruktör till den kunskap som produceras. Det innebär att flera "sanningar" existerar parallellt, samtidigt som det betyder att även om jag har ett tolkningsföreträde just nu så innebär inte det att de resultat som förmedlas i studien skulle vara de slutgiltiga bara för att jag är en del av denna process. Thomsson säger:

Det går aldrig att hävda att resultaten som man vill ha god kvalitet på är objektiva, sanna och en gång för alla fastslagna. De är snarare flyktiga och bara till för att ge ett bättre underlag för alla som vill förstå just det fenomen som studeras (Thomsson, 2002, s. 30).

Den kvalitativa forskningsmetodens användare har då och då kritiserats för sina alltför subjektivt genomförda undersökningar med resultat som anses sprungna ur vad forskaren själv uppfattar som väsentligt och viktigt. Den kvalitativt inriktade forskaren anses inte vara värderingsfri och objektiv i sin forskning, den antas spegla forskarens personliga åsikter eller känslor. Kritiker menar att när forskaren ställer frågor utifrån sina egna intressen blir forskaren medkonstruktör till den kunskap som produceras. Det får konsekvenser när andra forskare vill replikera en kvalitativ forskning. På något sätt är "det forskaren själv som är det viktigaste redskapet vid datainsamlingen" (Bryman, 2009, s. 270) och svårigheter uppstår vid replikering en kvalitativ studie. Även de intervjuade kan påverkas av forskarens egenskaper som kön, ålder och personlighet. I förlängningen skulle det kunna påverka analys, tolkning och resultat. Det är viktigt att forskaren begrundar dessa förhållanden genom reflektion, medvetenhet och en personlig förförståelse för hur en sådan inverkan kan uppstå (se nedan).

Kritiken mot den kvalitativa metoden gäller även att resultaten inte går att generalisera. Thomsson ställer sig frågande till "om det överhuvudtaget är möjligt att generalisera resultat om man inte ansluter sig till det positivistiska sanningssökandet" (Thomsson, 2002, s. 33). Syftet med min studie av de intervjuades förhållningssätt till den egna framtiden, döendet och döden har varit att uppnå en god förståelse av det studerade fenomenet och på så vis uppnå en viss generaliserbarhet i relation till forskningsområdet. Detta har gjorts genom resonemang och argumentation med relevant empiri som stöd. Mina intervjupersoners föreställningar och förhållningssätt kan sålunda inte anses vara representativa för samtliga äldre människor i Sverige, men däremot kan de mönster och fenomen som framkommer i analysen hjälpa till att förstå äldre människors förhållningssätt till framtid, döende och död. Eller som Bryman väljer att förklara 
begreppet generalisering i en kvalitativ forskningsmetods kontext:

Resultaten från den kvalitativa forskningen ska i stället generaliseras till teori och inte till populationer. Det är "den bindande kraften i det teoretiska tänkandet" [Mitchell, 1983, s. 207] och inte statistiska kriterier som är det avgörande när generaliserbarheten i resultaten från en kvalitativ undersökning diskuteras. Det är med andra ord kvaliteten på de teoretiska slutsatser som formuleras på grundval av kvalitativa data som är det viktiga vid bedömningen av generaliserbarheten (Bryman, 2009, s. 270f).

\section{Urvalsprocess och överväganden}

\section{Urvalskriterier}

Utifrån det formulerade syftet med studien och genomgången av relevant tidigare litteratur framkom fyra mer grundläggande urvalskriterier för denna studie. För det första skulle de intervjuade vara vid relativt god hälsa, eftersom tidigare forskning i större utsträckning har beskrivit livssituationen för äldre som är skröpliga eller döende. Flertalet av de personer jag kom att intervjua kände sig relativt friska. Några var mindre fysiskt rörliga men just för stunden lade de inte någon större tonvikt vid det. Ett par hade tidigare under livet drabbats av cancer, en sjukdom som de menade hade satt djupa spår i både kropp och själ. För det andra skulle de intervjuade bo i ordinärt boende, eftersom tidigare forskning ofta fokuserat äldres döende och död på vårdhem, sjukhem och i särskilt boende. Anledningen till detta kriterium var att jag även ville ställa frågor om hemmets betydelse, deras inställning till andra boendeformer och hur de skulle ställa sig till en eventuell framtida flytt, exempelvis till ett särskilt boende.

För det tredje skulle intervjupersonerna vara 70 år eller äldre. De 27 personer som jag kom att intervjua var mellan 70-91 år vid intervjutillfället år 2010. Den äldsta var född år 1919 och de yngsta var födda år 1940. Att den nedre gränsen sattes vid 70 år berodde framförallt på att jag ville att de skulle ha en viss tidsmässig distans till det tidigare yrkesverksamma livet. Det skulle alltså finnas en möjlighet för dem att berätta och reflektera kring livet efter pensioneringen och vad som hade hänt sedan dess med exempelvis hälsa, kropp och sociala relationer. Att en övre åldersgräns aldrig fastställdes innebar att jag fick tillgång till ett mer omfattande åldersspektrum, vilket gjorde det möjligt att uppnå en bred förståelse kring äldre människors tankar om den senare delen av livet. Jag har även tagit deras kronologiska åldrar i beaktande, det vill säga, att det kan vara skillnad mellan att vara uppvuxen på 1920-, 1930- eller 1940-talet. Normer och traditioner kring döden kan ha varierat och haft olika innebörder. 
Detsamma gäller deras syn på den kvarvarande tiden, det vill säga framtidsorienteringen kan variera för 70-åring och en person som nyss fyllt 91år.

För det fjärde var målsättningen att eftersträva en jämn könsfördelning och en stor variation på civilstånd och familjeförhållanden. Av de utvalda intervjupersonerna var 15 kvinnor och 12 män. Variationen i de intervjuades civilstånd och familjeförhållande var stor, såväl gifta, änkor, änklingar som ensamstående, skilda och sambos, med eller utan barn och barnbarn. 3 ensamstående intervjupersoner hade inte barn, 2 intervjupersoner hade barn men inte barnbarn och övriga hade sålunda barn och barnbarn, och några även barnbarns barn. Jag ville få den här variationen för att se om civilstånd och familjeförhållande var faktorer som påverkade deras erfarenheter av, föreställningar om och förhållningssätt till framtid, döende och död.

Av de 27 intervjupersonerna var 10 bosatta på landsbygden. Intervjupersonerna var geografiskt utspridda från Skåne till Östergötland. De bodde i byar eller mindre orter där invånarantalet pendlade mellan drygt 800 till ungefär 17000 personer. De övriga 17 bodde och levde i större städer i norra Götaland och i Svealand med ett ungefärligt invånarantal på mellan 80000 och 800000 personer.

Det är inte ovanligt vid arbete med kvalitativ forskning att man i ett inledningsskede vill förvissa sig om exakt hur många personer som behöver intervjuas för att kunna färdigställa studien (Taylor \& Bogdan, 1998, s. 93). Något bra svar finns dock inte. Kvale och Brinkmann poängterar "Intervjua så många personer som behövs för att ta reda på vad du behöver veta". Syftet med en studie är emellertid ofta avgörande för hur många personer som är nödvändigt att intervjua. Det är inte ovanligt att 15 +/- 10 personer intervjuas i kvalitativa studier (Kvale \& Brinkmann, 2009, s. 129). Inledningsvis bestämde jag ett ungefärligt antal tilltänkta intervjuer till 20-25. Jag ansåg att det var ett antal som skulle ge en bred förståelse och ett bra underlag för de analyser och tolkningar jag ville genomföra - för att finna en större mängd nyanser och paradoxer i materialet och för att på ett mer övertygande sätt kunna argumentera för den uppnådda kunskapens trovärdighet och giltighet. Efter att ha samtalat med 27 intervjupersoner fann jag underlaget vara tillräckligt för att kunna genomföra analyser och tolkningar.

\section{Hur och var fann jag intervjupersonerna?}

Jag har använt mig av olika sökvägar för att nå ut till potentiella intervjupersoner. Det var ett sätt att få större spridning, geografiskt, socialt och kulturellt, men också för att nå ut till dem som annars kanske hade varit svåra att nå. I samband med att kontakt togs med äldre människor över- 
räcktes också ett informationsbrev (se bilaga 1) som gav en kort beskrivning av syftet med studien. Först vände jag mig till några församlingar $\mathrm{i}$ Svenska kyrkan. I tre av de utvalda församlingarna fick jag kontakt med sammanlagt 7 intervjupersoner. Jag antog att jag, genom att välja intervjupersoner som var engagerade i Svenska kyrkan skulle kunna få möjlighet att samtala med personer som funderat på andliga frågor och som hade en viss öppenhet kring frågor om döden.

Via Pensionärernas riksorganisation (PRO) fick jag kontakt med 6 intervjupersoner. Att jag valde PRO som sökväg berodde på att det är en intresseorganisation vars uppgift bland annat är att öka äldre människors inflytande i samhället. Jag antog att som PRO-medlemmar skulle intervjupersonerna ha ett engagemang för frågor kring vård och omsorg, och att det skulle kunna ha betydelse för hur de själva såg på den egna framtiden, döendet och döden. Det märktes med all tydlighet att några var vana retoriker, som inte sällan hade politiska budskap att förmedla i sina funderingar kring framtiden. En av de intervjuade blev intresserad av mitt urvalsförfarande och erbjöd sig att "få fram" ett antal potentiella intervjupersoner. Tillvägagångssättet kallas "snöbollsmetoden". Forskaren tar hjälp av sina intervjupersoner för att identifiera personer som kan tänkas delta i en undersökning. En fördel med detta urvalsförfarande är att man kan nå dem som aldrig annars hade ställt upp. Till nackdelarna hör att selektionen kan fastna i ett slags "nätverk" där presumtiva intervjupersoner kommer från liknande sociala och kulturella förhållanden (Aspers, 2007, s. 91; Taylor \& Bogdan, 1998, s. 93). Genom detta tillvägagångssätt fick jag kontakt med ytterligare 3 intervjupersoner.

Efter att ha vänt mig till två av civilsamhällets stora aktörer, Svenska kyrkan och PRO, för att få kontakt med intervjupersoner, var mitt mål att sedan hitta intervjupersoner som inte tillhörde eller var mindre aktiva i föreningslivet. Genom ett par av mina kollegor fick jag kontakt med sammanlagt 6 intervjupersoner. Därefter vände jag mig till en släkting som tipsade om ytterligare 5 - syftet var att hon skulle hitta några personer som var ensamstående. Kontaktpersonen hade själv inte någon relation till de här personerna mer än att hon kände dem till namnet.

26 intervjuer kom att genomföras, varav en parintervju. Således bestod det empiriska materialet av 27 intervjupersoners berättelser kring framtid, döende och död. Det visade sig att påfallande många av de intervjuade, trots varierande livssituation, var mycket föreningsaktiva. Bara 3 intervjupersoner hade inte ett sådant engagemang. Samtliga intervjuade skulle alltså kunna kategoriseras som "typiska tredje åldrare" sett till den rådande definitionen på tredje åldrare - oberoende, aktiva, resursrika och handlingskraftiga (Gynnerstedt, 2011, s.190). Det som är viktigt att beakta är - att ett aktivt föreningsliv skulle kunna ha betydelse för hur intervju- 
personerna såg på den egna framtiden, döendet och döden i förhållande till en person utan ett sådant engagemang. Det var få som inte var aktiva i någon organisation, varför det är viktigt att vara uppmärksam på att denna begränsning eventuellt kan ha betydelse för resultaten.

\section{Datainsamling}

\section{Intervjuguide}

Den intervjuguide jag kom att använda i studien baserades på den semistrukturerade intervjun (se bilaga 2). Anledningen var att det skulle finnas utrymme för specifika teman parallellt med öppna intervjufrågor. Dessutom gavs intervjupersonerna mer utrymme och större frihet att fördjupa sig i enskilda frågor, de hade även möjlighet att avvika från frågorna om de var inne på något relevant sidospår. De hade också chansen att berätta mer om det som de ansåg vara relevant och viktigt. Intresset riktades således mot intervjupersonernas ståndpunkter, erfarenheter och förväntningar (Bryman, 2009, s. 300ff).

Ett antal bestämda teman med tillhörande frågor fastställdes, vilka intervjupersonerna fick förhålla sig till, fördjupa och vidareutveckla under intervjusituationen. Valda teman var - en tillbakablick på livet som har varitvardagslivet - framtiden - egna erfarenheter av döende och död, ett tillbakablickande perspektiv - tankar och föreställningar om det egna döendet och dödenvad händer efter döden - tankar kring döende och död $i$ vardagslivet. Avslutningsvis ställde jag ett par frågor kring intervjusituationen och om de själva hade några frågor. Dessa teman med tillhörande frågor hade sin grund i studiens syfte och forskningsfrågor, och de var även utformade så att de skulle inbegripa intervjupersonens biografi. Genom att ställa frågor om historisk tid såväl som nutid och framtid så skulle det möjliggöra en förståelse av hela intervjupersonens livslopp. De olika temana kom i ordningsföljd i intervjuguiden, men det var inte ovanligt att de hade en annan ordning under intervjusamtalet. Det var inte heller ovanligt att intervjupersonerna ägnande mer tid åt vissa teman och berättade mer detaljerat kring dem. Detsamma gällde frågornas ordningsföljd inom respektive tema, som under intervjun inte sällan ställdes en annan ordning. Ofta blev det så att intervjupersonerna berättade utan att frågorna ens behövde ställas. Intervjuguiden fungerade mer som en minneslista över teman och frågor som skulle behandlas (Bryman, 2009, s. 304; Thomsson, 2010, s. 59). Intervjupersonerna fick därför stort utrymme att berätta om sina erfarenheter, tankar och föreställningar kring framtid, döende och död utan att samtalet slaviskt följde intervjuguidens struktur. 


\section{Reflektioner kring intervjuförfarande och transkribering}

Av de 26 intervjuerna genomfördes 23 i intervjupersonernas hem, 2 intervjuer i föreningslokaler, samt 1 intervju på ett café. Det var intervjupersonernas önskemål som fick styra var intervjuerna skulle hållas. Att intervjuerna genomfördes i hemmet innebar också att det gavs möjlighet för de intervjuade att plocka fram fotografier, album, visa upp föremål som någon anhörig skulle få ärva, etcetera. Det skedde på eget initiativ och blev ibland till en del av deras berättelser (jfr Wenger, 2002). Inte sällan visade de mig runt i sina hem och för många tycktes det vara betydelsefullt att få berätta hur viktigt hemmet var för dem. Dessutom bjöd de intervjuade ofta på kaffe, några hade noga förberett kaffepausen med färdigbredda smörgåsar, bullar och kakor. För några av dem, förstod jag, innebar det ett stort steg att berätta för mig om erfarenheter av döden och hur de själva funderade över sin egen död. För flera var det också första gången de överhuvudtaget talade med någon om sina funderingar kring döden. Det var ofta gripande skildringar av anhörigas döende och död som berättades och som gav upphov till tårar, och uttryck för sorg och saknad. Vid något tillfälle valde jag att stänga av diktafonen och ta en paus då jag förstod att intervjupersonen inte skulle orka fortsätta berätta. Flera intervjuer berörde även mig känslomässigt, och vissa gånger var det svårt att hålla tillbaka tårarna. Andra gånger berättade de intervjuade om döden med glimten i ögat som efterföljdes av skratt och fnissande.

Intervjuerna varade mellan en och två och en halv timme och spelades in med diktafon för att jag skulle få med både vad de sade och hur de gav uttryck för det. Jag antecknade sparsamt under själva intervjun för att kunna fokusera på vad de intervjuade sade. Direkt efter varje intervju satte jag mig däremot i lugn och ro i bilen, på cafét eller på tåget och skrev ner anteckningar om intervjusituationen och de intryck jag fått $i$ en fältdagbok. Bland annat antecknades var intervjun hade genomförts och hur det såg ut där, vad som hade sagts före och efter intervjun, samt under kaffepausen. Många gånger fortsatte vi att prata under kaffepausen, då diktafonen inte var på, eller precis efter intervjun, om framtiden och döden. Några av intervjupersonerna berörde att de känt en viss oro inför intervjun, men att de nu kunde pusta ut. Det som sades när inte diktafonen var på och som hade relevans för studien noterade jag efteråt.

9 av de 26 intervjuerna transkriberade jag ordagrant i sin helhet med skratt och pausar, medan de övriga intervjuerna kom att transkriberas av en professionell transkriberare. Jag har förändrat namnen på intervjupersonerna, och på närstående, städer, platser och andra förhållande som kan knytas till deltagarnas identitet. I översättningen mellan talat och skrivet språk har jag justerat med hänsyn till läsbarhet och förståelse (Kvale \& Brinkmann, 2009). 


\section{Analys- och tolkningsprocess}

\section{Den abduktiva ansatsen}

Analys- och tolkningsarbetet kan sägas pågå från det att studiens upplägg formuleras fram till färdig avhandlingstext. Detta är en process som startar redan då man skaffar sig förkunskap kring de ämnen som ska utforskas (Kvale \& Brinkmann, 2009, s. 120). Med utgångspunkt i läsning av relevant litteratur framkom flera argument som talade för idén att studera vad äldre människor själva har för föreställningar om och förhållningssätt till den egna framtiden, döendet och döden. Varken syftet med studien, urvalskriterier eller de frågor som utgjorde intervjuguiden hade varit möjliga att formulera inför mötet med intervjupersonerna om jag inte hade haft en viss kännedom om fältet genom det redan påbörjade analysoch tolkningsarbetet.

Med utgångspunkt i resonemanget ovan om att analys- och tolkningsarbetet är en pågående process så anammades i denna studie varken ett renodlat deduktivt synsätt (teorier styr forskningen) eller ett renodlat induktivt synsätt (teorier är ett resultat av forskning). I stället är det abduktiva synsättet mer relevant i skapandet av kunskap. Den abduktiva ansatsen i tolknings- och analysprocessarbetet anses vara den förklarings- och förståelsemodell som i realiteten ofta används vid kvalitativ forskning:

Induktion utgår från empiri och deduktion från teori. Abduktionen utgår från empirisk fakta liksom induktionen, men avvisar inte teoretiska förföreställningar och ligger i så motto närmare deduktionen. /.../ Under forskningsprocessen sker således en alternering mellan (tidigare) teori och empiri, varvid båda successivt omtolkas i skenet av varandra. De andra förklaringsmodellerna framstår i jämförelse som mer ensidiga och orealistiska, om man jämför med hur forskning faktiskt bedrivs; annorlunda uttryckt riskerar den som följer dem alltför strikt att sätta tvångströja på sin forskning (Alvesson \& Sköldberg, 2008, s. 56).

Ett exempel på tillämpningen av studiens abduktiva ansats - bland annat har tidigare forskning om äldres framtid, döende och död, liksom Walters (1994) idealtyper av döden fungerat som teoretisk förförståelse och fanns med i studiens upplägg, men som i skenet av empirin - de intervjuades utsagor - successivt har omtolkats. Andra exempel på tillvägagångssättet är de uppdateringar av kunskapsläget - av relevant litteratur - som jag har gjort efter hand i databasen Scopus på sökord som äldre, framtid, döende och död, vilket varit behjälpligt under senare skeden av analys- och tolkningsprocessen (jfr kapitel 2). I analysprocessen har det alltså ständigt skett en ömsesidig växelverkan mellan teori och empiri. 


\section{Den hermeneutiska traditionen}

Det abduktiva synsättet anses också ha beröringspunkter med det hermeneutiska tillvägagångssättet (Alvesson \& Sköldberg, 2008, s. 55). Min studie tar också sin utgångspunkt i den hermeneutiska traditionen (Jensen \& Karlsson, 2001; Ödman, 2007). Hermeneutik betyder tolkningslära där tolkning av det meningsbärande med all mänsklig aktivitet ställs i fokus, ett tolkande av mening som ska leda fram till förståelse av människan. I och med att kunskap är socialt konstruerad så kan den också tolkas på olika vis. En bärande tanke inom hermeneutiken är att delen endast kan förstås ur helheten och helheten endast ur delen. För att jag ska kunna tolka och erhålla en förståelse av intervjupersonernas erfarenheter och föreställningar kring framtid, döende och död (delen), måste också deras erfarenheter och föreställningar ställas i relation till ett vidare kulturellt och socialt sammanhang i både tid och rum (helheten). Det är alltså växelspelet mellan helheten och delarna som möjliggör förståelsen av intervjupersonernas syn på framtid, döende och död, och detta sker i samverkan med forskarens förförståelse. Ödman säger:

Vi har alltid en förförståelse av det vi tolkar. En tolkning utförs vid en bestämd tid och på en bestämd plats av en människa som befinner sig mitt i historien (Ödman, 2007, s. 26).

En annan bärande tanke inom hermeneutiken är diskussionen kring vilken roll forskarens vardagliga och "teoretiska" förförståelse spelar i intervju- respektive tolkningssammanhang. Det vill säga, förförståelse i form av kulturella och sociala värderingar och normer som forskaren införlivar i sin kontakt med det vardagliga livet i tid och rum, och förförståelse i form av "teorier" och aspekter som forskaren införlivar i sin kontakt med sitt forskningsområde. Olika aspekter av förförståelse utgör nödvändiga delar i de tolkningar jag gör som forskare. Förförståelsen är dessutom i ständig förändring, det vill säga, förändringar sker efterhand genom att ny förståelse etableras och gammal revideras. Förförståelse utgör en resurs för forskaren, men kan likväl bli till en belastning om forskaren låter sin förförståelse bli alltför dominant $\mathrm{i}$ arbetet med det empiriska materialet (Aspers 2007, s. 34f, 40, 56; Jensen \& Karlsson, 2001, s. 27; Thomsson, 2010, s. 47f; Ödman, 2007). Likt den abduktiva ansatsen innebär det hermeneutiska tillvägagångssättet att det hela tiden under forskningsprocessen sker en alternering mellan förförståelse och empiri, varvid båda successivt ifrågasätts, justeras, omtolkas och förfinas i skenet av varandra - abduktionen kan säga vara en slags hermeneutisk spiral (Alvesson \& Sköldberg, 2008, s. 59; Ödman, 2007, s. 103f).

Hur förhåller jag mig till ämnet döden och vilken förförståelse har jag 
kring äldre människors framtid, döende och död? Thomsson menar att man aldrig ska förledas tro att en undersökning kan genomföras utan förförståelse. Därför bör ett par frågor ställas, för att förstå hur det egna engagemanget samspelar med det man studerar, till exempel - "Vad har jag läst om det här? Vad har jag för personliga erfarenheter av liknande fenomen?" (Thomsson, 2002, s. 48ff).

Döden har i stort sett varit frånvarande under stora delar av mitt liv. Även om jag har erfarenheter av nära släktingars död, så var det inte förrän vid 24 års ålder som jag för första gången deltog i en begravning. Vi pratade knappast om döden i den närmaste familjekretsen, det var snudd på en total förnekelse. Jag fann i stället andra vägar för att ventilera detta ämne, genom samtal med ett par av mina vänner. Den allmänna hållningen bland anhöriga och vänner var nog, trots allt, att döden var någonting som man inte skulle beröra förrän man var döende, skröplig eller gammal, om ens då. Min syn på ämnet döden, min förförståelse, har emellertid förändrats en hel del varefter arbetet med studien fortskridit. Den här intensiva närheten till döden i form av litteraturläsning, diskussioner med handledare och kollegor, men framförallt i kontakten med de intervjuade, har medfört att min hållning till ämnet döden har blivit öppnare. Både de vardagliga och de "teoretiska" förföreställningarna har alltså omtolkats successivt i skenet av empirin och den framväxande analysen.

Som exempel på tillämpningen av studiens hermeneutiska ansats framkom det $\mathrm{i}$ analys- och tolkningsarbetet av de olika empiriska delarna att ansvar är ett övergripande meningsbärande begrepp. Det är ett begrepp som genomgående återkommer men med olika innebörder för de intervjuade, vare sig det gäller tematiken kring framtid, döende eller död. För att kunna förstå detta övergripande ansvarsbegrepp så måste det också ställas i relation till ett vidare socialt och kulturellt sammanhang i både tid och rum (helheten). Det görs bland annat då det relateras till den teoretiska förförståelsen - Walters (1994) idealtyper av döden där begreppet ansvar betonas, och den vardagliga förförståelsen - och min mera öppna hållning till döden. 


\section{Analys av insamlade data}

I mitt analys- och tolkningsarbete av de intervjuades berättelser har jag arbetat utifrån både den abduktiva ansatsen och den hermeneutiska traditionen (Alvesson \& Sköldberg, 2008; Ödman, 2007). Analys av insamlade data påbörjades redan då ett par intervjuer hade genomförts, dels för att kunna justera intervjuguiden, dels för att relatera analysmaterialet till tidigare forskning och det teoretiska ramverket. När väl samtliga intervjuer var genomförda inledde jag med att läsa igenom det utskrivna materialet, intervju för intervju, och gjorde då anteckningar kring intressanta teman, såväl framträdande som mindre synliga. Jag försökte inledningsvis vara "öppen" för vad materialet hade att säga (Glaser, 1978, s. 2f), och noterade upprepningar, kategorier, metaforer, analogier, likheter och skillnader. Dessutom försökte jag vara uppmärksam på vad som uteslutits, liksom på specifika handlingar, händelser, aktiviteter, strategier, tillstånd, meningar, normer, symboler, grader av delaktighet och relationer (Kvale \& Brinkman, 2009, s 218; Ryan \& Bernard, 2003, s. 89ff). För att kunna identifiera teman ställde jag ofta frågan - "Vad är denna utsaga ett exempel på?" (Ryan \& Bernard, 2003 s. 87). Förutom att härleda teman från materialet genom ett empirinära förhållningssätt - det vill säga utifrån de intervjuades egna utsagor kring erfarenheter, tankegångar och föreställningar gjordes det också genom ett teorinära förhållningssätt - det vill säga utifrån min inlästa teoretiska referensram och mina egna erfarenheter och värderingar (Glaser, 1978, s. 2f; Ryan \& Bernard, 2003, s. 88; Widerberg, 2002, s. 144ff). Jag jämförde även mina nedskrivna teman med anteckningar i fältdagboken, varefter jag läste genom materialet igen, för att kunna sortera det. Dessa teman förekom ofta på flera ställen (delarna) i varje intervjupersons berättelse (helhet). För att komma bort från såväl den deskriptiva nivån som individnivån förde jag samman varje tema från respektive intervju (delarna) till ett antal centrala teman (helheten). Exempel från kapitel 5 är - tidpunkt för tankar om döden och rum som väcker tankar om döende och död. Det är de centrala teman som också har legat till grund för rubriksättningen av studiens fem empiriska kapitel - möten med döende och död genom livet - tankar i vardagen på döende och död - samtal om döende och död-efter döden och tid kvar.

Nästa nivå i analys- och tolkningsarbetet var att utifrån dessa centrala teman identifiera nya mönster och begrepp, det vill säga, lyfta analysnivån ytterligare ett steg. De mönster som framkom i analysen av de centrala temana handlade mycket om kontraster på olika nivåer. Utifrån det centrala temat - tidpunkt för tankar om döden - identifierades till exempel följande två kontrasterande mönster - hög tid att påminnas om döden och döden bör hållas borta (också från kapitel 5). I den fasen av analysen blev växel- 
verkan mellan empiri, tidigare forskning och det teoretiska ramverket också som allra tydligast. Dels genom att jämföra och kontrastera mina resultat mot tidigare relevant forskning. Dels genom att i analys- och tolkningsarbetet relatera till Giele och Elders (1998) nyckelfaktorer, Walters (1994) idealtyper, Kosellecks (2004) begrepp erfarenhetsrum och förväntningshorisont, och så vidare. När mitt arbete med studien nått denna nivå återvände jag ett par gånger $\mathrm{i}$ analys- och tolkningsarbetet av materialet både till de inspelade ljudfilerna och till de ursprungliga transkriberade intervjuerna, för att finna bättre citat, hitta nya infallsvinklar men också för att få mina tolkningar bekräftade. Det var också i den här fasen jag uppdaterade kunskapsläget om äldres framtid, döende och död genom nya sökningar i databasen.

Nästa fas i analysprocessen innebar att utifrån samtliga centrala teman (delarna) identifiera några övergripande teman (helheten). De övergripande temana handlade om - en komplex bild av döende, död och framtid åldersmönster - tredje åldern - det förlängda livsloppet - ansvar - kontroll och värdighet (se kapitel 9). Detta var ämnen som framstod som centrala och som på olika vis möjliggjorde ytterligare förståelse av äldre människors föreställningar om och förhållningssätt till den egna framtiden, döendet och döden.

\section{Etiska överväganden}

Att forska om äldre människors framtid, döende och död är förenat med ett antal forskningsetiska överväganden. För att kunna hantera de eventuella etiska och moraliska överväganden som kan uppstå under arbetsprocessen med studien, valde jag att ta del av de etiska principerna som finns inom humanistisk-samhällsvetenskaplig forskning (Vetenskapsrådet, 2013). Min studie har godkänts av den regionala etikprövningsnämnden i Linköping. Genom att arbeta med denna etikansökan gavs jag i förväg möjlighet att fundera över vilka etiska dilemman som kan uppstå i kvalitativ forskning. Etiska överväganden förekom alltså under hela arbetsprocessen med studien och uppmärksammades redan då jag sökte intervjupersoner till undersökningen. Flera av dem jag vände mig till ansåg att ämnen som död och framtid är svåra att prata om. Men i stället för att mörka, och enbart tala om att intervjun handlade om framtiden och inte om döden, bara för att lättare hitta intervjupersoner, var inte etiskt försvarsbart. Jag har i stället försökt vara öppen med studiens syfte och vara medveten om risken att intervjuerna skulle kunna väcka starka känslor och skapa oro hos intervjupersonerna i och med att teman som framtid, döende och död kunde upplevas som personliga och svåra. Därför var det också angeläget att låta intervjupersonerna lämna sitt samtycke till att delta i studien, vilket ägde rum vid tre tillfällen. Första gången när de po- 
tentiella intervjupersonerna gav sitt samtycke till att bli kontaktade av mig per telefon. Andra gången när jag tog kontakt med dem per telefon. Tid och plats för det muntliga samtycket att delta i studien dokumenterades av mig. Samtidigt avtalades också om tid och plats för intervjun och tillfälle gavs att ställa frågor om studien. Tredje gången skedde det vid intervjutillfället. Ett muntligt samtycke som dokumenterades på detta vis ansåg jag vara mer etiskt gångbart än att erhålla deras skriftliga samtycke, vilket kunde upplevas som mer bindande att fullfölja.

Även vid intervjutillfället gav jag information till de intervjuade om studien och vad som var syftet med intervjun, att materialet från intervjusituationen skulle avidentifieras så att inte någon utanför forskningsprojektet kunde identifiera dem och att materialet endast fick användas för forskningsändamålet. Dessutom fick de upplysning om att medverkan var frivillig och kunde avbrytas vid vilken tidpunkt som helst i processen. Under en av intervjuerna valde jag att stänga av diktafonen då samtalet blev mycket känslosamt, vi tog en paus. Jag märkte efter ett tag att den intervjuade tog upp tråden igen och frågade då om jag kunde slå på diktafonen igen. Hänvisning till externt professionellt stöd - om jag skulle ha gjort bedömningen att sådan behövdes och önskades - skulle ha skett till den församling som intervjupersonen tillhörde, och där jag hade kontaktat en präst eller diakon. Dessa yrkesgrupper har ofta stor erfarenhet av att samtala om existentiella frågor. Ett alternativ till församlingen hade varit att kontakta vårdcentralen. Någon hänvisning till stöd blev aldrig aktuellt. Efter intervjun gavs också möjlighet att ställa frågor kring oklarheter och känsliga frågor, precis som inför intervjutillfället. Om intervjupersonerna ville tillägga eller utesluta något hörsammade jag detta. Efter avslutad intervju lämnade jag mitt telefonnummer och min e-postadress till intervjupersonen, så att de hade möjlighet att nå mig om de ville prata vidare om något som berörde ämnena.

I och med att jag tydligt informerade de intervjuade om deras möjlighet att kunna avböja att delta, avbryta intervjun eller få något parti raderat från intervjubandet, så betraktade jag dessa åtgärder som tillräckliga för att förebygga och minimera risken för att de skulle känna obehag. Jag hoppades även att samtalet kring deras erfarenheter av, föreställningar om och förhållningssätt till den egna framtiden, döendet och döden, skulle upplevas som positivt och värdefullt för dem, trots att det kunde innebära obehag. 


\section{Studiens trovärdighet}

Ett återkommande inslag i diskussionen om den kvalitativa forskningsmetoden handlar om efter vilka kriterier en studies alla delmoment ska värderas. Framförallt reliabilitet och validitet är två kriterier för bedömning av vetenskapliga studier. Reliabilitet - tillförlitligheten i en undersökning - handlar om huruvida slutsatsen från en studie kan bli densamma om en annan forskare genomför studien igen vid ett annat tillfälle. Validitet - handlar om hur forskaren mäter det hon avser sig mäta (Kvale \& Brinkmann, 2009, s. 262ff). Flera forskare menar att de här kriterierna för att bedöma vetenskapliga resultat är tveksamma och olämpliga i kvalitativa sammanhang, att de är mer relevanta i den kvantitativa forskningen. Anledningen till att dessa bedömningskriterier anses olämpliga är att den kvalitativa forskningen inte söker efter en mätbar och en absolut sanning om den sociala verkligheten. "Verkligheten" eller aspekter av "verkligheten" är i stället kontextberoende och mångtydiga (Guba \& Lincoln, [1994] i Bryman, 2009, s. 258).

Medan några forskare förespråkar att de här kriterierna används när den kvalitativa forskningen bedöms, väljer andra att undvika dem och argumenterar för att de tillhör en annan kunskapsteoretisk tradition, eller, så ges begreppen i stället en delvis annan innebörd (Thomsson, 2002, s. 33). Denna studie tar sin utgångspunkt i att de intervjuades syn på "verkligheten" är socialt konstruerad, att flera "sanningar" av de intervjuades syn på döden kan existera parallellt och att det handlar om tolkning och förståelse - den hermeneutiska traditionen - av de intervjuades berättelser. I studien används bedömningskriteriet "trovärdighet", för att kunna bedöma och värdera kvaliteten i kvalitativ forskning (Guba \& Lincoln, [1994] i Bryman, 2009, s. 258). Det handlar om att på ett trovärdigt sätt reflektera, argumentera och övertyga sin läsare om de olika val som görs under arbetsprocessen med studien. DePoy och Gitlin konstaterar att den kritiske läsaren bör ställa två väsentliga frågor vid läsning av en kvalitativt skriven text: "För det första, i vilken omfattning har forskarens personliga bias och personliga perspektiv identifierats och tagits hänsyn till vid dataanalys och tolkningar? För det andra, vilka åtgärder har forskaren vidtagit för att öka undersökningens trovärdighet och noggrannhet?" (DePoy \& Gitlin, 1999, s. 332). I min studie använder jag trovärdighetskriteriet för att eftersträva korrekthet och noggrannhet i studien, vilket innebär att läsaren ska kunna följa processen och bedöma tillförlitligheten i analysen. Ett sätt för läsaren att bedöma analysen är genom relevant empiri, till exempel i form av citat. Trovärdighet inkluderar också en självgranskningsprocess. Det handlar om att vara medveten om och identifiera vilket inflytande min förförståelse och forskarbias kan ha för datainsamling och tolkning. 
Men det innebär även att reflektera över på vilket sätt kunskap har vunnits och vad för kunskap man fått och försöka avgöra hur det har påverkats utifrån mina egna perspektiv (DePoy \& Gitlin, 1999, s. 334).

\section{Intervjupersonerna}

Kapitlet avslutas med en kortfattad, övergripande introduktion av de intervjupersoner som ingår i studien och en förteckning över samtliga intervjuade (se tabell 1). Därefter följer en fördjupad presentation i form av korta fallbeskrivningar av fem intervjupersoner. I avsnittet får presentationen av intervjupersonerna gestalta både hur mångfacetterat deras levda liv kan vara, men även de många beröringspunkter som finns mellan deras levda liv. Presentationen illustrerar även att intervjupersonerna inte utgör någon homogen grupp. Deras livssituation syftar snarare till att framhålla vikten av att livet kan framlevas på väldigt olika sätt vid 70-91 års ålder.

Av de utvalda intervjupersonerna är 15 kvinnor och 12 män i åldersspannet 70-91 år. Den äldsta, en kvinna, är född år 1919 och de yngsta, en man och en kvinna, är födda år 1940. Kvinnorna har en högre medelålder. Samtliga är födda i Sverige, utom en kvinna, som kom till Sverige i 10-årsåldern som finskt krigsbarn. Variationen i de intervjuades civilstånd och familjeförhållande är stor - de är såväl gifta, änkor, änklingar som ensamstående, skilda och sambos, med eller utan barn och barnbarn. 3 intervjupersoner, alla ensamstående, har inga barn, 2 intervjupersoner har barn men inga barnbarn och övriga har sålunda barn och barnbarn, och några även barnbarns barn. Flera av kvinnorna är ensamboende och flertalet av männen är gifta. De flesta framhåller vikten av att umgås med familj, anhöriga och vänner. För flera av dem är de små sociala nätverken viktiga. Samtliga intervjupersoner bor i ordinärt boende i antingen villa eller lägenhet. 10 av de 27 intervjupersonerna är bosatta på landsbygden, medan övriga 17 bor i större städer. Få har bott på samma ort eller i samma stad under hela livet. De flesta har flyttat en eller flera gånger på grund av utbildning, familjeförhållanden eller arbete.

Det är en stor variation i den socioekonomiska statusen bland de intervjuade beroende på social klass, civilstånd och utbildning. Några var uppväxta under ganska fattiga förhållanden, medan ett par kom från välbärgade förhållanden. Majoriteten män har en eftergymnasial utbildning (bland annat som läkare, lärare, socionom), medan några av kvinnorna har en eftergymnasial utbildning (bland annat som sjuk- och undersköterska, förskolelärare, lärare). Flertalet intervjuade har erfarenhet av ett yrkesverksamt liv. Männen arbetade i större utsträckning i tjänstemanna- eller tillverkningssektorn, medan en majoritet av kvinnorna arbetade inom kontor, skola, vård och omsorg. Endast ett par kvinnor var hemmafruar. 
Några, både kvinnor och män, hade också ett politiskt förflutet.

De intervjuade är vid relativt god hälsa, några är dock lite mindre fysiskt rörliga och hör sämre än tidigare, någon lider av reumatism, några känner av en del krämpor. Men det är inte något de lägger större tonvikt vid, just för stunden. Ett par av dem har tidigare under livet drabbats av cancer, en sjukdom som de menar har satt djupa spår i både kropp och själ. Flertalet intervjupersoner har varit föreningsaktiva större i delen av sina liv, och är det fortfarande. Flera hävdar att detta engagemang utgör livsnerven i deras liv. Bland annat är de engagerade i Svenska kyrkan, PRO, politiska partier, fackföreningar och idrottklubbar. Några är dock inte speciellt aktiva föreningsmänniskor. Flera säger att de är mycket fysiskt aktiva och är ute och går minst ett par gånger om dagen, simmar, löser korsord, etcetera. Flera menar också att naturupplevelser är en ynnest för själen. Den betydelsefulla naturen återkommer flera intervjupersoner till då och då under intervjun. De flesta framhåller att livet har varit bra och att de ser ganska positivt på framtiden. 
Tabell 1 Intervjupersonernas namn, kön, födelseår, ålder vid intervjun, civilstånd, familjeförhållanden, geografiskt område och boendeform.

\begin{tabular}{|c|c|c|c|c|c|c|c|c|}
\hline & Namn & Kön & $\begin{array}{l}\text { Födelse- } \\
\text { år }\end{array}$ & $\begin{array}{l}\text { Ålder } \\
\text { vid } \\
\text { intervju }\end{array}$ & Civilstånd & $\begin{array}{l}\text { Barn/ } \\
\text { barnbarn }\end{array}$ & $\begin{array}{l}\text { Stad/ } \\
\text { Lands- } \\
\text { bygd }\end{array}$ & Boende \\
\hline 1 & Asta & $\mathrm{K}$ & 1933 & 77 & Änka & $\mathrm{Ja} / \mathrm{Ja}$ & $\mathrm{L}$ & Villa \\
\hline 2 & Arne & $M$ & 1924 & 86 & Skild & $\mathrm{Ja} / \mathrm{Ja}$ & $\mathrm{L}$ & Villa \\
\hline 3 & Britt & $\mathrm{K}$ & 1931 & 79 & Änka & $\mathrm{Ja} / \mathrm{Ja}$ & L & Villa \\
\hline 4 & Celia & $\mathrm{K}$ & 1924 & 86 & Änka & $\mathrm{Ja} / \mathrm{Ja}$ & L & L-het \\
\hline 5 & Doris & $\mathrm{K}$ & 1932 & 78 & Änka & $\mathrm{Ja} / \mathrm{Nej}$ & $\mathrm{L}$ & L-het \\
\hline 6 & Bertil & $M$ & 1926 & 84 & Ensamstående & Nej/Nej & $\mathrm{L}$ & L-het \\
\hline $\begin{array}{l}7 \\
8\end{array}$ & $\begin{array}{l}\text { Elsa } \\
\text { Carl } \\
\text { Parintervju }\end{array}$ & $\mathrm{K} / \mathrm{M}$ & $\begin{array}{l}1939 / \\
1939\end{array}$ & $\begin{array}{l}71 \\
71\end{array}$ & Gifta & $\begin{array}{l}\text { Ja/ bonus } \\
\text { barnbarn }\end{array}$ & $L$ & Villa \\
\hline 9 & David & $M$ & 1937 & 73 & Gift & $\mathrm{Ja} / \mathrm{Ja}$ & $L$ & Villa \\
\hline 10 & Erik & $M$ & 1940 & 70 & Gift & $\mathrm{Ja} / \mathrm{Ja}$ & $\mathrm{L}$ & Villa \\
\hline 11 & Frida & $\mathrm{K}$ & 1938 & 72 & Änka & $\mathrm{Ja} / \mathrm{Ja}$ & $\mathrm{S}$ & L-het \\
\hline 12 & Fred & $M$ & 1933 & 77 & Gift & $\mathrm{Ja} / \mathrm{Ja}$ & $\mathrm{S}$ & Villa \\
\hline 13 & Gerd & $\mathrm{K}$ & 1940 & 70 & Skild/S-bo & $\mathrm{Ja} / \mathrm{Ja}$ & $\mathrm{S}$ & L-het \\
\hline 14 & Hilma & $\mathrm{K}$ & 1934 & 76 & Änka & $\mathrm{Ja} / \mathrm{Ja}$ & $\mathrm{S}$ & L-het \\
\hline 15 & Göte & $M$ & 1927 & 83 & Gift & $\mathrm{Ja} / \mathrm{Ja}$ & $\mathrm{S}$ & L-het \\
\hline 16 & Hans & $M$ & 1933 & 77 & Gift & $\mathrm{Ja} / \mathrm{Ja}$ & $\mathrm{S}$ & Villa \\
\hline 17 & Inga & $\mathrm{K}$ & 1919 & 91 & Änka & $\mathrm{Ja} / \mathrm{Ja}$ & $\mathrm{S}$ & L-het \\
\hline 18 & Jenny & $\mathrm{K}$ & 1925 & 85 & Änka & $\mathrm{Ja} / \mathrm{Ja}$ & $\mathrm{S}$ & L-het \\
\hline 19 & Karin & $\mathrm{K}$ & 1920 & 90 & Skild & $\mathrm{Ja} / \mathrm{Ja}$ & $\mathrm{S}$ & L-het \\
\hline 20 & Isak & $M$ & 1935 & 75 & Änkling & $\mathrm{Ja} / \mathrm{ja}$ & $\mathrm{S}$ & L-het \\
\hline 21 & Lena & $\mathrm{K}$ & 1925 & 85 & Änka & $\mathrm{Ja} / \mathrm{Ja}$ & $\mathrm{S}$ & L-het \\
\hline 22 & Maja & $\mathrm{K}$ & 1932 & 78 & Ensamstående & Nej/Nej & $\mathrm{S}$ & L-het \\
\hline 23 & Jens & $M$ & 1938 & 72 & Gift & $\mathrm{Ja} / \mathrm{ja}$ & $\mathrm{S}$ & Villa \\
\hline 24 & Nora & $\mathrm{K}$ & 1934 & 76 & Gift & Ja/Nej & $\mathrm{S}$ & Villa \\
\hline 25 & Kurt & $M$ & 1932 & 78 & Gift & $\mathrm{Ja} / \mathrm{Ja}$ & $\mathrm{S}$ & Villa \\
\hline 26 & Malte & $M$ & 1930 & 80 & Gift & $\mathrm{Ja} / \mathrm{Ja}$ & $\mathrm{S}$ & L-het \\
\hline 27 & Olga & $\mathrm{K}$ & 1925 & 85 & Ensamstående & Nej/Nej & $\mathrm{S}$ & L-het \\
\hline
\end{tabular}

Efter denna översikt över de intervjuade följer här avslutningsvis en fördjupad presentation av fem intervjupersoner i form av korta fallbeskrivningar.

\section{Doris 78 år}

Doris är född år 1932 i en mindre ort på den småländska landsbygden där hon också har levt hela sitt liv. Hon är änka och hennes make dog hastigt $\mathrm{i}$ början av 1980-talet under en period då hon själv behandlades för en svårartad cancer. Deras gemensamma dotter var i 10-årsåldern när familjen drabbades. Doris arbetade som kontorist på en verkstadsindustri där även hennes make arbetade. Minnena från den trygga barndomen, de kärleks- 
fulla föräldrarna, och kärleken till dottern verkar ha gett henne kraft i kampen mot den svåra sjukdomen och möjlighet att uthärda förlusten av maken. Under den långa sjukdomsvistelsen på lasarettet pendlade hon mellan hopp och förtvivlan, hennes liv var nära att ta slut, och det tog slut på sätt och vis när hennes make dog. Ensamheten gör sig ofta påmind och någon föreningsmänniska är hon inte. Ibland besöker hon kyrkoförsamlingen, men hon tycks ha mycket god kontakt med sin dotter och hennes man, vilket bidrar till att hon inte alltid känner sig ensam. Tyvärr, och det återkommer hon till, har det aldrig blivit några barnbarn och det saknar hon väldigt mycket. Hon säger att hon är fysiskt aktiv och är ute och går minst ett par gånger om dagen.

\section{Erik 70 år}

Erik är född år 1940 i ett mindre samhälle på landsbygden. Av flera orsaker har han bott på ett antal platser runt om i Sverige, bland annat har arbetssituationen fått honom att flytta. Nu bor han återigen på landsbygden och att få bo nära naturen verkar vara en ynnest för honom. Den betydelsefulla naturen återkommer han till då och då under intervjun. Han är gift, de har tre barn och ett antal barnbarn och hans föräldrar är också i livet. Han framhåller att livet har varit bra och positivt och att han har fått arbeta med stimulerande och intressanta projekt. Barnbarnen sätter guldkant på tillvaron och han ser fram mot att få träffa dem. Han anser sig också ha haft tur med livet. Dels har hälsan stått honom bi, dels har familjemedlemmarna aldrig råkat ut för några svåra sjukdomar eller dödsfall. Naturen får som sagt stort utrymme, en natur som han njuter av och vistas mycket i, men som han också oroas mycket över. Den mänskliga åverkan på naturen har blivit så påtaglig under de senaste åren. Eriks fascination över naturen har kommit under de senaste åren men tycks vara baserad på uppväxten i samhället på den norrländska landsbygden.

\section{Frida 72 år}

Frida är född år 1938 i Stockholm. När barnen hade fötts valde familjen att bosätta sig i en mindre ort på landsbygden. De ville ha nära till naturen. Där levde Frida och maken i 30 år fram till makens bortgång i slutet av 1990-talet. Hon valde då att lämna tryggheten och vännerna och att bosätta sig i en större stad som hon inte hade någon anknytning till. Barnen och barnbarnen som är betydelsefulla för henne bor ett tiotal mil bort. Hennes intresse och engagemang för föreningslivet har emellertid medfört att hon har skaffat sig nya vänner. Dessutom har hon ett antal barndomskamrater som hon regelbundet umgås med och som hon har stort förtroende för. Hon berättar att hon känner sig frisk, och säger samtidigt att det 
är viktigt att hålla sig i gång både i fysiskt och mentalt. Frida har en högskoleexamen i pedagogik, men hon har arbetat med en rad olika projekt som i större utsträckning knutit an till naturvård. Frida tycks alltså vara en föreningsmänniska och hon framhåller att livet känns som bäst då hon får delta i diverse föreningsprojekt och då hon får vara ute i naturen. Det skapar ordning i tillvaron och gör det lättare att hantera saknaden efter hennes bortgångne make. Maken som hon saknar mycket gick bort i Alzheimers och hon upplevde det som kämpigt i slutet av hans liv. En utdragen kamp som varade $\mathrm{i}$ fem år. Hon är glad att de fick vara ett par i över 40 år, men hon nämner att livet inte blev som hon hade tänkt sig. De fick aldrig bli pensionärer tillsammans, aldrig genomföra det som de hade drömt om och planerat.

\section{Göte 83 år}

Göte är född år 1927 i Västsverige. Efter att varit bosatt på åtskilliga orter i Sverige bor han nu sedan en längre tid tillbaka på ostkusten. Göte är gift och de har både barn och barnbarn som de har bra kontakt med. Han är uppvuxen i ett arbetarhem och de politiska ståndpunkter som framfördes i hemmet har präglat hans livssyn. Hans far som arbetade på en kemisk industri tillät honom inte att börja arbeta inom industrin. Han skulle i stället utbilda sig. Han valde socionomutbildningen och därefter fortsatte han att vidareutbilda sig. De politiska och facklig engagemangen tillsammans med den breda utbildningen gjorde att han erbjöds att arbeta med såväl ekonomiska som socialpolitiska projekt på central nivå. Han tycks fundera mycket på varför livet blev som det blev, om det berodde på slumpen, hans målmedvetna fokus eller samspelet mellan dem. Han ägnar även mycket tid åt släktforskning och har skrivit ett självbiografiskt alster, mycket tack vara påtryckningar från barnen att få det nedtecknat men även med inspiration från faderns självbiografiska skildringar. Engagemanget i föreningslivet tar en del tid i anspråk och han har därför börjat fundera på att avsäga sig ett antal föreningsuppdrag. Han är relativt frisk, men börjar känna av en del krämpor.

\section{Olga 85 år}

Olga är född år 1925 i en storstad där hon till största delen av livet har varit bosatt. Hon är ensamstående och barnlös. Hon är uppvuxen i ett välbärgat akademikerhem med en disputerad far. Närheten till universitetsvärlden under barndomsåren tillsammans med de politiska åsikter som genomsyrade diskussionerna i hemmet har i präglat hennes liv. Hon studerade på universitet i Sverige och England och talar fem språk. Under studietiderna i England träffade hon en man som hon förlovade sig med, 
men som omkom tragiskt i en flygolycka. Olga har innehaft ett antal chefsposter och hon har även haft åtskilliga ordförandeskap i ett antal föreningar. Hon är fortfarande mycket engagerad i föreningslivet som hon anser utgör livsnerven i hennes liv. Ett annat intresse är att resa, något hon alltid har gjort och det blir fortfarande ett par utlandsresor varje år. Trots att hon lider av reumatism och ofta har svårt att gå tycks hon alltid ha några inplanerade framtidsprojekt. Något som återkommer varje år och som hon alltid ser fram mot är vistelsen i sommarhuset under ett par månader. Det är en tradition med anor från barndomen att få vistas där med släktingar och en tradition hon hoppas håller i sig ett antal år framöver. Men samtidigt har hon börjat inse att vistelsen på grund av hälsan blir allt svårare att genomföra för vart år som går.

Efter min genomgång av studiens metoder, material och genomförande, samt presentation av intervjupersonerna, kommer jag i de nästa fem kapitlen att fokusera empirin om de intervjuades erfarenheter, funderingar och föreställningar om den egna framtiden, döendet och döden. 



\title{
KAPITEL 4
}

\section{Möten med döende och död genom livet}

\begin{abstract}
Att komma hem till Olga, 85 år, är som att besöka ett museum. Rummet där vi sitter är möblerat med soffa, bord och stolar från den gustavianska epoken, och på väggarna hänger lampetter och en spegel och i taket en kristallkrona, vilka alla härrör från samma tid. Under intervjun sammanfattar Olga en släktkrönika, som sträcker sig från 1300-talet och in i modern tid. Det är som tiden både står stilla och samtidigt rör sig med en oerhörd hastighet. Hon tar därefter fram några gamla fotografier av en släktgård och berättar om sitt allra första minne av döden. Ett möte med döende och död som utspelade sig på släktgården och som hon som tolvåring upplevde som spännande. Olga fick på nära håll i hemmet följa de allra sista dagarna av sin farmors liv och hur släktingarna gemensamt hjälptes åt med den döende farmodern. Efter döden låg farmodern i en öppen kista i trädgården så att alla närstående skulle kunna ta farväl, därefter tågade man upp till byns kyrka, där brutna grangrenar prydde gången fram till kyrkporten, för att hålla en begravningsandakt. Efter akten hölls gravöl. Allt var välregisserat och följde traditionen, något som Olga säger att hon till viss del vill eftersträva för sin egen begravning.
\end{abstract}

I det här kapitlet diskuterar jag intervjupersonernas minnen och erfarenheter av döende och död genom livet. Det jag fokuserar är relationen mellan åldersrelaterade roller, död och historisk kontext, vilket skildrades ovan i Olgas berättelse om sitt första möte med döden, och där det också framkom att det var väsentligt att följa och upprätthålla släkttraditioner, inte minst när det gällde seder och bruk vid någons bortgång. De intervjuades möten med döende och död genom livet är händelser som inträffade vid olika tidpunkter under livet och som utspelades i olika sociala och kulturella sammanhang, där skiftande aktörer medverkade. Kapitlet har en övergripande kronologisk disposition och inleds med skildringar av de tidigaste mötena med döende och död, därefter följer möten med döende och död mitt $i$ livet och avslutas med möten med döende och död de allra senaste åren. De intervjuades berättelser om minnen och erfarenheter av döende och död förstås lämpligast i ett sammanhang av hela deras dynamiska livslopp. I analysprocessen - där jag tog hjälp av Giele \& Elders (1998) nyckelfaktor - har jag intresserat mig för den historiska tid då dessa möten 
med döende och död inträffade och även för de platser som möten utspelade sig på (se även kapitel 2, historisk lokalisering). Intressant var också att analysera de sociala sammanhang i vilka mötena ägde rum och hur och på vilka sätt döden hanterades. Dessa faktorer har hjälpt mig att identifiera ett antal mönster som tillsammans utgör den tematiska strukturen i kapitlet (se nedan). Den forskningsfråga jag diskuterar i kapitlet är alltså - Hur beskriver äldre människor sina tidigare erfarenheter av döende och död?

\section{De tidigaste mötena med döende och död}

Flera av intervjupersonerna inledde med att berätta om sina tidigaste möten med och erfarenheter av döende och död. Några berättade att de i ganska unga år hade kommit $i$ kontakt med döden, medan andra menade att deras första möten med döden hade skett ganska sent $\mathrm{i}$ livet, närmare bestämt i tjugoårsåldern. Det handlar alltså tidsmässigt om årtiondena från 1920-talet fram till och med 1950-talet, när de själva var barn eller ganska unga. Utifrån ett rent idéhistoriskt perspektiv, sett till Walters (1994) idealtyper om synen på döden, så inträffade dessa möten med döden $\mathrm{i}$ övergången mellan den traditionella och den moderna tiden och den tidens synsätt på döden. Det handlade ofta om direkta möten med döende och döda människor, men det var inte heller ovanligt att de intervjuade hade fått sina erfarenheter genom anhörigas berättelser om döende och död under sin barndom. De här tidigaste mötena och erfarenheterna handlade i de flesta fall om intervjupersonernas mor- och farföräldrars bortgång eller om någon annan äldre anhörig från samma generation. Flertalet anhöriga hade således fötts under 1800-talet och hade levt under de sociala och kulturella normer, traditioner och värderingar som då var rådande. I några enstaka fall handlade mötena även om jämnåriga kamrater eller yngre människor som hade dött. De frågor jag diskuterar i detta avsnitt är - Vilka var de intervjuades tidigaste minnen och erfarenheter av döende och död? Var utspelades sig mötena med döende och död, vilka personer var inblandande och på vilka sätt hanterades döende och död? Följande mönster framkom i analysen - döden $i$ hemmet - döden som drama och öppenhet - men också en tystnad kring döden.

\section{Döden $i$ hemmet}

Ett återkommande mönster i de intervjuades berättelser var dödens platser, det vill säga, de beskrev var deras första möten med döende och död hade ägt rum. Det var inte sällsynt att denna kontext hade utgjorts av det egna hemmet, av någon närståendes hem eller i dess närhet. Några berättade: "Förr, då var de ju bara hemma, de var sjuka, de fick dö hemma. De låg $\mathrm{i}$ ett uthus i kistan, hemma, /.../ allt skedde i hemmet då" eller "det var så 
påtagligt att de skulle bara ligga hemma och skötas av de sina där" (jfr Bringéus, 2007). Det var i de flesta fall i en välbekant miljö som de intervjuade hade fått erfarenheter av döden och samtidigt i en omgivning där de nästan dagligen hade vistats under sin barndom. Dödsfallen hade inneburit att hemmet för en tid förvandlades till en slags scen som laddades med symboler och ny rekvisita, som till exempel med vita lakan som spändes upp i uthusen, grankvistar och enris som lades på trappan, kistor som ställdes upp på bockar, häst och vagn som tog den döde till den sista vilan. Andra synliga tecken på denna scenförändring var exempelvis svarta kläder, sorgflor och sorgeband som anhöriga bar under en längre tid. Någon nämnde angående de svarta kläderna: "När min mormor då gick bort, som det var på den tiden, så gick ju mamma klädd helsvart ett halvår och sedan lättade hon upp med lite vitt, svart med vita blommor eller någonting sådant där". Dessutom hade hemmet fått gäster och besökare och dragit till sig byinvånarnas blickar. Detta utspelade sig under en historisk tid då "det skulle visas utåt att man hade lik i huset" (Skarin Frykman, 1994, s. 93) och där begravningar av tradition många gånger skulle manifestera den ekonomiska förmågan hos familjen (Åkesson, 1997, s. 90).

Det var inte ovanligt att mor- och farföräldrar fick sluta sina dagar i hemmet, omgärdade av familjemedlemmar, släktingar och vänner. När den anhörige hade dragit sitt sista andetag hade hon eller han gjorts i ordning, oftast i den avlidnes egna hem. Den döde hade sedan fått ligga i en öppen kista i hemmet, i uthuset eller i trädgården så att man hade möjlighet att se henne eller honom och ta ett farväl:

Nora, 76 år, var i tioårsåldern när hennes mormor dog och hon fick åka och ta ett sista farväl. Det visade sig att mormodern låg i en öppen kista i sitt hem med släktingar och vänner samlade runt kistan sjungandes sånger och psalmer. Det var en gammal hälsingetradition att sjunga ut den avlidne på detta vis. Nora berättar: "Och sedan skulle man gå fram och säga adjö och sådant där så att det var lite skrämmande för att min mamma hörde inte till dem som berättade före vad som skulle hända. Så att, det kom överraskande liksom att: - Gå nu in och säg adjö till mormor!

Den här förändringen av hemmet från det normala till den avlidnes sista utpost före begravningen mindes några av de intervjuade som något vackert och rogivande att ha fått ta del av. Men det fanns andra som inte hade uppskattat förvandlingen av hemmet, som i stället upplevde att hemmet hade blivit väldigt mörkt, svart och dystert efter dödsfallet.

En plats som i alla tider brukar förknippas med döden men som däremot inte förekom så ofta i de intervjuades berättelser var möten med döden i kyrkor och på kyrkogårdar. Någon intervjuad mindes att "det var 
rätt långdragna begravningar i kyrkorna. Prästerna höll på och försökte suga ut så mycket som möjligt, ja, men det blir nästan lite skräckinjagande på något sätt. Lite mystiskt, kanske mycket beroende på det här kristna då”. Asta, 77 år, berättade om en begravning som hon egentligen inte skulle ha deltagit $i$, och som, i kontrast till dåtidens norm att visa att det hade inträffat ett dödsfall i familjen, i stället skulle ske i det tysta, med anledning av att det handlade om självmord:

Grannfrun i lägenheten bredvid Astas familjs hade gasat ihjäl sig och hon hade också tagit med sina tre barn in i döden. Barnens pappa som befann sig i ett tillstånd av förtvivlan hade bett Astas föräldrar att närvara vid begravningsceremonin. Asta minns alltför väl att kyrkan i det närmaste var tom under ceremonin och att pappan förmodligen hade bett dem delta för att han inte ville att avskedet skulle ske inför tomma rader. För Asta blev begravningen en fasansfull upplevelse. Mitt på kyrkogolvet stod fyra vita kistor, varav tre var mindre och en av dessa mätte knappt en meter.

Det var inte alltid som dödens platser hade utgjorts av kyrkliga miljöer eller av välbekanta hem. Några intervjuade hade erfarenheter av oväntade och brutala sammanhang som bröt mot normer, traditioner och manifesterandet av den ekonomiska förmågan hos familjen. Ett par av de intervjuade nämnde att de under sin barndom hade bevittnat några, som de sade, "hemska" möten med döende och död:

Erik, 70 år, berättar att det var absolut förbjudet att leka på sågverkets område. Men samtidigt fanns det ju inget roligare än att vara där som barn. Maskiner att klättra på, hoppa i spånhögar med mera, men det fanns ett farligt ställe och det var inhägnat. Det var där de dränkte timmer inför sågningen och där bildades det alltid en flytande barkhinna, så att det var precis som om det var ett golv istället för bara bark. Någon hade dock glömt att stänga grinden den dagen och när de kom in där och lekte så klev kamraten rakt ut på barkhinnan och drunknade. Erik och hans kompis hade sedan klättrat upp på en bänk som fanns intill statarlängan där de bodde och stått och kikat in genom fönstret på kamraten som låg död på diskbänken.

Hilma, 76 år, som är född i Finland berättar om sina allra första minnen av döden. Det var möten med döden som utspelade sig under andra världskriget när finska stupade soldater i fortsättningskriget mot Sovjetunionen kom hem till Finland i lådor: "Det var nog det första som jag har upplevt. När det där hemska hände".

Det privata hemmet var ofta den plats där de intervjuade som barn och unga hade mött döende och död. Hemmet blev en betydelsefull plats för en tid när de kollektiva ritualerna kring döende och död ägde rum där, 
och en plats som gav utrymme åt både liv och död. Det var också i den sociala och kulturella miljö som det privata hemmet utgjorde, som de intervjuades förhållningssätt till döden tog sin början och formades.

\section{Döden som drama}

Ett annat mönster handlade om det sociala sammanhang där de intervjuades allra första möten med döende och död hade utspelats. Några mindes att anhörigas och vänners döende och död hade skakat om tillvaron för den enskilda människan och för omgivningen i stort. Mitt i detta kaos tycktes det trots allt ha funnits en slags kollektiv beredskap - vana och rutin som byggde på tidigare generationers tradition att handskas med döden - som nu kom till användning (jfr Walter, 1994).

På något vis hade flera av de intervjuade upplevt mötena i hemmen med anhörigas döende och död som något slags drama. Närmare bestämt, de intervjuade hade varit åskådare medan deras närstående hade utgjort aktörer som hade hanterat situationen och som hade haft allt ansvar vid dödsfallen. Bland andra Bertil, 84 år, mindes hur han på avstånd hade följt ritualerna vid sin farmoders död: "Jag gick där utanför och tittade på det och så råkade jag vissla, och då sa min mamma, - Huu Bertil, vissla inte i dag!". Erik, 70 år, kom ihåg att "vi lekte ju då, fortsatte att leka dagen efter [dödsfallet]".

Förutom att de intervjuade själva mindes hur de hade iakttagit dramat på avstånd så mindes de också anhörigas och grannars engagemang kring dödsfallen: "Alla var engagerade naturligtvis". Var och en i omgivningen hade en roll i detta drama. Några intervjuade nämnde just den tradition där några av byns invånare hade fått till uppgift att iordningsställa den avlidna innan den döda kroppen skulle placeras i en öppen kista. En av dem sade: "Det var ju någon tant i byn där som hade gjort det, klätt henne [farmodern]" (jfr Bringéus, 2007, s. 267; Åhrén Snickare, 2002, s. 125ff), och "tanten" skulle också se till att det fanns en bibel placerad på den dödes bröst med dennes händer ovanpå. Vissa anhöriga hade fått till uppgift att baka och laga mat inför gravölet och några hade fått uppdraget att inhandla en kista i staden. Bertil, 84 år, berättade om den kollektiva beredskap som hade funnits att tillgå då en närstående hade dött: 
Grannfolket involverades i hans farmors död, och han nämner att det var framförallt gummorna som hjälpte varandra på den tiden. Uppgifterna bestod bland annat i att klä utomhusboden med vita lakan och sedan transportera den döda dit ut så att hon kunde ligga där på en bår tills en kista hade köpts. Sedan hjälptes de åt att servera kaffe till gästerna innan de skulle gå ut och se den öppna kistan och ta ett sista farväl innan locket skruvades på. Sedan ordnade man med färden till kyrkan, med två svarta hästar och likvagn och gästerna fick åka buss. Och därefter hem igen till middagen.

De intervjuade hade som barn och ganska unga upplevt detta drama på mycket olika sätt. Några intervjuade gav uttryck för att dödsfall hade gett upphov till starka känslor:

Så att jag tyckte det var vackert och, ja, att man blir berörd känslomässigt, det var liksom bara att hon hade ju fått ro, hon hade fått en hög ålder, det skulle bara vara slut.

Jag var 6 år och min farmor låg i sin kista, och hon låg där bara som hon sov, jag ser allting framför mig. Det är ett starkt minne jag har /.../ där stod kistan och där låg hon klädd och fin.

Är man en grabb i 11-12-årsåldern var ju döden en skräck.

Andra konstaterade i stället: "Inget av de [dödsfallen] var väldigt ångestladdat, men det hade ju med det att göra att de blev så pass gamla" och "ja, jag var självklart inte oberörd av det men det var ingen djup sorg utan det var bara att konstatera att så här är det, livet går vidare". Döden i sig hade ändå upplevts som något obegripligt och ohanterligt för de intervjuade:

Det här med dödsfallet då, vilket jag inte begrep så mycket, men...

Men när man är barn och tonåring och ung så funderar man inte så mycket på om döden ser ut si eller så. Man har ingen uppfattning om det då. /.../ [Döden ansågs som] väldigt långt bort och det gäller inte mig, det, på något sätt.

När jag var 9 år så var det ju inte alls så utan då sprang man ifrån det, begränsad livserfarenhet [av döden] så det fanns inte så mycket att bygga på heller. 
Döden kunde vara skrämmande, spännande och obegriplig för dem när de som barn och unga mötte den. Döden sysselsatte också ofta ett kollektiv av närstående som tillsammans genomförde ritualerna, och där de intervjuade följde händelsen - detta drama - på håll. Det var i de här sociala sammanhangen, i mötet med döden, som värderingar, traditioner och normer kring döden så smått började prägla de intervjuade och deras förhållningssätt till döden.

\section{Öppenhet, men också en tystnad kring döden}

Ytterligare ett mönster handlade om på vilket sätt anhöriga och vänner i de intervjuades omgivning hade hanterat döden. Några framhöll den öppenhet som hade funnits kring döden på den tiden, det vill säga, att döden hade synliggjorts i vardagslivet och flera mindes även att närstående hade pratat om döden ganska ofta under uppväxttiden. Först och främst, konstaterade några intervjupersoner, medförde iordningställandet av den döde i hemmet att man på den tiden fick möjlighet att se en död människa: "Då fick man ju se dem i alla fall, när de var döda" och "på det sättet var man ju mer van vid det [döden]" (jfr Walter, 1994). Några menade också att de inte upplevde det som problematiskt att prata om döden: "Ja, det hade jag definitivt [möjligheten att samtala med någon]" och "vi pratade ju om det här väldigt mycket i syskonskaran när vi växte upp". Det hade också funnits flera situationer i vardagen där samtalen kring döende och död hade möjliggjorts. Vid sådana tillfällen var det vanligtvis de närstående som pratade med varandra medan intervjupersonerna snappade upp ett och annat vid de här samtalen. Några mindes att deras anhörigas tro många gånger hade lett till samtal om döden. En av dem nämnde: "Alla mina fastrar och de var religiösa allihopa /.../ så att det pratades väl om att de kom upp till himlen och sådant där". En inte ovanlig situation var också att de anhöriga efter sina gudstjänstbesök i kyrkan eller på väckelsemöten i Missionsförsamlingen berättade om Gud den allsmäktige och döden:

Bertil, 84 år, minns att hans farmor efter sina besök på väckelsemöten ofta omnämnde att predikanten hade basunerat ut att människan skulle vara förberedd inför döden. Bertil kommer ihåg att han hade frågat: - Att vara förberedd inför döden, hur då? Det var med andra ord betydelsefullt att ha sin sak klar med Gud inför den förestående döden. Bertil minns varken om farmodern hade hunnit förbereda sig eller om hon hade tillkallat prästen för att få ta nattvarden, som inte var ovanligt på den tiden när någon låg inför döden. 
Några intervjuade mindes också att döden hade fått stort utrymme vid dödsfall i den lilla byn. "Det var ett stort ämne var gång det hände, det var det överhuvudtaget när det var någonting som bröt enformigheten, så gav ju det upphov till att kaffekonsumtionen steg." Av tradition var det vanligt att "de gick till varandra och ventilerade det här då", berättade ett par av deltagarna. Tidsandan, menade några, hade varit sådan på 1930-40talen att byns invånare gjorde en stor affär av döden men att de samtidigt tog "lättare på döden eller såg mera nyktert på döden".

Det var inte enbart i samband med dödsfall som döden var ett aktuellt ämne. Några nämnde också att under barndomen kunde äldre släktingar skrämma dem genom att exempelvis påstå att det spökade i huset och att döda människor kunde uppträda som gengångare: "Jag upplevde döden framförallt på skrämselsidan". Det hade påverkat vardagslivet då och då för några av de intervjuade:

Bertil, 84 år, och hans syskon undvek exempelvis att gå i närheten av de nyligen dödas hus. Det innebar att de fick ta omvägar för att gå hem för att de visste ju aldrig om de skulle stöta på den döde. En dag hade hans broder kommit hem storgråtandes, och anledningen var att han hade sett en kvinna som påminde om den döda farmodern vid huset där hon hade bott när hon levde.

I några berättelser om de allra första mötena med döende och död framkom en tydlig öppenhet från omgivningens sida när det gällde hanteringen av döendet och döden. Det vill säga, deras anhöriga hade inte gömt undan döden, de hade i samband med en släktings död i stället låtit barnen få delta i samtalen kring döden.

I kontrast till den öppenheten gentemot barnen fanns det andra intervjuade som inte fått sådana erfarenheter av döden under sin barndom. För dem hade döden varit frånvarande under uppväxten. Döden skulle varken få inkräkta på vardagslivet eller komma innanför hemmets dörrar. Det ansågs framförallt inte lämpligt för de yngre generationerna att få ta del av de äldres funderingar och samtal om döden. Döden och dess attribut gömdes undan. Någon nämnde till exempel att "svarta kläder var det värsta hon [mamman] visste" därför förvarades de "på vinden, [och fick] bara användas vid begravningar".

Några samtal om hur anhöriga ville ha det $\mathrm{i}$ livets slut hade det heller aldrig blivit. En intervjuad sade: "Nej, nej, nej. Nej, nej, ingen. Ingen. Inte alls. Hade aldrig pratat om det ens en gång. Ingenting!" En annan deltagare nämnde: "Nej, nej, det kunde vi inte prata om. Jag tror att de äldre då som gick bort, de ville nog inte prata om döden". Döden hade sålunda enbart mötts av tystnad och några menade också att de som barn skulle skyddas mot att vistas i dödens närhet, ta del av dödens ritualer eller be- 
höva lyssna på samtal om döden - "föräldrarna skyddade, det var en annan tillvaro [än i dag]" och "jag skulle liksom skyddas från att gå med på begravningar". Några av de andra deltagarna var inne på samma linje:

Gerd, 70 år, berättar att när hennes morfar var döende i magcancer på sjukhemmet så förbjöd hennes mor henne att besöka honom, och när han senare avled fick hon inte ta farväl på begravningen. Gerd var då i tioårsåldern. Anledningen, menade Gerd, var att hennes mor hade blivit moderslös vid tioårsåldern och modern hade sedan dess tyckt det var förfärligt att prata om döden, gå på begravningar, bära svarta kläder och ville på så sätt skydda henne från att ta del av detta. Gerd och hennes mor pratade heller aldrig om faderns död eller den tid de inte fick tillsammans. Det som framhölls var i stället att de fick vara tacksamma för den tid som har varit.

Även Erik, 70 år, minns att ett dödsfall på skolan aldrig ledde till att skolans personal pratade om det: "Det verkar inte så, jag kommer inte ihåg att det var någon som gjorde det. Att det var någon som tog upp, inte i skolan eller någonting. Vi hade ju en som begick självmord som gick på skolan, hoppade ifrån fabrikstaket, han var ju inte mer än kanske, ja, jag tror han gick i sjuan eller i åttan. Då var det lite snack men skolan blev ingen samlingsplats eller man tog aldrig upp det, aldrig att någon pratade om döden".

Som framkommit, hanterades döden under de intervjuades uppväxtår på varierande sätt av omgivningen. Å ena sidan beskrevs en öppenhet där de som barn fick bekanta sig med döden. Å andra sidan var döden något att skyddas från och där fanns inte något utrymme för barnens oro och ängslan. De intervjuade formades snarare utifrån ett synsätt som gick ut på att döden inte borde ingå i deras erfarenhetsvärld.

\section{Möten med döende och död mitt i livet}

När de intervjuade hade berättat om sina far- och morföräldrars bortgång fortsatte flera att berätta om sina erfarenheter av föräldrarnas döende och död. Ibland handlade de här minnena även om en livspartner, syskon eller kusiner som hade dött. Tidsmässigt överensstämde flertalet av deras erfarenheter med tidsperioden från 1950-talet fram till och med 1980-talet. Det var en tid då de intervjuades egen livssituation ofta hade omfattat familj, barn, utbildning och yrkesliv - med andra ord, de befann sig i vuxenlivet. Med utgångspunkt i ett idéhistoriskt perspektiv, sett till Walters (1994) idealtyper om synen på döden, så inträffade mötena med döden nu under den moderna tiden med dess syn på döden. De frågor jag diskuterar i avsnittet är: Vad har de intervjuade för minnen och erfarenheter av döende och död som de har upplevt senare under livet? Var utspelades dessa 
möten med döende och död, vilka personer berörde de och på vilka sätt hanterades döende och död? Följande mönster framkom i analysen institutionen som dödsplats - en förändrad roll vid närståendes död - en tilltagande tystnad.

\section{Institutionen som dödsplats}

Det framkom att dödens platser hade börjat ändra karaktär under den här perioden i de intervjuades liv. Hemmet utgjorde inte längre den plats där döden inträffade och där döden hanterades av de anhöriga. I stället började mötena med döende och döda närstående allt oftare utspela sig $\mathrm{i}$ sjukhusmiljöer eller på ålderdomshem. Det ligger i linje med var döden till stora delar ägde rum och var döden hanterades under den moderna eran (Walter, 1994, s. 47f). Det var på dessa platser den "naturliga" döden skulle utspelas (Alvsvåg, 1985, s. 25). Ett inte ovanligt påstående var: "Han dog på sjukhuset" och "mina föräldrar som låg på långvården". I dessa miljöer hade de intervjuade tagit farväl, långt ifrån hemmet. Några av de intervjuade sade sig inte minnas att de hade upplevt institutionerna på något särskilt vis. Andra, däremot, berättade att de upplevt de här mötena med döende och död - vilka utspelade sig i sterila och kyliga korridorer och undersökningsrum med "slangar och hela baletten" - som ogästvänliga, skrämmande och svårhanterliga. Anledningarna tycktes ha varit flera. Miljön, upplevdes inte sällan som en slags dödens platser dit den anhöriga hade kommit och dött och som en plats för avsked dit de intervjuade helst hade velat undvika att komma. Samtidigt som flera intervjuade hade känt en motvilja inför besöken på de här institutionerna, hade de även känt sig ovälkomna när de ville återse sin käraste eller vän. Några berättade: "Men tror du att jag fick gå in till min man. /.../ Nej, varför släpper de inte in mig?", och "det var väl inte så vanligt att man, och förresten, jag undrar om man fick ta med sig ungar på 70-talet, om de fick gå, jag tror inte de fick besöka sådant". Andra upplevde att institutionernas "funktion" omöjliggjorde för dem att vara nära sina anhöriga, och någon konstaterade att "man separerade ju detta väldigt effektivt".

Institutionerna var platsen där avsked av döende eller döda anhöriga hade ägt rum. Det var också de här platserna och miljöerna i denna livsfas, som kom att prägla deltagarnas förhållningssätt till döden.

\section{En förändrad roll vid närståendes död}

Intervjupersonernas egen roll vid döende och död ändrade med tiden karaktär. Det handlade inte längre om ett socialt sammanhang där de var åskådare till ett drama. I stället hade de intervjuade alltmer kommit att inta och ibland pådyvlats rollen som aktör i dessa situationer. Varför? De 
var inte längre barn eller ungdomar, de befann sig "mitt i livet", de var vuxna och den livsloppsmässigt förväntade rollen var att de skulle vara aktiva när ett dödsfall inträffade. Det hade alltså ytterligare tillkommit en dimension i mötet med döende och död. Flera av de intervjuade ansåg att de under denna del av livet hade större förväntningar på sig att vara aktiva i mötena med döden. Någon påpekade:

Det är också många praktiska bekymmer, begravas och arvskiften och sådant så att det är inte bara att du sitter och hänger utan att du bokar tider, vad som ska ske så att det fyller ju en viss del av min dag, men det var mycket svårt alltså.

Döendet och döden skulle sålunda hanteras både praktiskt och känslomässigt av just dem. Beslut togs, vare sig de intervjuade ville det eller inte, antingen av dem själva eller i samråd med andra anhöriga. Det kunde gälla allt från praktiska detaljer rörande begravningar eller ansvar för ett dödsbo, till att vaka vid den döendes säng. Mötena med döende och död tycktes ha blivit en angelägenhet som ställde dem inför nya sociala, kulturella, existentiella och religiösa utmaningar och som också krävde en rad överväganden. En intervjuad berättade att vid moderns död hade det funnits åtskilliga beslut att överväga:

Jag tänker på min mamma, hon var förvirrad de sista åren, det märkte jag ju då. Hon som hade varit så ordentlig, vilken otrolig röra det var på allting och jag ordnade ju begravningen och psalmer och så, som jag trodde hon ville. Två år senare så råkade jag bläddra igenom gamla Bibeln, där låg ett papper med psalmer hon ville ha. Ren tur att jag hittade det för att det låg instoppat så där liksom. Men det var så dags.

Den nya rollen och ansvaret - att vara delaktig i hanteringen av närståendes döende och död - upplevdes på mycket olika sätt. För flertalet hade dödsfallen inneburit stor sorg och saknad medan några menade att dödsfallen dessutom inneburit att vardagsrutinerna hade förbytts till kaos. Att vara mitt uppe i livet med arbete, barn, och samtidigt vid denna tidpunkt i livet mista föräldrar eller den egna livspartnern hade varit en ofattbar upplevelse. Några av dem berättade att: "En kunde inte fatta", "en hade ju aldrig kunnat tänka det" och "det var väl det som var lite chock om jag säger, att jag hade varit dagen före och gratulerat henne och sedan dagen därpå så [var hon död]". Föräldrarna hade alltid funnits där och livspartnern skulle finnas där för all framtid, menade de som hade blivit drabbade. Några beskrev en upplevelse av att en bit av dem själva hade försvunnit i samband med föräldrarnas bortgång. De hade visserligen varit medvetna om att föräldrarna var gamla och i vissa fall skröpliga, men de 
hade ändå inte varit riktigt förberedda. Tidigare studier visar att många människor, oavsett ålder, känner sig övergivna när deras föräldrar dör, och att föräldrarna i hög grad utgör en del av den egna identiteten (Ekvik, 2005, s. 13f). Några intervjupersoner mindes att de hade reagerat starkt, några hade blivit deprimerade. Att ha ansvaret för de avgörande besluten som rörde död eller begravning hade varit svårt. Bertil, 84 år, mindes att han hade tagit sin mors död ganska hårt och att han även hade blivit deprimerad. Han var vid dödsfallet bosatt $i$ en annan del av landet och avståndet hade varit till en viss hjälp för honom:

Jag jobbade ju i Värmland då och det gick bra hela tiden där uppe tills jag kom hem hit dagen före begravningen och såg att det var verkligt, det var så tryggt där uppe i Värmland, utan nu kom jag ner här och nu var jag mitt inne i smeten så att säga. Så att, det var svårt, både begravningen och efteråt...

Även Inga, 91 år, mindes hur hon hade känt sig vid sin makes bortgång:

Ja, min mans begravning, men då är man så upptagen av sig själv, då är man ju inte med. Faktiskt. Jag tror inte jag nästan kommer ihåg, för, man vill sudda ut det på något sätt. Ja, man suddar ut det, därför att man vill inte att det ska ha hänt. Och då så, ja, det var också en märklig begravning. Men, ja, då är man liksom bedövad. Man är inte där. /.../ Det var, nej, jag kommer bara ihåg det som en dimma.

Å andra sidan menade några att de, trots sorgen och saknaden vid dödsfallet, snarast hade känt ett behov att få ta ansvar, få bestämma och se till att deras anhörigas önskningar blev uppfyllda. Förhållningssättet till föräldrarnas döende eller död hade ändå oftast varit att gamla människor dör, åldern hade tagit ut sin rätt. En intervjuad berättade rätt krasst och utan sentimentalitet: "Jag vet att morsan och farsan dog men det är väl inget speciellt med det. De skulle ju dö". Men när föräldrarna hade dött hade det blivit mycket arbete och frågor att ta ställning till. Även Olga, 85 år, beskrev detta åtagande på följande vis:

När pappa gick bort då fick jag ju försöka sköta det mesta och det är väldigt mycket praktiska saker kring begravningar och sådant där. /.../ Och det var väldigt mycket för mig att stå i så att det var rätt nyttigt. Och jag vet när min bror, ja även sedan då, det är mycket bra att man har någonting att göra när något sådant där händer. Det är mycket bättre, sorgen finns där och den kommer fram mycket mer efteråt, men har man full sysselsättning så klarar man sig mycket bättre. 
Det är ett mönster som ligger i linje med tidigare forskning: "Det är välkänt att de praktiska bestyren med att ordna en begravning i många fall har en lindrande funktion för de sörjande. Tomrummet efter den döde fylls under några hektiska dagar med planering av begravningsarrangemanger" (Åkesson, 1997, s. 80).

Ytterligare en ny aktör hade dykt upp i hanteringen av närståendes döende och död vid den här tiden. Det som flera intervjuade åsyftade var vård- och omsorgspersonalens framträdande roll. Några mindes att "personalen var fantastisk". Andra mindes snarare upplevelsen av att personalens sätt att agera hade begränsat de intervjuades praktiska och känslomässiga utrymme inför den döda. Några sade: "För att min man, det var andra som tog hand om honom, det var ju - Åk hem med dig! så var det på den tiden", och "läkarna talade inte om för den cancersjuke att den hade cancer utan då gick man ju till några anhöriga och berättade och så var det hysch, hysch". Att sjukvårdspersonalen inte talade direkt med patienten framkom då och då i de intervjuades berättelser (jfr Walter, 1994), liksom respekten för den medicinska expertisen:

Celia, 86 år, berättar om hennes makes bortgång i mitten av 1960-talet. Hon kommer ihåg det kyliga mottagandet som hon och hennes son fick på sjukhuset och den långa väntan i korridorerna på att få träffa sin make igen. De fick dock aldrig se honom igen. Hon var frågande inför varför läkaren inte hade låtit henne och sonen besöka maken och ta ett sista farväl. Celia konstaterar: "Du vet, man var ju så ung, så man sa ju inte så mycket på [den tiden]. Hade jag haft det kurage som jag har i dag och de erfarenheterna, så hade jag varit inne hos min man alla gånger, då tordes man inte säga någonting /.../ jag hade inte det kuraget så att jag kunde stå emot dem, [läkarna och personalen] att de skulle släppa in mig...".

De intervjuades berättelser påminde mycket om den kritik som sjukvårdens sätt att ta ansvar för döende människor fick på den tiden. Det sades bland annat att: "Samhället bekämpar döden, och kämpar med alla rådande medel". Döden ansågs inte längre vara patientens angelägenhet utan enbart läkarens. Patienten miste rätten att själv inneha huvudrollen vid sin egen död (Alvsvåg, 1985, s. 25ff).

De intervjuade upplevde under denna livsfas att möten med döende och död innebar en annan roll i förhållande till den de hade haft tidigare i livet. Nu handlade det i stället om förväntningar, normer, rättigheter och skyldigheter som förknippades med deras åldersrelaterade roll i vuxenlivet. I rollen ingick att ta ett större ansvar. Ansvaret var inte längre fördelat på ett kollektiv, det fanns ingen kollektiv beredskap och knappast några gemensamma ritualer. Ansvaret delades i stället mellan dem som anhöriga och experterna - sjukvårdspersonalen. Dessutom, paradoxalt nog, 
verkade avståndet till den döende och döde ha ökat, det fanns inte någon "närhet" längre, trots att ansvaret upplevdes som större än tidigare under livet.

\section{En tilltagande tystnad}

Den moderna tidens syn på döden förknippas ofta med ett slags undanträngande, där döden hade gjorts till något främmande som man förträngde och nekade att förlika sig med (Alvsvåg, 1985; Walter, 1994). Detta sätt att hantera döden ligger i linje med det som framkom i de intervjuades berättelser. En vanlig bild av döden vid den här tiden i de intervjuades liv var att man sällan pratade om döden. Antingen fanns det inte något behov av att samtala eller så ansågs det som ett ämne som var svårt att tala om. Några intervjuade menade: "De pratade nog inte så mycket om sådant på den tiden, nej". Döden "det var bara ett konstanterande" och "vi ville sopa sådant under mattan". Några nämnde också att vänner, men även anhöriga, hade upphört att höra av sig då deras föräldrar eller livspartner hade varit döende eller hade dött, och hur besvärligt de hade upplevt det vara att inte få dela sina funderingar om döden med någon. För några som hade mist sin livspartner hade den första tiden som änka inneburit att de nästan förlorat hela sitt sociala nätverk. Några bekanta hade kanske ringt några få gånger men sedan hade det förblivit tyst. En av de intervjuade menade: "Att jag blev nog kanske bland de första som blev änka i den här åldern ... så att det var ju lite jobbigt", framförallt på grund av inte någon av de andra vännerna i den generationen var änka. Omgivningen hade inte vetat hur de skulle förhålla sig, menade en intervjuad, och några av dem som tidigt $i$ livet hade blivit änka/änkling visste inte heller riktigt hur de skulle agera gentemot omgivningen: "Men jag delgav aldrig mina tankar". Flera intervjuade nämnde också att deras närstående aldrig hade planerat eller förberett någonting inför döden. Någon sade: "Men mor ville inte prata om det. /.../ Jag upplevde det som att de hade inte sig emellan pratat igenom det här [om hur föräldrarna ville ha det i livets slut]". Celia, 86 år, mindes att hon och hennes make knappast alls pratat om önskemål inför döden: "Det var eldbegängelse, och det var ju rätt nytt på den tiden, det var inte vanligt på 60-talet. Det var det enda jag visste om min man och döden, men det visste jag". Somliga hade alltså upplevt att de stått där bokstavligen handfallna och inte vetat något, eftersom önskemål om speciella arrangemang inte hade uttryckts. Vissa menade att det hade underlättat för dem som efterlevande medan andra beklagade avsaknaden av vägledning. De intervjuade hade velat vara tillmötesgående. Britt, 79 år, förklarade: 
Därför att ingen, av mina släktingar och föräldrar eller de pratade inte om någonting, så man stod ju och visste inte vad de hade önskat. Och det tycker jag är ganska tråkigt. För man skulle ju vilja tillmötesgå dem på den sista biten.

I stället hade det ofta blivit så att de intervjuade hade utgått från rådande normer då de skulle ta diverse beslut. Någon nämnde bland annat att det hade tagits för givet att begravningsakten skulle ske i hemförsamlingen i Svenska kyrkan eller att det rådande gravskicket i byn även skulle tillämpas på den avlidne - och så hade det också blivit. En anledning till att de inte hade vetat någonting om föräldrarnas önskemål inför döden var att det talades mycket litet om döden i hemmen. Dessutom hade de aldrig frågat efter föräldrarnas önskemål. Föräldrarna hade kanske inte velat oroa barnen med sina funderingar och önskemål och barnen hade inte heller frågat. Detta undvikande av samtal om döden gick som en röd tråd genom vissa av de intervjuades generationer - såväl mor- och farföräldrar som mödrar och fäder hade undvikit prat om döden.

Först när en närstående drabbades av obotlig sjukdom eller avled kunde det bli aktuellt att prata, men ibland inte ens då:

Arne, 86 år, berättar om tystnaden kring döden i hans liv. När Arnes far dog $i$ en ålder av 50 år så pratade han och hans mor nästan inte om detta dödsfall. Under de 30 år som hans mor fanns i livet efter sin makes död berördes hans fars bortgång nästan aldrig. Det var precis som att deras delade erfarenhet av döden fanns där men den skulle aldrig komma till uttryck i ord eller handling, döden skulle enbart gömmas undan.

Det framkom dock också ett motsatt mönster i analysen av de intervjuades berättelser. Det är ett mönster som bryter mot föreställningen om gömd och glömd död under den moderna tiden. Några menade att det hade funnits en viss öppenhet kring döden trots allt. De hade pratat i vardagen kring döende och död och de berättade att deras föräldrar och andra äldre anhöriga hade varit öppna för samtal om hur de ville ha det i livets slut. Ofta hade det varit anhöriga som under en längre tid funderat på sina önskemål inför döden, och de hade även tagit god tid på sig att berätta om önskemålen för sina närstående. Intervjupersonerna hade redan fått en del hjälp med det praktiska arbetet vid föräldrarnas bortgång. Föräldrarna hade under sin levnad förberett sig genom att exempelvis ha skrivit testamente eller fyllt i något som påminner om Vita Arkivet. Flera föräldrar hade följaktligen planerat för den egna begravningen långt tidigare under sina liv: 
Frida, 72 år, berättar att det ibland kunde bli en utdragen process i det här med att planera den egna begravningen. Hennes mor, som blev 100 år, hade redan vid 90 årsåldern, eller ännu tidigare, börjat prata om sin förestående död och sina förberedelser inför den. Frida upplevde detta ältande om döden som ganska tröttsamt: "De sista åren skrev vi dödsannonser och vi bestämde blommor ... hon visste precis hur hon ville ha det och pratade med mig om det många gånger. Jag var så trött på henne ibland så ... för hon gick ju ändå i sin tomgång om du tänker". Fastän Frida upplevde det som påfrestande ibland med moderns prat om sina önskemål inför döden så är hon ändå tacksam över att modern hade väglett henne med sina sista önskningar.

Flera intervjuade uttryckte en tacksamhet - "det underlättade" och "det var bra" - över att deras föräldrar hade fattat sådana beslut och väglett dem.

Det fanns tydliga kontrasterande förhållningssätt till döden och hur man hanterade döden under denna livsfas bland deltagarna. Flera upplevde vuxenlivet som en tid då döden tonades ner i sociala sammanhang. Man sopade döden under mattan, man ville skydda varandra men även sig själv. I vissa fall var det som att de värderingar och attityder kring döden som manifesterades under barndomen inte längre fanns. För andra följde den frånvarande döden som en röd tråd genom livet. För ett fåtal hade döden emellertid varit lika närvarande under denna livsfas som tidigare under barndomen. De värderingar som hade införlivats under barndomen genom att synliggöra och prata om döden hade enligt deras utsagor kommit att prägla vuxenlivet, trots förändrade attityder till döden i samhället.

\section{Möten med döende och död de allra senaste åren}

De möten med döende och död som hade skett under de senaste åren, från 1990-talet och framåt, och som intervjupersonerna hade bevittnat, handlade i större utsträckning om deras livspartner, familjemedlemmar och vänner. Det var en tid då de så smått hade börjat gå i pension eller var pensionärer. Utifrån ett rent idéhistoriskt perspektiv, om man ser till Walters (1998) idealtyper om synen på döden, så inträffade dessa möten med döden under den postmoderna tiden med dess syn på döden. De frågor jag diskuterar i avsnittet är - Vad har de intervjuade för minnen och erfarenheter av döende och död under de senare åren? Var utspelades dessa möten med döende och död, vilka personer var inblandande och på vilka sätt hanterades döende och död? Följande mönster framkom i analysen nygamla dödsplatser - förändrade roller - ökad öppenhet. 


\section{Nygamla dödsplatser}

Ett mönster som återkom i berättelserna var att på senare år hade dödens platser åter börjat ändra karaktär. Sjukhus och andra institutioner som länge varit så typiska verkade inte förekomma lika ofta. I stället tycktes det egna hemmet åter ha blivit en plats där de själva fick vara med om närståendes döende och död. Några sade: "Det var värdigt att dö hemma med nära och kära omkring sig" och "det har vi ju återkommit till nu, den vården, att de ska få bo hemma så länge som de vill". Göte, 83 år, berättade om en döende anhörig som blev vårdad i hemmet:

Ja, han fick vård i hemmet alltså och då fick man, det är den första av alla dessa syskon till min fru, som har dött hemma alltså. Så det var ju en erfarenhet alltså och vi såg ju precis innebörden av det och vi träffade ju honom tills bara för ett par tre veckor sedan alltså.

Även Frida, 72 år, berättade om sin makes döende och död i sjukdomen Alzheimers och att vården av honom hade skett i hemmet:

Det kom att bli en utdragen sjukdoms- och döendeprocess som pågick i åtskilliga år efter det att läkaren hade fastställt diagnosen. Nästan hela sjukdomsperioden utspelades i hemmet, frånsett den allra sista månaden före makens bortgång då han hade flyttats över till ett särskilt boende. Frida konstaterar att anledningen till makens byte av boende var att hon inte längre hade orkat vårda honom i hemmet. Vistelsen i hemmet blev viktig. Första tiden i hemmet klarade han sig relativt bra själv och kunde sköta de vardagliga rutinerna, men Frida insåg ganska snart att hon skulle bli tvungen att ta ledigt från sitt arbete för att kunna hantera situationen. Hon märkte mer och mer att han inte längre kunde ta del av deras gemensamma liv och han fick också avstå från alltmer av det som tidigare i livet alltid hade tagits som självklart.

Det privata hemmet utgjorde återigen en plats där de intervjuade mötte döende och död (jfr Whitaker, 2013), men det privata hemmet hade också blivit en institutionsliknande plats som fungerade som en arbetsplats för den vårdpersonal som dagligen kom dit.

\section{Förändrade roller}

Mötena med döende och död under de senaste åren hade i större utsträckning än tidigare berört jämnårigas döende och död. Tidigare i livet hade det i de flesta fall handlat om de egna mor- och farföräldrarnas och föräldrarnas bortgång och i några enstaka fall yngre människors dödsfall. $\mathrm{Nu}$, menade några: "I den här åldern får man ju gå mycket på begravningar och höga jämna födelsedagar". Under de senaste åren hade det 
börjat glesna bland jämnåriga släktningar och vänner. Frågan som allt oftare hade ställts var: "Vem står här näst på tur?". De intervjuade hade blivit alltmer medvetna om att döden kunde vara nära förestående för de äldre närstående, men oftast kom det ändå som en chock när någon närstående dog: "Min make hade inga hjärtfel, ingenting" och "men den här [döden], var ju så annorlunda". Förr i tiden hade ju äldre människor dött, men på något vis skulle äldre närstående inte dö nu. Men det synsättet gällde inte alla intervjuade, några menade i stället att de upplevde de senaste årens alla dödsfall snarare som en ren rutinsak:

Trots att det var en älskad bror, men det var precis som ... jaa, det är nästan slut mellan oss nu, men jag var inte ledsen, särskilt, utan det var mer klart konstaterat, det är inget att göra åt nu... så jag vet att ... när han [läkaren] hade sagt en dag eller två, då var jag praktisk igen, så jag tittade mig i spegeln och sa: "Jaa, nu blir det begravning och jag måste gå och klippa mig", och det gjorde jag också. Så det gick smärtfritt...

Några nämnde att anhöriga i de yngre generationerna under de senaste åren hade hanterat och tagit ansvaret för det praktiska vid närståendes död. De intervjuade hade blivit äldre, de befann sig "senare i livet" och de verkade vara mindre aktiva när dödsfall inträffade. Deras skildringar handlade om att de nästan hade tagit ett steg tillbaka och återigen börjat inta en åskådares roll. Det kom också till uttryck på andra sätt, någon menade att det kanske kunde räcka med att man skickade blommor till en persons begravning i stället för att själv delta. Lena, 85 år, resonerande om sin roll som närstående vid två olika begravningar och hur hennes roll hade förändrats:

Det där med begravningen, alltså när det är, det kommer så mycket folk som möjligt, alltså det gav mig styrka men det var svårare andra gången än det var första. Vad det beror på det vet jag faktiskt inte. Det är svårt för att andra gången, om det nu var att jag var äldre då, för 3 år sedan, än jag var tidigare. Det är möjligt. Första gången var vi väldigt mycket folk, det var både arbetskamrater och det var vänner och släkt och jag tror att vi var mellan 40-50 personer och då var det någon som frågade vad jag hade tagit för någonting, för lugnande. Jag hade inte tagit, för jag har aldrig tagit någon gång och gjorde inte det då heller utan jag kunde hålla tal själv och tacka de som kom. Och det fungerade alldeles utmärkt. Men det måste alltså, att alla mina nära var där som gjorde det. Men det skulle jag aldrig kunnat ha gjort andra gången, det fanns inte en chans, det var svårare. Och det är möjligt att det kan vara att man var kaxigare som 66-åring.

De intervjuade menade dessutom att de döendes sätt att agera inte längre begränsades av institutionens personal. Det ligger i linje med det postmo- 
derna synsättet på döendet, det vill säga, den döendes erfarenheter, känslor och egna val sätts i centrum (Walter, 1994; Whitaker 2013). Någon sade: "Det var hans önskan och, så man satte inte in någonting, utan man [vårdpersonalen] lät honom liksom slippa, han ville inte vara med helt enkelt". Frida, 72 år, berättade om hur hennes make hade varit med och bestämt i livets slut:

Frida minns att maken nu hade kommit till vägs ände. Det blev en period tyngd av oro, ångest, existentiella tankar men också med inslag av glädje: "Han visste och jag visste, vi visste allihop att det här är inget liv, det är inte värt något, sitta här som en grönsak. Han var då på hemmet som jag kallade det för, den sista månaden, när inte jag orkade längre. Jag var där varje dag, hos honom. Men då pratade vi om det, han kunde inte prata så bra men vi kände ju varandra så väl, så jag visste ju ändå. Och jag vet och han vet, visste att jag ville att han skulle dö helt enkelt, för det var inte värdigt. Och där satt han, hade suttit i 5 år och jag fattar fortfarande inte hur han kunde förstå det men jag vet att han gjorde det. Och han bestämde sig alltså, så han tog livet av sig genom att inte äta och dricka. Med doktorns goda minne och sköterskorna och allihop visste. De försökte ju få honom att öppna munnen men, så hans död, för både mig och barnen, är en otrolig beundran, för hans mod, att ta det här steget när han var så sjuk. / . . / Och alla visste vi att så här ville han ha det, och kunde respektera honom och det blev helt odramatiskt och han visste att vi var där hos honom i rummet, allihop. Och efteråt så sade läkaren: - Det var en kärleksgärning till er! och det kan jag ju känna, det var det".

En deltagare konstaterade hur förvånad han hade blivit när han bevittnat den originella ceremonin vid en yngre kvinnas begravning: "Hon visste precis hur begravningen skulle vara, vilken musik och vilken ordning det skulle vara /.../ hon måste alltså ha vetat det där, att hon skulle dö /.../ Hon hade regisserat hela sin begravning alltså”.

Flera ansåg att de hade börjat ta ett kliv tillbaka och inte var lika engagerade längre i mötena med närståendes döende och död - och att den döende och "den döde" hade fått en mer aktiv roll nu än vad tidigare döende individer hade fått.

\section{Ökad öppenhet}

Några intervjuade ansåg att det under de senaste decennierna hade skett en attitydförändring till döden som innebar en tilltagande öppenhet i dess hanterande. De påpekade att det först och främst hade gällt media och då åsyftades nekrologernas och dödsannonsernas utformning. Åkesson menar att: "För inte så länge sedan var inställningen till annonsernas symboler också mycket konservativa. Så är det inte i dag" (Åkesson, 1997, s. 87). 
Några förde ett resonemang om det nu för tiden varierande urvalet av symboler på dödsannonserna:

Nej, jag tycker nästan det är lite väl profant. Det kan ju inte vara livets bästa värde att vara AIK:are, eller så. Inget fel i det alls men ändå, men jag tycker ändå, då har jag mer förståelse för att man kan vara seglare och hängiven sådan då, för då är det ju en naturupplevelse på något sätt, mitt $i$, allt livs ursprung är vatten och så här, man får ändå lite djupare insikter, man blir ju lite förvånad ibland när man ser vissa symboler numera på dödsannonserna. Men det är klart, det är väl bra i och för sig, att det är friare också. Tidigare var det bara kors och det var väl lite hycklerier runt det förstås.

Jadå, hundar och katter och allt möjligt [som symboler på dödsannonserna], jodå, som har varit deras bästa vän i livet och det förstår jag. Jag skulle gärna sätta dit hela Kolmården om det går.

De intervjuade menade att man pratade om döden på ett alltmer öppet sätt. Anhöriga hade också börjat planera och förbereda sig inför sina begravningar på ett mer genomtänkt vis än tidigare, och de genomfördes inte längre bara på traditionsenliga vis. Tidsandan, menade de, hade blivit mer tillåtande och att man kunde börja laborera mera med döden (jfr Howarth, 2007; Walter, 1994). Attitydförändring hade även gällt begravningsarrangemanget där nya traditioner skapades, vilket några uppfattade som befriande:

Celia, 86 år, berättar om sin svåger och hans begravning som hölls i ett litet kapell intill Karolinska sjukhuset. Det fanns möjlighet att ha sin förrättning i detta kapell vare sig man var troende eller inte. Hon nämner att det var en vacker begravning: "Den var väldig ljus /.../ vi hade dikter av Bo Zetterlind och det var jazzskivor, han tyckte om jazzmusik min svåger, det var sådana skivor som spelades. Och sedan fick man inte lägga några blommar på kistan, för att det som den var klädd med var väldigt dyrbart och fint och fick inte förstöras på något vis, om de lägger ned då... ja, det var faktiskt en upplevelse, en sådan begravning. Den var väldigt ljus /.../ Den var verkligen fin den begravningen...

De anhöriga hade också blivit mer benägna att faktiskt tala om hur de ville ha det i livets slut - antingen muntligt eller nedskrivet så att allt kunde "följas till punkt och pricka": 
Elsa, 71 år, kommer ihåg att hennes moster hade planerat sin begravning in i minsta detalj. Vid 88 årsålder höll Elsas moster dock fortfarande på att överväga vilka sånger som skulle sjungas på hennes begravning. Elsa minns en Allhelgonhelg när hon tillsammans med maken och mostern hade besökt kyrkan nere i byn och tänt ljus på de anhörigas gravar. De satt i kyrkan och mostern hade sagt: "Du Elsa, den där biten, tycker du jag ska ha den på min begravning, tycker du om den? Den var himla lång, ja men du, jag tar den också". "Hur många har du tagit då", sa Elsa. De satt där och diskuterade och mostern visste ju precis hur hon ville ha det. Dagen efter ringer hennes moster: "Nej men Elsa, den där jag sa till dig igår, den struntar vi i nu", hade hon sagt, "och så tar vi den här i stället".

Några påtalade också att inom vården och omsorgen hade det börjat ske en attitydförändring: "De talar öppet om sådant [döden] i dag" och döden skulle också visas upp på ett annat vis än förr: "Alla andra gick dit till bårhuset och tittade på honom, men jag ville inte se honom död. Jag ville ha honom levande. - Ni får gå och glo så mycket ni vill på honom, men jag vill inte göra det!". Det handlade också om att de som anhöriga fick vara med och ta viktiga beslut angående någons döendeprocess. Isak, 75 år, berättade: "Hon låg ju på intensiven min fru då, så att jag vårdade inte fysiskt. Jag var väl där varje dag och jag såg utvecklingen och det dramatiska, traumatiska av att stänga av respiratorn för att det går inte längre och sådant får man besluta, man får fatta i samråd med döttrarna”. Frida, 72 år, berättade om sitt möte med en psykolog och hur värdefull kontakten hade varit i samband med ett dödsfall i familjen:

Jag fick väldigt bra hjälp av henne på det viset att hon inte sade så mycket, de gör väl inte det, om de är kloka terapeuterna, utan det var jag som pratade. /.../ Men det var värdefullt, oerhört värdefullt, annars så vet man ju inte, jag kan ju inte svara på hur det skulle gått annars men det är klart att det underlättade, det gjorde det helt klart, visst.

Det framkom också ett motsatt mönster. Inte alla intervjuade ansåg att attityden till döden hade börjat förändras under denna tidsperiod. Någon menade: "Begravningsentreprenörer [tar] hand om liket och man ser det inte om man inte vill det. Så att det är klart att på det sättet är ju döden mer anonym då om man säger så". Döden var fortfarande ett ämne som skulle hållas på avstånd så länge det var möjligt. Några nämnde just att funderingarna på den egna döden inte sällan hade börjat aktualiseras när vänner och anhöriga hade gått bort, vilket hade fått dem att börja planera inför döden genom att bland annat fylla i det Vita Arkivet. Allt för att på så sätt underlätta för de efterlevande. När de sedan hade fört detta på tal med livspartnern, barn och andra anhöriga hade det emellertid mötts med 
motstånd. De hade inte velat, de hade skjutit det ifrån sig och hade ansett att döden hörde framtiden till. Det hade, enligt de intervjuade, alltså inte gått att föra en diskussion om döden om eventuella önskemål inför döden:

Det enda min make ville och gjorde, beställde, begravningsplats i byn. /.../ Och där ville ju min make ha sin begravningsplats, det är allt som vi har talat om, han ville inte beröra, jag frågade så många gånger hur han hade tänkt och hur vi skulle ha det, men, nej, det ville han inte vara med om och prata om. Men jag var med i alla fall, vi var på kyrkogården när vi träffade kyrkogårdsvaktmästaren där ute $i$, det är ett stort antal år sedan och frågade då om det fanns någon plats ledig bredvid hans föräldrar då, och det gjorde det. Så den blev ju reserverad, jag vet inte ... ja, jag sade: - Kan man reservera? Ja, det kunde man göra, jag tyckte det lät så konstigt, men den var utsedd ... av honom själv. Och det skulle vara jordbegravning, så mycket visste jag.

Hanteringen av döden under den här delen av de intervjuades liv uppvisade olika mönster. Å ena sidan pekades på en attitydförändring i samhället kring döden - en mera öppen attityd med utrymme för personliga synpunkter, önskemål och val - ett möte mellan tradition och nyskapande. Å andra sidan påpekades också att tystnaden kring döden fortfarande var påtaglig.

\section{Sammanfattning}

I detta kapitel har jag diskuterat forskningsfrågan: Hur beskriver äldre människor sina tidigare erfarenheter av döende och död? Det jag har fokuserat är relationen mellan åldersrelaterade roller, död och historisk kontext.

Var ägde mötena med döende och död rum? Mötena med döende och död utspelade sig på, och var förknippade med, olika platser under livet. Det privata hemmet var inte sällan den plats där de intervjuade hade mött döende och död som barn och unga. Hemmet hade då blivit en plats där de kollektiva traditionerna och ritualerna kring döende och död hade ägt rum. Senare under livet, under tidsperioden från 1950-talet fram till och med 1980-talet, ändrade dödens platser karaktär. Hemmet som dödens plats hade nästan försvunnit. I stället hade det blivit på institutioner sjukhus och äldreboenden - som anhörigas döende och död hade utspelats. Där hade döden blivit undangömd. När de intervjuade sedan skildrade sina allra senaste möten med döende och död handlade det inte längre bara om institutioner. Det privata hemmet hade återigen blivit en plats där döende och död ägde rum, samtidigt som hemmet hade blivit en institution som fungerade som en arbetsplats för hemsjukvård och hemtjänst. 
Vilka personer var inblandade i mötena med döende och död? De intervjuades livsberättelser visade att med ålder skiftade också förpliktelserna i samband med döende och död. Olika åldersrelaterade roller tilldelades beroende på var i livsloppet man befann sig. De här åldersrelaterade rollerna förknippades ofta med förväntningar, normer och regler, som bland annat kunde relateras till ansvarsfrågan. Döendet och döden var ofta skrämmande, spännande och obegriplig för de intervjuade när de som barn och unga mötte döden. Döden sysselsatte ett kollektiv av närstående som tillsammans genomförde de gamla och välbekanta dödsritualerna, och där de intervjuade följde denna sociala händelse på håll. De närstående hade således haft det delade och gemensamma ansvaret. Senare i intervjupersonernas liv var mötena med döende och död inte längre en social händelse som samlade ett kollektiv av närstående, det hade snarare kommit att bli en privat angelägenhet. De hade nu en annan roll än tidigare i livet. Ansvarsfrågan hade förändrats och var inte längre fördelat på de närstående. De intervjuade stod i stället själva med ansvaret, men nu tillsammans med experterna. När de intervjuade sedan berättade om de allra senaste årens möten med döende och död hade rollfördelning återigen förändrats. Flera menade att de hade tagit ett kliv tillbaka och inte var lika aktiva vid närståendes döende och död - de hade alla kommit att inta en förväntad åldersrelaterad roll. Dessutom ansåg flera av de intervjuade att närstående döende själva hade fătt en mer aktiv roll nu än vad döende personer tidigare hade haft. Det gavs utrymme för personliga önskemål och val, där man eftersträvade det autentiska och äkta. Den utvecklingen kan ses som ett uttryck för det som Åkesson kallar "en intimisering av döden" (Åkesson, 1997, s. 17f, 182f).

På vilka sätt hanterade man döden? A ena sidan fick man som barn bekanta sig med döden, det fanns en viss öppenhet kring döden, den skulle ingå i den vardagliga erfarenhetsvärlden - den sociala tillhörigheten skulle skapa en slags trygghet. Å andra sidan, för vissa intervjuade, hade döden inte alls varit präglad av någon naturlig öppenhet. Döden skulle man skyddas ifrån, den skulle inte synliggöras och inte heller få ingå i deras erfarenhetsvärld under barndomen. Senare, då de intervjuade befann sig mitt i livet, tycktes den tidigare öppna hållningen till döden förändras. Flera upplevde denna fas av livet som en tid då döden tonades ner i sociala sammanhang, man ville skydda varandra men även sig själv döden hade blivit främmande. Ett fåtal framhöll dock att döden hade varit lika närvarande under denna livsfas som tidigare under barndomen. När de berättade om sina allra senaste möten med döende och död pekade flera på en attitydförändring i samhället kring döden. Det handlade om individualitet och pluralism, det vill säga, en mera öppen attityd och ett utrymme för personliga synpunkter, önskemål och val, ett möte mellan 
tradition och nyskapande. Några intervjupersoner påpekade däremot att tystnaden kring döden fortfarande var påtaglig - ett arv från den moderna synen på döden.

Detta kapitel har visat att de intervjuades erfarenheter och minnen av döende och död är mångfacetterade och motsägelsefulla, och färgade av såväl traditionella, moderna som postmoderna förhållningssätt till döden. Nästa kapitel handlar om intervjupersonernas funderingar på döende och död i dag, här och nu. 


\title{
KAPITEL 5
}

\section{Tankar i vardagen på döende och död}

\begin{abstract}
Vi sitter vid köksbordet i Astas, 77 år, stuga ute på landsbygden och samtalar om framtiden och om döden. Utanför fönstret skiner solen på de alltmer rödgulnande bladen, hösten är här. Hon berättar att detta har varit hennes hem i snart 35 år och hon upplever det som en ganska så lång tid av sitt liv, men hon säger samtidigt att tiden och åren har gått snabbt. När samtalet går över på temat döden berättar hon att hennes tankar på döden återkommer oftare numera än förr i tiden och hon förmodar att det kanske har med åldrandet att göra, dessutom nämner hon att de här tankarna vanligtvis dyker upp då hon känner sig ensam och tycker att livet är trist. Senare under samtalet faller hennes blick på köksgolvet och hon berättar att hennes make dog just här i köket år 2000, han ramlade på köksgolvet och dog omedelbart av en hjärnblödning. Minnena från makens bortgång gör sig ibland påminda och det får henne att då och då börja fundera över den egna döden. Hon nämner att hon hoppas att hennes död blir lika ögonblicklig som makens och att någon närstående kommer att finnas vid hennes sida, precis som då för tio år sedan när maken dog.
\end{abstract}

Detta kapitel handlar om intervjupersonernas tankar och funderingar på döende och död i dag, här och nu. På vilka sätt knyter då kapitlet an till det föregående, som handlade om deras erfarenheter av döden? De förflutna mötena med döende och död fanns kvar som lämningar, erfarenheter och minnen hos de intervjuade. Genom livet i olika sociala miljöer hade, som framgick i kapitel 4, mötena med döden varit med och format deras sätt att agera och förhålla sig till döden. Genom erfarenheter och minnen - och förväntningar inför framtiden - kunde de intervjuade "låta andra skeden än det närvarande påverka [dem och ge deras] samtid dess kvalitet" (Lundmark, 1989, s. 157).

Asta umgicks då och då, som framkom ovan, med funderingar kring döende och död. Det var vardagliga platser, händelser, relationer och föremål i hennes närhet som väckte sådana tankar, som vanligtvis handlade om närståendes döende och död. Det var heller inte ovanligt att tankarna rörde hennes egen död, främmande människors död eller döden som fenomen. Det fenomen som Asta gav uttryck för - att vardagslivet ibland upptogs av funderingar på döden - Var det vanligt förekommande bland 
deltagarna i studien?

Det här kapitlet fokuserar forskningsfrågorna: Hur ser äldre människor på det egna döendet och död? Vilka erfarenheter har äldre människor av möten med döende och död i det vardagliga livet?

Kapitlet har en tematisk disposition. I det inledande avsnittet diskuterar jag om de intervjuade funderade på döende och död i vardagen. Därefter följer ett antal avsnitt med fokus på var, när, hur och i vilka sammanhang tankar om döende och död uppstod, samt vad dessa funderingar handlade om. Analysen synliggjorde ett antal teman som går att sammanfatta under följande rubriker - tidpunkt för tankar om döden - rum som väcker tankar om döende och död - förluster - att hantera funderingar på döende och död.

\section{Tidpunkt för tankar om döden}

Hur var det då för de intervjuade? På vilket sätt funderade de och förhöll sig till insikten om att vi alla en gång i framtiden ska dö? Varierande bilder förmedlades i de 27 berättelserna. Någon intervjuad menade: "Det är ju ofrånkomligt att man tänker, men å andra sidan varför ska jag tänka, jag vet att det kommer att ske, okej, vi tar det när det kommer!". För några var det självklart att tänka på döende och död, om inte dagligen så ganska ofta. Somliga berättade att de emellanåt hade sådana funderingar, medan andra nästan aldrig hade det. Ett par av de intervjuade nämnde dessutom att det var jag som hade fått dem att börja fundera och gjort dem påminda om sådant som berörde döende och död. Isak, 75 år, sade: "Så här mycket tankar på döden har jag inte haft förrän du sitter här och frågar!" Att det fanns både komplexa och motsägelsefulla föreställningar och förhållningssätt i deras syn på det egna döendet och döden märktes inte minst i de enskilda intervjuerna. Det var ämnen, frågor, tankar och idéer, som gav upphov till en känsla av ofrånkomlighet, obehag och rädsla hos vissa intervjuade. Inte heller var det alltid så att funderingarna på döden var rationella. Bertil, 84 år, svarade när han fick frågan om han tänkte på döende och dö nuförtiden: "Nej, nej, inte ett dugg!" Senare under intervjun, när vi kom in på frågor om "efter döden", blev han påmind om att han ofta lånade böcker på biblioteket som handlade om döden och existentiella frågor. Den fråga jag diskuterar i det följande avsnittet är: Funderade de intervjuade överhuvudtaget på döende och död i vardagen? Frågan ledde till två diametralt olika mönster - hög tid att påminnas om döden - döden bör hållas borta. 


\section{Hög tid att påminnas om döden}

I de intervjuades berättelser fanns det beröringspunkter mellan det egna åldrandet och tankar på döden. Flera lyfte fram sin ungefärliga ålder som en slags referenspunkt, vilken de förhöll sig till då de resonerade kring huruvida de tänkte på döden eller inte:

Jens, 72 år: "Jaha, nu är du 72 år, undrar hur många år du har kvar", det är klart att sådana tankar infinner ju sig.

Malte, 80 år: Men det är väl i stort sett döden man väntar på nu när man är 80 .

Ett inte ovanligt påstående var att tankarna på döende och död infann sig oftare nu för tiden än förr då de var yngre. Tankarna kom automatiskt när man började bli äldre och gammal, och på något vis ingick det i livsfasen att fundera på döden, menade några intervjuade:

Jens, 72 år: Jo, det är klart, det kommer ju närmre. Det är ofrånkomligt, så är det ju med stigande ålder. Det är ju ofrånkomligt så visst har de det. Det är klart att det dyker ju upp i tankarna mer frekvent nu än vad det gjorde i yngre år. Det är alldeles självklart, så är det ju.

Jenny, 85 år, menade att dessa tankar var oundvikliga och dessutom kunde de vara otäcka:

Och jag vet ju, ibland kan jag tycka att det är lite läskigt att man är så gammal och att det bara finns en bit utförsbacke kvar. Hur lång den backen är vet man ju inte men den finns där. Det är inte en uppförsbacke och livets glada. Ja, det tänker jag på ibland.

Andemeningen i deras resonemang - det var oundvikligt att de egna tankarna då och då upptogs av döden då man i realiteten inte hade så många år kvar att leva. Carl, 71 år, sade: "Man är så realistisk och det måste man ju vara, så att man inser att det blir kortare och kortare det man har kvar. Jag menar, det [ämnet döden] poppar ju upp i huvudet då och då!" Det handlade om funderingar kring både den egna och andras döende och död. Döden hade på sätt och vis kommit för att stanna - "döden finns, ja det är inte någonting som jag har glömt bort eller stoppat undan". Det gick inte längre, menade några, att ignorera döden på det sätt de hade kunnat göra tidigare under livet - undvika tankar på döden för att den låg för långt fram i tiden. Någon sade: "Jag trodde aldrig att jag skulle dö heller [när hon var ung] men nu börjar jag förstå att det ska också jag 
göra!" Jag tolkar det som att de intervjuade ansåg den uppnådda (höga) åldern som en naturlig tidpunkt i livet då det förväntades vara "normalt" att ha tankar på döden. De tycktes hysa en insikt om "memento mori", det vill säga, "kom ihåg att du ska dö". Memento mori kan fungera som en levnadsregel, vilken påminner oss människor om livets förgänglighet och som ger andra perspektiv på livet, menar vissa forskare (Silfving, 2007, s. 11ff; Ågren Bolmsjö, 2006, s. 65ff). Genom att begrunda det faktum att man är dödlig "höjs den dagliga livskvaliteten" (Kallenberg, 2007, s. 201ff). Medvetenheten om döden "kan få en människa att mogna och utvecklas" (Kübler-Ross, 1988, s. 143), och det anses ibland som betydelsefullt att "bli vän med livet och döden" (Frostegren, 2000, s. 17ff). Flera forskare menar också att döden är "en förutsättning för att livet ska få en mening" (Ågren Bolmsjö, 2006, s. 65).

De här förhållningssätten till döden ligger i linje med det som några av mina intervjupersoner förmedlade i sina utsagor, det vill säga, döden hade blivit en lika väsentlig ingrediens av den kvarvarande tiden som livet självt. Att låta tankarna på döden då och då få influera det vardagliga tänkandet tycktes till och med ha en försonande inverkan på intervjupersonernas föreställningar om den senare delen av livet. Några som, i kapitel 4, menade att det livet igenom hade funnits en öppenhet kring döden, framhöll: "För att finna meningen med livet behövs döden", "döden är ju en naturlig följd av livet" och "livets mål är ju döden egentligen". För dem handlade det på sätt och vis om att bli gammal och om att våga dö. Någon menade: "Det kanske ligger däri att jag, som jag sade förut, så ska jag teoretiskt sett snart dö själv, så jag måste ju vänja mig så att säga. Men det är inga svårigheter!"

För att återknyta till ett av Giele och Elders (1998) nyckelbegrepp tid och timing (se även Neugarten, 1979; Närvänen, 1994), så handlar detta mönstret om en tidsmässig anpassning till det "normala" livsloppet, det vill säga tankar på döden förväntades vara närvarande vid denna tidpunkt i livet. Funderingarna var så att säga "on time" vare sig man var 70 eller 91 år. Dessutom fanns det, menade flera, en poäng med att påminnas om "ens dödlighet" och att väva in döden i den vardagliga erfarenhetsvärlden.

\section{Döden bör hållas borta}

I kontrast till resonemangen ovan använde några i stället det egna åldrandet som ett argument för varför de nästan inte ägnade döende och död någon tanke alls. På frågan om de funderade på döende och död nuförtiden, svarade de: "Nej, jag känner mig ung så det gör jag inte /.../ jag ska fortsätta att leva och leva och leva", "döden kommer när den kommer, det vet man om nu" och "jag har inte tid att tänka på döden, livet väntar!" Bertil, 
84 år sade: "Nej, nej, inte ett dugg. Jag tänker mer på, jag är engagerad i museiföreningen här nere [och] jag står långt från döden...!" Bertil var annars en av dem som gav uttryck för att det alltid hade funnits en öppenhet kring döden genom åren, och att han hade kunnat prata om döden med närstående (se kapitel 4). Med andra ord, att ha uppnått en relativ hög ålder innebar alltså inte per automatik att de intervjuade började fundera på döden, vare sig den egna, andras eller döden som fenomen. Inte heller bedömde de det som "normalt" att i denna livsfas förväntas ha funderingar på döden. Varför skulle det ödslas tid och kraft på sådana tankar? Döendet och döden tycktes inte ingå i intervjupersonernas vardagliga funderingar. Snarare prioriterade de tankarna på livet. Någon menade: "Det är inte så himla kul att gå och tänka på döden, jag vill ju hellre njuta av päronträdet som blommar!" Maja, 78 år, men även Gerd, 70 år, som hade upplevt en uppväxt där döden tystades ner, var båda inne på samma linje - att det var livet som var viktigt:

Jag har ju livet utanför här, tänker på livet ... varför skulle jag tänka på döden då så ofta?

Döden ligger en bra bit framåt i tiden, så därför tänker inte jag så mycket på det.

De här intervjupersonerna ifrågasatte också om de verkligen borde ägna den återstående tiden av livet åt tankar som handlade om döende och död. "Varför oroa sig i onödan", "är det sunt att tänka på döden" och "det skulle jag inte vilja göra, gå och tänka på den [döden], nej", var typiska utsagor. Isak, 75 år, och Kurt, 78 år, ifrågasatte också varför de skulle fundera på döden:

... för mig tror jag att livet är lite lättare att leva än om man ständigt går och tänker, när dör jag, hur vill jag dö och, jag kan inte styra det så jävla mycket utan ... kan säga så här att döden upplever jag inte som en aktualitet, inte omedelbart aktuellt.

Tycker du att det är mänskligt att gå och tänka på döden? /.../ Jag tror egentligen att det är något emot den mänskliga naturen att hålla på och fixera sig vid döendet.

På liknande vis som naturvetaren och romanförfattaren Canetti menar att funderingar på döden berövar livet dess hela mening (Canetti, 1996; Kallenberg, 2007, s. 203), så ansågs döden av några intervjuade som så omänsklig att man överhuvudtaget inte borde tänka på den. Det fanns alltså inget fruktbart i att se livet och döden sammanflätade, menade de - 
att medvetandegöra döden hjälpte knappast till att ge någon mening åt den kvarvarande tiden.

De såg heller inte någon poäng med att tänka på döden så länge de var friska. Det kunde de i stället göra när de hade blivit äldre och gamla, skröpliga, döende eller drabbade av en dödlig sjukdom. Några menade: "Jag är frisk och därför tänker jag inte på döden" och "det är ju bara naturligt att tänka på döden när man är döende". De framhöll att tack vare sin goda hälsa och att de alltid varit friska så fanns det ingen anledning att börja fundera på detta. Fokus borde i stället ligga på livet och att tänka positivt. " - Lev i stället! brukar jag säga, skratta och var glad, problem finns det alltid, det blir det alltid med något" och "jag tänker på att köra hårt i minst 15 år till", sade Fred, 77 år, skrattandes.

De här intervjuade bedömde inte att livsfasen de befann sig i var "on time" att ha tankar på döden vare sig vid 70, 80 eller 91 år. Dessutom ansåg de att det för en fullt frisk människa inte fanns tid över för sådana tankar och att det inte var meningsfullt att fundera på döden i vardagen (jfr Howarth, 1998; Lloyd-Williams et al., 2007, s. 65). I några fall kanske det också handlade om en stark inre försvarsmekanism - att förtränga tankarna på döden. Hos andra kanske fanns en inre resurs, i linje med den Cicirelli (2006, s. 357) nämner och som innebar att man både kognitivt och känslomässigt bearbetade döden och därför kunde "avdramatisera och tona ner den". Intressanta i sammanhanget är att det inte förklarar - varför de som inte funderar på döden frivilligt deltar i en studie som nästan uteslutande handlar om döden (jfr Cicirelli, 2006, s. 357).

\section{Rum som väcker tankar om döende och död}

I analysen framkom att olika platser kunde väcka tankar om döende och död hos de intervjupersoner som uppgav att de då och då eller nästan dagligen funderade på döden. Även de som sade sig aldrig fundera på döden blev ibland påmind om den i olika situationer i vardagen. Tankarna kunde uppstå av flera anledningar, under olika omständigheter och i helt olika situationer, vilket Jens, 72 år, tydligt beskrev:

Ja du, det kan vara precis när som helst. Det ser jag egentligen inget mönster i. Det kan ju vara precis när som helst. När man besöker sina barnbarn eller man är i kolonin, man ser växterna spira där, så det kanske är sista gången jag ser blommorna komma upp ur jorden där och så här på våren. Ja, så att det kan ju vara precis när som helst, absolut, så det är svårt att hitta något mönster där.

Det behövde inte heller alltid vara yttre händelser eller platser som väckte tankar kring döden. De kunde lika gärna uppstå ur känslor, eller dyka 
upp utan någon särskild anledning. En av de intervjuade sade: "Ibland är man ju så barnslig, då när man ligger och tänker lite grann, över det vanliga, då kan man ju dra sig till minnes kanske - men vad vackert det var [en begravning], det kanske jag skulle tänka mig men det försvinner lika fort, du vet, det är bara tankar som kommer upp." Det gick således att härleda deras tankar ifrån ett helt spektrum av vardagliga händelser. Alltifrån platser som var starkt förknippade med döende och död till platser vars sammankoppling med döden inte alls var lika självklar.

De frågor jag diskuterar i följande avsnitt är: Var och i vilka vardagliga sammanhang och situationer uppstod tankar på döende och död, och vad kunde dessa funderingar handla om? I analysen har jag tagit hjälp av Gieryns (2000) definition av begreppet plats utifrån de tre kriterierna platsens geografiska läge, platsens "fysiska utformning" och platsens symboliska innebörd. Det handlar om var tankar på döden väcktes, vad det var på platsen som framkallade funderingar och vad platsen gavs för symbolisk innebörd. Här var det framförallt fem platser/rum som framkom i analysen - kyrkogården - sjukhus och äldreboende - hemmet - naturen det mediala rummet.

\section{Kyrkogården}

En inte helt oväntad plats där funderingar på döden framkallades var i kyrkor och på kyrkogårdar. Åkesson menar att kyrkor och kyrkogårdar är något annat än enbart neutrala och geografiskt avgränsade rum: "Att gå in i dessa rum innebär att korsa gränser, att rågången mellan liv och död blir konkret och tydlig genom sin rumsliga representation" (Åkesson, 1997, s. 10). Kyrkogården utgör också ett rituellt rum med öppen och offentlig karaktär, där man mediterar och blir påmind om de döda och om döden själva grundtanken med kyrkogården bygger på dess visualitet. Den utgör en plats för både döda och levande (Åkesson, 1997, s. 128, 145). De flesta intervjuade berättade att de besökte kyrkogården då och då och att avsikten med besöken oftast var att sätta blommor, tända ljus och se till att "det alltid är fint på gravarna". Någon sade: "Min mamma hon var väldigt bunden vid den här graven och besökte den ofta och det är lite för att hedra hennes minne som jag fortsätter!" Genom att besöka graven och pynta den skapades minnen kring de döda anhöriga. Platsen fylldes med minnen, mening och symboliker. Några sade dock att besöken på kyrkogården inte skedde mer än pliktskyldigast för att pynta någon anhörigs grav och att det hände ytterst sällan: "Då kan det vara skönt att säga - javisst fan har jag varit där. Det var lika visset nu som då". I de fallen handlade det snarare om att de intervjuade varken ville, kunde eller hade något behov av att besöka kyrkogården. Anledningen kunde vara tidsbrist, brist på intresse eller som någon valde att uttrycka sig: "av lathet". 
Det kunde också bero på att gravplatsen med tiden hade gått från att ha varit meningsbärande till att nästan bli till en börda eller att platsen väckte alltför starka och obehagliga minnen och att besök därför undveks.

Det var inte heller ovanligt att de ibland vandrade ensamma fram längs gångarna på ortens kyrkogård för att titta på gravstenarna, minnas de bortgångna och tider som flytt. Arne, 86 år, som nämnde att han nästan aldrig funderade på döden, och att döden alltid hade varit frånvarande, konstaterade att han däremot då och då besökte kyrkogården: "Jag, känner igen en förfärlig massa folk alltså /.../. Det är hemskt egentligen!" Flera upplevde också en inre ro vid besök på en kyrkogård och det fanns alltid tid för eftertanke. Erik, 70 år, sade: "Det är vackert på en kyrkogård egentligen. Jädrigt fint, åtminstone här nere, många kyrkogårdar är vackra, rogivande på något konstigt sätt." Att vandra mellan gravarna gav inte sällan upphov till existentiella reflexioner kring liv och död - "Liten sådan där sentimental känsla då att det är en kontakt [med de döda föräldrarna], på något sätt, konstigt nog". Jenny, 85 år, berättade om sina funderingar:

Ja, och dit går jag, men, jag går därför att jag tycker det ska vara lite fint hos dem och att det är en stund med dem. Man vet ju aldrig, allt som skrivs nu om att de är närvarande. Jag vet inte om de sitter där och där. Det vet man ju inte.

Det fanns även exempel i de intervjuades berättelser att besök på kyrkogården kunde få dem att ändra uppfattning om kyrkogård, begravningssätt, etcetera. Göte, 83 år, berättade att under de senaste åren hade han varit på "två eller tre begravningar varje år" och de här begravningarna hade "väl kanske gjort också att man kommer närmare det [döden] och ser innebörden av det alltså". Han berättade följande lilla episod, som utspelades vid en av de senare begravningarna, vilken hade fått honom att se döden ur ett annat perspektiv:

En av släktingarna som var närmast oss, min fru och mig alltså, begravdes då och det var vinter och kistan fördes då på slippriga vägar fram till graven, den uppgrävda graven alltså. Och här står man, jag höll på att ramla ner i graven och jag kände sådan där fasa för det här svarta hålet alltså. Det är möjligt att det kan vara ett slags skräck inför döden alltså, det kan vara det alltså. För sedan gick vi då upp till kyrkan som ligger på en höjd med en otrolig utsikt över hela bygden och med sjön nedanför som i sin tur har förbindelse med Mälaren. Där ligger minneslunden alltså, och där ska ens aska strös ut alltså och, det där har för min del gjort mig helt lugn inför allting som hör ihop med livets slut så att säga. 
Först var Göte alltså tveksam till begravningssättet - jordbegravning eller kremering - men efter den här incidenten stod det dock klart att han skulle välja kremering. Magnússon menar: "Att delta i en anhörigs begravning är exempelvis som en generalrepetition inför ens egen" (Magnússon, 2004, s. 73). På något vis verkade detta ha varit en generalrepetition inför Götes egen begravning då kyrkogårdens symboliska och rituella värld sammanbands med hans syn på verkligheten, livet och döden (jfr Åkesson, 1997, s. 148).

Kyrkogården var alltså den offentliga plats där de intervjuades privata ritualer kring minnena av de döda pågick, men också den plats som kunde binda samman tankegångarna kring tidigare generationers död med den egna kommande döden och de existentiella frågorna om döden.

\section{Sjukhus och äldreboende}

De intervjuades berättelser handlade också om möten med döden på andra platser som vanligtvis anses starkt förknippade med döende och död, som exempelvis sjukhus och äldreboenden. Om kyrkogården utgjorde den offentliga plats där minnen av tidigare generationer återskapades så innebar de offentliga institutionerna en direkt och konkret kontakt med döende och döda närstående. Där skådades döden så att säga i vitögat. Institutionerna var miljöer som några bara emellanåt besökte medan andra besökte dem mer frekvent. För de intervjuade var dessa möten med döende anhöriga såväl en privat händelse som en social händelse. Det var möten som väckte tankar om den egna döden men också funderingar om sociala relationer som snart skulle upphöra. Flera menade att glädje, förhoppningar, planer och måsten föll bort i dödens närhet. En intervjuad nämnde: "När man lever mitt uppe i alltihop, i glädjen, så har man inte alls de tankarna omkring sig!" När sedan sådana möten med döende och döda närstående inträffade så handlade funderingarna nästan enbart om detta. Det fanns också en rädsla för att själv hamna på något sjukhem, äldreboende eller sjukhus och förvandlas från självständig individ med "en personlighet och med erfarenheter" till "hjälplöst kolli". Det var just i dessa möten med döende släktingar och vänner som oron inför den egna döden framförallt väcktes (jfr Giordano, 2000, s. x). Asta, 77 år, beskrev hur hon tänkte efter att ha besökt en närstående på ett sjukhem:

Jag tyckte det var förskräckligt att komma där och se alla gamla som inte kan knappt äta själva och sådär, vet du. Han hade cancer i hela kroppen, i två år så låg han därute och sista månaden var det hemskt, usch så sjuk han var. /.../ Då brukar jag tänka, ska jag ligga så där likadant, usch. Nej, det är det enda, men jag hoppas att jag slipper... 
För flera intervjupersoner var sinnebilden för äldreboenden - beroende, ett utdraget döende och lidande. Det är en bild som påminner mycket om sinnebilden för den moderna sjukhusdöden: "den kala, sterila sjukhussalen där den döende ligger ensam och övergiven och övervakad av en teknisk apparatur" (Magnússon, 2004, s. 73). Whitaker (2004) beskriver inte sjukhemmet som vilket neutralt och geografiskt avgränsat rum som helst, utan som livets sista boning där gränsen mellan liv och död är tydlig genom dess rumsliga representation. Sjukhemmet kan både symbolisera institutionen och hemmet där rutiner blandas med känslor, samtidigt som det är en plats som kan upplevas både skrämmande och trygg för boende och anhöriga. Sjukhemmet beskrivs också som den "lilla världen" eller livsrummet som sakteliga krymper alltmer och till sist kanske bara innefattar sängen. Denna "lilla värld" var en plats där de intervjuade inte ville möta sin kommande död. Liksom i Whitakers studie så tyckte de intervjuade emellertid att det inte var mötet med döden på dessa institutioner i sig som var mest fasansfullt utan hur de äldre tynade bort, både kroppsligt och mentalt (Whitaker, 2004).

Äldreboenden och sjukhus utgjorde de platser där döendet och döden konkretiserades. Dessa möten med döende och död på institutioner utgjorde både en privat och en social händelse för de intervjuade, där tankar på det egna döendet och döden medvetandegjordes och där andras döende blev som allra mest påtagliga. Det handlade också om att platsens inramning och representation gav upphov till en aha-upplevelse - att så här var det kanske att dö. Deras besök på institutionerna återförde med andra ord döden till den vardagliga erfarenhetsvärlden.

\section{Hemmet}

Det egna hemmet och dess rum kanske inte väcker några särskilda associationer till döende och död för en utomstående men var inte sällan den plats där intervjupersonerna kunde börja fundera kring den egna och närståendes döende och död.

En intervjuperson berättade exempelvis att köksgolvet utgjorde då och då en påminnelse om att döden kunde vara obeveklig: "Min man dog år 2000, han ramlade här på golvet och dog direkt". Några nämnde också faror eller tillbud som nyligen hade inträffat $i$ hemmet och som fick dem att börja tänka på hur skört livet kunde vara. Det kunde handla om hala badrumsgolv, branta trappor eller förrädiska mattor som på ett eller annat sätt kunde förorsaka olyckor, vilka så småningom kunde leda till döden: 
Arne, 86 år, konstaterar att hemmet är farligt - Man skulle ju inte ha några lösa mattor! Han nämner att han ska ta bort de där stora mattorna i vardagsrummet, ibland har det varit några tillbud där i det rummet. Han berättar även om den gången när han ramlade i trappen. Det inträffade för ungefär ett halvår sedan, han skulle ta ner sängkläder, kuddar och täcken och sådant där, - Så när jag kommer ner då, det vill säga, när jag trodde jag var nere så gjorde jag det som man gör när man är nere, så ramlade jag med alltihopa bakåt [skrattar]!

Ibland förknippades även fysiska ting med tankar på döden. Det var inte ovanligt att föremål - möbler, fotografier, kläder och andra accessoarer, som hade tillhört en nära avliden anhörig och som sparats av intervjupersonerna - hade aktualiserat livet som varit och lett till funderingar på döden. För några infann sig dagligen sådana tankar då de såg eller vidrörde vissa ting. Någon berättade exempelvis att hon satte blommor framför de anhörigas porträtt på byrån för att minnas och hedra dem.

Nekrologerna och dödsannonserna i tidningarna var en annan källa till tankar på döden, även för dem som sade sig aldrig fundera på döden. Flertalet berättade hur de nu satt vid sina köksbord varje morgon och läste annonserna mer noggrant än tidigare under livet:

Förr i världen kunde man ägna i varje fall platsannonserna ett visst intresse. I dag läser man dödsannonserna i stället och i dödsannonserna ser man ju naturligtvis att det är väldigt mycket av sin egen årgång som förekommer där.

Dödsannonserna kunde också klippas ut, sparas och plockas fram för att minnas:

Inga, 91 år, berättar att hon då och då tar fram sparade nekrologer eller dödsannonser med fint skrivna dikter för att minnas de bortgångna, begravningarna och hur hon själv skulle vilja ha det.

Dödsannonserna spelade av flera anledningar en väsentlig roll för flera intervjupersoner. Det vanligaste skälet var att de tyckte det var viktigt att hålla sig à jour för att kunna agera korrekt om de skulle träffa på någon anhörig till en avliden. Ett vanligt resonemang var: "Vi vill hålla oss underrättade /.../ så är vi mycket angelägna att inte missa någon". Det fick absolut inte bli fel när man träffade en anhörig till någon avliden ute på staden och man fick inte glömma att skicka blommor till de anhöriga. Eller: "Jag måste hålla reda på vilka, så man inte ringer dem och så är de borta. Det är inte så bra". Göte, 83 år, berättade också att det fanns andra 
skäl till att han läste annonserna, till exempel av ren nyfikenhet eller helt slentrianmässigt för att se om han kände igen någon:

Jag kan säga det att det gör vi båda, min fru och jag, och vi tyckte inte om Dagens Nyheter då ett tag alltså, så vi gick över till Svenska Dagbladet alltså, men just, eller om man säger så här alltså att en stark bidragande anledning till att vi gick tillbaka till DN var det att i Svenskan hade de i stort sett inga dödsannonser och vi vill hålla oss underrättade.

Några deltagare berättade att de hade fastnat för en dikt, vackert skrivna nekrologer eller en symbol som de skulle kunna tänkas ha i sin egen dödsannons (jfr Dahlgren, 2000, s. 91):

Numera är det ju inte så vanligt med ett kors så här utan nu är det måsar och det är segelbåtar och det är AIK och det är allt möjligt. Nästan, ja det är allt alltså, man blir förvånad ibland.

Partiet har ju haft rosen. Nu har det kommit en ros som ligger ner. Har du sett den? Det har jag gjort. Röda, och den klippte jag ut och skickade till min gode vän för jag tyckte den var så fin. Ja, men sedan hade vi en ny dödsannons, vinjett, det var en strand, det var en oval så här och så såg man stranden bort. Himmelstranden eller som jag sa till henne, det kan vara Gotlandsstranden. Ja, ja, hon hade också sett den så hon hade klippt ut den.

I några av de intervjuades resonemang kring dödsannonser speglades både deras värderingar i livet men också vad man kanske hoppades på efter döden (jfr Rahm Hallberg, 2010, s. 88).

Hemmet var den plats där de intervjuades privata ritualer kring minnena av de döda pågick. Det var där en samling föremål gav upphov till minnen och där olika saker gavs symbolisk innebörd. Men hemmet var även en plats som kunde väcka funderingar på den egna döden, inte minst i samband med läsningen av dödsannonser.

\section{Naturen}

Naturen med dess växt- och djurliv tycktes för många intervjupersoner vara en plats för återhämtning och kontemplation, men även en plats som kunde framkalla funderingar kring liv och död. Nilsson, Sarvimäki och Ekman betonar i sin studie om äldres framtid: "They also made parallels between human life and life in nature, and were aware of themselves as being part of the cycle of nature" (Nilsson, Sarvimäki \& Ekman, 2003, s. 355). Årstiderna med sina cykliska inslag och naturens förgänglighet var något som återkom i berättelserna. Några menade: "Som nu lövsprickning 
och de här små grejerna som kommer nu till exempel, blommor och, får man uppleva det en gång till" och "man ser växterna spira där, det kanske är sista gången jag ser blommorna komma upp ur jorden där så här på våren". En kvinna sade att anblicken av en syrenhäck på våren fick henne att fundera på sin egen begravning och de blommor som kanske skulle pryda hennes kista. Erik, 70 år, berättade att han funderade på naturens förlopp och existentiella frågor:

Sätta ett frö vet du, så växer det en potatis eller en morot eller ett träd, alltså man kan ju undra, all denna kemiska process som pågår överallt, vad det är som har gjort allt det här? Om det är evolutionens miljoners miljoner år men hur började det en gång, varför just det här runda jordklotet, mitt ute i alltihop?

Naturens djur och växter kunde alltså väcka tankar om döende och död hos vissa intervjuade. Det handlade dock om en annan slags förgänglighet, det var inte direkt tankar om den egna döden eller andras död som frammanades utan snarare funderingar om världsalltet och om vad man skulle mista som död och om att inte längre få ta del av livets och naturens gång. Samtidigt handlade det också om vikten av att också få vara en del av detta världsallt.

\section{Det mediala rummet}

En annan "plats" som framkallade funderingar på döende och död var det mediala rummet. De intervjuade framhöll att möten med den död som förmedlades via TV, radio, tidningar, böcker och internet ofta var oundviklig. Några sade: "Man omges ju av död. Jag menar, genom media, framför allt TV förstås. Det är ju helt förfärligt, helt förfärligt" och "det är klart att det kommer upp olika saker som händer i världen runt i kring en och alltihop det där, det är ju inte så konstigt". Kort sagt, flera deltagare menade att de mer eller mindre dagligen överöstes medialt av nyheter som handlade om döende och död, att detta var "så massivt så det går ju inte att värja sig". Handlade det inte om mord, svält eller naturkatastrofer så handlade det i stället om cancerpatienters sista tid på hospice eller om äldre människors eländiga döende: "De slutar sina dagar som paket, oerhört beklämmande och många trista fall ser vi och läser om". Men media förmedlade också inslag, program, dokumentärer, bloggar, etcetera, som berörde existentiella och filosofiska aspekter av döden. Maja, 78 år, berättade att hon hade kontakt med en äldre kvinna på internet som led av en dödlig cancerart och att de diskuterade döende och död. Det hade börjat med att Maja fann kvinnans blogg på nätet och läste den och därefter svarade henne över bloggen, för att så småningom fortsätta att korrespondera 
med henne direkt via mail. Maja berättade att kvinnan bland annat rådgjorde med henne och ställde frågor om liv och död. Maja framhöll att det handlade om "sådana frågor som jag kan svara på". Några av de intervjuade ansåg att media var den enda arena i vilken döden synliggjordes $\mathrm{i}$ samhället. Utan denna mediala ström skulle döden i samhället förbli nästan osynlig. Andra menade däremot att det ständiga flödet av bilder på döden nästan gjorde dem resignerade, de orkade helt enkelt inte ta in mer - när döden i media blev för krävande gick det att "stänga av".

I vilken utsträckning påverkade medias skildringar av människors döende och död de intervjuades föreställningar kring döende och död? Det var uppenbart att det dagliga mediala förmedlandet av döden väckte deras tankar. Några menade att: "Ja, men där [i media] får man ju uppleva, där blir man ju påmind" - i synnerhet om det rörde sig om det döende och den död som var igenkännande. Någon nämnde - att en dokumentärfilm av Lasse Westman, som handlade om hans döende mor, "får en ju själv att tänka då på sitt eget yttersta så småningom, visst är det så". Det var inte heller ovanligt att inslag om exempelvis hospicevården och palliativ vård fick dem att fundera:

Man pratar ju rätt mycket om palliativ vård och det innebär väl då att man får en särskild uppmärksamhet /.../ för då skapar man ju en miljö för, och skapar förutsättningar för, för att ha det rätt så bra innan man dör så att säga.

Denna död, menade intervjupersonerna, handlade dock vanligtvis om andra "främmande människors" döende och död. Några efterfrågade $\mathrm{i}$ stället "vanliga mäniskors" döende och död i nyhetsrapporteringar. Kort sagt, någons död som de kunde identifiera sig med och inte bara kändisar, mördade, vanvårdade, etcetera. Några intervjupersoner undrade om äldres döende och död överhuvudtaget omnämndes i media: "Ja, det är det jag undrar. Nej, jag tror inte att det, ja inte som jag uppfattar i alla fall, att det står något speciellt och i vilka sammanhang skulle det stå annat än att det har varit något galet". En deltagare sade: "Det där med gamlingar är lite skrämmande naturligtvis för det är ju förgängligheten och det vill man ju inte ha med att göra". De flesta menade att nyheterna ofta handlade om hur äldre människor dog på sjukhem och äldreboende, att deras död oftast beskrevs i negativa termer - ibland var det tal om rena "skräckskildringar". Maja, 78 år, och Jens, 72 år, ansåg att medierna enbart gav en negativ stereotyp bild av de äldre generellt och i synnerhet de äldres döende. De konstaterade: 
Gamla ges i media en bild av tärande. Vi är tärande /.../ [men] vi är absolut inte tärande. Gamla ges ju en bild av att egentligen vara i vägen. /.../ Just den här attityden mot åldringar gör väl då också att det pratas inte om döden på annat sätt än som om det vore bra om de inte fanns. För då skulle det bli mycket bättre i samhället, tror man...

Det skrivs ju väldigt mycket om pensionärer och om ålderdom och så. Men om själva döendet vet jag inte. Alltså det man läser, det är ju sådana här skräckexempel alltså att - 98-årig man bodde hemma och han fick inte besök på tre dagar och så låg han avliden där och hade varit död i tre dagar och så här. Det är mer sådana där riktiga hemska händelser jag tycker mig se i medierna och typ det. Det kan ju vara andra förlopp också. Men någon egentlig beskrivning av själva dödsprocessen, det är väl inte så vanligt.

En slutsats som forskare framför är att döden i media får fungera som en ställföreträdande upplevelse av vårt eget döende och vår död - något som vi hela tiden försöker förtränga och hålla på avstånd - men även att "främlingars död förhöjer livskänslan" (Mazzarella, SvD 120530; Hirdman, 2012, s. 213ff). Kan jag då se sådana mönster i mina resultat? Främmande människors döende och död ledde visserligen till att döden synliggjordes och till eftertanke, men när de intervjuade inte kunde identifiera sig med denna död så förblev den också bara något flyktigt som knappast tycktes påverka dem. Rapporteringen handlade om andras död, vilket inte nödvändigtvis gjorde de intervjuade mer medvetna om den egna döden, eller motiverade dem till att förbereda den egna döden. Medias reportage om död verkade alltså varken fungera som en ställföreträdande upplevelse eller vara något som förhöjde deras livskänsla.

\section{Förluster}

Avsnitten ovan fokuserade i hög grad på funderingar kring det egna döendet och döden. Tankarna i vardagen kunde också handla om främmande människors död, döden som fenomen eller om närståendes död. Tankar på döda närstående uppstod i vardagen när de intervjuade upptäckte att den/de som de ville dela sina minnen med, sina vardagsupplevelser och sina framtidsplaner med inte fanns där längre, de var döda. Det handlade om de intervjuades relationer, eller snarare förlusten av sociala relationer till närstående som avlidit. De intervjuade hade under sin levnadsbana tillskansat sig skilda erfarenheter från olika sociala miljöer och även skapat livslånga sociala relationer som de hoppades ha med sig in i framtiden. Men ibland blev det inte så.

Detta förlusttema fick också en djupare mening när det tolkades mot bakgrund av deras resonemang kring sina sociala relationer med anhöriga 
och vänner:

Men visst betyder familjen och de närmsta väldigt mycket men också de gamla vännerna betyder ju mycket. Det är ju en kontinuitet över livet ändå, att vi har lyckats upprätthålla kontakten över livet på det sättet.

Om denna förväntade kontinuitet genom livet bröts kunde det bli förödande, det gick inte längre att se något sammanhang. Närmare bestämt tre mönster framkom i analysen - förlust av en gemensam nutid - förlust av ett gemensamt förflutet - förlust av en gemensam framtid. I analysen framkom att framförallt änkor gav uttryck för sin sorg över förluster även om det också förekom hos vissa andra intervjuade.

\section{Förlust av en gemensam nutid}

Några intervjuade gav uttryck för att funderingar på döden var förknippade med förlusten av närhet, det vill säga närheten till någons fysiska kropp, någons intellekt, någons känsloyttringar eller någons röst: "Ja, jag skulle gärna vilja att min man satt där!" Hemmets olika fysiska utrymmen eller föremål kunde väcka sådana funderingar. Britt, 79 år, som hade varit änka i ett halvår, berättade att hon och hennes make alltid hade suttit i källaren och tittat på TV i var sin fåtölj. Hon mindes sista gången maken satt i sin fåtölj och hon nämnde att hon en tid efter makens bortgång hade burit upp fåtöljerna ett våningsplan. Hon saknade närheten till honom när de tittade på TV tillsammans eller när de satt mittemot varandra vid köksbordet och åt frukost. Några av de intervjuade beskrev känslan av förlust över att inte längre kunna höra sin kärastes röst när hon kom innanför hemmets dörr, känna doften av sin livspartner eller över att inte mötas av ett välbekant ansikte på morgonen:

Det är tråkigt så till vida att man inte, när man kommer [hem] på dagen, inte har någon som möter en eller som finns där och man ska berätta om vad som har hänt ute och man vill diskutera en fråga och vilken ställning ska jag ta - men man har ju inte den chansen och det är väldigt tråkigt.

Frida, 72 år, som hade varit änka i drygt 10 år berättade att avsaknaden av makens skor innanför ytterdörren påminde henne om att livet inte varar för evigt. Förr visste hon alltid att de ofta smutsiga stövlarna på dörrmattan innebar att maken var hemma och att det medförde "ett hej" eller "en kram" i hallen. Nu för tiden blev frånvaron av dem en påminnelse om att maken inte längre fanns. Frida sade: 
Den där känslan när man kommer hem - även om jag nu kan sakna de där skitiga stövlarna på mattan som jag var arg på då - att det vore trevligt om han var där också men det är han ju inte. /.../ jag saknar min man förskräckligt mycket hela tiden. Fast det är så länge sedan [...] så saknar jag honom varje dag.

Ett par intervjuade nämnde att telefonen inte ringde lika ofta som förr i tiden, anhörigas och vänners röster hade tystnat för gott: "Så ska man gå och ta telefonluren, åh det måste jag ringa och berätta för henne och man vet ju - jag har ju inte kunnat ringa till henne på ett par år, hon är ju borta och ändå finns det här!" De menade att de knappt hade några att dela glädje och sorg med längre. Doris 78 år, berättade om sin bästa väninna som hon saknade väldigt mycket:

Hon var omedvetet rolig, hon kunde ringa fyra, fem gånger om dagen. Ooh vad trött jag blir! tänkte jag då och nu tänker jag - Tänk om Barbro ringde! Men det kan hon ju inte för att hon är ju i himlen eller väl ... bland andra.

Några intervjuade påminde sig själva om att de aldrig skulle få tillbaka denna närhet och att de måste leva med den insikten men försökte ändå med olika medel "kompensera" dessa förluster - exempelvis genom att plocka fram gamla fotografier på den bortgångne som de sedan pratade med ibland. Howarth menar i sin studie, att det inte var ovanligt att hennes intervjupersoner då och då pratade, kommunicerade med avlidna släktingar, och att de resonerade som att dessa släktingar var: "dead but not gone" (Howarth, 1998, s. 686; jfr Mulkay \& Ernst, 1991). Ett par deltagare i min studie berättade att de hade sparat både rörliga bilder och ljudinspelningar som de ibland kunde spela upp för att minnas röster. Det tycktes heller inte vara ovanligt bland de intervjuade att förvara några klädesplagg eller annat som hade tillhört den bortgångne och som fortfarande kunde ge upphov till en doftförnimmelse och en känsla av närhet (jfr Howarth, 2000, s. 135; Kellehear, 2007b, s.72f). Den här förlusten av närhet som de intervjuade gav uttryck för tycktes inte på något vis avta med tiden, snarare var det så att den ibland blev mer markant ett tag för att sedan mattas av igen. Gerd, 70 år, gjorde gällande att så kunde vara fallet:

Jag kan fortfarande alltså, efter 20 år, eller 16 år, ibland se folk på stan där jag tycker att jag kan se i kroppsspråk, alltså en människa som går som mamma eller som pappa eller så här, så att jag tänker ju på dem ofta... 
De intervjuades tankar rörande förlusterna av närhet tycktes handla om en förlorad gemensam nutid, eller med andra ord, att de saknade den döda närstående att dela nuet med.

\section{Förlust av ett gemensamt förflutet}

Några intervjupersoner tycktes då och då ägna sig åt någon slags tankemässig inventering av sina jämnåriga släktingar och vänner för att se vilka av dem som fortfarande var vid liv. Ett inte ovanligt konstaterande i dessa sammanhang var: "Det är så många som går bort när man är över 75 år". Var man då bortåt 85-90 år var nästan alla jämnåriga vänner och släktingar döda. En händelse som ibland gav upphov till en upplevelse av förlust hos intervjupersonerna hade att göra med den egna eller närståendes födelsedagar. De framhöll inte sällan att ju äldre de blev desto färre gratulanter dök det upp vid sådana tillfällen: "Som sagt, ja, när jag fyllde år här nu, i våras, då var det 31 personer som kom och det är rätt bra när man är 85 år. För att man har ju tappat en hel del [vänner och] de försvinner helt enkelt, de är borta, de dör. Det är klart att det känns." I samband med dessa inventeringar poängterade de att samtidigt som anhöriga och andra vänner dog så försvann också deras gemensamma minnen - "man märker att det är inte så många kvar som har minnen från den tiden". Karin, 90 år, sade: "Just det där lilla 'minns du' och det stämmer precis för att det är många saker som man skulle vilja säga, kommer du ihåg det och det..." Andra menade: "Men du vet, på det sättet blir man ju ensam, det finns ju ingen man tala med om de här minnena som man har, och kom du ihåg då och vad roligt vi hade då, allt det där, det finns inte. Jag kan inte tala om det med någon" och "man har inga gemensamma minnen eller man har inga gemensamma vänner, ja minnen har man väl, man har inga gemensamma upplevelser längre". Inga, 91 år, berättade att varje gång någon vän dog blev hon påmind om att det skulle bli allt svårare att återskapa det förflutna:

Inga nämner att det inte finns några vänner i livet längre som kan hjälpa till att minnas och upprätthålla livet de har levt tillsammans: "så dör ju alla runt omkring, i min ålder har jag nästan inte några kvar ... så att på det sättet så blir man ju ensam i sin generation..." Hon sörjer att hon inte längre har någon att dela sina minnen och erfarenheter med. Hon saknar sina döda vänner och anhöriga som nästan alla har försvunnit de senaste tio åren.

Förlusten av den gemensamma historien innebar inte att det förflutna i sig försvann från de intervjuades minnen. Fortfarande fanns just det förflutna i uttryck som "vilken tur jag har som fick leva med honom", "vad roligt vi 
hade" eller "vi var vänner länge, länge". Däremot reducerades möjligheten att dela minnena med andra människor i takt med att de närstående dog. Det blev svårare att bevara och dela en gemensam berättelse.

\section{Förlust av en gemensam framtid}

När det gäller förlusten av framtiden handlade den ofta om den framtid som inte, på grund av någon närståendes död, blev som de intervjuade hade hoppats på. Planerna och drömmarna om framtiden gick förlorade när döden inträffade. Närståendes död hade exempelvis omintetgjort de intervjuades möjlighet att i några fall se barnen växa upp eller möjligheten till ett långt liv tillsammans med maken efter pensioneringen: "Det ska vi göra när vi blir pensionärer, tänkte väl vi också, men vi fick inte bli pensionärer tillsammans". Frida, 72 år, berättade tårögd om sin make som hade dött av Alzheimers drygt 10 år tidigare, och Hilma, 76 år, berättade om sin make som dog 1972:

Det hade varit härligt om vi hade varit två. Så är det ju, för att det kan jag känna, jag kan ju vara arg på honom ibland och tänka - Vad sjutton, jag tog hand om dig men sedan stack du! Sedan är det min tur och då har jag ingen.

Så ibland när jag ska till hans grav på Hisingen, kyrkogården där, så står jag där och grälar på honom - Varför i helvete skulle du lämna mig så här! Så det är just det här att uppleva en sådan sak och veta att de blivande barnbarnen aldrig får uppleva sin farfar. Det är sådana saknader som man har.

En annan aspekt som några av de intervjuade nämnde var att deras barn hade dött före dem - döden inträffade inte "i rätt följd". Någon framhöll att: "Han kunde ju se framåt, det gör man ju inte i min ålder /.../ jag tänkte så här - om jag kunde ta det där [hans plats] i stället, för jag hade ju levt mitt liv" och "fast jag säger det att det var värre med barn, för att då är det precis som att de har tagit en bit av en. En man, det kan man skaffa en ny men det kan du inte med ett barn, aldrig".

Det tycktes som att de intervjuades tankar om förluster handlade om en förlorad gemensam framtid. Närmare bestämt de saknade de döda närstående som de ville dela planer och drömmar med inför framtiden. Tankar på döden i vardagen uppstod alltså många gånger ur saknaden efter döda nära och kära att dela sitt liv med. 


\section{Att hantera funderingar på döende och död}

Tidigare forskning om äldres döende och död handlar mycket om att de "förhållningssätt" och de "förberedelser" äldre har/gör inför den egna döden. Val av begravningssätt, hur begravningsceremonin ska genomföras, sätt att reflektera över sin död, registrering i donationsregistret, etcetera utgör olika strategier inför döden för att på det viset få en slags kontroll. I litteraturen skildras flera strategier som kan övervägas - bland annat eutanasi, planera sitt döende och skriva testamente:

A great fear expressed by the older people in our study was not knowing how or when they die. Some would rather die than lose their independence. Others felt stronger about controlling their death. John had strong feelings around the subject euthanasia (Lloyd-Williams et al., 2007, s. 63).

A strategy of coping with one's eventual death by suppressing or denying the existence of possible negative events during the dying process precludes any thought or planning about improving the quality of life while dying (Cicirelli, 2006, s. 346).

Margaret expressed the view that writing a living-will had made her feel more in control of her life (Clarke \& Warren, 2007, s. 478).

Giddens menar att det hos människan finns ett ständigt behov av att närma sig existentiella frågor som handlar om död, liv och existens. Genom att hon "medvetet utformar 'svar'" på de här frågorna uppnår hon en ontologisk trygghet - en känsla av tillit till sin omgivning och en känsla av att kunna hantera och kontrollera svåra ämnen (Giddens [1991] i Johansson, 2004, s. 423, 440, 446). I detta avsnitt använder jag begreppen hantering, kontroll och inre strategi rörande de "förberedelser" äldre gör, vilka har sin grund i de erfarenheter av döden som de intervjuade har införlivat genom livet. Att hantera och kontrollera döende och död handlar om en livslång process, som inte tar slut förrän döden inträder.

Den fråga som jag diskuterar i följande avsnitt är: På vilka sätt hanterade de intervjuade sina funderingar på döende och död? I de tidigare avsnitten visades att funderingarna kretsade kring huruvida det var tid att tänka på döden eller inte, vilka platser som framkallade tankar på döden och om förluster av olika karaktär. Sätten att hantera tankarna handlade däremot ofta om att "medvetet utforma - svar", fatta viktiga beslut, göra olika överväganden för och emot för att uppnå trygghet. De intervjuade hanterade detta både i tankarna och praktiskt när det gällde såväl döende som död. Rahm Hallberg menar att äldre människor i större omfattning förbereder sig inför sin egen död än vad som är fallet inför sitt eget dö- 
ende. Hon anser det som anmärkningsvärt "eftersom det är döendet som tycks mest förknippat med ångest och farhågor om lidande och existentiell smärta" (Rahm Hallberg, 2010, s. 101). Cicirelli, däremot, påpekar att tidigare forskning "indicates how important it is for the elderly to feel a greater sense of control over when, how and where they will die", men nämner att i den egna studien "did [older adults] not seem to feel that control of the dying process itself was important" (Cicirelli, 2006, s. 350).

Fem mönster framkom i analysen - att inte dö nu - att slippa det långsamma döendet - att slippa dö ensam - att "dödsstäda" - att planera inför "den sista föreställningen".

\section{Att inte dö nu}

Ofta medförde läsning av dödsannonser att de intervjuade började fundera på de avlidnas ålder. Några sade: "Jag tittar på födelseåren i dödsannonserna, det gör jag. Då tänker jag att ja, vi får se hur länge det fungerar" och "vad ung hon var, och titta så gammal den människan har blivit". Att dö vid 30, 50 eller för all del även vid 70 års ålder var alldeles för tidigt, ansåg flertalet, men dog man däremot vid 85-90 års ålder var det mer naturligt och mindre problematiskt. De intervjuade förknippade alltså döden med ålderdomen. Några sade också: "Det är inte så underligt att vännerna försvinner, de är ju lika gamla som jag" och "det är väl den äldre generationen och då liksom är det naturligt att den äldre ska gå bort, konstigt nog". Att associera döden med ålderdomen är inte någon ovanlig företeelse. I vår tid och i vår del av världen anses det vara rätt tid att dö när man är gammal (Howarth, 2007, s. 52). Döden har "förflyttats till den fas i livet där den naturligen hör hemma, det vill säga, ålderdomen" (Rahm Hallberg, 2010, s. 87).

På något vis hade medellivslängden antagits som en slags norm hos de intervjuade. Hade inte den passerats så ansågs man ha dött för tidigt. Flertalet trodde sig kunna passera denna statistiska tidtabell för när döden borde inträffa, medan några redan hade passerat den och hade förhoppningar om att få leva flera år till (jfr Bringéus, 2007, s. 225). Olga, 85 år, hade en förhoppning utifrån egna erfarenheter:

Det är väldigt beklagligt, som för min bror till exempel att gå bort före 50 år, det ska man inte göra. Men när man är 90 så tycker jag att det är berättigat. Det kan det vara när man är 85 med för den delen. [småskratt] Fast jag har inte lust än...

De ansåg även att det var mer "tragiskt och orättvist" när en ung människa dog än vad det var för en äldre. Några påpekade att "det är för jävligt att de ska dö, om de dör unga", "det är värre med unga människor som 
går bort" och "det är ju synd och det är inte klokt, och titta de har två barn och lite sådant där". Ett sätt att resonera som betraktats som det normala under de senaste decennierna i den här delen av världen (Jecker \& Schneiderman, 1994, s. 66ff). Som en konsekvens av resonemanget ansågs det som något naturligt, okomplicerat och accepterat när äldre dog medan det ofta beskrevs som onaturligt, förfärligt och meningslöst när yngre dog. Ett typisk påstående bland de intervjuade var: "När man blir äldre så blir det lite granna mer naturligt, och därför så upplever man det lite onaturligt när det är unga människor som dör." Följaktligen fanns det en viss acceptans i förhållandet till döden - att var man äldre och gammal så var det "on time" att dö, för då hade man levt ett långt liv. Dessutom innebar ett långt liv att man kanske hade fått vara med om ofantligt mycket under denna resa - och att man kanske inte hade så mycket mera att bidra med varken för tillfället eller i framtiden. Parallellt med denna uppfattning fanns en slags utbredd icke-acceptans som förmedlades av flera intervjuade och som handlade om att det inte var "on time" för just dem att dö än. De menade visserligen att de inte var så unga längre men de kände sig däremot vaken gamla eller sjuka.

På något vis ville de intervjuade förmedla att döden hörde ålderdomen till, det vill säga den utifrån livsloppet förväntade döden, men samtidigt också understryka sin egen förväntan som innebar att det inte var aktuellt att dö för just dem på ett tag. Någon påpekade att: "Nej, utan man tycker väl alltid att det [döden] är väldigt långt bort. Väldigt långt bort och det gäller inte mig, det, på något sätt!" De ansåg sig på något sätt tillhöra undantaget, det vill säga, att andra kunde hamna på äldreboende och dö, men det gällde inte för dem själva i dag, här och nu (jfr Jeppsson Grassman \& Whitaker, 2012; Whitaker, 2009).

\section{Att slippa det långsamma döendet}

I möten med döende och döda närstående på sjukhus och äldreboenden aktualiserades ofta existentiella funderingar på döende och död. Vanligtvis gjorde intervjupersonerna en distinktion mellan tillstånden döende och död: "Döden är mera definitiv och döende är ju processen innan. Så det är två skilda saker, tycker jag." David, 73 år, beskrev mer känslomässigt vad han avsåg med begreppen (jfr Rahm Hallberg, 2010, s. 89ff):

Själva döendet är nog mera skrämmande än döden, vad som kommer att föregå, visst är det så, att döden är nog mindre skrämmande än döendet. För att man undrar ju hur, om det ska göra ont eller om man ska behöva ligga och plågas på något sätt. 
De här offentliga institutionerna fick sålunda flera av de intervjuade att börja fundera kring den egna döden. Ett vanligt påstående var att de upplevde döden som definitiv, men att de däremot inte kände någon större rädsla inför döden: "Det skrämmer mig inte särskilt mycket", "det är ett naturligt händelseförlopp" och "jag vet inte, om man lurar sig själv men någon direkt rädsla tror jag inte att jag känner". Isak, 75 år, konstaterade att han efter sin frus bortgång inte upplevde någon rädsla längre inför döden:

Min syn på döden är klar, har förändrats med stigande ålder helt klart och det är klart när min fru gick bort att det blev en aktualitet, att livet inte är evigt på något sätt eller att man kunde skjuta på den frågan, men nu, den kan komma när som helst. /.../ Jag upplever inte någon dödsskräck...

$\AA$ andra sidan fick tankarna kring det egna döendet - "passagen till döden" - en helt annan uppmärksamhet än döden i de intervjuades berättelser (jfr Clarke \& Warren, 2007, s. 478; Rahm Hallberg, 2010, s. 95). Möten med skröpliga och döende närstående på äldreboenden och sjukhus gav ofta upphov till funderingar som handlade om hur den allra sista tiden av det egna livet kanske skulle komma att gestalta sig. Inte sällan ställde de två tänkta scenarier eller två bilder av döendet mot varandra. Den ena bilden handlade om det döende som de själva skulle vilja vara med om och som de ansåg vara det mest ideala sättet att få dö på, medan den andra bilden handlade om det döende de hade förhoppningar om att kunna undvika det skrämmande döendet.

Den ena bilden handlade sålunda om förhoppningar om att: "Dö i språnget", "hålla mig frisk ända tills jag dör", "jag vill bara dö snabbt, det vill väl alla", "döden ska inträffa fort", "lugnt och stilla tillväga", "bara slockna". Man skulle alltså vilja "dö levande" (jfr Gunnarsson, 2009a; 2009b). David, 73 år, och Erik, 70 år, berättade hur de ville att slutet skulle gestalta sig och var de ville dö denna död - långt från platser som förknippades med äldreboende och sjukhus:

Ja, jag skulle vilja dö plötsligt sådär som [min frus] farfar som byggde det här huset /.../ de var ute en söndag eftermiddag och plockade smultron och gick hand i hand och hade det småtrevligt och sedan på natten så dog farfar. Så dagen efter var han hemma, eller borta. Det låter ju som ett idealiskt sätt att dö.

Brukar säga, det bästa är om man dör på väg till jordkällaren för att hämta potatis. Det är ju det lindrigaste. 
Dessutom skulle inträdet i döden helst ske "på natten när man sover", eller som Jenny, 85 år, berättade:

Jag vill somna in i min egen säng. Mm, sova, direkt in i döden. Det tycker jag är minst skräckinjagande i den mån man vill undgå ångesten.

De intervjuade framhöll ofta den ögonblickliga döden som nästan skulle komma och överrumpla dem utan att de alls märkte av den som det önskvärda. Samtidigt ansåg de att detta var "lite själviskt kanske att säga att jag hoppas att det går fort. Ja, det är själviskt". De föredrog således att "inte vara där" när det skedde, att inte stå öga mot öga med döden. Några menade dock, efter att ha resonerat en stund, att det vore bra att få tid att ta farväl av sina anhöriga: "Det är väl bättre att på något sätt att det är annonserat lite i förväg då så att säga. Man kanske inte vill dö ensam, det är möjligt att man inte vill".

Den motsatta bilden av döendet - som framträdde i deras berättelser och som de hade förhoppningar om att undvika - handlade om lidande, bräcklighet, kroppsligt förfall, ligga andra till last och att inte längre ha kontroll. Framförallt erfarenheter av äldre närståendes sista tid i livet på äldreboenden formade bilder - skrämmande framtidsscenarier - av ett döende de helst inte ville genomleva. Ett vanligt förekommande påstående var: "Jag vill inte ligga i en säng och dö länge, länge", " att man slipper både sjukdom och plågor" och "bara man inte har ont, för att det ockuperar hela sinnet". Eller som Karin, 90 år, valde att uttrycka sig: "Inte långvård, vad som helst men inte långvården. Av den anledningen så är jag rätt så fräck när jag går över gator och så där". Ofta handlade det om rädslan över att förlora kontrollen över kropp, förnuft och medvetande. Jens, 72 år, sammanfattade denna rädsla:

Alltså att vistas i något sådant limbo-tillstånd där man inte vet vad de närmsta heter och så där, det måste jag säga, det känns lite skrämmande om man skulle behöva hamna i en sådan situation. Då är inte livet värt att leva, tycker jag.

Skulle de intervjuade trots allt bli liggande på ett sjukhem så "vill man ju helst ha det någorlunda skonsamt. /.../ det är ju bara en förhoppning att det skulle kunna ske under någorlunda värdiga former" och få chansen "att säga adjö till sina närmaste". För att undvika ett scenario med långsamt döende var några inne på följande resonemang: "När man ligger och får narkos, jag är mycket för narkos, för att jag har den inställningen att jag inte ska plågas för något, för att då ska jag ha hjälp med det" och "ja, få tabletter eller något sådant där". Andemeningen var att de ville få hjälp att dö om det skulle visa sig att de skulle hamna i en utdragen döendepro- 
cess. Det är ett resonemang som också framkommer i andra studier om äldre: "In regard to pain, they felt that powerful medications would alleviate any concern for pain" (Cicirelli, 2006, s. 350). Malte, 80 år, hade också en åsikt kring detta fenomen, men ett mer radikalt sådant:

Det hoppas jag verkligen att om jag behöver ha omsorg och jag blir som ett paket så hoppas jag att jag kan svälja en plastpåse så att jag dör. Tänker inte försöka ligga kvar och någon ska hålla på och svära över mig att: - Har du skitit på dig nu igen!"

De intervjuade ville slippa det utdragna döendet, och hoppades att få dö i språnget och kunna undvika det lidande som flera förknippade döendeprocessen med - en önskan om trygghet och en värdig död.

\section{Att slippa dö ensam}

Ett återkommande inslag i de intervjuades berättelser handlade om huruvida det var väsentligt att någon skulle finnas med vid deras bortgång (jfr Cicirelli, 2006, s. 351). Några sade att de aldrig hade funderat på detta, medan flertalet någon gång, ofta i samband med ett dödsfall, tycktes ha funderat. Vanligtvis framkom två framtidsscenarier, ofta med de egna erfarenheterna som referenspunkt.

Å ena sidan och trots att flertalet närde förhoppning att döden skulle ske "knall och fall", så ville de slippa dö ensamma. Skulle döden inträffa utan anhöriga och vänner vid sidan så ville man i alla fall ha någon vårdpersonal i närheten, bara man slapp att dö ensam. Flertalet sade sig också vilja dö hemma. Det var ofta minnen från och erfarenheter av närståendes dödsfall som återspeglades i deras resonemang. Hade de mist någon nära släkting och samtidigt själv varit med vid dödsögonblicket och ansett det vara en värdig avslutning, så hade de också en förhoppning om att den egna döden skulle få ske på detta vis - tillsammans med någon eller några anhöriga. Asta, 77 år, nämnde: "Min man dog år 2000, han ramlade här på golvet och dog direkt" och "jag hoppas när jag dör att det går fort och att det är någon som är hos mig". Frida, 72 år, mindes också att dödsögonblicket kunde upplevas som en värdig stund:

Ja, barnen förstås, det skulle jag ju vilja, om de orkar och vill, beror på situationen så klart. Det skulle jag ju vilja så klart. För det har ju vi försökt, så det har blivit lite tradition eller vad man ska kalla det, det låter ju hemskt men ändå, du förstår hur jag menar.

Erfarenheter av, som de sade, ovärdiga dödsfall förekom också. Några hade erfarenhet av släktingar som hade fått ligga döda länge innan de 
hade blivit upptäckta:

Så det inte blir som när jag hittade min faster död, hon hade legat i tre dygn och någon kunde inte ta i henne. För det var förskräckligt, och det var midsommarafton förstår du, det var varmt som bara attan...

Skulle det visa sig att döden inte inträffade ögonblickligen utan skulle bestå av en utdragen döendeprocess, ansågs det viktigt att ha med anhöriga vid dödsögonblicket. David, 73 år, resonerade kring detta att vilja ha stöd av familjen vid en eventuell döendeprocess:

Vid döendet så inser jag ju att jag kan ha stöd och hjälp av personer omkring mig och då betyder det ju någonting vilka det är förstås [...] det är ju mina barn då, i första hand som jag skulle vilja och önska ha stöd utav, under döendet. Men idealet är kanske att det plötsligt inträffar, utan att behöva föregås av lidandet och smärtan och ångesten.

Det verkade till och med som att det innebar en fördel att inte få dö "knall och fall", för vissa intervjuade. Hilma, 76 år, resonerade:

Men döendet då har man kanske om man har lite grann kvar, det är väl den här sista tiden som kanske är viktig om man nu har sinnet $\mathrm{i}$ behåll så att man kan tänka till så att man kanske helst, om man har möjlighet när den sista tiden kommer, att man har möjlighet att säga adjö till sina närmaste. Men annars, det är nog det där som är det viktigaste i så fall, tror jag. Oavsett att jag inte har kunnat leva så nära dem, men sedan att sista, sista tiden någon gång skulle jag kunna träffa alla, innan.

Å andra sidan menade några att det inte spelade någon roll om de skulle vara ensamma vid bortgången. För ett par av dem var det första gången som de överhuvudtaget funderade på frågan. Bertil, 84 år, förde ett resonemang:

Nej du, det har jag nog inte tänkt på alls, det har jag nog inte tänkt på alls. När du väcker frågan, så skulle en ju kunna tänka sig att, nej, nej, det kan jag nog säga att det har jag inte tänkt på ... nej... Om det är en sjuksköterska eller om jag är ensam eller om det är, det vet en ju inte, en vet ju inte i vilket skick en är, om det är så att omständigheten är så att det krävs en som alltid är där eller om de kan lämna en. /.../ Men i mitt fall, nej, det, det spelar ingen roll...

Några återkom till att det var en fråga som de närstående fick ta ställning till: "Nej, det tycker jag inte jag kan kräva. Nej, det får nog vara ett initiativ utifrån". Någon antydde att hon hellre ville dö ensam. "Ja, kanske höll jag 
på att säga, hellre ensam än några som jag inte har några - förstår du vad jag menar - känslor för /.../ fullständigt främmande eller, ja inte ovänner men i alla fall några som man inte tycker är så himla kul. Jag är hellre ensam!"

De flesta intervjuade ville ha någon vid sin sida när de skulle dö. Att fundera kring sitt döende på detta vis var ett sätt att hantera tankarna/rädslan inför att dö ensam (jfr Elias, 1985), men också uttryck för en önskan om att få dö värdigt.

\section{Att "dödsstäda"}

Några intervjuade berättade om att de "dödsstädade" varje dag. Innebörden av denna "dödsstädning" var att den egna döden inte skulle få inträffa under vilka omständigheter som helst. Döden fick till exempel inte inträffa när kaos eller oordning rådde i hemmet bland diverse föremål och dylikt. Det kunde handla om till synes banala företeelser. För några var det mer betydelsefullt att hemmet var i ordning än att ha den egna begravningen färdigplanerad. Innebörden i deras resonemang var att när de anhöriga anlände så skulle hemmet vara i klanderfritt skick. En av de intervjuade menade: "Ja, det är klart jag vill ju ha gått ut med soporna /.../ och jag skulle ju helst önska att jag inte hade så mycket i tvättkorgen utan att den var tom och lite annat undanplockat...". De här intervjupersonerna gjorde sig dagligen redo genom att iordningställa hemmet inför, så att säga, avresa. Andemeningen tycktes vara att - det är min tur nu, det kanske är dags i natt. Det skulle ha varit en lämplig tidpunkt i livet och dessutom rätt plats att dö på och då skulle det vara städat och undanplockat. Celia, 86 år, sade att det var dags nu:

C: ... det är så löjligt, jag vill ha undanplockat allting när jag går och lägger mig på kvällen, det ska inte vara något framplockat, och bråte. Likadant som nu, förstår du, jag går här och river i mina skåp och schyss, skickar iväg saker som jag inte använder och så där, gör jag nu... Jag tänker: "Nej, jag kanske inte, de ska inte ta mycket efter mig". Sådant är dagligen...

M: Så det här med döden är tankar som dagligen...

C: ... Ja, det är faktiskt tankar ... i och med att det ger uttryck i det. Det ska vara ordning och snyggt, undanplockat och det ska inte vara en massa jox och sådant där.

Det fanns även andra sätt att "dödsstäda" på som inte handlade om en dagligen återkommande åtgärd, som ovan, utan något som genomfördes då och då (jfr Gunnarsson, 2009a; 2009b). En av de intervjuade menade: 
"Det är ganska populärt, åtminstone här i staden, att folk dödsplanerar. De säljer tavlor och bokhyllor och sådant, böcker, till det de oundgängligen behöver" - för att ha råd med det där allra sista i livet som de önskar - kanske en resa, eller något annat. En deltagare exemplifierade: "Att vi skulle sälja sommarstället så vi slapp det och börja åka med i lite mera bussresor runt om i Sverige och så vidare". Med andra ord ett sätt att sätta guldkant på tillvaron. Det kunde också handla om att få ordning på saker och ting, att inte bara lämna allt $i$ en enda röra åt de efterlevande: "Hinna sortera alla kort som ligger i en låda bara". Några berättade också att de hade börjat göra sig av med allt fler prylar och saker för att närstående inte skulle behöva reda i det efter deras död. Hemmets föremål kunde också medföra problem, det fanns nämligen en uppsjö av ärvda ting $\mathrm{i}$ hemmet som ansågs vara klenoder och som hade ett affektionsvärde för dem, men som varken deras barn eller barnbarn tycktes vara intresserade av att ärva. En av åtskilliga bilder som förmedlades var: "Det går inte att komma med en kristallvas längre och säga, nu alltså, den här ska du vara rädd om för det är klenod och så vidare...". Det påpekades dessutom att det inte var alldeles okomplicerat när de kände sig fullt friska att gallra i hemmet bland föremålen:

Vi har ju en del gamla grejer som vi kanske, kanske man skulle tala om lite hur vi vill, men det har vi inte gjort än. Och det är väl kanske så att man kanske inte gör det förrän det är försent, det är ingen som har prioriterats.

Däremot funderar jag på att jag skulle nog skulle kunna träffa de här båda systerdöttrarna och berätta lite mer om saker och ting, vad de skulle göra till exempel med mitt bohag när jag är borta. / ... / Men det, jag måste säga det, det bär en lite emot då att ta det steget. Därför att det är ju ett bevis för att nu gör jag det här, det betyder ju att jag är någonstans i livets slutskede $\mathrm{i}$ alla fall, eftersom jag gör en sådan åtgärd. Så att det är inte roligt direkt, men nödvändigt, jaa...

Flera intervjuade ansåg att det var viktigt att "städa undan" om, mot förmodan, döden skulle komma plötsligt.

\section{Att planera inför "den sista föreställningen"}

Ett sätt att hantera och ha kontroll på döden handlade om de intervjuades planering av "den sista föreställningen". Hur skulle begravningsceremonin se ut, vad för kista ville man ha, vilken typ av gravsättning, etcetera. Det fanns flera perspektiv på denna planering bland intervjupersonerna. 
För det första - Några av de intervjuade sade att de nästan aldrig hade funderat kring sin egen begravning. De tycktes anse att det ordnar sig med tiden, det fick livspartnern och barnen bestämma över eller "kremering blir bra, det har vi använt tidigare". Det fanns alltså en ovilja: "Ja, det är ett motstånd". I vissa fall tycktes det handla om ett ointresse. Någon menade: "Jag har ingen stark preferens. Jag skulle tippa att kremering blir mitt alternativ utan att ha ägnat frågan någon större, skulle jag ställas inför frågan just nu, så tror jag kremering". Någon nämnde: "Men jag har inte kommit till skott" gällande planeringen av den egna döden, och "det är konstigt tycker jag, att man kan ha idéer om hur man vill att det ska bli och var man vill bli begravd någonstans". Bertil, 84 år, ansåg att "det ska jag göra, alltså om jag hinner". Det fanns flera skäl till resonemanget. En återkommande tolkning var att de gav uttryck för att det inte var "on time" för sådana här funderingar nu och framförallt inte beträffande konkretiseringen av dem. En deltagare sade: "Ja, det är svårgripligt det här, det tycker jag. Det är ju inte så svårt att inse att livet inte är evigt och jag tror inte på något liv efter döden, men ändå börja formulera några önskemål och åtgärder, det tar emot faktiskt”. Det var lättare att i stället låta anhöriga få ta ansvaret och kontrollen över deras död när de hade lämnat det jordliga, tyckte några deltagare. De påpekade: "Nej, det överlåter jag till mina efterlevande", "nej, nej, det har jag inte gjort, det får väl de andra göra" och "jag tycker det är mer en affär för de anhöriga".

För det andra - Ett motsatt förhållningssätt som kom till uttryck hos mina intervjuade handlade i stället om att det kanske var "on time" att faktiskt börja fundera över den sista delen av livet: "Man kan inte stoppa huvudet i busken och säga att, det kan aldrig hända mig", att på något vis få sina tankar konkretiserade: "Kanske man skulle passa på att fästa på papper då, lite mer" eller "gå igenom de här begravningarna som jag har varit på, och speciellt psalmer som man tycker om och /.../ sedan kanske plagiera lite som jag tyckte speciellt mycket om". Isak, 75 år, uttryckte det på följande vis: "Nej, jag har inte, fast när du säger det, jag har hört folk säga att det är bra att ha det [Vita Arkivet]. Men då krävs det att man plockar fram ett förslag och sätter [fart] i högsta hugg. Kanske jag borde överväga". Åldern vara alltså en aspekt som togs med i beräkningen, det vill säga, en hög ålder var ett argument för att fylla i det Vita Arkivet - döden kunde vänta runt hörnet, men samtidigt innebar ett ifyllt dokument att förhållandet till döden blev konkretiserat och alltför närvarande. Inga, 91 år, resonerade på följande vis om Vita Arkivet: 
Ja, jag tror det har nog med åldern att göra. Inte det att man inte kan göra det men det är någonting som säger att, nej i morgon, kanske nästa vecka, men då säger man så här, men då måste jag ju faktiskt göra det. /.../ men det är inte klokt att man inte sätter sig ner, tar det där och säger att så här kanske och de här sångerna. Nej, ja, jag börjar bli rädd för mig själv för att nu är det hög tid att göra det. Oavsett, det kan hända vad som helst vilken dag som helst, det kan det ju hända om man är 60, 70 också, men ändå. /.../ Ja, så det är mitt stora bekymmer och jag vet och det måste jag göra, det kommer jag göra också. Men när, det vet jag inte, kan inte lova. Men det ligger ganska högt upp på listan. Jag lovar.

För det tredje - Ytterligare ett förhållningssätt handlade om att nödvändigheten - om än inte direkt roligt - att förmedla de egna önskningarna om hur man ville ha det i livets slut till anhöriga. Utifrån de intervjuades berättelser förstod jag även att ett par av deltagarna alldeles nyligen hade, någon gång mellan min första kontakt med dem per telefon och vid själva intervjun, påbörjat att skriva ner sina funderingar. Jenny, 85 år, berättade att hon ganska så nyligen hade gjort sina val:

Ja, jag pratade med min goda vän på begravningsbyrån då, gått igenom alla detaljer och att de ska ha kaffe och snittar här när jag, kyrkklockorna har ringt ut mig, så ja, precis alla detaljer har vi gått igenom. Jag vill inte ha fanor. Det har, ibland så vill både PRO och partiet komma med fanor, det tycker jag [inte] är [angeläget] nu. Det behövs inte. /.../ på kyrkogården, det finns en minneslund där och har jag gjort allt annat där under alla år så ska jag väl ligga där också, jadå, och det har jag skrivit in. Och jag har skrivit in vem som ska jordfästa mig och så vidare, jadå. Jag tror inte jag har glömt någon detalj.

Några hade emellertid tagit dessa beslut kring livets sista tid för länge sedan, ofta i samband med anhörigas bortgång. En av de intervjuade nämnde: "Jag har ju, ja, vad kan det vara, det är ju rätt många år sedan jag gjorde mina önskemål om slutskedet", och en annan sade: "Västergötland, jag har löst in en gravplats där [i byn bland släktingar] /.../ Det är klart jag måste ligga där också. Och det ska stå på min gravsten till exempel: landsting, tingsrätt, hembygd. /.../ Jo, men det är viktigt. Och det ska inte vara kremering utan det ska vara en riktig gammaldags begravning. Och så ska det vara kalas". Det fanns flera argument menade de intervjuade, att vara "ute i god tid" med sina önskemål angående livets slut. Det kunde underlätta för anhöriga: 
Det är ju något som vi inte kan komma ifrån, döden, och det var ju det jag tyckte jag ville komma fram till med mitt Vita Arkiv eller vad jag ska kalla det för - att göra det lätt för de efterlevande.

Det tycker jag, som sagt, eftersom jag har upplevt mina föräldrar och allt vad det betydde, rent praktiskt, så tycker jag man ska underlätta så mycket som möjligt i det fallet faktiskt. Det tycker jag egentligen är det viktigaste. Om man tänker på eftermälet så att säga. Så att man inte gör det alltför krångligt för de stackarna som ska ta över.

En annan anledning som nämndes var att få lugn i tillvaron och att få det överstökat "medan man vet vad man gör". En av de intervjuade berättade att hon ett par veckor tidigare hade besökt begravningsbyrån och fyllt i det Vita Arkivet. Efter den händelsen hade det infunnit sig ett lugn:

Jag själv har förberett mig rent praktiskt. /.../ Så tillvida så har jag gått igenom Vita Arkivet väldigt ordentligt och hoppas att jag täcker upp det. Och förberett - så tillvida har jag förberett mig själv. Ja, och känner mig lugn inför det, att om det skulle hända något så vet både mina barn och den här gode vännen på begravningsbyrån hur jag vill ha det.

Ett annat argument för att fylla i det Vita Arkivet eller ett testamente var att förhindra att anhöriga skulle bli ovänner och "behöva gräla" - "det kan bli förfärliga tragedier rent av". Någon sade: "Jo men det är ganska viktigt och det är ju för att slippa att de ska komma i massa diskussioner i efterhand, vad som gäller och sådär. Kanske blir så ändå, det vet jag inte, men jag tror inte det" och "om de kan komma överens men det får jag väl hoppas att de kan".

Planeringen tycktes inte alltid vara helt oproblematisk. Några nämnde att de var svårt att besluta sig för vad som skulle stå med i det Vita Arkivet. Elsa, 71 år, menade: "Jag kanske ändrar mig varje gång när jag hör [musik] på radion, det kan komma en klämkäck och det kan komma något som är väldigt fint". För några intervjuade gjorde döden sig lite mer påmind i vardagslivet genom den vardagliga relation de hade till det icke ifyllda Vita Arkiv-dokumentet som stod i bokhyllan. Gerd, 70 år, sade:

... och nu ska jag berätta någonting som är paradoxalt, jag har, det är säkert ett par tre år sedan, har jag alltså ett vitt arkiv i mitt hem, i ett brevställ som jag alltså inte har fyllt i. Jag kommer mig inte för att göra det. Jag vet inte varför det ska vara så trögt och vad som ska få mig, alltså jag ser det varje dag, och jag kommer mig inte för att ta ner det och skriva i hur jag ska ha det. Det är ju så dumt eftersom jag tyckte det var så bra att mamma hade gjort det. Jag har inte pratat med mina barn riktigt om det här. 
Detta var ett tema som återkom i flera av de intervjuades utsagor, nämligen att dokumentet fanns i hemmet och påminde dem ofta om döden, och att dess syfte var att underlätta för de efterlevande, men att de av någon anledning inte ville konkretisera sina önskemål. Hilma, 76 år, nämnde angående det Vita Arkivet, och den utdragna process som ännu inte hade lett fram till något ifyllande, att hon hade haft dokumentet hemma i: "Säkert 10, minst 10 år. Kanske ännu, ännu längre".

\section{Sammanfattning}

Detta kapitel har handlat om de intervjuades tankar på döende och död i vardagen. Forskningsfrågorna jag fokuserade var: Hur ser äldre människor på sitt eget döende och på sin egen död? - Vilka erfarenheter har äldre människor av möten med döende och död $i$ det vardagliga livet? En fråga som ställdes var om man överhuvudtaget funderade på döende och död i vardagen, och vad i så fall dessa funderingar handlade om. Vidare behandlade kapitlet var och i vilka vardagliga situationer sådana tankar uppstod och hur man hanterade dem.

Funderade de intervjuade på döende och död $i$ vardagen? Ja, några av de intervjuade funderade dagligen på döden. Andra funderade då och då, medan några sade sig nästan aldrig tänka på döden. Två motsatta mönster framkom speciellt i analysen. Det första handlade om en tidsmässig anpassning till det "normala" livsloppet - funderingar och tankar på döden som man förväntades ha vid den här tidpunkten i livet. Tankarna var faktiskt så att säga "on time" vare sig man var 70, 81 eller 91 år. Lika viktigt var det, menade de intervjuade, att bli påmind om den egna dödligheten och leva med den, vilket går lite stick i stäv med den implicita underton som är inbäddad i tredje åldern begreppet. Där handlar det mycket om att vara oberoende, frisk, aktiv och eftersträva självförverkligande - döden får nästan inte alls något utrymme. Det andra motsatta mönstret handlade om att den livsfas man befann sig inte bedömdes vara "on time" för att ha tankar på döden vare sig man var 70, 80 eller 91 år. Dessutom påpekades att det varken fanns tid över för sådana tankar eller att det var meningsfullt att fundera på döden i vardagen då man kände sig fullt frisk. Att ha tankar på döden tycktes i högre grad vara något som förknippades med det som kallas fjärde åldern - det vill säga när man var skröplig eller döende men inte i den livsfas de befann sig i nu - i tredje åldern. Några tydliga åldersmönster bland de intervjuade när det gällde funderingar i vardagen på döende och död kunde inte skönjas.

Var och $i$ vilka sammanhang och situationer uppstod tankar och funderingar på döden och vad handlade de om? Framförallt fem platser blev synliga $\mathrm{i}$ analysen. Kyrkogården var den offentliga plats där personliga ritualer kring minnena av de döda utspelade sig. Man mindes och skapade min- 
nen kring de döda anhöriga när gravarna pyntades. Kyrkogården var också den plats som sammanband funderingar kring tidigare generationers död med den egna kommande döden och de existentiella frågorna om döden. Men kyrkogården väckte också andra funderingar. Gravplatsen kunde med tiden ha gått från att vara meningsbärande till att bli en börda. Det fanns andra sätt att minnas de döda, menade de intervjuade. Kyrkogården kunde även vara en plats som symboliserade starka och obehagliga minnen och därför undveks. Äldreboende och sjukhus utgjorde de platser där döendet och döden blev konkret - själva sinnebilden för beroende, ett utdraget döende och lidande, och där tankar på det egna döendet och döden medvetandegjordes och där andras döende blev som allra mest påtagliga. Det var på äldreboende och sjukhus som man då och då såg slutet på långvariga sociala relationer och det var där man tog farväl av de döende, men det var också en plats där man själv helst ville slippa avsluta sina dagar. Hemmet utgjorde den personliga plats där minnen av de döda kunde uppstå. Det var inte ovanligt att föremål, accessoarer och kläder som tillhört någon anhörig och som sparats ledde till funderingar på livet som varit och på döden. Det var saker som på något vis hjälpte till att bevara minnet av en person. Föremålen i hemmet kunde också vara förknippade med förlusten av viktiga relationer, men även med förlusten av en gemensam biografi - förlusten av en gemensam nutid såväl som förlusten av ett gemensamt förflutet och en förlorad framtid. Även nekrologerna och dödsannonserna i dagstidningarna som lästes vid köksbordet gav upphov till funderingar på döden. Naturen väckte även den tankar om liv, döende och död, men det handlade om en annan slags förgänglighet. Det var inte direkt tankar på den egna döden eller andras död som framkallades utan i stället funderingar om världsalltet och att vara en del av det. Media framkallade också funderingar på döden. Där handlade det ofta om främmande människors död och om döden i ett vidare existentiellt perspektiv, som engagerade ibland men som inte nödvändigtvis ledde till en mer medvetenhet om den egna döden.

$P a ̊$ vilka sätt hanterade de intervjuade sina funderingar på döende och död? Ett antal mönster framkom i analysen och handlade om att hantera döende och död både i tankarna och praktiskt. Det handlade om att "medvetet utforma - svar" genom att fatta viktiga beslut, överväga för och emot för att uppnå kontroll och även en känsla av trygghet. Ett par av mönstren handlade mer om att ha en tankemässig kontroll över de egna funderingarna på döende och död. Ett resonemang handlade om att som äldre och gammal så var man "on time" för att dö. Samtidigt gällde det inte dem själva - de ansåg sig på något vis tillhöra undantaget. I detta hanterade av döden ingick även förhoppningar om att döden skulle ske snabbt, att slippa det långsamma döendet. Man tänkte även på själva dödsögon- 
blicket och kände rädsla inför att kanske dö ensam. Andra mönster gällde i större utsträckning praktiska överväganden - att exempelvis "dödsstäda", det vill säga det skulle vara ordning på saker och ting ifall dödsfallet inträffade under natten. Att planera inför den egna begravningen eller att inte göra det var också sätt att hantera funderingarna på döden. Några planerade grundligt inför den egna begravningen, eftersom de ansåg det nödvändigt att förmedla sina önskemål inför döden. Andra planerade inte alls. De ansåg det onödigt, komplicerat eller alldeles för tidigt $\mathrm{i}$ livet, de var ju inte allvarligt sjuk och döende.

I detta kapitel diskuterade jag alltså de intervjuades funderingar och tankar på döende och död. I nästa kapitel 6 fokuserar jag i stället huruvida de intervjuade samtalade med någon eller några om döende och död. 


\title{
KAPITEL 6
}

\section{Samtal om döende och död}

\begin{abstract}
Arne, 86 år, lägger nya vedklampar i kökskaminen och det soliga vinterlandskapet kan knappt skönjas utanför det igenimmade köksfönstret, han förbannar februarisnön som bara ställer till förtret, sätter sig vid bordet igen och tar upp tråden i vårt samtal - döden. Han konstaterar att det kanske snart är dags att ta upp det här med döden med sin dotter, bestämma gravplats, antingen familjegraven i Stockholm eller kanske på kyrkogården i samhället där han bor, men då måste han ju ordna med en gravplats - "Då måste jag ju se till att bli fastighetsägare då och köpa en kvadratmeter, så att man kan ha som egen mark", säger han skrattandes. Arne kommer även in på kistor och nämner att det får bli den billigaste varianten, det måste han berätta för sin dotter, men han är tveksam till när han ska ta upp detta med henne. Det får bli vid "något sådant här lättare sammanhang, om det nu kan vara lättsamt", säger han. Därefter konstaterar han att blir det inget samtal med dottern så får hon göra som hon vill: "det är ju ingen katastrof på något sätt...".
\end{abstract}

I det här kapitlet diskuterar jag huruvida de intervjuade samtalade med andra människor om döende och död. Frågan är då varför de intervjuade skulle vilja prata och diskutera om döende och död med andra människor när dessa ämnen anses väcka känslor, oro och ångest (Vestlund, 2008, s. 7). Tidigare forskning är dock motsägelsefull och ger en komplex bild av den betydelse som samtal om döden kan ha. Arne, som omnämndes ovan, gjorde inte någon hemlighet av att han nästan aldrig funderade på döden eller för den delen samtalade med någon om döden. Ibland pockade dock döden på uppmärksamhet och då handlade det om vad han borde säga till dottern. Arne ansåg att det var problematiskt - om han så skulle vilja - att i vardagslivet få tillfälle att tala med dottern om det som rörde hans död. Om en möjlighet till samtal aldrig skulle yppa sig, ansåg han att det hellre fick vara.

Arne var inte ensam om att tycka att det var komplicerat att få till stånd samtal med familj och vänner för att kunna berätta om sina funderingar kring döden. Några intervjuade framhöll att det vore värdefullt, inte minst nu på äldre dagar, att då och då kunna prata med någon om döden. Vissa menade däremot att de inte alls upplevde samtal om döden som besvärande. Det var ett helt naturligt samtalsämne. Det gällde emellertid inte alla intervjuade. Några framhöll att de knappast pratade med 
någon om döden, och menade att de inte hade behov av det heller. Det var något som valdes bort helt enkelt: "Men det är ju inget man sitter och snackar om på en trevlig middag med vännerna så ofta, det väljer man väl bort även om det förekommer det också". För andra var döden ett ämne som sällan upptog deras liv och tankar, och det var inte förrän vid intervjutillfället som de började fundera på, eller blev påminda om, denna fråga och i vad mån de pratade med någon om döden. Oavsett om tillfälle gavs eller inte ansåg några att döden var svår att prata om: "Det känns ju jättesvårt, det här, också att sitta och prata med dig nu här."

Det här kapitlet fokuserar forskningsfrågan: Vilka erfarenheter har äldre människor av möten med döende och död i det vardagliga livet, speciellt av samtal med andra människor om dessa frågor? Kapitlet har en tematisk disposition och är uppbyggt utifrån följande rubriker som knyter an till teman som framkom i analysen och som går att sammanfatta som: familjekretsen - vänkretsen - föreningslivet. De frågor jag diskuterar är: Vilka erfarenheter har de intervjuade av att prata med någon om döden i vardagen? I vilka sammanhang skedde det? Vad var det om döden som avhandlades och hur reagerade omgivningen på denna typ av samtal? Var det viktigt att samtala om döden? Kapitlet inleds med en diskussion om det som kan kallas samtalets paradigm.

\section{Samtalets paradigm}

Flera forskare, däribland Fischler, anser att vi i dag lever i en tid som karaktäriseras av "samtalets paradigm" - man menar att samtal och öppenhet är viktigt (avgörande) för att mildra upplevelserna av svåra livserfarenheter. Det är genom att visa känslor, prata och bearbeta svåra upplevelser och framför allt genom att söka professionell hjälp som människan kan mildra depressioner, ohälsa, etcetera. Det finns en tanke "att man måste få ur sig någonting, tanken att det jag inte säger, det jag lämnar kvar inne i mig, det växer sig väldigt stort och tär mig och det kan dessutom leda till att jag får hälsoproblem" (Fischler, 2008) ${ }^{11}$. Fischler menar att vi i Sverige har en tradition av att traumatiska upplevelser och känsliga ämnen måste bearbetas, och att denna uppfattning har sin grund i psykiatrin, och då framförallt $\mathrm{i}$ kölvattnet av Cullbergs bok Kris och utveckling (1975) (Fischler, DN 130820) ${ }^{12}$. Fischler anser dock att öppenhet och samtal kring svåra ämnen inte alltid är rätt väg: "Ett missförstånd är att alla behöver prata /.../ en föreställning om att samtal är lösningen på alla psykiska svårigheter". Dessutom finns det inte, menar hon, några empiriska stöd för

\footnotetext{
${ }^{11}$ (SR P1, 2008).

${ }^{12}$ (SR P1 2008; DN 130820).
} 
att samtal alltid är lösningen (Fischler, DN 13082013, se även Wortman \& Boerner, 2006; jfr Dahlberg \& Hassling, 2012; Stroebe \& Schut, 1999). I en engelsk kontext pågår delvis en annan debatt med anknytning till samtal. Det är en valfrihetsdebatt kring döden, som också betonar samtalets betydelse men i en annan mening: människan bör förbereda sig inför sitt eget döende och sin egen död, genom att planera inför döden, informera anhöriga om sina val och samtala med närstående, etcetera (Walter, 2013). Resonemanget illustrerar två olika sidor av samtalets paradigm - en instrumentell aspekt och en mer "terapeutiskt" inriktad aspekt.

I kontrast till detta problematiserande antagande om ett samtalets centrala betydelse, menar flera forskare i stället - däribland von Malmborg och Silfving (2007) och Nilsson (2008) - att avsaknaden av en öppenhet ifråga om döden är stor. Det som snarare behövs är ett slags paradigmskifte: "Om vi talar om döden, om vi förbereder den, om vi fyller den med mening, då bygger vi en ny tradition som hela samhället behöver" (Nilsson, 2008, s. 13). Att prata och att vara öppen kring svåra ämnen tycks rent generellt vara av central betydelse för alla människor och inte minst bland äldre människor. Om inte äldre människor ens funderar och än mindre pratar om döden, kommer äldre att bli lämnade ensamma att ta itu med sin rädsla och oro inför döden (Howarth, 1998, s. 686f).

Flera forskare menar att samtal om döden ofta är förknippat med obehag, ibland snudd på tabu.

Det tabu som anses omgärda samtalet om döden och döendet kan möjligen ha sin förklaring $\mathrm{i}$ att döden och efter döden är ogripbart i likhet med Baumans sätt att uttrycka sig (Rahm Hallberg, 2010, s. 89).

Ågren Bolmsjö nämner att det kan finnas flera skäl till varför det kan vara svårt att prata om döden:

Ett hinder kan vara själva språket, orden räcker inte till för att beskriva insikter och erfarenheter som rör den existentiella sfären. Det känns fattigt när man ska försöka beskriva något så stort, allvarligt och mäktigt som döden. En annan begränsning kan vara att samtal av det här slaget kräver förtroende och tillit och det skapas inte automatiskt. Det krävs tid och stillhet för att öppna upp för samtal om döden. Och kanske har vi $i$ vår tid svårt att ge oss hän i något som tar tid. En tredje orsak är säkert det motstånd som rädslan inför döden ger. Det som man är rädd för undviker man, vad det än är (Ågren Bolmsjö, 2006, s. 73).

\footnotetext{
${ }^{13}$ (SR P1 2008; DN 130820).
} 
Rahm Hallberg menar att ett sätt att ta sig igenom denna barriär är att prata om önskemål inför döden:

Det i sin tur kräver att personen får tillfälle att tala om sitt liv, summera och reflektera över det som varit och det som är. I det ingår också att förhålla sig till den egna döden. /.../ En annan aspekt av att närma sig döendet och döden är att få tala om sina önskemål och farhågor inför döden (Rahm Hallberg, 2010, s. 99)

Med utgångspunkt i diskussionen huruvida öppenhet och samtal kan vara ett sätt att mildra mötet med svåra ämnen som döende och död eller om så inte är fallet - finns det anledning att utforska vilka erfarenheter de intervjuade har av att prata om döden $i$ vardagen med någon, samt vilken betydelse de tillskriver samtal om döden? Följande tre sociala miljöer fokuseras - familjekretsen - den nära vänkretsen - föreningslivet. Tre sociala sammanhang som flertalet intervjuade hade tillgång till, kände tillhörighet med och som de också betonade var betydelsefulla för deras vardag och framtid och för deras möjligheter/hinder till samtal.

\section{Familjekretsen}

Några intervjuade ansåg att det var problematiskt att prata om döende och död med sin livspartner, sina barn, barnbarn och andra nära anhöriga. De menade att deras funderingar kring döende och död oftast fick stanna vid tankar, därför att de inte ville stöta sig med eller göra sin omgivning orolig genom att ta upp dessa spörsmål. Någon sade:

Jag tror, när du frågar, jag måste tänka efter, så tror jag faktiskt att det är det jag fick med mig hemifrån [att inte prata om döden], att det gjorde man inte. Det var något oundvikligt, det var inget man skulle grubbla över. Man skulle inte gräva ner sig, man skulle behärska sig, man skulle, ja, det var det här kärvare...

För andra kunde emellertid samtal om döende och död genomföras obehindrat med de allra närmaste. En intervjuad sade: "Det har vi nog alltid varit ganska öppna mot varandra om, det har inte varit något hysch-hysch där inte, utan det går bra". Cicirelli argumenterar utifrån sin studie att familjen har ett betydande inflytande på äldres attityder till döden: 
The present study indicated that family is a far more important influence on the death views of older adults than previously expected, especially such family members as siblings, adult children, and grandchildren. However, there are few if any studies relating the influence of family members to elders' personal meaning of death, death fears, and views of the dying process (Cicirelli, 2006, 353).

Även Rahm Hallberg framhåller detta inflytande och vikten av samtal:

\begin{abstract}
Samtalet om döden och efter döden ska rimligen också äga rum inom den egna familjen så att familjemedlemmar är insatta i den äldres önskemål och därigenom kan förbereda sig själva på den period som ska komma och omhändertagandet av den äldre och dennes tillhörigheter efter döden. /.../ De kan tillsammans behöva tala igenom sin syn på sista levnadsfasen, begravningen och gravplats så att de närstående kan hjälpa till att uppfylla den äldres önskemål (Rahm Hallberg, 2010, s. 98, 100).
\end{abstract}

Den fråga jag fokuserar i följande avsnitt är: Vilka erfarenheter har de intervjuade av att $\mathrm{i}$ vardagen prata med någon nära anhörig om döden? I analysarbetet framkom två mönster. Det ena mönstret handlade om att döden då och då kunde var ett ämne att förhålla sig till i möten och samtal med nära anhöriga i vardagen - genealogin leder in på döden - den egna döden lyfts fram - tillsammans med barnbarnen bryts tystnaden. Det andra mönstret handlade om att döden sällan var ett tema som förekom i samtalen med nära anhöriga i vardagen - att undvika döden - ett svårpratat ämne.

\title{
Genealogin leder in på döden
}

Några intervjuade hade under senare tid börjat fundera över att de faktiskt tillhörde den generation som stod näst i tur att dö. Kort sagt, de menade att som far- och morföräldrar utgjorde de den länk i genealogin mellan avlidna förfäder och framtidens generationer, en länk som snart skulle brytas. Någon sade: "Generationer kommer och generationer går, det är liksom det som är meningen med det hela, så att säga, så ser jag väl på det". En av deltagarna mindes så väl när det uppdagades för henne att hon utgjorde denna länk:

Jag vet att när mamma dog så, det kommer jag ihåg, att när jag satt i kyrkan, jag fick ett sådant där riktigt gråtanfall för jag upptäckte plötsligt, nu är jag äldst i släkten, eller en av de äldsta i släkten, nu finns det ingen mer.

När barnbarnsbarnen sedan föddes blev det ytterligare en bekräftelse på att livet började närma sig slutet: "Men det är alltså fyra generationer 
$[\mathrm{nu}]^{\prime \prime}$.

Detta faktum, att räknas till generationen närmast i ordningen att dö innebar också att vissa åligganden borde hinnas med innan tiden bokstavligen skulle ta slut. I och med att några av de intervjuade hade upplevt att de aldrig haft tid att fråga sina föräldrar speciellt mycket om deras liv innan de dog - "man skulle ha frågat dem om saker och ting" - så ville de inte låta sina egna barn och barnbarn leva i ovisshet om hur livet hade gestaltat sig. Andra däremot berättade att såväl deras föräldrar som faroch morföräldrar hade varit måna om att få "berätta om saker och ting". En plikt som framhölls var vikten av att på något vis kunna förmedla sin livshistoria innan det var för sent. Några barn och barnbarn hade dessutom redan börjat efterfråga någon slags självbiografisk berättelse. Bertil, 84 år, berättade att hans systerdöttrar hade gett honom bok och penna med följande order: "Här ska du skriva ner allt, vad du har talat och berättat om och så där". Några intervjuade hade alltså börjat nedteckna sina minnen, sortera fotografier, andra hade redan tidigare i livet börjat skriva dagbok så att barn och barnbarn skulle få vetskap om deras förflutna innan det var för sent.

I takt med att nya generationer föddes, och gamla generationer dog, hade de intervjuade börjat fundera på döden. Att då få förmedla sin livshistoria eller att symboliskt få räcka över ett släktträd till kommande generationer tycktes fungera som en slags markering eller en påminnelse om att livet inte varar för evigt (jfr kapitel 7). Döden var kanske snart i antågande och då fanns det inte längre så många möjligheter kvar att få berätta. Då var detta ett tillfälle som samtidigt kunde öppna upp för existentiella frågor.

\section{Den egna döden i fokus}

Nora, 76 år, berättade om en begravning som nyligen hade ägt rum och som hade fått henne och maken att så smått börja prata om framtiden och om döden:

Ja, det är klart att nu har ju jag och min make pratat en del, det blev ju aktuellt i och med hans kusin som vi hade begravning för, eller jordfästning heter det väl, i augusti. Då blev det ju också att man talar om döden, vi är väl båda, tror jag, åtminstone jag, lite kluvna till det här med sarkofag, att stå för all framtid, ja, man blir kluven, men annars så, jag vet inte riktigt...

En närståendes dödsfall kunde alltså få de intervjuade att börja prata om den egna döden. Funderingar om livets slut och vilka planer och önskemål som man hade gått och burit på kunde bli till samtalsämnen med livspartnern, barnen eller barnbarnen. Några intervjuade hade oförblom- 
merat redogjort för sina planer inför livets slut medan det för vissa däremot tycktes vara en mer utdragen process. Carl, 71 år, som sade att han då och då funderade på döden (se kapitel 5), berättade att både han och hans fru upplevde det som svårt att ta itu med sina önskemål. Det var någonting de "skjutit framför" sig och de ansåg att "tyvärr, det är jättedåligt, för det borde vi ju göra". Carl sade dock att de så sakteliga hade börjat formulera några önskemål, även om det hade bjudit emot:

Men personligen så har jag ju inte, jag menar vi har ju pratat väldigt lite om det här över huvud taget med varandra. Jag har väl ändå antytt utan att vi har suttit ned och pratat så där allvarligt. Så i förbigående om vi har nuddat vid det, så har jag väl kanske sagt då att jag vill ju gärna bli kremerad och ligga i minneslund eller något sådant.

Några intervjupersoner upplevde det emellertid som en skyldighet och ett ansvar att deras anhöriga fick veta hur de ville ha det i livets slut. Det handlade, med andra ord, om en vägledning eller en gemensam planering av den sista föreställningen. Denna känsla av ansvar som kom till uttryck ligger i linje med Walters (2013) argumentation, där han hävdar att vår tid präglas av "the theory of choice". Det innebär att människan förväntas ta ansvar för sitt eget döende och sin egen död, genom att planera inför döden, informera anhöriga om sina val, samtala med närstående om dessa frågor. En utsaga handlade alltså om vikten av att kunna förmedla till släktingar hur man ville ha det i livets slut:

Vi har många gånger talat om för ungarna vad de ska göra med oss när vi dör. De vet precis vad de ska göra.

Men det här med minnesstund, vilka psalmer, ska det vara borgerlig begravning eller inte, det kan jag förmedla till mina döttrar ändå, utan att det bokförs så att säga.

I dessa fall hade de intervjuade låtit (eller skulle) förmedla sina önskemål antingen muntligt eller låtit anhöriga ta del av exempelvis det ifyllda Vita Arkivet. De ansåg att detta var en lämplig tidpunkt i livet att låta funderingar och reflexioner angående döende och död bli konkretiserade i samtalen med livspartnern, barnen eller barnbarnen. Samtalen med anhöriga om önskemålen inför döden fick dem ofta att känna sig lugna efteråt: "Jag tycker att det har känts så lugnande att vi faktiskt bestämt oss".

De här personerna ansåg att det var viktigt att kunna samtala om den egna döden, och samtidigt vägleda sina anhöriga gällande önskemål inför livets slut. 


\section{Tillsammans med barnbarnen bryts tystnaden}

Ett par intervjuade framhöll att ett sätt att närma sig ämnet döden var att vända sig till barnbarnen. De upplevde det ibland som alltför känsligt att samtala om döende och död med livspartnern eller med barnen. Att då vända sig till barnbarnen blev på något vis som att avdramatisera döden. Visserligen ställdes saker och ting på sin spets då barnbarnen genom sin frågvishet många gånger bröt igenom en svårgenomtränglig barriär, men det var ändå just tillsammans med barnbarnen som de existentiella frågorna och svaren gjordes möjliga. Det kunde exempelvis handla om att man pratade med barnbarnen om vad som hände efter döden:

Asta, 77 år, berättar att när hennes barnbarn frågar var deras döde morfar och farfar är, så går vi ut på trappan varje kväll och så tittar vi - Däruppe är morfar och den stjärnan är farfar! och så vinkar vi. Så de förstår att när man säger att de är döda då är de i himlen /.../. Men annars pratar vi aldrig om något sådant där...".

Ett annat sätt att närma sig döden och samtidigt visa anhöriga hur de ville ha det på begravningen eller efter döden var att förmedla detta på ett mera praktiskt vis. För Celia, 86 år, hade det blivit en tradition att varje höst samla barn och barnbarn och tillsammans göra gravpynt i hemmet för att därefter gå till kyrkogården och gravsmycka. Därigenom fick hon ett tillfälle att samtala med nära anhöriga om sina önskemål.

Några intervjuade menade att det var tillsammans med barnbarnen som tystnaden kring döden bröts. Det kunde handla om existentiella funderingar som kom till uttryck, men också praktikaliteter runt gravsmyckning. Det var i dessa sammanhang som anhöriga kunde få vägledning om deras önskemål vid livets slut - ett ansvar som även inkluderade barnbarnen i samtalet om döden.

\section{Att undvika döden}

I kontrast till förhållningssättet ovan, att vara öppen med döden inom familjekretsen, framhöll i stället några deltagare att samtal om döende och död borde undvikas i umgänget med livspartnern, barnen och barnbarnen. Andra konstaterade att de "inte tycker att det [döden] är mycket att prata om egentligen" med nära och kära - "vi lever och sedan kommer det att stängas av" och döden behövde därför inte ältas. En annan menade: "Men det är väl mest en inre monolog, naturligtvis, det är det. Det är inget så här som vi pratar ständigt om, det är det ju inte". De såg alltså inte någon större mening i att konkretisera sina funderingar på döden inför de anhöriga. I stället tycktes ansvaret helt sonika ha lämnats över till dem: 
Ja, det finns ju de som gör upp så där, om allt, hur de vill ha sin begravning, vem som ska sjunga och sådana där saker. Nej, det överlåter jag till mina efterlevande. Jag vill inte sitta här och skriva någonting om att de och de och den psalmen ska vi ha, och den vill jag ha som ska sjunga, nej. Ingenting sådant.

Nej, nej, det har jag inte gjort, det får väl de andra göra...

Ett par deltagare gjorde också gällande att de anade eller snarare förutsåg vilka preferenser och ståndpunkter deras anhöriga hade om döden och ansåg det därför meningslöst att samtala om döden: "Nej, det gör vi faktiskt inte [pratar om döden]. Jag inbillar mig att hon tror ungefär som jag att man dör och sedan [är det slut]". Andra antydde dessutom att det var de anhöriga som inte ville ta upp temat döden eller prata om den:

Sedan tycker jag inte att jag ska belasta henne [dottern] med det och sätta igång sådant, hon är ganska känslig.

Jag går gärna till kyrkogården men jag har gått mycket ensam dit för barn och barnbarn de bryr sig ju inte om det där så väldigt mycket. Nej, det är för dem någonting långt bort. Precis som det var för mig när jag var ung.

Alla är så upptagna, de har inte tid /.../ barn vill inte att mamma ska gå bort. Det är bara jobbigt.

Det fanns alltså flera skäl till att inte föra den här typen av samtal inom familjekretsen. Isak, 75 år, som sade att han nästan aldrig funderade på döden och som också ifrågasatte det mänskliga i att grubbla på döden, nämnde:

Däremot mina barn är jag inte säker på att de skulle vilja, de vill slå bort frågan på något sätt. Deras upplevelser, när mamman dog, är starka kan jag säga.

Lena, 85 år, har liknande erfarenheter av att dottern inte vill prata om döden: "Min dotter slår ifrån sig [döden] helt och hållet", och det gäller framförallt faderns död: "Inte ville hon se hans dödsannons eller någonting sådant där. Det har hon fortfarande inte gjort, fast det är 19 år sedan". Dottern vill helst inte heller ta del av Lenas önskemål som är nedskrivna i det Vita Arkivet. Lena sammanfattar situationen: "Men jag förstår inte riktigt min dotter, men det är att vi är så otroligt tighta och har blivit mer och mer så att jag förstår att den dagen [då Lena dör] inte blir lätt för henne men hon måste ju programmera sig på något sätt för det kommer ju." 
För de här intervjupersonerna var det viktigt att undvika att prata om döden - döden skulle tonas ner - kanske för att på något vis skydda anhöriga och kanske också dem själva.

\section{Ett svårpratat ämne}

Att ha funderingar kring döende och död var en sak, att förmedla och sätta ord på tankarna var däremot inte självklart. Döden var komplicerad. I stället undvek några att beröra de här frågorna med sin livspartner, barn och barnbarn, på grund av de känslor som samtalen kunde framkalla. De ansåg att döden egentligen inte var något vidare samtalsämne: "Inte så där direkt, det har väl aldrig varit, inte precis att kalla hit dem och säga: Nu ska vi prata om det här". Inga, 91 år, berättade att hon hade bjudit sina barn på lunch för att föra döden på tal och "introducera dem i det här nämligen", men att det hela minst sagt hade runnit ut i sanden:

Det var någon speciell dag, då jag bjöd dem på någon lunch på Djurgården och jag sa att nu ska vi sätta oss ner och prata om det här. Hur det ska bli och så där. Men, du vet, det blev i alla fall inte, ja det uppskattade de allihop [lunchen] men det var ju inte så där att de gick hem och fick någonting med sig [av döden]...

En intervjuad sade: "Men jag har aldrig frågat dem om de är rädda för döden eller så", och varje gång en diskussion tog sin början med barn och barnbarn om vem som skulle ärva vad av hemmets föremål, så möttes hon inte sällan av ett: "Nej, du ska inte prata sådär mamma". Någon sade sig också vara lite förundrad över varför han inte hade tagit upp det här om döden med sina barn: "Nej, jag har inte fört sådana samtal, när du påpekar det så tycker jag det är konstigt att jag inte har gjort det men så är det". Också det omvända resonemanget förekom - varför frågade inte barnen dem om deras förhållningssätt till döden: "Men inte det där hur jag känner eller om jag är rädd för döden eller om jag är orolig och så vidare, nej, inte så att man sätter sig ner och talar. Nej, det är märkligt". Anledningen till dessa förhållningssätt tycktes ibland helt enkelt handla om att inte störa den goda relationen till sin livspartner, barn och barnbarn.

Att döden ansågs vara svår att prata om fick också andra konsekvenser. Några hade varken planerat eller förberett någonting inför den egna begravningen, och hade inte heller underrättat sin livspartner eller sina barn: "Vi har inte anordnat på något sätt hur själva begravningen skulle gå till" och "så långt har vi inte kommit". En paradox i sammanhanget var att de här personerna ofta $i$ intervjuerna underströk att det hade underlättat om deras föräldrar hade uppgivit sina önskemål inför döden. Samtidigt ville de själva inte vägleda de egna barnen genom att tala om hur de 
ville ha det vid livets slut. Vid resonemang kring detta kom de bland annat fram till att de hade uppfostrats till att inte prata om döden med sina släktingar. "Men jag vet inte om det är min generation /.../ att vi har svårt för det här, att vi är fostrade [så]", menade någon av deltagarna. Nora, 76 år, som då och då pratade om döden med sin make, framhöll:

Jag har en kusin nu på mammas sida, hon är två år yngre än mig och vi konstaterade här att vi är ju uppfostrade, uppväxta med - hennes mamma, föräldrar var också äldre - det blev ju så på den tiden. Vi är ju uppfostrade som de var uppfostrade och det var sena 1800-talet, så det var helt andra normer, värderingar. De tog till sig det nya men grunden var ju, och det är möjligt att jag där fick med mig, det här att liksom ta det som det kommer och inte oroas för mycket framåt och acceptera och ja, jag vet inte...

Föräldrarnas syn på döden levde kvar hos de intervjuade och hade präglat deras förhållningssätt till döden, och denna syn på döden fick i sin tur också konsekvenser för de egna barnen och barnbarnen:

På något sätt så är ju döden undangömd, man får inte vara med, eller unga människor och barn får inte vara med vid döendet och döden. Man kan leva säkert väldigt länge utan att ha varit med om att ha sett en död människa. På något sätt så har man ju en känsla av att man har varit rädd för döden, inte velat utsätta barn och så för döden.

Rädslan för att förlora den goda relationen till livspartner, barn och barnbarn var ett starkt vägande skäl till att inte vilja samtala om döden inom familjekretsen. Men det verkade ändå finnas en önskan om att någon gång kunna samtala med en närstående om de här frågorna. Oftast tycktes det dock stanna vid en tanke.

\section{Vänkretsen}

Några intervjupersoner berättade att de emellanåt kände behov av att få samtala med de närmaste vännerna om döende och död, men att de ibland upplevde att det var svårt. Någon sade: "Nej, nej det gör man inte. Det gör man inte [pratar om döden]". Detta trots att många av vännerna var jämngamla, det vill säga, de hade levt ett långt liv tillsammans och de hade gemensamma erfarenheter. Just därför ville man inte lasta vännerna med samtal om döden. Då och då utmanade de intervjuade sig själva och lät vännerna ta del av de egna tankarna. Andra gånger kom man bara in på samtalsämnet utan några förberedelser och samtalen flöt på: 
Det har [vi] vid något tillfälle glidit in på de här frågorna [om döden] också faktiskt. I och med att vi är i någorlunda samma ålder så är det klart aktuellt för oss, så att säga, att ha uppfattningar eller hur man ska säga.

Det var inte heller ovanligt att vänner vände sig till intervjupersonerna för att få prata om döden. Några av dem konstaterade däremot att de aldrig eller nästan aldrig vände sig till vännerna, de hade varken anledning eller kände behov av det. Någon sade: "Jag har inte känt det där behovet så väldigt mycket".

Den fråga som jag fokuserar i följande avsnitt är: Vilka erfarenheter har de intervjuade av att prata med vännerna om döden? I analysarbetet framkom två mönster. Det första mönstret handlade om att döden faktiskt var ett ämne som man emellanåt pratade om i vänkretsen - vi tangerar ämnet döden - förtroende och gemensamma erfarenheter. Det andra mönstret var motsatt: döden hörde inte hemma i samtalen inom vänkretsen - ett olämpligt samtalsämne - ett ämne som väcker rädsla.

\section{Vi tangerar ämnet döden}

Ett mönster i berättelserna handlade om när vännerna i den närmaste bekantskapskretsen började bli skröpliga och sjuka eller avled. Vid sådana tillfällen blev även intervjupersonernas funderingar på döende och död mer påtagliga (jfr kapitel 5). Tankar som rörde döden i största allmänhet men framförallt vännernas död och den egna döden aktualiserades. Doris, 78 år, men även Isak, 75 år, som ifrågasatte poängen med att ägna sig åt att fundera på döden, menade ändå:

Men att man tänker ju - då går den bort och så går den bort, när går nästa bort och hu så hemskt, då har man inga kvar och så där kan jag nog ... tänka.

Att det är signaler om - ingen går fri utan det kommer dagar då man själva är på väg.

Umgängeskretsen utgjordes till övervägande del av äldre och gamla människor, vilka de intervjuade inte sällan hade åldrats tillsammans med. $\mathrm{Nu}$ hade de börjat falla ifrån en efter en. Några konstaterade: "Så duggar ju begravningarna ganska tätt nu för tiden, eller tätt, men det har ju varit äldre människor då...", och "det märker jag ju på att många av dem dör och försvinner, vilket är en stor olycka, dels för dem men också för mig. Man är vän med och har varit vän med och så tunnas ju, så att säga, nätet ut och det är väldigt svårt ...". Detta var dock ett faktum de på något vis 
måste acceptera i den ålder de befann sig i "att döden gallrade bland ens vänner", enligt några av de intervjuade:

Men det är ju ganska typiskt i den här åldern alltså att nätverket kring alltså glesnar ut så att säga. Det är riktigt påtagligt nu, kan man säga. Efter 80 års ålder så har man inte alls kvar så många vänner, som man har haft tidigare alltså.

Ett par deltagare nämnde att vid träffarna med vännerna väcktes ibland tanken på vem i vänkretsen som nu stod på tur att dö: "Så tänker man kanske - ja när är det min tur". Det föreföll som de vid dessa sammankomster emellanåt och tyst för sig själva gjorde bedömningar, läste av och bildade sig en uppfattning om vännernas hälsotillstånd - "Livet blir lite begränsat för några av dem" och några hade "dragit sig undan på något sätt". Vännerna berättade inte spontant om sina krämpor och de intervjuade valde att inte fråga dem om hälsan. De "noterade" och bedömde med hjälp av sina sinnen vännernas välbefinnande. De lyssnade efter tonfall, avläste kroppspråk eller enbart betraktade dem. Carl, 71 år, sade:

Det är klart, vi har några som i varje fall är 77 nu och det är klart då märker man ju att det kommer krämpor. Man ser ju att de är tröttare och att de inte orkar med på samma sätt som tidigare. Att allting går långsammare på något sätt och sådant där. Det märker man kanske inte riktigt på sig själv på samma sätt men det är klart på dem ser man ju det.

Därefter kunde några av de intervjuade ibland ställa diagnos rörande vännens hälsa och ta mod till sig att fråga om hälsan och också försöka "ge de här gamla kompisarna ett stöd så att säga och se till att vi inte slutar umgås". Just att samtala om hälsan och dess effekter kunde inte sällan leda in på samtal om döden: "Sådana där saker [hälsan och döden] som dyker upp och som sagt i umgängeskretsen när man har nått den här åldern så är det ju väldigt många som dör eller är på väg att göra det”. Även döende och dödsfall bland vännerna väckte tankar och frågor som behövde ventileras. Någon av dem menade att det kanske var främst vid dessa tillfällen som de samtalade: "Det är ju först när det verkligen blir en sådan situation [någon är döende], då kan man ju prata mer obehindrat". Isak, 75 år, kommenterade:

Även kompisar har ju planerat in när begravningen ska äga rum och vad de ska äta vid minnesstunden och sådant. Det har jag definitivt inte gjort och det är väl ett uttryck för att jag inte känner [mig sjuk]. Men det är inte så ovanligt alltså, men det är också sådana som har drabbats av en svår sjukdom, som visste om att nu är det kört. 
När vännerna började bli skröpliga eller var döende ledde deras ohälsa och dödsfall ibland till funderingar i vänkretsen och man började prata om döden. De intervjuade månade om sina vänner och ville ge dem sitt stöd i svåra stunder, ett sätt var då att prata.

\section{Förtroende och gemensamma erfarenheter}

För några handlade mötena med vännerna ofta om en hårfin balansgång mellan att å ena sidan leda in samtalen på döden och att å andra sidan försöka undvika att samtala kring döende och död. Jens, 72 år, påpekade att han ibland samtalade om döden med vännerna:

Det är klart alltså, när vi pratas vid så pratar man ju lite om sjukdomar och så här. Det är ju ändå en del i tillvaron numera. /.../ Många, många, jag vet inte, men alltså det är alldeles uppenbart att om man tangerar det [döden] så blir vissa ångestfulla och så. Det har jag nog upplevt. Att då sätter det igång en spiral hos den där människan som kan vara jobbig och svår. Men för vissa är det ju ett ämne man kan tala om, så det varierar. Människor kan ha olika distans till det här oundvikliga, så är det väl. Man får ta hänsyn till det när man pratar med folk. Visar de tecken på att de stegrar sig för ett sådant samtalsämne så får man ju byta samtalsämne. Det måste jag ju säga.

Mycket i denna balansgång var ofta avhängig situationen. Ett par aspekter i detta sammanhang var till exempel: vem av vännerna man samtalade med, i vilket tillstånd befann vännen sig $i$, vad som var lämpligt att samtala om vid sådana tillfällen, behövdes det alltid sägas någonting, och inte minst i vilket tillstånd befann sig intervjupersonen själv i. Med den många gånger långa vänskapen utvecklades ett förtroende dem emellan som gjorde det lättare att samtala om döden, ofta hade de livet igenom fått gemensamma erfarenheter av döende och död. Någon menade: "Det var flera stycken [bland vännerna], som mist sina män och en del miste sina fruar så det blev väl lite och prata kring". Gemensamma erfarenheter, förtroende men även att ha åldrats tillsammans gynnade avsevärt möjligheterna att samtala med de närmaste vännerna: "Ja, jag tycker väl det har blivit lättare med åldern". Ett par av deltagarna påpekade alltså att det hade blivit enklare att samtala om döden i dag än vad det var förr om åren: "Jaa, jag tycker det" och "ja, vi gör det - hon har berättat nu, nu har hon gjort sitt Vita Arkiv och hon har ordnat det och hon har ordnat det, men alltså hon har ordnat med det mer detaljerat än vad jag har gjort". Jenny, 85 år, som emellanåt funderade på döden och som också gjort vissa förberedelse inför den egna begravningen (se kapitel 5), berättade att hon tagit mod till sig: 
Det är klart att man ställer väl kanske inte frågan till en god vän, har du förberett dig? Men jag har frågat: - Har du skaffat Vita Arkivet? Det har jag sagt till rätt många. - Vadå, Vita Arkivet, vad är det? Och så har jag skickat det till dem. Jag vet vilket bekymmer det blir om de inte vet något, de efterlevande.

När någon av de närmaste vännerna hade dött var det inte ovanligt att de övriga vännerna samlades, utöver begravningstillfället, "kommer ihop några stycken" och pratade om vännen, minnen, livet och döden. Men samtalen tycktes också handla om att ingjuta hopp i kvarvarande vänner. Ett vanligt påstående var: "Så att det är så bra att en inte ger upp" och "vi försöker pigga upp dem som har haft det besvärligt".

Gemensamma erfarenheter, förtroende och en lång vänskap tillsammans var aspekter som deltagarna framhöll som viktiga för att de skulle kunna prata om döden med vännerna. Samtal av det här slaget krävde förtroende och tillit. För vissa tycktes denna tillit vara förknippad med tidigare minnen och erfarenheter av öppenhet kring döden (se kapitel 4).

\section{Ett olämpligt samtalsämne}

I kontrast till förhållningssättet ovan - att döden då och då var ett ämne som ventilerades $\mathrm{i}$ vänkretsen - menade några att döden skulle hållas i schack och i så stor utsträckning som möjligt hållas utanför de sociala sammahangen med vännerna. Döden borde enbart lyftas fram om någon var döende eller vid dödsfall, om ens då: "Ja, hon är så sjuk hon kanske dör snart, äsch, det pratar vi inte om." Döden skulle "vispas undan", "glömmas bort" eller så skulle man "inte låtsas om den". Några menade följaktligen att döden nästan inte under några villkor fick bli till ett samtalsämne i deras umgängeskretsar. En av de intervjuade, som ibland funderade på döden, men som inte lät döden bli till ett samtalsämne inom familjekretsen, påpekade:

Jag kan prata med folk och vi har kul ihop och så vidare men att lägga mig i andra människors bekymmer [döende och död] det skulle aldrig falla mig in. Det har jag inte med att göra. De får fixa sitt, jag fixar mitt.

En deltagare sade: "Det är sådant [döden] man håller för sig själv", eller som någon annan uttryckte det: "Men i övrigt så har vi inte talat om sådana här existentiella frågor utanför familjen". Det föreföll ibland vara så att var och en skulle sköta sig själv och sina förehavande och inte blanda in någon annan, mer än familjen nödvändigtvis. Döden var något som skulle hanteras på egen hand och det ansågs framförallt inte vara rätt samman- 
hang att göra det i kontakt med vänner: "Jag har aldrig haft något behov av att diskutera mina känslor med någon. /.../ Jag lever mitt liv och de andra får leva sitt". Andra påpekade: "Jag är rätt så klar över situationen. Jag tycker inte att jag behöver leta reda på någon som skall lyssna på mina tankar. Nej, jag tycker inte det. Jag är ju väldigt självständig" och:

Nej, jag går inte och delar de tankarna med någon annan inte, eller undrar hur de har det eller tänker på döden och så. Nej, det gör jag inte. Jag vet inte om jag är kall eller lustig på något sätt...

Döden var inte något de pratade med vännerna om, döden var något som man skulle hålla för sig själv eller inom familjen, det ansågs som ett olämpligt samtalsämne som det inte fanns något behov att prata om.

\section{Ett ämne som väcker rädsla}

Döden ansågs också vara ett ämne som väckte starka känslor och rädsla inom vänkretsen. Å ena sidan påpekade några intervjuade att det var vännerna som inte ville leda in samtalen på döende och död: "Nej, inte, det är dåligt med det här [syftar på vännerna i byn]" och "Nej aldrig! sa han, han skyggar så här. På något sätt talar man inte om det och det är otäckt och det är farligt och det är vad som helst". Jenny, 85 år, sade:

Låt oss säga att jag stämmer träff med några av mina kompisar, vi ska gå och fika eller göra någonting sådant där, då pratar man om så mycket annat. Sedan är det ju också så att en del människor skyggar, utan att de vet det så skyggar de för ett resonemang om döden. Det gör de faktiskt. Det har ju hänt att folk har sagt - Nej men Jenny, vi pratar inte om döda!" Nej, folk är lite rädda och lite så där.

En anledning som återkom var just att det kanske fanns en rädsla inför dessa samtal och därför bytte vännerna ofta samtalsämne när döden kom på tal: "Ja, jag upplever det så att man pratar inte om det, det är väl de reaktionerna när man berättar att så och så - snabbt pratar man om någonting annat". Ett annat skäl som fördes fram var åldern - om vännerna var äldre eller gamla ville de kanske heller inte prata om döden. Några menade: "Men inte i mina kretsar, för att jag är ju väldigt mycket med äldre människor nu för tiden" och "de gamla, de andra gamla, inte jag, vågar de prata om sådant med varandra tror du, det är så närliggande". De intervjuade trodde sig alltså ana att vännerna inte ville samtala - de kunde bli upprörda och man visste inte hur de skulle reagera. Många gånger tycktes de lägga skulden på sina vänner för oviljan till samtal. Doris, 78 år, som var änka och som då och då funderade på döden, sade: 
Mina bästa väninnor de har ju också blivit änkor då, men jag tror inte att de känner för det, jag vet inte hur jag ska förklara det. /.../ Men det är som de stötte på en mur. /.../ Nej inte [döden], nej, det är som om de ville gå förbi, kanske jag med vill, nej, jag vet inte...

Flera pekade också på svårigheten att närma sig en döende vän i avseende att prata om deras situation, några menade att trots att de var nära vänner, hade känt varandra länge och hade gemensamma erfarenheter så ansågs det problematiskt. Britt, 79 år, nämnde:

Jag har ju två kollegor, mycket nära vänner ... men de berör aldrig sin sjukdom [cancer] eller sin tillvaro ... ... och de är hemma, nej, ... även om jag försöker med någon mjuk inledning till någonting som härrör situationen, så det tas inte emot, det ska inte pratas, det är tråkigt. De skjuter det själva ifrån sig ...

Detta var alltså en situation som kunde upplevas som besvärlig då de intervjuade ville vara där för att kunna stödja och trösta, men de märkte att det ofta var förgäves. Några påpekade att det kunde bero på att cancersjukdomen och dess följder hade åsamkat förändringar i relationen med vännen. Ett annat skäl kunde vara att de kanske inte kände varandra tillräckligt väl för att prata om döden.

Å andra sidan hade de själva svårt eller vågade inte riktigt prata med vännerna om döden: "Men där är man ju lite avvaktande själv, jag vill ju inte pracka på min dödsångest på någon annan. "De tog det säkra före det osäkra och ville inte oroa sin omgivning. Några menade: "Det är obehagligt, då skjuter man ifrån sig det, kanske. Man vet kanske inte hur den andra reagerar. Vill inte uppröra, man avvaktar" och "man väljer att inte prata, man vill inte, man väljer inte, man är rädd för att störa, man pratar om glättiga saker, om vad man ska göra ...". Intervjupersonerna pratade inte heller om döden med döende vänner: "Döden, låt oss säga, mina vänner här som dog, vi pratade aldrig om något frånfälle, fastän de var så sjuka. Man pratar inte med de sjuka om döden precis, det verkar opassande". Ytterligare en person nämnde denna svårighet att prata med en döende:

Jag är ganska bestämd, jag tycker inte man vill pådyvla en människa den där typen av uppgifter. Den som är i något slags underläge, om inte de tar upp det själva så tycker jag man kanske inte ska göra det. Jag vet inte vilken nytta det är med det egentligen, tvärtom kan det vara till skada om man liksom börjar och prata. 
Det fanns flera skäl till att döden upplevdes som ett svårt ämne att tala om. Det ansågs obekvämt att samtala om döden med äldre och gamla människor när de själva kände sig äldre och gamla: "Ja, det är väl att en är rädd, en är gammal och prata att en snart ska dö" och "jag tror inte, vi håller inte på med sådant. Det är inte så, det är jobbigt helt enkelt. Det är ju så näraliggande när man blir gammal”. Några intervjupersoner ansåg alltså att vänkretsen inte var ett lämpligt sammanhang för samtal om döden - döden var ett ämne som väckte starka känslor och rädsla.

\section{Föreningslivet}

En överraskande aspekt av döden framkom i några berättelser. Det handlade om att deltagarna då och då använde sig av föreningslivet som plattform för att ventilera åsikter och frågor om ämnet döden. De gick då utanför den privata sfären av anhöriga och vänner. Varför vände man sig överhuvudtaget till föreningslivet, ett föreningsliv i vid bemärkelse - från en liten förening till Svenska kyrkan - med frågor om döden, vilka var motiven? Flera av de intervjuade menade att det inte var alldeles enkelt att veta vart man skulle kunna vända sig utanför kretsen av anhöriga och vänner, för att få möjlighet att prata om döende och död om man så skulle vilja. Fanns där överhuvudtaget något forum eller någon arena dit man kunde vända sig? Frida, 72 år, som var änka och som hade livserfarenhet av döende och död (se kapitel 4 och 5), förde ett resonemang om detta, som hon kallade en "lucka i samhället":

Jag kan känna nu att det vore bra att ha någon att prata med, ju äldre man blir. /.../ Så att det är klart att då tycker jag ju att det är en lucka i samhället men jag vet inte vem som ska fylla den. Om det handlar om det att man inte pratar med varandra om sådant här över huvud taget, eller jag vet inte riktigt vad det är jag behöver, men att det ändå finns något.

Frida menade att det väsentliga var, dels för egen del men även generellt, att komma ifrån det ensamma grubbleriet kring döden som inte alltid ansågs meningsfullt, att $\mathrm{i}$ stället kunna använda sig av något forum för att prata om dessa "allvarliga frågor".

Det var emellertid inte alltid oproblematiskt att prata om döende och död med personer som de träffade $i$ föreningslivet vare sig det gällde kristna församlingar, PRO eller Humanisterna med flera: "Normalt sett så pratar vi nog inte, vi som träffas i grupp, vi pratar ju aldrig om sådant, annat än om det är någon i kretsen som har dött. Då pratar de ju lite och så sjunger vi en psalm då för den som, men annars är det ytterst, ytterst sällan."

Den fråga jag fokuserar i följande avsnitt är: Vilka erfarenheter har de 
intervjuade av att prata med någon i föreningslivet? I analysarbetet framkom det två mönster. Det ena mönstret handlade om att döden var ett ämne som skulle hållas utanför föreningslivet - döden passar inte $i$ föreningslivet. Det andra mönstret handlade om att döden var ett tema som kunde tas upp i föreningssammanhang - att dryfta döden i föreningslivet.

\section{Döden passar inte i föreningslivet}

De flesta intervjuade var engagerade i föreningslivet och det var något som de också värdesatte högt. Det primära i dessa sammanhang var att känna gemenskap och tillhörighet, döden däremot var ett ämne som nästan aldrig omnämndes. Någon påpekade: "Jag blir ju inte påmind om döden i det vardagliga om jag går på ett föreningsmöte eller så" och någon sade även:

Jag är ju med, som sagt var, i PRO-föreningen hemma, och det är klart där är alla pensionärer, mer eller mindre gamla men det är sällan vi kommer in på direkt existentiella frågor.

Föreningslivet ansågs alltså inte utgöra någon arena för att ventilera funderingar och åsikter kring döende och död eller där känslor inför döden kunde visas. Det var också angeläget att försöka bli kvitt den skeva bild av att alla äldre människor bara pratade sjukdomar och död vid sina sammankomster. Kurt, 78 år, som ifrågasatte det mänskliga i att fundera på döden (se kapitel 5), förde ett resonemang om detta:

Man upplever ju pensionärer som att de bara sitter och pratar sjukdomar och död, jag tror inte det. Jag tror de är ganska kul när de kommer ut egentligen. De försöker att se bort från sina krämpor, och sjukdomar, ha en mera positiv syn på det. Kan hända att en och annan håller på och tycker det är kul att prata om läkare och recept och sådant där, men egentligen så tror jag att man söker kontakter för att komma ifrån den här typen av tankar. Och det här med döden det pratar man, vad jag förstår, absolut inte om. Så att nej ... ... jag tror egentligen att det är emot den mänskliga naturen att hålla på och fixera sig vid döendet.

Föreningslivet var alltså inte någon arena till för utbyte av tankar kring döende och död, snarare var det en arena för att just komma från grubblerier på döden.

\section{Att dryfta döden i föreningslivet}

Även om de intervjuade nästan aldrig pratade om döden i föreningssammanhang så kunde tankar på döende och död uppstå ibland då de var på 
något möte eller bevistade en tillställning. Detta tycktes dessutom bli vanligare ju äldre man blev: "Jag är med i en Rotaryklubb sedan länge och så stiger åldern där och då blir det ju många som faller ifrån emellanåt. Och då blir man ju påmind ...".

För andra var det däremot självklart att sätta ord på dessa sina funderingar kring döden. Det gällde i första hand i religiösa samanhang som vid besök i Missionskyrkan, Frälsningsarmén eller Svenska kyrkan. De hade vuxit upp i en kristen miljö och det upplevdes som självklart att vända sig till kyrkan för att få både ro och vägledning - "och så går vi hit bort till kyrkan då, det är inte så dumt det heller". Medmänniskorna i kyrkan hade ibland fungerat som stöttepelare vid tillfällen då de intervjuade hade behövt någon att prata med. En av dem som var knuten till en frikyrkoförsamling ansåg att:

Man kan absolut få hjälp och stöd av andra människor [i församlingen]. Och bli befriad ifrån oro och missuppfattningar, det tror jag säkert /.../ och chanserna [här] kanske är större att man kommer människor så nära så att man får sådana här relationer.

För flera intervjupersoner var det långt ifrån en självklarhet att påbörja samtal om döden med någon i föreningslivet. De ville ändå utmana och försöka få till stånd diskussioner om döden och då ansågs föreningslivets olika arenor vara lämpliga sammanhang. De bedömde även tidpunkten vara lämplig för att faktiskt samtala om den sista delen av livet just när man själv befann sig där. Hade de inte tidigare vågat samtala om döden under sitt aktiva föreningsliv så ansågs det vara aktuellt nu. "I dag är man mer öppen för saker och ting /.../ så den här spontaniteten, om man säger, den har nog kommit på äldre dagar, man har alltså blivit mer vuxen och mogen" och "för att i dag pratar vi verkligen om döden". Föreningslivet sågs som ett möjligt forum för samtal om döden, men det gick inte alltid så bra. Frida, 72 år, berättade om sitt initiativ och Nora, 76 år om sin tvekan inför dessa samtal med "främmande människor":

Förra året åkte jag, tokig kärring, på Humanisternas kurs en vecka. Tänkte om jag skulle gå in hos dem men jag passade inte där heller, så var det bra med det. Nej, nej det gick inte. /.../ Men det passade inte mig och de var redan färdiga med alla sina idéer. Jag ville ju prata om det [döden] och, ventilera och känna - vad tycker du och du - de lade fram hundra böcker som jag kunde läsa men nej. Men det finns kanske något annat, som jag inte har hittat än. 
Jag vet inte, nej jag behöver tid på mig innan jag kan prata. Jag har tänkt på det ibland när jag ser det här jag kallar det moderna sättet, stödgrupper och samtal med en gång efter en händelse och jag har tänkt - det hade aldrig fungerat för mig. Jag måste komma i fas...

Några av dem som på senare år hade närmat sig Svenska kyrkan, men även de mer vana kyrkobesökarna, menade att det var besvärligt att där få gehör för sina funderingar kring döden, trots att de ansåg kyrkan vara en lämplig plats. En liknande uppfattning var att de existentiella diskussionerna kring döden nästan helt lyste med sin frånvaro i kyrkliga sammanhang. Döden gjorde sig visserligen påmind ibland när någon, ofta äldre, församlingsmedlem hade avlidit. Vid dessa tillfällen brukade det samtalas lite om den avlidne och några psalmer sjöngs, men annars var det tämligen tyst kring teman som döende och död, förutom vid gudstjänsterna. De förväntade sig att döden någon gång skulle föras upp på dagordningen, utöver vid någons dödsfall, men de blev oftast besvikna. Varken prästen eller församlingsmedlemmarna tycktes vilja föra döden på tal. Frida, 72 år, förde ett resonemang om att prästen med sina erfarenheter kanske skulle kunna fylla detta upplevda tomrum: "Prästen förstås eller något sådant där - jag vet ju att jag vände mig också till kyrkan då i förtvivlan och det var ju inget, det, nej, det var inget. /.../ Så att nej, kyrkan har jag inte något vidare till övers för. /.../ I stället för kyrkan kanske, som vi inte längre har många av oss - men man har inte ersatt det med något annat". Någon menade att det var förvånande att det var så tyst i församlingen om döden: "Ja, de pratar kanske lite om döden, nej, nej, det gör vi inte" och det upplevdes som konstigt "för alla ska vi ju bort en gång". Asta, 77 år, pekade på att en orsak till denna ibland totala tystnad kanske var församlingsmedlemmarnas ålder: "Det är väl kanske mycket, vet du, många är äldre och de vill inte prata om det". Inga, 91 år, som också var aktiv i Svenska kyrkans föreningsverksamhet ansåg att det var ett ypperligt forum för att diskutera döden, men att så kanske inte alltid var fallet för de övriga föreningsdeltagarna:

Inte ens i de här kretsarna, i kyrkliga, de här kurserna. Nej, det måste jag säga. /.../ i den här livsegenskapskursen som jag går, vi skulle tala om olika saker som vi tyckte var intressanta, om vi har olika åsikter, vilka åsikter vi har och vad de är om, men just det här med döden är någonting som /.../ man talar inte om det och man säger inte: - Hur skulle du vilja dö? Har du någon önskan? Nej, jag tror att människor är rädda för att ge sig in på det, för jag tror inte människor vet. /.../ Det förekommer inte som något ämne man diskuterar. Vi kan ta upp det faktiskt på vår lista. /.../ Jag ska ta upp det här i vår livsegenskapskurs och höra vad de säger. 
En annan arena där några försökte ta upp frågor som knöt an till döden och äldres situation i samhället överhuvudtaget, var på PRO:s möten. Några av de intervjuade tog tillfället $\mathrm{i}$ akt och verkligen försökte föra döden på tal, och menade att det måste finnas någon som vågade bryta tystnaden kring döden och tillåta samtal om döden i föreningslivet. Malte, 80 år, konstaterade:

"Jag säger mitt på möten där jag vågar, där jag kommer åt att säga till." Något som han återkommer till vid dessa föreningsmöten är: "Jag vet ju också det, att vi är försent döda, borde inte finnas kvar. Vi är för kostsamma. Vi är försent döda."

Malte ville även få föreningsmänniskorna uppmärksammade på det han kallade begravningsindustrins sätt att lura av äldre människor sina besparingar:

Jag menar det, det är en stor grej det här att de ska hålla på och begrava och kosta på en jävla massa pengar och blommor och skit som inte går till någonting annat än till de här kråkorna som sitter närmast på staketet för att riva åt sig det lilla som finns. Det alltså, det är en stor humbug hela skiten alltså. Och vi säger att vi är icke - vi är inte så där kyrkligt inställda i Sverige, men likafullt så håller vi på och plockar av, speciellt änkorna, deras sista skärvar.

Malte fortsatte sitt resonemang med att omnämna hur han upplevde att PRO:s medlemmar mottog hans budskap:

Alla som man pratar med i de här termerna blir i stort sett chockade - Hur kan man vara på det där viset? och - Hur kan man ha sådana där tankar? Det är jag som vågar säga så där, ingen annan vågar. /.../ För alla hyssjar och tycker att man går in på saker som man egentligen inte ska prata om, fast man egentligen borde prata väldigt mycket om det. Det är ju inte klokt alltså. /.../ Det är ingen som vågar stå upp för de tankarna. Det, alltså det är en ynkedom egentligen, att inte folk vågar tala ...

Det ansågs betydelsefullt att få prata om döden även i andra sociala sammanhang än i familjekretsen och i vänkretsen. Föreningslivet utgjorde alltså en arena för några där man hoppades att det skulle finnas en öppenhet kring döden och där man också faktiskt pratade om döden. 


\section{Sammanfattning}

I det här kapitlet har frågan om vilka erfarenheter äldre människor har av möten med döende och död i det vardagliga livet diskuterats, med fokus på samtal med människor i familjekretsen, vänkretsen och föreningslivet. Hände det att de intervjuade pratade med andra människor om döende och död? I vilka sammanhang skedde det? Ansåg de intervjuade att sådana samtal var viktiga?

Det framkom tydliga kontrasterande mönster i studien. Några intervjuade betonade betydelsen av att kunna samtala om döden - både utifrån praktiska/instrumentella övervägande men också utifrån mer existentiella och "terapeutiska" behov. Andra tonade ned betydelsen av samtal om döden. De som betonade vikten av att få prata, samtalade med anhöriga och vänner, men även med personer som de träffade i någon förening. Föreningslivet innebar engagemang och gemenskap som många värdesatte högt. Även om det var livet som prioriterades där, kunde föreningslivet ibland användas som en plattform för existentiella reflexioner kring döden. Att emellanåt kunna prata om döden i vardagen ansåg många intervjuade som värdefullt, men det byggde på att man hade tillit till dem man pratade med. Betydelsen av samtal hade dock inte bara att göra med existentiella och "terapeutiska" behov av att få prata för att hantera känslor kring ett svårt ämne, utan också om upplevelsen av ansvar för att berätta om de egna önskningarna inför livets slut. Det rörde sig sålunda om samtal av mera praktisk/instrumentell karaktär i syfte att vägleda de anhöriga och vänner innan det kanske var för sent. Det kunde också vara fråga om att planera tillsammans och skapa förutsättningar för ett värdigt avslut.

Andra intervjupersoner ansåg i stället att döden borde tonas ned eller helt undvikas i umgänget med de allra närmaste anhöriga och nära vännerna för att inte störa och skada relationen med dem. Att mildra mötet med döden genom att visa känslor, prata med andra, etcetera, ansågs av vissa vara överflödigt. I några fall handlade det också om bristen på tillit. Man kände inte varandra tillräckligt väl för att prata om döden. Sådana samtal, menade man, kunde ge upphov till rädsla. Det fanns inte heller någon anledning att samtala, inga behov att grubbla över döden, särskilt om man också kände sig frisk. Man behövde sålunda inte vara öppen med döden varken praktiskt, existentiellt eller "terapeutiskt". Döden skulle man antingen bearbeta själv eller prata om när man själv var döende eller skröplig. 
Äldre människors föreställningar om den egna framtiden, döendet och döden

I detta kapitel diskuterade jag huruvida de intervjuade samtalade med någon eller några andra människor om döende och död. I nästa kapitel handlar det i stället om olika dimensioner av ett "efter döden" - alltså om funderingar som de intervjuade hade om det som kanske händer efter livets slut. 


\section{KAPITEL 7}

\section{Efter döden}

Jag har kommit till ungefär mitten av intervjun med Göte, 83 år, då han häller upp kaffe och till det serverars flera sorters goda kakor. Det är Götes fru som har bakat dem, och nu befinner sig hon för tillfället i vävstugan och väver mattor, men ändå är hon i högsta grad närvarande i samtalet. Göte använder nämligen pronomen "vi" i lika stor utsträckning som "jag" när han berättar. Vare sig det gäller hälsa, planer inför framtiden eller frågor kring döden, så utgår han ifrån dem tillsammans - "vi" menar, tycker, säger, planerar, etcetera. Det gäller för övrigt även på frågan vad som kommer att hända efter döden. Göte berättar om det fasansfulla att någon av dem så småningom kommer att bli lämnad ensam, att religionen och existentiella frågor har blivit viktiga för dem, att de har samma syn på döden och vad som händer efter och hur man vill bli ihågkommen. Däremot råder ingen samsyn när det gäller den egna begravningen och betydelsen av den. Göte vill att den ska bli något riktigt extra och att den ska bli välbesökt och oförglömlig, medan han tror eller snarare säger sig veta att frun vill ha en stillsam begravning med enbart de närmsta anhöriga närvarande.

De tidigare kapitlen tog upp frågor om döende och död med fokus på det förflutna och ett här och nu perspektiv. I detta kapitel handlar det i stället om olika dimensioner av ett "efter döden" - alltså om det som kanske händer efter livets slut. Temat efter döden inbegrep flera perspektiv, vilket Götes utsaga ovan visar på, och handlade sålunda inte bara om den egna döden. Det gällde i lika hög grad tankar på vad som kanske väntade de efterlevande efter dödsfallet. Efter döden var ett tema som gav upphov till blandade känslor. Likt Götes resonemang var även de övriga deltagarnas funderingar uttryck för olika innebörder av temat. Några berättade att de hade funderat en hel del under senare år, och en av dem sade: "För när man kommer upp i ålder så får man ju sådana där lite filosofiska utlägg om natur och död och himlen och Gud och så vidare". Men det gällde inte alla, några hade nästan aldrig funderat på detta - vad som sker efter döden - och ansåg det ganska bortkastat att ödsla tid och kraft på sådana funderingar. Några menade dock att ämnet väckte engagemang och att det också kunde blotta inre föreställningar om den egna självbilden. Någon påpekade: "Ja, nu avslöjar det ens fantasier och storhetsvansinne, eller något sådant". 
Det här kapitlet fokuserar forskningsfrågan: Vilka föreställningar har äldre människor kring vad som kommer att ske efter den egna döden? Kapitlet är uppbyggt kring följande två centrala mönster som framkom i analysen, och som går att sammanfatta som $-i$ evighet och $i$ förgänglighet. Flera innebörder i dessa mönster kom till uttryck i de intervjuades berättelser. Det rörde både världsliga och andliga föreställningar. De världsliga föreställningarna om "i evighet" handlade om att intervjupersonerna på något vis började förbereda sig för en tid i framtiden som inte längre inkluderade dem själva, ett sätt att "förlänga livet" och få "evigt liv". De andliga föreställningarna om " $i$ evighet" handlade om att intervjupersonerna ansåg att det fanns något slags liv efter döden, att på något sätt förbereda sig för detta liv, och vad ett liv efter döden kunde innebära. I kontrast till detta mönster "i evighet" kom mönstret - "i förgänglighet", också till uttryck i de intervjuades berättelser. De världsliga föreställningarna om "i förgänglighet" handlade om att intervjupersonerna knappast fann någon mening med ett efter döden. Man hade inte några förhoppningar om att kunna "förlänga livet" och få "evigt liv", och därför förberedde man sig inte heller för en tid i framtiden som inte längre inkluderade dem själva. De andliga föreställningarna om "i förgänglighet" handlade om att intervjupersonerna ansåg att det inte fanns något slags liv efter döden: döden innebar det absoluta slutet. Det som också är viktigt att understryka är att de två mönstren - $i$ evighet och $i$ förgänglighet - inte motsvarar en viss grupp eller kategori av intervjupersoner. Att det alltså skulle handla om två mönster som utesluter varandra. Vart och ett av dessa mönster motsvarar förhållningssätt till ett efter döden. En och samma intervjuperson kan alltså ge uttryck för de två mönstren i en och samma berättelse, likaväl som någon annan enbart ger uttryck för ett av mönstren i sin berättelse. Exempelvis kunde en person prata om $i$ evighet utifrån andliga föreställningar samtidigt som hon gav uttryck för $i$ förgänglighet utifrån världsliga föreställningar, och tvärtom.

Utöver att kapitlet är uppbyggt kring mönstren $i$ evighet och $i$ förgänglighet, struktureras kapitlet också utifrån ett antal teman som knyter an till de två centrala mönstren. Först kommer teman om de världsliga föreställningarna - närvaro vid begravning - val av gravplats - ihågkommen - avtryck på eftervärlden. Därefter kommer temat om de andliga föreställningarna - efter döden då?

\section{Närvaro vid begravning}

Två divergerande resonemang $\mathrm{i}$ de intervjuades berättelser om närvaro vid begravningar framkom. Ett knöt an till mönstret $i$ evighet medan det andra knöt an till $i$ förgänglighet. Å ena sidan påpekade några intervjuade att de nog skulle uppskatta om anhöriga och vänner deltog vid deras 
begravning. För dem som i detalj hade förberett "den sista föreställningen" var det självklart att de ville att ceremonin skulle vara välbesökt, men även för dem som knappast hade planerat något var det viktigt att de närstående samlades en allra sista gång för att minnas dem. $\AA$ andra sidan menade somliga att det inte alls kändes speciellt betydelsefullt att någon besökte begravningen. En anledning som nämndes var att de inte själva kunde "närvara" vid detta tillfälle. Följande kontrasterande mönster framkom i analysen - ett värdigt och oförglömligt sista farväl som knyter an till "i evighet" och - ett nedtonat sista farväl som knyter an till "i förgänglighet".

\section{Ett värdigt och oförglömligt sista farväl}

Ett återkommande resonemang kring huruvida det var viktigt för de intervjuade att någon deltog i deras begravning var: "Vet inte, egentligen är det väl egoistiskt. För mig betyder det ju inget, jag är ju död då". Men efter en stunds funderande blev det påtagligt att detta likväl var en ganska betydelsefull fråga. Bertil, 84 år, påpekade: "När jag ligger där då, framme vid koret, då kan jag ju inte veta vilka som kommer, men trots det, nu när jag lever så vill jag ju gärna se mina anhöriga där /.../ det tror jag är bra". En aspekt i deras resonemang handlade om en slags egoistisk sida av saken, det vill säga, att kunna se sig själv i en sådan framtida situation var av betydelse trots att man inte skulle kunna uppleva eller ha kontroll över den. Det kom tydligt till uttryck i Götes, 83 år, önskan om att vilja bli uppmärksammad med en välbesökt och minnesvärd begravning och därmed en förhoppning om att slippa försvinna i det tysta:

Ja, jag tror nog inte att jag skulle vilja ha en dödsannons att begravningen har skett i stillhet eller hur man nu uttrycker sig, bara med släktingar. Jag är nog så pass fåfäng så jag tycker att alla de man har känt i livet eller varit i kontakt med i olika sammanhang alltså, kan gott komma på begravningen. Men sedan om den ska vara storslagen eller inte det tror jag inte det finns någon anledning till alltså. Men jag vill nog inte försvinna i det tysta fullständigt utan liksom ändå bli lite uppmärksammad.

I Götes fall tycktes det sociala nätverket bestå av ett ansenligt antal personer som han närde en förhoppning om att de skulle delta i hans begravning. Det märktes också av hans livsberättelse att både det yrkesverksamma livet och engagemanget $\mathrm{i}$ föreningslivet hade genererat ett brett socialt nätverk. I sin studie När det sociala kapitalet växlas in beskriver religionssociologen Gustafsson "att antalet närvarande vid en begravning är en indikator på vilket socialt kapital den döda - och/eller de efterlevande - är i besittning av" (Gustafsson, 2003, s. 13). Flera intervjuade, som likt 
Göte tycktes ha ett stort och varierande socialt kapital att "växla in", framhöll vikten av en välbesökt begravning.

Ett annat skäl till varför den egna begravningen ansågs som viktig var tidigare släktleds tradition att ha påkostade tillställningar när någon släkting gick ur tiden. Hade man dessutom planerat inför den egna begravningen in i minsta detalj var det väsentligt att också den begravningsceremonin blev pampig, välbesökt och minnesvärd. Olga, 85 år, som i stor utsträckning hade en traditionell syn på döden, underströk begravningsceremonins kollektiva och sociala begivenhet: "Och så ska det vara kalas / ... / där ska det vara middag, med soppa, varmrätt och dessert". Detta synsätt skiljer sig en del från de mera postmoderna synsätten på begravning, Åkesson säger:

Att investera i sociala begivenheter /.../ begravningen är i dag en markering av familjär intimitet och innerlighet, av personlighet och individualitet, snarare än en kollektiv och social begivenhet vidöppen för alla. Dödens intimisering och individualitet understryks av musik, färger, symboler och texter vilka väljs för att stämma överens med den dödes personlighet. Det är detta som är centralt, inte den ekonomiska förmågan uttryckt i stora fester eller påkostade gravmonument (Åkesson, 1997, s. 91).

Även erfarenheter av tidigare begravningar påverkade intervjupersonerna i deras resonemang. Hade de upplevt en vacker begravning med många gäster så gav det också en förhoppning om att den egna begravningen skulle bli lika välbesökt. Några siffror uppgavs dock aldrig på hur många besökare som behövdes för att det skulle räknas som en "bra begravning". Enligt undersökningar gjorda på 1990- och 2000-talen var det genomsnittliga antalet besökare vid en begravning ungefär 35 individer (Gustafsson, 2003, s. 26). Däremot satte några intervjupersoner en nedre gräns. De drog några paralleller till begravningar som hade upplevts som "tragiska" eller "ovärdiga avslut", vilket de absolut inte ville skulle upprepas vid den egna begravningen. Bland andra, Asta, 77 år, berättade om en begravning som hon hade bevistat och som hon hade upplevt som en sorglig syn i kyrkan då endast den avlidnes dotter, hon själv och prästen hade varit närvarande:

Det som jag tycker är mest tråkigt det är när någon går bort, för jag har varit på en sådan begravning, vi var, dottern och så jag, det känns hemskt alltså. Då har de haft så många vänner som inte kunde komma.

I detta fall tycktes det ha varit frågan om ett ganska omfattande socialt kapital, som den avlidne besuttit och som av någon anledning aldrig kom att "växlas in" vid begravningen. De intervjuade som oroade sig över att 
begravningen inte skulle bli välbesökt, tycktes dock ofta vara de som inte hade någon omfattande umgängeskrets och de som var mindre engagerade i föreningslivet. Deras oro handlade om att dagens människor var så upptagna av allehanda livsuppgifter att de kanske skulle ha svårt att hinna med deras begravning.

En allt vanligare företeelse på senare år har blivit att fler väljer "bort ceremonin vid begravningen" eller väljer "kremering utan ceremoni". Enligt Aggedal (2003; 2010) finns det flera skäl till dessa "trender". Först och främst kan det handla om ekonomiska aspekter, det vill säga, det blir billigare utan de ceremoniella inslagen. En annan aspekt som framhålls är att äldre människor inte vill vara till besvär och därför väljer att inte "tvinga" anhöriga till begravningen. Ytterligare ett skäl som omnämns är att vissa avlidna är "socialt döda" - de har varken släktingar eller vänner i livet och därför blir det heller ingen ceremoni (Aggedal, 2003; 2010). De individer som kremeras utan ceremoni brukar benämnas "direktare" (Dahlgren \& Hermanson, 2006, s. 19). Den oro som de intervjuade kände rörde knappast den ekonomiska aspekten eller att de på något vis skulle personifiera en "direktare", snarare handlade det om en ängslan över att de närstående kanske inte skulle ta sig tid att delta i begravningen ${ }^{14}$.

De intervjuade nämnde också andra skäl till varför de hoppades att släktingar och vänner skulle delta vid deras begravning. Dessa skäl hade en annan karaktär, de tycktes vara mindre egennyttiga och i stället handla mer om de närståendes väl och ve. Först och främst menade några att en begravning faktiskt fungerade som ett slags "bokslut" eller "en högtidlig markering av slutet på ett liv", där anhöriga och vänner samlades för att ta ett sista farväl. Om det då samtidigt var välbesökt så skulle det kännas som en värdig avslutning: "Jag tycker att det skulle vara en värdig begravning" om det kom folk och "det är ett uttryck för en viss tillgivenhet från vederbörande som går på begravning". Nora, 76 år, menade att begravningsceremonin med dess musik och psalmer "blir ju en länk" mellan liv och död.

Ofta blir det sociala nätverket kring den avlidne som allra tydligast vid begravningstillfället då alla anhöriga, vänner och arbetskamrater träffas för en sista gång (Gustafsson, 2003, s. 197). Några menade också detta, att det skulle kännas "trevligt", "hoppfullt", "tröstfullt", "uppskattat" och mindre "sorgesamt" om de visste att det skulle komma människor till begravningen. Jens, 72 år, och Hans, 77 år, påpekade:

\footnotetext{
${ }^{14}$ Ett annat sätt att kunna delta vid någons begravning om man inte har tid eller möjlighet är via Skype: P4 Blekinge: http://sverigesradio.se/sida/artikel.aspx?programid=105\&artikel=5113231; Kyrkans Tidning: http:/www.kyrkanstidning.se/nyhet/folj-begravningen-internet
} 
Men visst, nu då så här, i ett framförperspektiv så det är klart att man ändå hoppas att man ska bli ihågkommen. Och att begravningen är ett led i det då, alltså blir det ju något sorts bokslut över den här personens liv ändå. Och det är klart att om man är medveten om det innan man dör skulle jag väl anta att det också ger en viss tröst, levt ett liv och att jag har vänner och så där.

Jag tycker nog att de här begravningssamlingarna har sitt värde. Själv vet jag inte, jag är inte sådan person så att jag har så väldigt många som är nära vänner som skulle stå och gråta så att säga. Men det skulle väl vara några som kom dit och möjligen kunde ha glädje av att man talade om det här livet som jag har varit del av och fick umgås lite.

Med andra ord, de argument som framfördes ifråga om varför det var betydelsefullt med välbesökta begravningar, var snarlika de skäl intervjupersonerna själva hade då de gick på en begravning. De ville göra ett "bokslut", såväl på en privat nivå för att visa sin aktning för den döde, men även gemensamt på ett kollektivt plan med de närstående. Detta ligger i linje med det Åkesson säger:

Vid död och begravning behöver människor också känna sig som del av något större helt. Detta oavsett om begravningen sker med kristna eller borgerliga förtecken. Begravning handlar om gemenskap, om människans villkor, troende eller inte (Åkesson, 1997, s. 106; se även Walter, 1994, s. 156).

Dessa intervjuades funderingar på den egna begravningen kan sammanfattas med att det mycket handlade om att begravningen skulle utgöra ett oförglömligt minne och värdigt sista farväl, och att de inte skulle behöva försvinna i det tysta - något som knöt an till mönstret "i evighet".

\section{Ett nedtonat sista farväl}

Några intervjuade menade att det inte alls var speciellt väsentligt att deras begravning blev minnesvärd eller välbesökt - "nej, det kvittar, tycker jag" och "en begravning med massvis med folk är [inte] något jag traktar efter". En anledning som inte sällan uppgavs var att de inte själva kunde "vara närvarande" och det var därför ovidkommande om deras begravning blev besökt av få eller flera. "Nej, jag är ju död", men menade samtidigt att de närmaste anhöriga ändå kanske skulle tycka det vore betydelsefullt med ett avslut. En deltagare sade: "De där ceremonierna, de är ju egentligen för de efterlevandes skull, alltså, för att vederbörande har ju ingen sådan nytta eller glädje av det". För några tycktes det dock handla 
om att de absolut inte ville ha en begravningsceremoni överhuvudtaget: "Helst inte. Det är bara det att jag kan själv inte styra det där". En av de intervjuade ansåg till och med att det här med begravningar var ett "humbug", och betonade den ekonomiska aspekten och framförallt "kråkornas" - ska läsas begravningsentreprenörernas - "ockerfasoner":

Jag menar det, det är en stor grej det här att de ska hålla på och begrava och kosta på en jävla massa pengar och blommor och skit som inte går till någonting annat än till de här kråkorna som sitter närmast på staketet för att riva åt sig det lilla som finns. Det, alltså, är en stor humbug hela skiten. Och vi säger att vi är icke - vi är inte sådär kyrkligt inställda i Sverige, men likafullt så håller vi på och plockar av, speciellt änkorna, deras sista skärvar. Bara för att det är några kråkor som ska ha pengarna. Det är drastiskt men så är det $/ \ldots /$ jag har sagt till frun att se till att jag blir bränd på sjukhuset. Och inte något mer.

En annan aspekt som dök upp lite överraskande i detta sammanhang handlade om att några intervjuade funderade på att påpeka för anhöriga att de inte ville ha någon dödsannons eller nekrolog i tidningen efter att de hade avlidit. Ett skäl som angavs var den ekonomiska aspekten:

Jag skulle inte kunna tänka mig att de ska sätta ut en annons så att de ska tjäna 2000 spänn på att jag har dött också. För det är ju så, jag menar tidningarna skriver inte dödsannonser gratis. Alltså, jag är medveten om att jag är ekonomisk, krasst ekonomisk i just i den här grejen...

Men det fanns också en existentiell aspekt i detta att avstå från en dödsannons. En intervjuad sade: "Vi [syftar även på sin fru] tror inte vi vill ha någon dödsannons". Deras död skulle inte kungöras offentligt, endast de närmaste behövde veta vad som hänt och tidpunkt för begravningen. De var heller inte speciellt angelägna att hålla reda på gamla bekanta som hade gått bort, varför de undvek att läsa dödsannonser och nekrologer. Gustafsson påpekar att "en dödsannons i dagens Sverige förefaller vara näst intill att betraktas som en social rättighet /.../ normen är alltså att ett dödsfall ska annonseras men något mer än var tjugonde" väljer att inte annonsera i dagspressen (Gustafsson, 2003, s. 44). Att annonsera ett dödsfall i en tidning har funktionen av en rituell handling, det vill säga, annonsen blir en "offentlig markering av att någon lämnat samhället, att någon passerat gränsen mellan liv och död" (Gustafsson, 2003, s. 44).

En annan möjlighet att minimera antalet gäster var att $\mathrm{i}$ dödsannonsen meddela att begravningen skulle ske "i stillhet" eller "i den närmaste familjekretsen". Det sker enligt statistiken i ungefär var femte dödsannons (Gustafsson, 2003, s. 43) och tycks vara vanligare i samband med äldre 
människors begravningar i motsats till yngres dödsfall: "Sådana dödar inbjuder till synlig ritualisering och kollektiva manifestationer kring dödsfallet" (Åkesson, 1997, s. 126). För de intervjuade var det alltså inte de ekonomiska aspekterna avgörande för deras syn på begravningsgästernas vara eller inte vara. Inte heller handlade det om att de tillhörde kategorin "socialt döda" eller att där inte fanns något socialt kapital att "växla in". Snarare handlade det om att offentliggörandet av deras död skulle ske i så liten utsträckning som möjligt.

Flera skäl angavs till varför somliga inte ansåg det så viktigt att den egna begravningen var välbesökt - det spelade inte någon roll eftersom de själva inte kunde delta och de föredrog en begravning i stillhet med de allra närmaste närvarande. Det handlade om ett nedtonat sista farväl som mer knöt an till mönstret "i förgänglighet".

\section{Val av gravplats}

De intervjuades resonemang och funderingar om var de ville bli begravda, kom mycket att handla om gravplatsen, dess fysiska placering på kyrkogården, vilka preferenser de hade kring val av stenar, minneslund, var de trodde deras anhöriga ville "besöka" dem efter döden, etcetera. Några hade bestämt var de ville bli gravlagda. Andra ansåg att det fick de anhöriga ta ställning till, medan några inte alls hade funderat. En deltagare började exempelvis reflektera över gravplatsen under intervjun: "Jag ska fråga Lisa, dottern, om jag ska begravas här eller vi har ju en familjegrav i Stockholm. Ska jag ta upp det med henne, vad tycker du?". En aspekt i de intervjuades berättelser handlade om huruvida det var graven eller minneslunden som borde utgöra platsen där minnen skulle skapas, eller om det helt enkelt fanns andra platser för sådant? En minst lika väsentlig aspekt handlade om möjligheten att kunna "synas" även efter döden, det vill säga, en gravsten med namn möjliggjorde ett längre "i evighet", vilket en gravsättning i minneslunden kanske inte skulle göra. Följande mönster framkom i analysen: det ska synas var man är begravd - det spelar ingen större roll var man gravsätts som knyter an till mönstret "i evighet" och - det ska inte vara någon grav som knyter an till mönstret "i förgänglighet".

\section{Det ska synas var man är begravd}

Några av de intervjuade menade att det var viktigt att följa seder och bruk vid valet av gravplats. Olga, 85 år, berättade om vikten att följa traditionen och bli begravd i familjegraven på kyrkogården intill bykyrkan och det tycktes också vara väsentligt att låta gravstenen förmedla vad Olga passionerat hade ägnat livet åt: 
Det är klart jag måste ligga där också. Och det ska inte vara kremering utan det ska vara en riktig gammeldags begravning /.../ Och det ska stå på min gravsten /.../ 'landsting, tingsrätt, hembygd'.

Även Inga, 91 år, hade planer på var hon ville bli begravd. Hon pendlade i sitt resonemang mellan dels den egna släktens familjegrav och dels makens familjegrav:

En familjegrav som är så här stor där min svärmor, svärfar, faster och ja, flera ligger. /.../ Jag undrar om inte vi [den döde maken] kunde ligga där, kan vi få vara med i det där gänget. / .../Vi har vi en grav uppe i Värmland nämligen, min man var värmlänning, underbart vacker kyrkogård som de har där. Så att då har jag sagt, ja och då får jag väl ligga där då. Men jag vill gärna, jag tycker inte riktigt om att den ligger vid vattnet, jag skulle vilja flytta på graven. /.../ För jag skulle vilja ligga lite högre upp i backen. /.../ Men jag har nog lite pretentioner på var jag vill ligga faktiskt.

Några menade att poängen med familjegraven var att den utgjorde just en markerad gravplats. De hade själva uppskattat att få ha en markerad plats att besöka och de ansåg att deras närstående också skulle ha den möjligheten i framtiden att kunna minnas vid en gravplats. Graven skulle så att säga bli den sociala och den andliga mötesplatsen (Sörensen, 2006, s. 167ff). Man ansåg det också väsentligt att gravstenen skulle synas för eftervärlden. Värdet av att få en egen gravsten kontrasterades mot att gravsättas i en minneslund, vilket innebar att bli anonymiserad på något vis. Det fanns så att säga ingen tydlig plats där man kunde skapa minnen eller minnas: "För att det är väldigt neutralt, säg att vederbörande ligger i minneslunden och så på någon kulle sätter man någon blomma". Däremot skulle det kännas bättre med en tydligt utmarkerad grav: "Det ger en viss närhet att man vet att här finns vederbörande" eller "en liten namnplatta" eller minnessten som påtagligt visade vem som var gravsatt - "för att det känns ju lite anonymt när man går till en minneslund, när man [kom till] allhelgona, det står 500 ljus eller någonting sådant där".

De här intervjuade ansåg det som viktigt att efterlevande skulle ha möjlighet att besöka deras grav för att minnas och skapa minnen. De ville helst inte försvinna anonymt i någon minneslund - det fanns en innebörd av mönstret "i evighet" i deras resonemang.

\section{Det spelar ingen större roll var man gravsätts}

Några av de intervjuades resonemang handlade mycket om att ta hänsyn till vad de närstående hade för åsikt vid val av gravplats. Anade de att anhöriga inte var särskilt intresserade av att sköta en grav så ansåg de att 
det vore enklare om den egna askan blev nedsatt $i$ en minneslund - de ville nämligen inte ligga någon anhörig till last. Karin, 90 år, sade: "Det får de bestämma själva för jag vill inte att de ska ha dåligt samvete för att de inte går och sköter och hälsar på och lägger blommor och ser till det. De ska slippa, de får bestämma minneslund eller om jag ska ligga ihop med föräldrarna". Även Gerd, 70 år, var inne på samma linje: "Jag vill inte utsätta mina barn för det. Tjafs om vem som ska gå till mammas grav och vem som ska sköta och vem, ja, det vill jag inte utsätta dem för". De ansåg också att det fanns andra fördelar med minneslund: "Det här med minneslunden är väldigt bra. Den vet man att den är alltid omskött". Men ibland var det inte alldeles okomplicerat. Maja, 78 år, berättade om sina tankar inför valet av gravplats:

Det jag inte tycker om i det här sammanhanget det är att här i Stockholm där begravs vi på Skogskyrkogården och jag har ju tänkt mig att jag ska brännas, kommer man in i systemet lite fortare, askan, tar inte så lång tid. Men problemet är att askan strös i en talldunge och jag älskar inte tallar. Hade mycket hellre blivit strödd i en ekdunge eller björkdunge men det blir det ju inte.

Det var inte heller ovanligt att de intervjuade hade erfarenhet av ovårdade gravplatser och därför inte ville att det skulle upprepas: "När vi kommer ner där så står det ju ofta några vissna blommor, då har ingen varit där, så där ser man ju lite av olägenheter med det där". Den misskötta graven framstår som en skymf mot den döde, och som ett skräckscenario för människor som funderar på den egna framtida gravplatsen, och därför önskar man i stället att begravas i minneslund (Åkesson refererar till Berglund [1994], 1997, s. 139). De intervjuade gav även uttryck för att de själva inte alltid hade varit så förtjusta i att behöva sköta sina anhörigas gravar, och ville därför inte tvinga barn eller barnbarn att ombesörja skötseln av en grav (jfr Lukkarinen Kvist, 2007). Det fanns också åsikter om att det inte var vid gravplatsen som minnen skulle väckas kring de döda, dessa minnen bar man alltid med sig och därför behövdes inte heller någon gravsten som minnesmärke för eftervärlden. Nora, 76 år, nämnde:

Ja visst, det är gravar och visst man kan gå men jag märker ju att det är mer sällan jag går till mina föräldrars nu. För de är liksom inte där i alla fall. Men samtidigt vet jag ju de som har en grav de går regelbundet till och sitter och pratar och det är väl olika hur man tänker eller är, eller hur. Jag vet inte riktigt. Det är väl det som får mig lite kluven till den här idén med: "för all framtid", det är ju inte där minnet finns, det finns ju hos de som lever och minns personerna, sedan, vad är det för mening att ha något som är för all framtid på en kyrkogård? Jag vet inte, jag har ofta undrat hur de har 
tänkt just när de köpte sina platser och att det var för all framtid...

Men om de å andra sidan trodde att de närstående ville ha en plats att besöka och för att minnas, så var de inte främmande för att gå dem till mötes:

Det har vi väl inte tänkt på men det tänker jag mig väl ändå. Det vill nog de efterlevande ha ett ställe, det är ju så. Jodå, det tänker jag mig väl någon liten minnessten, det tycker jag väl. Men jag har full respekt för de som tänker annorlunda, med minneslund och man strör ut askan och så, det är ju mer symboliskt och det är ju mer att man har ett ställe dit man kan rikta, jag tänker på när jag går till mina föräldrars grav och så blir det ändå konkret på något sätt, att man vet att de lämningar som blev då, de ligger där. Det blir ett stöd för minnet och reflektioner och sådant.

Åkesson menar att det har blivit allt vanligare att ta hänsyn till de anhörigas vilja: "I enlighet med tanken om dödens intimisering är det föga förvånande att människor strävar efter närhet också till graven. Kanske skulle många helst vilja ha askan hemma, eller graven på tomten, för att dagligen kunna umgås med sina döda i privat avskildhet" (Åkesson, 1997, s. 135).

Flera intervjupersoner ansåg att de anhörigas åsikter var viktiga och de verkade också flexibla i sin inställning till var den framtida gravplatsen skulle ligga och var deras anhöriga skulle få möjlighet att minnas. De insåg att eftervärlden inte heller måste minnas dem för evig tid genom att namnet förevigades på en gravsten - i stället var minneslunden en plats där minnet av dem skulle finnas kvar under en begränsad tid för de efterlevande.

\section{Det ska inte vara någon grav}

Ståndpunkterna varierade men några av de intervjuade ansåg att det var oväsentligt med en gravplats. Någon menade: "Om man dör på sjukhus så kunde de elda upp en [där] /.../ jag har sagt till [partnern] att se till att jag blir bränd på sjukhuset" och tycktes överhuvudtaget vara kritisk till det här med att begrava människor: "Tänk den där stora fina kyrkogården, Skogskyrkogården, vad fan är det för någonting att ha? Tänk vad mycket fina hus de skulle [kunna] ha där". Det återkom i några utsagor att den kristna ceremonin att bli gravsatt var otidsenlig. En av dem som var tveksamma till en konventionell gravplats sade: "Som protest mot alla regler och alla religiösa konstigheter att man ska grävas ner av praktiska skäl" och en annan: "Därför att det här med gravar som vi har varit med om, det är omodernt i dag, tycker jag". 
Ett annat skäl att överväga frågan - gravplats eller inte - handlade om att närstående ändå inte hade tid att besöka graven eller att man inte ville bli kvar som död när resten av familjen flyttade (jfr Lukkarinen Kvist, 2007; Åkesson, 1997, s. 133). Någon menade: "Min mamma sade så här Jag vill inte ha någon grav för att det är ingen som går [dit], ingen som har tid att gå! Jag håller med henne om det”. Ett par intervjuade funderade på att låta de anhöriga sprida askan i havet eller på någon plats i landskapet som de var förtjusta i. Skälen till denna idé varierade. En kistbegravning såväl som en urnbegravning kunde upplevas som klaustrofobiskt: "Annars ska de komma med en urna det verkar inte riktigt, det verkar som ett fängelse /.../ Det är bättre att vara i friheten" och "inte tycker [jag det] är så roligt, att tänka på att lägga sig i den där lilla urnan och stå i jorden. Ja, men då hoppas jag att själen redan har gått". Andra menade att människan tillhörde moder jord och därför skulle återbördas dit:

De kan sprida askan här [i den närliggande naturen]", så brukar jag säga, "nej det får vi inte" säger min fru, "skit i det, det har väl ingen betydelse, det är väl ingen som bryr sig". Det beror på vad barnen säger, om de vill ha någonstans att gå och så vidare, då kan vi säga att vi ligger i minneslunden men egentligen ligger vi utströdda där borta på berget. Eller i någon fjällsjö eller någon annanstans. Man tillhör ju det här jordklotet.

Det fanns alltså flera aspekter till att inte vilja gravsättas. Å ena sidan av rent praktiska och ekonomiska skäl, och å andra sidan som en slags protest mot traditionen, religionen och det otidsenliga. Men det tycktes finnas ytterligare skäl. Uttryck gavs för en aspekt av förgänglighetstanken - att eftersträva en anonymitet genom att inte märka ut en definitiv plats att minnas och skapa minnen vid. Det var samtidigt en förändring i förhållande till tidigare traditioner som gav ett uttryck för förnyelse och en omvandling av värderingar, kanske. I stället för att ha en grav att gå till skulle graven lika väl kunna ersättas med att närstående tog fram fotografier för att minnas: "De kan titta på foton sedan - där är gubben...".

\section{Ihågkommen}

Samtalen med de intervjuade kom också att handla om huruvida man ville bli ihågkommen eller inte, på vilket sätt man ville bli ihågkommen och hur länge. Nästan samtliga intervjuade ville på ett eller annat sätt, mer eller mindre, bli ihågkomna av anhöriga och vänner eller åtminstone hade de förhoppningar om det. De menade att det fanns olika sätt att bli ihågkommen, bland annat genom dödsannonser, nekrologer, minnesord på begravningar, olika minnesceremonier eller i samband med det vardagsnära livet. För vissa verkade denna hågkomst inte vara tidsbegrän- 
sad, medan andra menade att minnena av dem inte kunde bestå för evigt. De tycktes inte heller vara speciellt oroliga för att bli ihågkomna i negativa ordalag. De ansåg också att det "egentligen" inte gick att påverka hur man blev ihågkommen. Isak, 75 år, och Hans, 77 år, resonerade kring detta:

Ja, det vore ju ett nederlag om de skulle säga att: "det var skönt att bli av med honom, en jävel i alla år", utan en respekterad människa, hygglig och ja. Det är ju lite svårt att påverka. När man läser de här dödsrunorna så är det ju så oändligt kraftfulla personligheter som har dött och, även vid hög ålder och allt positivt som sägs. Jag tror, man är inte sanningen så nära när man [skriver] dödsrunan. Det är väl både och i dem, fast man skriver ju inte där, det mest negativa.

Ja, några slags positiva omdömen är det klart att man skulle vilja ha. Sedan är ju människan komplicerad så att det finns ju sidor som man kanske själv är lite medveten om men andra har mera tydliga åsikter om att de inte är så bra. Det kommer säkert att finnas också. Men om man summerar med någon slags poängberäkning på olika parametrar så skulle man ju vilja att slutsumman var positiv $i$ alla fall. Men inte så att man lever för det målet att det ska bli så, det, det vill jag inte, så långt vill jag inte gå.

Följande kontrasterande mönster framkom i analysen - att förbli odödlig $i$ minnet hos efterlevande som knyter an till mönstret "i evighet" och - snart glömd som knyter an till mönstret "i förgänglighet".

\section{Att förbli odödlig $i$ minnet hos efterlevande}

Att på ett eller annat sätt bli ihågkommen av anhöriga och vänner efter döden var någonting som flera hade förhoppning om. Detta kom till uttryck på olika sätt. Några sade kort och koncist: "Med blommor på graven på födelsedagen", "man vill bli älskad i döden" eller "jag har ju massvis med fotografier och det kan de ju titta på om de har lust". Det vanligaste skälet handlade dock om att de ville bli ihågkomna för att de hade uppträtt som en god förebild, som till exempel inför barn, barnbarn eller vänner. Flera egenskaper förde de intervjuade på tal för att definiera vad det innebar att vara en god förebild för någon och som de upplevde att de hade varit: "hygglig och bra person", "varit till stöd och glädje", "omtyckt kamrat", "hjälpsam", "respekterad människa", "hedersvärd", "genomtänkt moral" och "pigg och glad". Olga, 85 år, sade:

Sedan får man hoppas att folk tycker att ens liv inte har varit alldeles felaktigt och att man har gjort någonting för någon annan. Man har betytt någonting för någon annan, det skulle man ju gärna vilja veta om man har gjort. 
Olga berättade även att hon inte var orolig för att bli helt bortglömd och drog en parallell till sitt 85-års kalas: "Och när det kom så mycket folk på min födelsedag så tänkte jag att jag måste inte ha misslyckats helt i alla fall". Olgas resonemang ligger i linje med vad annan forskningen säger: "How to be remembered by others was essential, and they wanted to tell that they had lived in a way that they did not have to be ashamed about, and that they now could leave a worthy memory behind" (Nilsson, Sarvimäki \& Ekman, 2003, s. 354).

Det fanns även en annan aspekt i deras resonemang kring viljan att bli ihågkommen - att meningen med begreppet evigt liv i själva verket låg $\mathrm{i}$ hågkomsten:

"Det som är evigt liv", sa han [pastorn], "det är ju minnet, som de efterkommande har av den som har dött". Jag tycker det ligger en del visdom i det. Det är helt enkelt att, många människor gillar ju inte att bli glömda, de vill inte bli glömda, om man säger så, men minnet finns förhoppningsvis kvar i de efterkommande generationerna. Och det kanske är det som är evigt liv.

Göte, 83 år, uttryckte sig på ett annat sätt: "Jag tror nog det att fortsättningen sker i det man har åstadkommit under livet, man kan väl säga nu att det är ju barnen, barnbarn och sådant /.../ det är väl kanske livets mening det där, att man ska se till att man har återväxt".

Ett återkommande tema i forskning om döden handlar om människor och deras "preparing for a time in the future that excludes themselves" (Clarke \& Warren, 2007, s. 482). Människan har en förhoppning om att någon av hennes gärningar, goda egenskaper, efterlämnade föremål, etcetera, ska "ärvas" och minnas av kommande generationer och bli till en symbolisk odödlighet - symbolic immortality - åt eftervärlden. Ofta har dessa åstadkomna saker, egenskaper, föremål i sin tur ärvts från tidigare generationer, och som en röd tråd genom generationerna går dessa symboliska odödligheter. Begreppet myntades på 1970-talet av socialpsykologen Lifton, vars huvudpoäng är att "healthy individuals seek a sense of continuity, or immortality, through symbolic means" (Lifton [1974, 1979] i Garth Vigilant \& Williamson, 2003, s. 173ff). Det vill säga:

Most importantly, Lifton assert that pursuit of symbolic immortality gives meaning to our existence by preserving our connection to others in material ways in this life, while ensuring our continued symbolic connection to others once the mortal coil is severed (Lifton [1974, 1979] i Garth Vigilant \& Williamson, 2003, s. 173ff). 
Andra forskare har vidareutvecklat begreppet "symbolic immortality" tillsammans med begrepp som identitet, genus, klass, etnicitet (Drolet, 1990; Kastenbaum, 1974). Bland andra Garth Vigilant och Williamson anlägger en identitetsaspekt i den teoretiska diskussionen: "An understanding of the individual's quest for symbolic immortality might enrich the knowledge of identity formation and maintenance in life, and the quest for identity continuity after death" (Garth Vigilant \& Williamson 2003, s. 173ff).

Det handlade alltså först och främst om minnet av de intervjuades goda gärningar som exempelvis barnuppfostrare, filantrop, etcetera alltså en förhoppning om att hågkomsten skulle ha karaktären av en altruistisk aspekt. Det var de ädla gärningarna som skulle minnas. Det tycktes inte heller som de intervjuade lade in ett tidsperspektiv i resonemangen om dessa symboliska odödligheter, det var en hågkomst som skulle vara för evigt.

\section{Snart glömd}

En motsatt bild till den nyss beskrivna handlade om att några intervjupersoner dels inte ville bli ihågkomna och dels att minnet av dem ändå skulle komma att blekna inom kort. En av de intervjuade sade krasst: "Nja, jag skiter i om de kommer ihåg mig. Det spelar mig ingen roll". Väldigt få tänkte emellertid så. Snarare handlade funderingarna om hur länge det skulle dröja tills man var bortglömd. Några menade att deras död kanske kom att ha "ett slags nyhetens behag över sig". En deltagare påpekade: "Man blir ju aldrig så erkänd och bra som när man dör" och en annan sade: "sedan ska det hållas tal utav någon som tycker att - då får man höra lite lögner - Åh, han var så bra så, åh han var så bra så!” Det var inte ovanligt att paralleller drogs till bortgångna släktingar och vänner som de själva mindes allt vagare: "Men det är väldigt många [av ens släktingar] som blir bortglömda också". Det fanns en slags oro, men också ett faktiskt konstaterande, att de själva snart skulle bli bortglömda precis som deras gamla släktingar mer eller mindre hade blivit. Några intervjuade frågade sig hur länge de efterlevande skulle minnas dem, det kanske skulle röra sig om månader, år eller kanske upp till ett halvt sekel:

Eller så kommer de inte ihåg någonting efter en månad - Jaså han, jaså var det han som bodde där, den gamle stuten där nere, vad hette han? 50 år efter min död så finns det ingen som kommer ihåg mig en gång, om inte, barnbarnen förstås...

Innebörden av "i förgänglighet" kom att handla om att minnet av en person snart var glömt och att den symboliska odödligheten inte var odödlig 
- att tiden skulle hinna i kapp även den.

\section{Avtryck på eftervärlden}

Några av de intervjuade hade förhoppningar om att bli ihågkomna även utanför den allra närmaste kretsen av anhöriga och vänner för något betydelsefullt de hade uträttat i livet. Någon pratade om avtryck som kunde avlämnas lite här och där, i såväl föreningslivet som i yrkeslivet: "Men det finns väl ändå en hel del andra minnesmärken kanske som man har åstadkommit, det kan vara i minnet [hos] andra så att säga". Detta var ett tema som kom lite överraskande i några av de allra första intervjuerna och som jag då inte hade frågat om, men som däremot blev alltmer påtagligt $\mathrm{i}$ de efterkommande intervjuerna då temat mer medvetet fokuserades. Att efterlämna ett avtryck på eftervärlden och att bli ihågkommen "i evighet" ansågs alltså som något väsentligt vare sig man var 70, 80 eller 91 år. Det är inte svårt i detta sammanhang att dra en parallell till Baumans resonemang kring det oavbrutna strävandet efter odödlighet. Det vill säga: "Döden innebär obestridligen ett fall ner i ett avindividualiserat intet. /.../ [men] eftervärlden är den plats där förhoppningen, om än inte förvissningen, om jagets odödlighet /.../ kan investeras" (Bauman, 1994, s. 69). Därför försöker människan, individuellt eller kollektivt, medvetet eller omedvetet skapa något som har möjlighet att överleva den egna kroppsliga elimineringen. Utifrån ett historiskt perspektiv var det tidigare i princip bara celebriteter som monarker, statsmän, författare, upptäcktsresande och uppfinnare med flera som levde vidare efter döden i form av statyer, romaner, reformer, minnesmärken och årliga återkommande minnesceremonier. De hade så att säga gjort investeringar i eftervälden under sin levnad och också befunnit sig i en sådan position där de kunde bestämma vad som skulle prägla samhällets värderingar av dem - vad stommen i hågkomster skulle bestå av. Detta är dock ett fenomen som inte är ovanligt i dag i alla samhällskategorier, enligt Bauman, det vill säga, att investera i framtiden i och med att man "själv" kan bestämma vad stommen i hågkomsten ska bestå av. Följande mönster framkom i analysen att förbli odödlig $i$ det "offentliga minnet" som knyter an till mönstret "i evighet" och - spårlöst försvinna som knyter an till mönstret "i förgänglighet".

\section{Att förbli odödlig $i$ det "offentliga minnet"}

Ett par av de intervjuade som hade en förhoppning om att deras uppdrag och gärningar i livet skulle lämna avtryck på eftervärlden, berättade också om sina förfäders efterlämnade spår. Exempelvis berättade en att fadern hade varit en välkänd och framgångsrik idrottman som skrivit in sig i historieböckerna. En annan av dem berättade: 
Så sitter man där i kyrkan och kommer ihåg, där finns ju också grejer - som den, altartavlan har farfar skänkt och krucifixet har farmor skänkt och den var gjord av en brorson till henne och så där du vet.

Det framkom att dessa intervjupersoner inte ville vara sämre. De ville också lämna något spår efter sig precis som tidigare generationer hade gjort - både symboliskt och materiellt.

Något som också återkom var det engagemang eller de uppdrag som de hade haft i föreningslivet och som de hoppades bli ihågkommen för. Kanske hade de varit en uppskattad ordförande eller en driven kassör i en förening och hoppades därför att gärningarna och resultaten skulle bli ihågkomna: "Jag vill bli ihågkommen som någon som man kunde använda sig av. Någon som kunde ställa upp, om man sedan är ordförande eller något, men att överhuvudtaget någon som man kunde använda sig av". En annan nämnde:

Jo, det är klart om man nu ser PRO - gemenskapen alltså - jag har väl blivit genom åren, jobbat centralt alltså, ganska känd. Jag knöts ju till PRO för att jag hade en viss kompetens alltså /.../ Om man säger så här även om det låter fåfängt - jag vill nog bli ihågkommen som att jag har uträttat en del alltså. Ungefär så kan man säga.

Detta gällde även arbetslivet. Någon menade: "Ja, det verkar förmätet att säga att det vore väl roligt om de kom ihåg en, att man har varit en duktig tjänstekvinna och så där, så det skulle väl vara trevligt". Flera av dem framhöll att de hade lämnat väsentliga avtryck på yrkeslivet som de ville bli ihågkomna för:

Den här politiska verksamheten, ja, kanske, ibland så tyckte man att det var bara tråkigt, men sedan finns det väl vissa saker som man tycker att det kunde varit någonting där man kunde göra en insats. Jag skulle gärna vilja bli ihågkommen som någon som har gjort något. Jag har inte producerat mig eller något sådant, vilket är idiotiskt att jag inte har gjort för det borde jag ha gjort, men jag hoppas att några kommer ihåg att: "ja men hon, hon var inte så dum". Att jag har kunnat användas tills saker och ting.

Några nämnde att de hade efterlämnat fysiska avtryck och hade därför förhoppning om att inte bli bortglömda:

Ja, några större illusioner finns det ju inte mer än att man har varit med och skapat saker och ting och hjälpt till med viss utväxt, som det här [företaget] och det här, som alla tycker är fantastiskt och skriver böcker om. Jag har en bok som de har skrivit om mig då, där står det, det bästa som har hänt [orten] de senaste 20 åren, och så vidare och så vidare. Det är ju rätt kul. 
Men det handlade även om att de hoppades bli ihågkommen för insatser som de hade gjort för andra i det yrkesverksamma livet. Att som vårdbiträde, sjuksköterska eller läkare ha åstadkommit något bestående minne: "Jag vill nog bli ihågkommen som en människa som ändå har engagerat mig i dem, i de andra små människors verklighet, som har försökt att göra någonting för att underlätta för andra". Någon sade halvt på skämt: "Ja, jag har hjälpt väldigt många människor, när jag var socialarbetare, hjälpt enormt mycket folk. Så det hoppas jag att, var det nu ska noteras någonstans. Ska det följa med upp eller följer det inte med upp [till himlen]?".

Till skillnad från de minnen man hade förhoppning om att efterlämna hos närstående som mer hade karaktären av osjälviskhet, så verkade dessa avtryck åt eftervärlden ha särdrag av egennytta. För att citera Bauman (1994), de skulle visa att investeringen i jagets odödlighet fick en fortsättning i eftervärlden - något som knöt an till mönstret "i evighet".

\section{Spårlöst försvinna}

En kontrasterande bild till den ovan beskrivna handlade snarare om att vilja försvinna spårlöst. Att upphöra att existera och att försvinna spårlöst, menar forskare (se Strang, 2007), har människan känslomässigt svårt att klara av - upplever det som skrämmande - trots att man efteråt ändå är död. Människan vill bli ihågkommen, och hon har inte sällan en medveten såväl som omedveten stark drivkraft att vilja bli ihågkommen (Strang, 2007, s. 34). Denna drivkraft var tvärt emot nästan oväsentlig för några av deltagarna - det fanns nästintill en önskan om att få försvinna i det tysta. Utöver att bli ihågkommen av de närstående, ansåg några det inte alls väsentligt att bli ihågkomna i andra sammanhang. Hilma, 76 år, sade: "Jag behöver inte bli ihågkommen, det är bara viktigast att mina barn kommer ihåg att jag har funnits". Några menade att detta steg, att "spårlöst försvinna", kunde tas redan i samband med dödsfallet. En av deltagarna resonerade kring detta med dödsannonser och nekrologer: "Men själv vill jag inte ha något $\mathrm{i}$ tidningen, det finns ingenting och säga om mig och skriva". På några av de intervjuade lät det som om de ville försvinna ner i intet:

Men vi har ju pratat om, vi vet inte men, tycker det här med dödsannonser, vi tror inte vi vill ha någon dödsannons. Vad har man det för? Jag märkte på mig själv för en tid sedan att när man läser tidningen på morgonen, ju äldre man blir så kanske man läser alla jäkla dödsannonser. Jaha, de var födda då och de var födda då, men det där slutade jag med meddetsamma. Men jag tror att äldre människor läser mycket dödsannonser och tänker när ska jag stå där? 
Det fanns knappt något intresse av att investera i jagets odödlighet och leva vidare i eftervärlden - minne och hågkomst sågs som något förgängligt.

\section{Efter döden då?}

Avsnitten ovan handlade om de världsliga föreställningarna på livet efter döden, medan fokus i de följande avsnitten ligger på de andliga föreställningarna. Vad trodde de intervjuade skulle komma att hända efter den egna döden? Detta tema, efter döden då? gav upphov till lite olika spontana kommentarer. En av deltagarna sade skrattandes: "Vad begär intervjuaren?", medan några andra svarade att: "Ja du, det är ett stort ämne", "jag tror inte det händer någonting men det skulle ju vara jäkligt spännande att veta" och "jag visste att du skulle ställa den frågan och har funderat en del". Mer eller mindre samtliga intervjuade hade någon gång under senare år funderat på vad som skulle komma att hända efter döden. För några av dem hade dessa funderingar fått en djupare innebörd och de hade tänkt en hel del och de sade sig också vara ganska säkra på sin sak, medan några i stället konstaterade att livet de nu levde var det viktiga och därför ansågs sådana funderingar vara ovidkommande. En av deltagarna sade:

Nej, jag vet inte. Och jag kan säga att jag bryr mig inte så mycket om det. Mitt liv har jag nu och får göra det så bra som möjligt /.../ men jag går inte och tänker, jag gruvar inte och hoppas inte. Ja, i och med att jag inte tänker på det så ... har jag ingen uppfattning.

Några berättade att de emellanåt kände sig tvehågsna, ibland förekom det perioder i livet då de trodde på ett liv efter döden, medan de vid andra tidpunkter var nästan säkra på att så inte var fallet. Någon nämnde att det nästan hade med dagsformen att göra eller vilken litteratur som låg på nattduksbordet. De vacklade, men de påverkades även av sina erfarenheter. Inga, 91 år, berättade:

Ja, det har jag funderat en del på. Det har väl alla funderat på. Men det är tveeggat. Egentligen från början, så trodde jag väl bara att man försvinner liksom upp i någonting, universum. Men nu hör man ju så många som talar med de som [dött]. Jag vet inte om jag tror på det men jag måste ju. Det låter så övernaturligt om jag säger, att man kommer tillbaka till sina gamla kompisar då när man dör och träffar dem. Det har jag svårt att tro på. Man kanske blir en ande. Som försvinner. Men jag kommer ihåg, dagen efter min man dog, så hörde jag absolut en röst som sa på morgonen: - Inga, klockan är nio! Och det var han som sa det och då började man fundera att finns det verkligen något liv efter det här. Men jag har inte hört någon- 
ting sedan men alltså det var så tydligt, "att klockan är nio". Nej, och därför ibland när jag tänker tillbaka på det så tänker jag, eller kanske det är ett mellanrum, när man dör så går man väl upp kanske i någon sfär som är närmare jorden innan man försvinner, i den högre sfären. Man är ju död, man kanske inte, som vi säger död, utan fortfarande har någon kontakt.

Detta, efter döden, handlade inte enbart om huruvida det fanns ett liv efter döden eller inte - $i$ evighet och $i$ förgänglighet. Det berörde också om vad ett liv efter döden innebar och varifrån dessa bilder av ett liv efter döden kunde komma (jfr Cicirelli, 2006, s. 343). Följande teman framkom i analysen - ett liv efter döden utifrån en tro - en annan dimension på efter döden som knyter an till mönstret "i evighet" och - det absoluta slutet som knyter an till mönstret "i förgänglighet".

\section{Ett liv efter döden utifrån en tro}

Teman som återkom på ett eller annat sätt i alla intervjuades berättelser rörde existentiella och religiösa frågor. Åkesson menar att "ett uttalat intresse för religiösa rörelser och existentiella frågor [har] ökat markant på senare tid, inte bara i Sverige utan i hela västvärlden. Framförallt har det som brukar kallas för privatreligiositet en stark ställning. Med detta menas att människor sällan går i kyrkan men ändå tror på Gud eller på någon slags andlig kraft" (Åkesson, 1997, s. 100). Ett par av de intervjuade berättade att de alltid hade haft en kristen tro och hos dem fanns det "en tro och en förhoppning" om ett liv efter detta jordeliv. Det var i "himmelriket" de skulle träffa Gud och Jesus, men även vänner och "anhöriga som har gått före". David, 73 år, och Asta, 77 år, nämnde:

Jag har ju en tro på Gud, och jag tror ju att det är han som har skapat oss och konstruerat oss och då har han också, ja han har lagt in någon begränsning i det hela. Att han då, som har gett oss livet, han har rätt att ta det tillbaka. Så att för mitt eget döende så är jag väl inte orolig. /.../ I frikyrkan så har man ju hela tiden, talat om det eviga livet och att döden inte är annat än en övergång från ett liv till ett annat. Och att det har funnits med hela tiden.

Jag är inte rädd för att dö, inte alls, för jag tycker inte att jag gjort så förskräckligt mycket syndigt, så jag kan, hoppas jag, inte bli straffad /.../ men det är ju inte jag som bestämmer utan det är Gud som bestämmer om jag ska komma dit eller inte ...

Somliga pratade om ett "nästa liv", "det blir trevligt där uppe" eller "att komma hem", utan att vare sig nämna Gud, Jesus eller att de bar på en religiös tro. Men det fanns utsagor i deras berättelser som åsyftade en 
slags tro på något. En av dem kom in på detta tema när han resonerade kring känslan av ensamhet: "Och sedan, där uppe så kommer man vara ensam också, antar jag, eller var man nu hamnar - i glöden...". Någon menade också:

Ja, jag har faktiskt den här, jag vet inte, kallas naiv ibland, där jag tror att jag då kommer att få träffa alla igen. Hur det ska gå till det är den där stora frågan som jag får förklaring på då, hur det ska gå till. Men jag tror på något sätt det. Det tror jag beror på att jag har haft det med mig hela tiden.

Om några av dem inte hade varit särskilt troende tidigare i livet, så upplevdes att de på senare tid hade ägnat mer tid åt den kristna tron. De ansåg att det berodde på åldern och att den kvarvarande tiden upplevdes vara knapp. Göte, 83 år, berättade att han hade blivit mer intresserad av kristendomen under de senaste åren och av vad som kanske väntade efter livet:

Vi har ju inte varit så där påtagligt religiösa men nu tittar vi på TV varje söndag på gudstjänsten. Det är ju så vacker musik och sång och allt sådant där alltså, det är bara ren fröjd alltså. Jag vet inte om man kan säga att det tillhör åldrandet också att vilja lyssna på de här orden. Sedan, det var väl mera en slump men det var en tanke jag hade haft tidigare, jag skaffade den här nya upplagan av Bibeln och har börjat läsa lite grann.

Några hade dock börjat tvivla. Var den kristna tron rätt för mig? "Alltså okej jag anser mig väl vara kristen, det får jag väl lov att säga" men vidare i resonemanget fanns det snarare en skepsis till evigt liv, Gud och Jesus. Kurt, 78 år, berättade:

Jag tror inte på skärselden längre nämligen. /.../ Nej, det har jag inte gjort, det har jag aldrig gjort, på det sättet. Det kan väl hända en gång när man gick i skolan, man blir ju väldigt indoktrinerad i skolan - men inte skärselden då, för det har man inte trott på - men hela det här med den kristna föreställningsvärlden men det håller mer på att försvinna på något sätt.

En annan intervjuperson berättade om sitt tvivel inför det eviga livet och vart själen skulle ta vägen:

Själv tror jag ju eller hoppas i alla fall att jag kommer till ett ställe där jag inte behöver ha några bekymmer för någonting, utan allting ska ordna upp sig. Jag tror ju liksom att det finns någon som tar hand om en, i den mån de kan, så hoppas jag verkligen det. /.../ Det kan ju inte komma nya människor jämt, jämt, det måste ju bli att din och min själ måste ju någon gång tas tillbaka till någon annan människa. Sedan vet jag inte om du tycker jag är 
larvig. Men en tänker så ibland i alla fall - det kan inte finnas, det finns inte, det kan inte finnas så mycket människor annars...

Tron på någonting, tycktes för somliga vara nyckeln till en tro på evigt liv, medan andra som uppgav sig vara kristna ibland också kände tvivel i sin tro och på ett liv efter döden.

\title{
En annan dimension på efter döden
}

Några av de intervjuade sade sig inte vara anhängare av den kristna religionen och dess tro på ett evigt liv: "Jag är inte religiös", men de sade sig heller inte anamma den ateistiska synen, utan snarare definierade de sin "tro" eller "förhoppning" utifrån andra begrepp som varsel, synskhet, vidskeplighet, andlighet, spiritism, etcetera. Här handlade det alltså inte om en religion som förutsätter en gudstro. Det handlade om andlighet, som "omfattar något större, utanför oss själva. Man kan vara andlig, tro på något större, utan att vara religiös" (Strang, 2007, s. 10). Gerd, 70 år, sade:

\begin{abstract}
Man kan vara troende på olika sätt, jag tror att livet har olika dimensioner, att det finns någonting som kan leva kvar, som, ja, någon uppenbarelse för de efterlevande som kan visa sig ibland. /.../ Jag är synsk. Jag kan förutse saker ibland, och det är ibland väldigt obehagligt. Därför tror jag på något, flera dimensioner, att livet har flera dimensioner och där måste ju döden höra in också.
\end{abstract}

Resonemanget handlade ofta om att de hade fătt "kontakt" med tidigare avlidna släktingar och förhoppningen var att de efter döden skulle få samma möjlighet till "kontakt" med sina anhöriga: "Man vet ju aldrig, allt som skrivs nu om att de är närvarande. Jag vet inte om de sitter där och där. Det vet man ju inte". En deltagare nämnde:

Sedan på något konstigt vis, jag vet inte, jag tror inte på själavandring direkt men ibland så undrar man, ibland känns det som man hade kontakt. Att det finns kvar på något vis. Vissa utrymmen eller i vissa situationer så har man en känsla av att man får en kontakt ändå, att de inte är alldeles borta. /.../ Bland de som jag väl tycker att jag ibland har kontakt med, det är framför allt, alltså min pappa och jag.

Några nämnde också begreppet "själavandring" - att själen inte dog med kroppen utan att den vandrade över till en annan kropp, i dessa fall handlade det inte sällan om djurkroppar. Eller att man återgick till naturen, det eviga kretsloppet och blev en del av det igen. Naturen är ett återkommande tema i deras berättelser och har "i det svenska samhället i någon mening ersatt kyrkorummet. Det är i naturen vi finner stillhet och 
det är till naturen vi söker oss när vi är i kris, till skogen, fälten, havet, det storslagna, det eviga" (Strang, 2007, s. 21). Erik, 70 år, nämnde att han emellanåt kunde bli sittande på kvällarna på verandan med sin fru och fundera på det existentiella och naturens förlopp:

Sätta ett frö vet du, så växer det en potatis eller en morot eller ett träd, alltså man kan ju undra, all denna kemiska process som pågår överallt. Vad det är som har gjort allt det här. Om det är evolutionens miljoners miljoner år men hur började det en gång? Varför just det här runda jordklotet, mitt ute i alltihop. Man sitter här en kväll, det är stjärnklart och fint, man undrar, vad i herrans namn? Att man kan tänka så. Det är det som jag tycker är mest fascinerande. Att vi kan tänka oss ut i rymden, andra varelser och allting. Att man kan! Ja en tupp gör säkert inte det eller ankorna, de bryr sig inte, bara de hittar en mask så är de nöjda.

Även Frida, 72 år, var inne på samma linje och framhöll naturen då hon berättade en anekdot om när maken dog och det otal stjärtmesar som av oförklarliga skäl vistades utanför fönstret vid den tidpunkten på året:

"Nu tog stjärtmesarna pappas själ", säger min dotter, och det där får jag frysningar av fortfarande [när jag ser] stjärtmesar. /.../ Om det är så att han uppenbarar sig som en stjärtmes, ja vadå då, kan han väl få göra. Men ja, det är lite så där, halvskumt, runt i kring det där, som jag inte riktigt vill, om du förstår, jag vill vara rationell och tycka att nej, vad är det för larv, men det finns där. /.../ Men, så blir jag en stjärtmes, då blir jag lycklig...

Ett par intervjuade hade läst en hel del litteratur kring temat efter döden. En av dem ansåg att det var väldigt svårt att ta ställning, "det där går ju genom olika perioder, kan jag säga, att man tror det och det och så och så. Man blir ju påverkad av vad man läser, åtminstone jag, då och då kan jag tro det en tid och så nästa gång [så är det något annat]". Han berättade att just för tillfället var han upptagen med spiritism, seanser och "oförklarliga händelser" och ansåg att "är det nu definitivt slut, då känns det snopet". Fler kände att de vacklade i sin tro och att detta inte sällan berodde på dagsformen: "Och där jag står någonstans och tvekar". Celia, 86 år, berättade:

Det är ju det enda rättvisa som finns här på jorden. Än har det ju inte kommit tillbaka någon, inte tror jag att det kommer heller. Inte med de här moderniteterna och förresten så försvinner de i sina kistor också. Ja, ett samvete har vi ju. Men jag tror ju inte att jag kommer tillbaka som en fågel eller någonting sådant där. Men, jag är inte religiös heller men det finns ju någonting som styr oss människor i alla fall. Det måste de ju göra, absolut, finns det någonting som styr. Sedan kan man ju fråga sig varför det skulle 
finnas någon som kan styra - varför har de styrt så och så.

En annan intervjuperson menade att livet efter döden handlade om att "det är en elektrisk bit som går ur kroppen när man dör, något elektriskt, men jag tror inte den far och har sitt eget liv, det tror jag inte. Jag tror inte det, jag tror att är man död så är man död". Ytterligare en av de intervjuade, som hade studerat fysik och kvantfysik, menade att det fanns en sådan aspekt av livet efter döden:

All energi är oförstörbar, de energiprocesser, som min organism producerar, de korresponderar med omgivningens energi. När pumpen i min organism upphör, då upphör även energiproduceringen och organismen vissnar, och som allt annat levande återgå de biologiska resterna till energi i växtligheten i naturens processer och korrespondens med omgivningens atmosfär. /.../ det är ju det här med medvetandet och tankarna. Du tänker en tanke, den alstrar energi. Den energin, vart går den? Den förstörs ju inte, den går ju någonstans. Den sugs ju upp i atmosfären. /.../ Att det finns minnessubstanser som har fångats upp i min organism som har funnits $\mathrm{i}$ någonting annat, $\mathrm{i}$ någon annan tidigare (Denna utsaga kommer från en mailkonversation mellan intervjupersonen och mig).

För dessa intervjupersoner tycktes det ändå infinna sig ett lugn inför det som kanske väntade efter döden. Att få uppleva något slags efterspel utan att för den skull ha behövt "investera" i någon religion eller trosuppfattning. Att ha något hopp om ett liv "i evighet" kom till uttryck i deras berättelser.

\section{Det absoluta slutet}

Några av de intervjuade berättade att de inte trodde på ett liv efter döden eller att något skulle hända efter deras död. De gav alltså uttryck för aspekter av mönstret "i förgänglighet". Detta definitiva faktum beskrevs på varierande vis. Döden var enligt någon detsamma som att "knipsa en blomma" inget mer och inget mindre, eller att "maskarna äter väl upp mig". Andra svarade i stället: "Ingenting, ingenting, det kan inte bli något". Ytterligare några menade: "Det är inget annat /.../ utan vi lever och sedan kommer det att stängas av", "nej, jag tror inte att det finns någon fortsättning som följer alltså" och "jag har inga visioner om något liv efter detta, det har jag svårt att tänka mig. Är det slut så är det slut". Dessa intervjupersoner hade ofta sin ståndpunkt klar och hade haft den nästan hela livet även om de funderat kring denna eviga fråga. De tycktes ändå alltid återkomma till konstaterandet att det inte fanns något bortom livet: 
Ja, det är ju en fråga man brottas med men jag tror väl att det är slut. Ja, det finns inget där bortom. Det är väl det jag har kommit fram till. Så är det och det får man väl acceptera. Man får väl vara tacksam och glad att man har fått leva ett hyggligt liv och hyggligt långt liv.

Det var inte heller ovanligt att man ställde sina funderingar kring döden i relation till någon slags tro/gudstro. "Jag har inga religiösa dimensioner inför döden" och "Jag har ingen tanke på att, att det finns någonting efter eller blir någon framtid utan när man är väck så är man. Jag menar det, det är idioti att tro att när man dör, att det ska bli något mer av en". Den allmänna meningen var att den som ansåg sig vara realist inte trodde på sådant som ett liv efter döden. "Jag menar, är man då lite förnuftsorienterad så har man ju svårt att tro att det finns sådant" som evigt liv. Någon annan sade:

Det tar slut. Vart skulle den lilla själuslingen ta vägen bland de miljarder andra som i ett sillstim då eller, tänk dig själv? Nej. Det är helt, det är orealistiskt. Inte tror du att om de slaktar en kossa, att du tror att hennes själ kommer, ja, till någonting, i kossornas himmel. Vi är ju, det är ingen skillnad på oss egentligen. Kött och blod och lite ande och sedan slut.

Dessa intervjupersoner tog inte sällan stöd av vetenskapen för att argumentera mot föreställningar som evigt liv, himmelriket, etcetera:

Men min inställning är att det, cellerna är döda och då är det inget.

Jag menar, varför i hela friden, den där kristna föreställningsvärlden har ju rasat samman på något sätt - från det att Galileo och Kopernikus påstod att jorden snurrade runt solen. Det var väl på snudd att de blev brända för det där, utav kyrkan. Jag menar, kyrkan hade ju en föreställningsvärld som vetenskapen har skalat av, skapelseberättelsen, allting är ju på något sätt, det är ingen som tror på att Gud skapade ... på 7 dagar, det här.

Ja, jag tror jag har blivit mera realist. Att är det slut så är det slut. Det, precis som djur i skogen, de dör och sedan så försvinner de bara. Kommer andra och äter upp dem, det som är kvar. Jag menar, det blir bara ett mörker. Man vet ingenting. Det finns inget medvetande längre. /.../ Det tycker jag är helt fysiskt klart alltså.

En annan synpunkt som återkom var att döden innebar slutet på allt och att det då var dags att lämna över till de yngre generationerna: 
"Då har jag gjort mitt", så sa alltid min mamma, "nu har jag levt så länge, nu har jag gjort mitt". Och det tycker jag är en rätt så bra inställning då. Det är de andra får ta över, de som kommer efter.

Generationer kommer och generationer går och det är liksom det som är meningen med det hela, så att säga. Så ser jag väl på det.

Det föreföll som dessa intervjuade var förvissade om att efter livet så var allt slut, det fanns ingen tro på det "förlängda livsloppet" i någon andlig värld.

\section{Sammanfattning}

I detta kapitel har jag fokuserat forskningsfrågan: Vilka föreställningar har äldre människor kring vad som kommer att ske efter den egna döden? Temat efter döden inbegrep flera perspektiv och det gav också upphov till blandade känslor hos de intervjuade. Två centrala mönster framkom i analysen av temat efter döden: $i$ evighet och $i$ förgänglighet. De här mönstren motsvarade inte en viss grupp eller kategori av intervjupersoner. De ska i stället ses som skilda förhållningssätt till ett "efter döden" där en och samma intervjuperson i sina berättelser kunde förhålla sig till båda.

Det fanns flera innebörder av mönstret "i evighet" som kom till uttryck i de intervjuades berättelser. Det rörde både världsliga och andliga föreställningar. De världsliga föreställningarna om "i evighet" handlade om att intervjupersonerna på något vis började förbereda sig för en tid i framtiden som inte längre inkluderade dem själva, på ett sätt att "förlänga livet" och få "evigt liv" - en önskan om det "förlängda livsloppet". Att "förlänga livet" och få "evigt liv" kunde röra en förhoppning om att få en välbesökt och minnesvärd begravning, eller så kunde det handla om gravplatsens estetik, dit anhöriga kunde gå och minnas dem efter döden. Att "förlänga livet" kunde också handla om på vilket sätt man ville bli ihågkommen eller om vilka avtryck på eftervärlden man gjort. Man ville förbli odödlig av både egoistiska och altruistiska skäl, men man var också rädd för att försvinna i det tysta. De andliga föreställningarna om "i evighet" handlade om att intervjupersonerna ansåg att det fanns något slags liv efter döden, antingen utifrån kristna värderingar eller andliga och spiritistiska värderingar.

Ett kontrasterande mönster, som också kom till uttryck i intervjupersonernas berättelser, var "i förgänglighet". Även detta mönster rörde världsliga såväl som andliga föreställningar. De världsliga föreställningarna om "i förgänglighet" handlade om att intervjupersonerna knappast fann någon mening med ett efter döden. Man hade inte några förhopp- 
ningar om att kunna "förlänga livet" och få "evigt liv", och därför förberedde man sig inte heller för en tid i framtiden som inte längre inkluderade dem själva. Detta kom till uttryck i att vikten av den egna begravningen tonades ner, liksom viljan att ha en gravplats. Det kunde också handla om att man inte ansåg det nödvändigt att bli ihågkommen, eller att lämna avtryck till eftervärlden. Detta "i förgänglighet" handlade om att "man var ju död då, och dessutom skulle man ju snart vara bortglömd". De andliga föreställningarna om "i förgänglighet" handlade om att intervjupersonerna ansåg att det inte fanns något slags liv efter döden döden innebar det absoluta slutet.

Det här kapitlet har handlat om de intervjuades tankar och resonemang om vad de tror sker efter den egna döden. I nästa kapitel fokuserar jag på framtiden - tankarna om tiden fram till döden. 



\title{
KAPITEL 8
}

\section{Tid kvar}

\begin{abstract}
Vi sitter i Celias, 86 år, vardagsrum och pratar om tider som flytt, om nuet och om framtiden. På bokhyllan finns fotografier på barn och barnbarn, men även ett bröllopsfoto. Hon berättar att hon och maken gifte sig när hon var 19 år, att de fick tre barn och att maken plötsligt avled i mitten av 60talet. Då, vid dödsfallet, hade funderingarna på framtiden stannat av och för ett kort ögonblick hade hon upplevt att hon inte hade haft någon framtid. I dag när Celia tänker på framtiden så ställer hon sig frågan: "Ja, hördu du, tänker man en framtid när man är så pass gammal som jag är?". Hon konstaterar därefter att hon tar en dag $\mathrm{i}$ taget och att hon inte har några planer inför eller förväntningar på framtiden. Det är här och nu som gäller. Senare under intervjun framkommer det däremot att hennes funderingar på framtiden tar henne längre än enbart till här, nu och morgondagen. Hon berättar vilka studiecirklar hon planerar att delta i under hösten, hon ser fram emot att kunna sätta upp ytterligare ett fotografi på bokhyllan, denna gång på ett barnbarnsbarn som väntas inom kort. Dessutom nämner hon att det finns så mycket intressant med livet att hon har en förhoppning om att få leva till hon blir 95, 100 år.
\end{abstract}

De tidigare kapitlen har handlat om de intervjuades erfarenheter av och tankar kring döende och död utifrån det förflutna, nutid och om tankar om vad som händer efter döden. Det här kapitlet fokuserar framtiden tankarna om tiden fram till döden. Det framgick av samtalen med de intervjuade att de arbetade med flera tidsperspektiv samtidigt som de reflekterade över sin återstående tid. Det fanns olika sätt att prata om tid kvar. Det var alltså inte ovanligt att intervjupersonerna resonerade kring sin kvarvarande tid, likt Celia i citatet ovan, som någonting som tidsmässigt kunde begränsas till dagen eller morgondagen, och som ofta också var rumsligt kopplad till hemmet. Men samtidigt kunde de se sig själva i en framtid som sträckte sig längre än bara till morgondagen och som rumsligt var kopplat till annat än bara hemmet. I våra samtal kring framtiden föreföll alltså deras uppfattning av den kvarvarande tidens utsträckning i tid och rum som föränderlig och mångfacetterad. Det var ett tidsprat där tid och rum knappast verkade vara fast och fixerat vid något enda tillfälle, ett tidsprat där det tycktes existera olika synsätt för att kunna forma den egna personliga framtiden.

Den forskningsfråga jag diskuterar i detta kapitel är: Hur ser äldre 
människor på sin framtid och på den tid som är kvar? Analysen synliggjorde tre mönster som går att sammanfatta under följande rubriker - tidshorisonten här och $n u$ - tidshorisonten på visst avstånd - tidshorisonten ganska långt borta. Kapitlet inleds med ett avsnitt som ger en kort beskrivning av dessa mönster.

\section{Det flexibla tidrummet}

Nurmi (2005) menar att människans tankar på och agerande inför framtiden utgör centrala inslag i människans väsen. Med andra ord, människan tänker på vad som kommer att hända i framtiden, hon har ofta åsikter om framtiden, kan planera inför framtiden, och hon lägger också ner kraft på att förverkliga uppsatta framtida mål. Denna orientering inför framtiden uppstår emellertid inte i ett vakuum - den vilar på tidigare erfarenheter och på intressen, motivation, värderingar, känslor och attityder hos människan. Flera intervjupersoner ansåg att de hade levt ett långt liv, och utifrån deras berättelser kunde urskiljas att de också funderade kring den återstående delen av livet och hur det kanske skulle komma att gestalta sig. I kontrast till gängse förställningar om att äldre har sin (fram)tid bakom sig (Howarth, 1998, s. 673), ansåg samtliga intervjuade att de hade en framtid och att det dessutom fanns en mening med framtiden. Det var den personliga framtiden de intervjuade oftast syftade på, men ibland handlade det även om närståendes framtid såväl som om framtiden generellt (jfr Nilsson, Sarvimäki \& Ekman, 2003, s. 360). En uppfattning tycktes vara att ett långt liv och en hög uppnådd ålder inte hindrade dem från att tänka och reflektera kring en framtid. Parallellt med de här funderingarna om framtiden fanns det också en medvetenhet om att den kvarvarande tiden inte kunde vara för evigt. Det var i detta spänningsfält mellan livet och dess förgänglighet som de arbetade med flera tidsperspektiv samtidigt som de funderade kring den kvarvarande tiden. Det handlade om tidsperspektiv som ständigt var under konstruktion, som var förankrade $\mathrm{i}$ deras erfarenheter, och som hade olika utsträckningar i det framtida tidrummet.

Intervjupersonerna valde att på varierande sätt ge uttryck för tankar och föreställningar om framtiden och hur de förhöll sig till den kvarvarande tiden. Tre mönster framträdde i analysen. Här ges en kort beskrivning. I varje mönster framkom ett antal centrala teman, som i några fall kunde återkomma i de olika mönstren: 
- Tidshorisonten här och $n u$ - tiden berörde nästan enbart dagen och morgondagen; tiden blev till stora delar rumsligt kopplad till hemmets sfär; den individuella situationen betonades; vardagliga rutiner, hemmet och ensamhet var teman som fokuserades; erfarenheter och minnen fick stort utrymme; planer, förväntningar och drömmar tonades ned.

- Tidshorisonten på visst avstånd - tiden berörde nästan enbart de kommande veckorna, månaderna eller halvåret; tiden blev inte sällan rumsligt förknippad med världen utanför hemmets sfär; den kollektiva situationen betonades; erfarenheter och minnen såväl som förväntningar, aktiviteter, engagemang och gemenskap i föreningslivet fick stort utrymme.

- Tidshorisonten ganska långt borta - tiden och rummet upplevdes som elastiskt och ibland näst intill obegränsat; den individuella situationen betonades; planer, förhoppningar och drömmar framhölls; uppsatta tidmarkörer, anhörigas gener och att leva länge underströks.

Vart och ett av dessa mönster kan sägas motsvara ett förhållningssätt till framtiden - förhållningssätt som deltagarna kom att inta under samtalen. För att enklare kunna förklara och förstå och framförallt kunna särskilja dessa förhållningssätt, har jag alltså valt att använda en horisontmetaforik där vart och ett av förhållningssätten motsvaras av en tidshorisontmetafor. Det som är viktigt att understryka är att en tidshorisont inte motsvarar en viss grupp av intervjupersoner. Samtliga tre tidshorisonters innebörd förmedlades mer eller mindre av alla intervjupersonerna och i en och samma berättelse. De intervjuade pendlade mellan de parallella tidshorisonterna, och den kronologiska åldern föreföll inte spela någon roll, vare sig man var 70 eller 91 år. Arnes, 86 år, och Gerds, 70 år, berättelser får illustrera dessa pendlingar:

I slutet av samtalet med Arne frågar jag honom hur han har upplevt intervjun. Arne inleder med att säga: "Jag tänkte det här, att ha föreställningar om framtiden alltså, det kom mig att dra lite på mun, för att har jag någon framtid egentligen? Annat än att stiga upp, äta, höll på att säga gå på dass, äta och gå och lägga mig, också läsa tidningen - det är ju min framtid. /.../ För att i mitt fall, när jag tänker, jag tänker inte på framtiden, jag tänker på vad jag ska göra nu och hur jag har det nu och vad jag ska göra i morgon och så vidare. Jaa, i morgon är ju också framtiden kan man säga" (tidshorisonten här och $n u)$. 
När Arne berättar om hur han upplever att det är att bli äldre/gammal, så säger han en bit in i sitt resonemang: "Jo visst, vet du vad jag gör sedan då, jag åker till Stockholm varenda vår i maj och hälsar på. Hälsar på - gör en sådan där tur - fyra, fem, sex bekanta som bor där. Ja, jag kör bil dit, vänta så ska du få höra" (tidshorisonten på visst avstånd).

När Arne pratar om sina vänner och om att de blir färre och färre, så kommer han också in på den kvarvarande tiden: "Gamla barndomsvänner och arbetskamrater, både han och hon gick bort, och där i den längan gick det bort en, de är ju i min ålder. Man lever ju kanske i farozonen lite grann, har jag tänkt på, så att... jag tänkte stå ut till 90 år, till att börja med, och att bilen ska räcka, jag tror inte bilen räcker längre" (tidshorisonten ganska långt borta).

En och samma person pendlade alltså mellan tidshorisonterna under en och samma intervju. I Arnes fall rörde det sig om en orientering som sträckte sig från i dag och minst fyra år framåt i framtiden. För Gerd, 70 år, handlade det om en orientering som sträckte sig från nuet och minst 10-15 år framåt i framtiden (jfr Celia, 86 år, i inledningscitatet).

När Gerd berättar om hur hon upplever att det är att bli äldre/gammal, så nämner hon efter ett tag: "Och hoppas att jag får vara med i många år till. Då kan man ju fråga sig vad många år är, jag har ju funderat på det, mina föräldrar blev inte så gamla, mamma blev 80 och pappa 84, och ja, jag hoppas ju jag får vara med i en 10-15 år till, det hoppas jag absolut" (tidshorisonten ganska långt borta).

Då Gerd får frågor om både den tid som varit och hur hon ser på framtiden så återkommer hon alltid till att hon lever här och nu: "Alltså jag är, det sa jag förut, jag är så här mycket, här och nu" (tidshorisonten här och nu).

När Gerd berättar om sina aktiviteter så kommer hon in på hur hon planerar kommande veckor med inslag av fysisk träning och barnpassning: "Jag känner att jag måste hålla i gång för att jag ska orka, speciellt min yngsta dotter och hennes barn, jag hjälper till en á två gånger i veckan". Och detta gäller också träffarna med väninnorna och hur de planerar inför de återkommande årliga träffarna (tidshorisonten på visst avstånd).

\section{Tidshorisonten här och nu}

När frågor om framtiden ställdes framkom ett mönster i de intervjuades berättelser, som handlade om att den kvarvarande tiden tidsmässigt berörde de intervjuades "i dag och morgondag". Asta, 77 år, påpekade: 
Jag tänker inte så mycket på det, att jag kanske har ett år kvar att leva eller tio, det tänker jag aldrig på. Jag tänker så här, att huvudsaken är att jag kan gå upp varje morgon och sköta mig själv, det är det enda jag tänker liksom.

Det förefaller inte vara något ovanligt mönster att ta en dag i taget. Det återkommer i forskningen om äldre människor och deras förhållningssätt till den egna framtiden (jfr Nilsson, Sarvimäki \& Ekman, 2003, s. 345ff; Ågren, 1995, s. 55ff; 1998). Det som jag diskuterar i följande avsnitt är: Vad innebar tidshorisonten här och $n u$ för de intervjuade? De teman som framkom i analysen var - att ta en dag $i$ sänder - hemmet - vardagliga rutiner - ingen större idé att planera eller drömma om framtiden - en känsla av ensamhet.

\section{Att ta en dag $i$ sänder}

Ett resonemang som återkom i de intervjuades berättelser handlade om deras upplevelse av att den kvarvarande tiden inte sträckte sig längre än till dagen eller morgondagen. Det fanns varierande sätt i att ge uttryck för detta korta tidsperspektiv (jfr Clarke \& Warren, 2007, s. 469ff). Några ansåg att de, de facto, nästan inte hade någon framtid: "Det finns knappast någon framtid för en längre", därför var det heller "knappt meningsfullt att tänka på framtiden" mer än i ett kortare perspektiv. En av de intervjuade upplevde till och med att det inte fanns någon kvarvarande tid alls att tala om och att döden nästan väntade runt hörnet. Anledningen till detta förhållningssätt var erfarenheter av en nyligen avliden familjemedlem och som hade inneburit att den tidigare uppsatta förväntningshorisonten hade raserat:

I: Jag har ingen framtid, tycker jag.

M: Du känner så nu?

I: Jajamensan, det gör jag. Det känns som jag är färdig med livet, det låter ju hemskt när man har barn och barnbarn, men...

Ett annat återkommande påstående handlade om de intervjuades förhoppning om att framtiden ändå inkluderade ytterligare en dag. Men i denna förhoppning fanns det ibland en antydan till oro, som baserades på minnen av gamla släktingar som plötsligt hade gått bort. De intervjuade var exempelvis ängsliga över att kanske inte få vakna nästa morgon, för att döden skulle kunna slå till under natten. Det kom till uttryck på varierande vis: "Man kan öppna ögonen i morgon, så säger man - Tack Gode Gud att du kanske har gett mig en dag till!" och "hoppas man får stiga upp nästföljande morgon”. Var det inte döden de oroade sig över, så var 
det i stället att inte längre klara av de vardagliga rutinerna: "Jag hoppas kunna gå på muggen själv". "Jag har lagt mig till med det att - här och nu - det är bäst", menade någon. Det var inte ovanligt att de i dessa sammanhang nämnde att de hade levt ett bra liv, de var glada för att fortfarande vara i livet och varje ny dag sågs som en "bonus". Det blev "viktigt att ta vara på varje dag". Här ställdes varje ny dag i relation till livet som varit, och varje ny dag blev på så sätt en förlängning av gårdagen och av livet. Mycket handlade också om att framtiden var den tid som utgjordes av nuet och nuet ansågs som något väsentligt att ta vara på. Morgondagen var osäker "jag lever i dag och jag försöker att göra det bästa jag kan göra av dagen, morgondagen vet jag ingenting om". Elsa och Carl, båda 71 år, resonerade kring detta:

Man vill ju gärna ha kvar det här livet på något sätt. När det är som bäst så att säga. /.../ Ja, vår framtid, man vill väl nästan att den stagnerar här. Stannar här ett tag och att vi är här. Vi får gå ut på altan och sitta där, kanske med lite god ost, lite vin, och ha det mysigt. Titta på en färja eller båt eller vad som helst. Vad ska jag säga? Ja, det höjer ju ens kvalitet. Ja, man sätter värde på det, gör vi ju.

Några menade också att de inte skulle bekymra sig så "himla mycket" för framtiden utan i stället försöka vara nyfikna, oavsett om de bara levde för stunden:

För man är så himla nyfiken så man vill se hurdant det är i morgon också.

Det är väl ingenting konstigt med framtiden som man bekymrar sig för, den är ju nu.

Ja, jag är nog en sådan där som tar dagen som den kommer.

De kände alltså ingen större ängslan inför framtiden, kom döden så fick den komma. De som hade denna inställning framhöll i stället vikten av att ta vara på tiden och vara optimistiska - att ta en dag i sänder. De tycktes inte heller i så stor utsträckning väva samman andra tidsskeden i funderingarna kring framtiden. Varje dag var en ny dag utan tydlig koppling till framtiden. Dagarna tycktes alltså komma och gå eller som Gerd, 70 år, valde att uttrycka det: 
Alltså jag är, det sade jag förut, jag är så här mycket, här och nu, så jag planerar alltså inte för mitt åldrande, nej, vilket jag märker att en del utav mina väninnor faktiskt gör. Jag vet inte om det är bra eller dåligt men jag är en sådan här människa och har alltid varit så jag tänker så här - Ja men det ordnar sig nog!

I flertalet utsagor upplevdes tidshorisonten nära i tid och den kvarvarande tiden tycktes på så sätt mycket begränsad och inom räckhåll. Bertil, 84 år, upplevde att framtiden nästan flöt ihop med nutiden:

Jag har häcken full med nuet, jag hinner inte med framtiden så mycket och jag oroar mig inte, nej. Ändå vet jag teoretiskt sett att jag kan ju inte ha så väldigt många år kvar, men det bekommer mig ingenting. Det är nu det gäller, jaa. /.../ Nej, den [framtiden] tänker jag inte på, jag lever nog mest för dagen. /.../ Nej, det tror jag inte att jag har några längre [förhoppningar], utan jag är nöjd med om det får vara som det är i dag, att det inte blir sämre bara, alltså. Så länge som det är som det är i dag så är jag nöjd. Jag har inga större saker jag behöver utan jag lever gärna som jag lever i dag, och det får bli min framtid det också. Så att det är jag nöjd med.

Karin, 90 år, gav uttryck för att det inte enbart var den kvarvarande tiden som hon tyckte var begränsad och krympande. Hela tillvaron verkade på något vis krympa, både i tid och i rum: "Man krymper så här och var ligger det och var finns det och sådana där saker". Hon åsyftade att hon inte längre rörde sig så långt hemifrån - att inte orka eller kunna utföra aktiviteter som hon hade gillat tidigare i livet, gjorde att tillvaron krympte till att blott handla om dagen och morgondagen.

\section{Hemmet}

Hemmet var ett ofta återkommande tema i berättelserna, dock med olika innebörder. När de intervjuade betonade detta med att "ta en dag i sänder" tycktes de också för det mesta avse att deras framtid skulle äga rum innanför hemmets väggar. Någon menade: "Och nu sitter jag här och vad gör jag, jo, vad jag gör i dag? Läser tidningen, lokaltidningen, och så den där draken, DN, sudoku och korsord och sedan läser jag böcker, och ser på TV på kvällen". Den kvarvarande tiden förknippades med andra ord inte sällan rumsligt och materiellt med hemmets sfär och det föreföll nästan som att den sista delen av livet skulle komma att utspela sig där: "Ja, det innebär att jag vill inte flytta härifrån. Jag vet flera /.../ [som tycker]

likadant, [hon] och jag, vi ska stanna. Ja, vi ska stanna”. Arne, 86 år, konstaterade på frågan Hur tänker du kring din framtid?: 
Det har jag ingen [framtid], det är det här alltså [syftar på situationen och huset, genom att peka på sig själv och runt sig]. /.../ För att i mitt fall när jag tänker, jag tänker inte på framtiden, jag tänker på vad jag ska göra nu och hur jag har det nu och vad jag ska göra i morgon och så vidare. Ja, i morgon är ju också framtiden kan man säga.

En återkommande kommentar var att hemmet innebar "trygghet", "lugn och ro", "den centrala punkten", och "jag känner mer och mer att jag kan vara hemma och ha det bra". Celia, 86 år, och Hilma, 76 år, beskrev hemmet på följande vis:

Jag har alltid tyckt om mitt hem, älskar det. Och jag kan gå, jag kan vara ensam, jag är inte beroende, jag har inte varit beroende av att ha massor folk omkring mig eller så där, inte...

Ja, du vet att är man en äkta kräfta, så är det, det som är viktigt. Inte för att man ska komma in i skalet eller gå bakåt men just att ha den här tryggheten. Det är därför jag försöker att ha något så när skapligt i omgivningen här. Men jag har inga prydliga saker för det, men jag har sådant som jag tycker om att ha runt om mig...

Någon liknade hemmet vid en borg som inte vem som helst fick tillträde till, och det var där man kunde förena exempelvis existentiella funderingar med hushållssysslorna. Även om alla inte liknade hemmet vid en borg blev det tydligt att det nästan inte fanns några andra alternativ till hemmet. Det omhuldades och spelade en betydande roll för deras förankring i tillvaron och förhållning till framtiden. Det var också i hemmet som flertalet ville bo den resterande delen av livet och det var där de flesta ville sluta sina dagar. Någon konstaterade gällande hemmet att det blev "mindre och mindre viktigt det här att ta sig härifrån".

När detta tidsperspektiv kom på tal föreföll funderingarna kring något annat framtida boende, exempelvis särskilt boende, ibland bli lite dramatiska - "Då får man passa på att dö innan [man blir tvungen att flytta]". Någon drog också paralleller till tidigare erfarenheter:

Jag vet hur man blir, hopföst, där kan man väl säga att man funderar på att bli gammal och när man ska dö och då kommer alla de där tankarna. Då kommer det. Då tror jag, de människorna tror jag nog har det i sitt huvud nästan varje dag. Att när ska detta slut och vad blir det och vem kommer? Är någon här då? Jag skulle bli galen, som jag känner i dag.

I de flesta fall ställdes inte hemmet i bjärt kontrast till andra boendeformer. Visserligen förekom det åsikter kring andra boendeformer, men de 
gav inte upphov till några särskilda förväntningar eller grubblerier. Attityden till andra boendeformer var snarare att: "Så länge jag orkar så ska jag bo kvar här, men annars får jag sälja" och "det får bli som det blir". Andemeningen var nästan att - varför oroa sig över att behöva flytta när man ändå bara levde för dagen och morgondagen.

\section{Vardagliga rutiner}

Något som återkom i berättelserna och som gällde det korta tidsperspektivet var de vardagliga rutinerna:

Arne, 86 år, sade att hans framtid egentligen bara bestod av regelbundna rutiner som att stiga upp, äta, gå och lägga sig och också läsa tidningen. Han nämnde också att han försökte klara av de flesta av de vardagliga sysslorna själv, men att han ibland fick hjälp med städningen.

Bertil, 84, år: Och sedan sköter jag ju mig själv, handlar, lagar mat, tvättar och städar, vilket är mycket tråkigt för övrigt att städa, men det måste göras också.

De ansåg att så länge de klarade av att uträtta de vardagliga sysslorna på egen hand, så kunde de också förhålla sig till en framtid. Rutinerna tycktes bli viktigare i de sammanhang där de intervjuade uttryckte att de tog en dag i sänder. Värdefullt var att klara av hygienen, att kunna gå ut och handla, laga mat och att städa i så stor utsträckning som möjligt utan någon större inblandning från vare sig anhöriga eller hemtjänst. Ett återkommande citat var: "Jag vill sköta mig själv" och "man känner att man inte vill ligga andra till last". Även om rutinerna ibland avfärdades som enahanda av de intervjuade så fyllde de en viktig funktion på flera sätt både för tillvaron i nuet och för framtiden. Att ha denna framförhållning, det vill säga, att kunna ta en dag i sänder förutsatte att man kunde utföra de här vardagliga rutinerna.

\section{Ingen större idé att planera eller drömma om framtiden}

Att planera inför framtiden föreföll inte fylla någon större funktion då man inte visste vad som kanske skulle komma att ske framöver (jfr Nilsson, Sarvimäki \& Ekman, 2003, s. 359; Ågren, 1998). De planer som gjordes upp sträckte sig oftast inte tidsmässigt bortom dygnets tjugofyra timmar. Karin, 90 år, sade lite skämtsamt: "Jag lägger väl inte upp några större planer vad man ska göra om 15 år och så där, precis /.../ Nej, jag tycker det räcker ju nu och sedan får man väl se hur det går". Celia, 86 år, nämnde att hon inte planerade inför framtiden men att hon försökte leva dagen så intensivt som om det vore den sista, vilket hon ansåg vara vä- 
sentligt nu när hon hade nått denna höga ålder:

Nej, jag kan inte se framtiden så att jag skulle kunna planera någonting. Men däremot så lever jag intensivt, när jag nu har min ålder inne, jag lever intensivt, det gör jag. Jag tar vara på allt om man säger så, men planera det gör jag inte. /.../ Nej, utan jag lever, om man säger att jag sätter värde på varje dag som går, och lever den dagen intensivt, man vet ju aldrig vad morgondagen har i sitt...

Några intervjuade ansåg också att de hade kommit till en punkt i livet då "igångsättningsmotståndet [var] mycket högre" och "lusten avtagit" att planera resor och dylikt. Visserligen bedömdes det finnas en "limit faktiskt", men det var ändå ett faktum:

Men det där har lite avtagit, den där lusten, jag tycker jag har det så bra här, faktiskt /.../ Det är ju det att jag trivs ju så bra /.../ oförskämt att säga men jag trivs så bra med mig själv, kanske beroende på det att jag uppskattar ju dagen och tackar faktiskt för att jag är som jag är. Det har nog blivit lite grann att jag börjar bli bekvämare, kallar man det då när man inte vill säga att man inte orkar, då säger man att man har blivit bekvämare. Ja, låter bättre. Det är nog på väg åt det hållet. Nej, jag tycker att jag behöver. Man kommer ibland till en punkt i livet då man säger att - Jag har ju sett det mesta!

Framtidsdrömmar var något som somliga förknippade med de yngre generationerna. Det tycktes inte finnas något större utrymme för drömmar vid denna ålder: "Det tycker jag att man hade förr [drömmar] men nu har de visst försvunnit. Ja, bara jag får ha det så här, liksom". Man resonerade också över att vid denna ålder så hade man förhoppningsvis fått sina drömmar förverkligade. Carl och Elsa, båda 71 år, sade:

Ja, men samtidigt är det ju så att man tycker, men jag menar vi har ju också haft någon målsättning med vårt liv och drömmar, och nu tycker vi ju de flesta av dem har vi ju fått se förverkligade. Det är klart så att nu känns det inte som att vi har sådana där enorma förväntningar på framtiden.

Även Malte, 80 år, var inne på samma spår: "Är man 80 år, då är faktiskt drömmarna uppfyllda eller också blir det inget, det är bara så". I stället kunde drömmarna handla om att man hoppades hålla sig frisk: "Jag vet inte, jag har inga framtidsdrömmar, annat än att hålla mig frisk ända tills jag dör, ja, du förstår vad jag menar." 


\section{En känsla av ensamhet}

Ett tema som ofta återkom spontant $\mathrm{i}$ berättelserna och med olika innebörd handlade om ensamhet och dess möjliga konsekvens för framtiden. Några intervjuade sade sig inte alls uppleva en sådan känsla, men fruktade däremot en framtid som kanske skulle kantas av ensamhet. Andra deltagare nämnde dock att de kände sig ensamma redan nu och de liknade denna ensamhet vid "en jättestor ... avgrund". Ofta saknade de någon att samtala med eller leva tillsammans med. Det var framförallt när de betonade att de tog en dag i sänder som detta omnämndes. Det var upplevelsen av ensamhet $i$ bemärkelsen att inte längre vara någons partner, ett civilståndsmått av begreppet ensamhet (Andersson, 2002, s. 146f), som framkom i deras berättelser. Inga, 91 år, berättade om sin bekantskapskrets som tunnades ut för vart år som gick och om sin känsla av ensamhet:

Nu läste jag i tidningen just, att den sista goda vännen, en fru, gick bort. 93 var hon väl då. Så att det där glesnar är ju en tomhet. Jag har inte några kvar ifrån den generationen, min egen generation kan jag säga, utom två stycken i Uppsala /.../ Jag har inga gamla att vara tillsammans med. En skolkamrat har jag, som gör mina fötter, hon är nästan lika gammal som jag, det är ju också otroligt, men annars, jag har inga kvar. Och min man han blev 78 och hans systrar och bröder, det finns inga kvar. På det sättet så blir man ju ensam i den här generationen. Och det tycker jag, det kände jag riktigt för första gången då när jag läste den här dödsannonsen. Att nej, ja nu är det slut, helt slut, med just det där och det tycker jag gjorde lite ont /.../ Hela den tiden är som, nästan bortsopad och bara minnen kvar.

En intervjuad menade att upplevelsen av ensamhet ibland gick att undvika, i alla fall för stunden: "Ibland kan jag tycka att det kanske blir lite långsamt här. Men då går jag och träffar folk borta i affären, handlar något...". De gav också uttryck för en annan variant av begreppet ensamhet och då handlade det i stället om en självvald ensamhet. Några tycktes vilja leva dagen och morgondagen och dess förankring i hemmet i en slags självvald ensamhet. Asta, 77 år, och Hilma, 76 år, berättade:

Sedan har jag varit ensam, och ja, det är väl lite, lite tråkigt ibland, att vara ensam, men jag vill inte ha någon man mera, utan jag vill sköta mig själv.

Men jag trivs, jag har så mycket annat att göra så jag trivs med min ensamhet så här. /.../ Så att därför har inte jag haft några svårigheter med ensamheten som många andra har. Tror inte jag kommer att ha det i fortsättningen heller. 
Att ta en dag i taget innebar att olika betydelser av ensamhetsbegreppet framhölls, vilka varierade i innebörd - å ena sidan betonas saknaden av någon att leva och umgås med - å andra sidan underströks det frivilliga valet att vara ensam och också att trivas med den tillvaron $\mathrm{i}$ hemmet.

\section{Tidshorisonten på visst avstånd}

Ett annat mönster handlade i stället om att den kvarvarande tiden tidsmässigt berörde en lite längre tid - de framförvarande veckorna, månaderna eller halvåret. Fred, 77 år, berättade att sedan han blev pensionär hade hans tid upptagits av olika aktiviteter som i mångt och mycket berörde detta tidsperspektiv:

Det var precis det jag kände själv, när jag blev pensionär - aldrig haft så mycket att göra som när jag blev pensionär. För det första är det grejer som man vill göra, som man har gått och tänkt att ha tid att göra. Det andra är då att ens fru jagar på en hela tiden: "men du, du har inget att göra, du kan ju, sätt de där blommorna eller gräv de där groparna eller snickra det där och så vidare", så det blir ganska stressigt att bli pensionär.

Gällde det inte aktiviteter som rörde familjekretsen så handlade det i stället om allt från föreningsliv, religiöst liv, kulturliv och sällskapsliv till fackföreningsliv och informellt omsorgsarbete. Karin, 90 år, sade: "Ja, jag är med i tusen föreningar och jag är med därför att då har man möjlighet att komma in och få se saker och ting som man inte får se som enskild individ. Så då är det värt att vara med i någonting. Det kanske var fler föreningar. Det här var ett litet axplock av dem". Det som jag diskuterar i följande avsnitt är: Vad innebar tidshorisonten på visst avstånd för de intervjuade? De teman som framkom i analysen var - vecko- och månadsaktiviteterna understryks - det är mycket som ska hinnas med - det sociala och offentliga rummet.

\section{Vecko- och månadsaktiviteterna understryks}

Ett resonemang som återkom i de intervjuades berättelser handlade om deras upplevelse av att den kvarvarande tiden löpte över veckor och månader. Det var framförallt de återkommande vecko- och månadsaktiviteterna som omnämndes, och inte sällan var deras kalendrar fullbokade med aktiviteter: "När man har så pass mycket engagemang så blir ju almanackan lite krävande på något sätt". Olga, 85 år, framhöll att detta engagemang handlade om liv och död: "Att jag har en del av mina uppdrag kvar för att de håller mig vid liv". Aktiviteterna ansågs alltså som "jäkligt meningsfulla och de tar mycket av min tid alltså". Det tycktes ofta handla om väl övervägda och planerade aktiviteter som de under inga 
omständigheter ville vara utan. De intervjuade planerade fysiska och sociala aktiviteter av olika slag, veckovis och månadsvis. Dessa skulle stimulera både kropp och själ. Flera gav uttryck för att de mådde bra av dessa aktiviteter i dag och förutsatte att det inte skulle bli annorlunda framöver: "Så därför måste jag hålla mig i gång så mycket som jag kan". Gerd, 70 år, nämnde att det var viktigt för henne att sköta om sin kropp och hålla sig frisk med hjälp av olika aktiviteter för att orka med livets begivenheter. Någon påpekade att det var hans eget ansvar att hålla sig aktiv: "Jag har också ett ansvar inför mina barn att vara i skaplig trim och inte bli [något] paket och ...". Även Bertil, 84 år, och Hilma, 76 år, underströk vikten av att aktivera sig:

Och sedan är det ju det att jag håller ju i gång väldigt mycket, jag går ju i snitt en mil om dagen. Och det är väl inte många 84-åringar som gör det. /.../ Helst är jag ute i naturen och det är min medicin. Den enda medicin jag har så är det mina promenader, en mil om dagen. Några piller har jag inte, tack och lov...

Så att bli äldre det blir vi ju alla, det kan vi inte komma ifrån, men att bli gammal väldigt fort, det har man ju möjlighet att stoppa om man är aktiv. Så att den möjligheten finns och det finns ju så himla mycket möjligheter. Om man vill.

Fred, 77 år, menade att de inplanerade veckoaktiviteterna hade flera syften (jfr Gunnarsson, 2013). Efter att ha resonerat lite kring hur de intellektuella och mentala behoven skulle stimuleras, så övergick han till de fysiska behoven och avslutade med vilka konsekvenser ett aktivt respektive mindre aktivt framtida leverne kunde få:

Och så måste man intressera sig för saker, tror jag, det är också väldigt viktigt, gör man inte det så faller man snart ihop. Man måste helst ha en hobby, så man håller sig fräsch i skallen, det kan vara vad som helst, man kan samla frimärken eller vad tusan som helst bara man har någonting att göra. För när man blir pensionär så är väl det svåraste att inte sjunka ihop och ligga på sofflocket hela dagarna och inte ha något intresse. Det är livsfarligt tror jag, då blir man gammal snabbt och då dör man snabbt alltså. /.../ utom det är det alltså hjärngymnastiken som är viktig, för att hålla sig både frisk och alert alltså, och det tror jag man måste göra. /.../

Citatet ovan illustrerar eventuella följder av att som äldre underlåta att aktivera sig. Hans, 77 år, nämnde att hans syskon hade blivit allt mer skröpliga och han konstaterade att en anledning till detta faktum var att: "Lite kanske de har att skylla sig själva, de har inte hållit igång kroppen riktigt, så bra...". 


\section{Det är mycket som ska hinnas med}

Detta resonemang kring den kvarvarande tiden handlade om inbokade rutiner som regelbundet återkom varje vecka, ett par gånger i månaden eller ett par gånger om året. Det var mycket som skulle hinnas med. Det kunde exempelvis handla om stavgång, simning, naturupplevelser, PROmöten, syjunta, kyrkobesök, musik- och konstupplevelser, etcetera. Framförallt det sociala samspelet med andra människor framhölls i denna dimension av den kvarvarande tiden. Att få utöva dessa aktiviteter med andra människor föreföll vara betydelsefullt. Det skedde i form av ett aktivt deltagande i civilsamhället - man var medlem och/eller utförde ideellt arbete (betalt eller obetalt) i idrottsföreningar, religiösa föreningar, stiftelser, ekonomiska föreningar, politiska partier, syföreningar, IOGT-NTO, Folkets hus, grannsamverkan, miljö- och välgörenhetsinriktade organisationer eller utövade informellt omsorgsarbete på äldreboenden och hos anhöriga, eller umgicks i de småskaliga nätverken eller hade regelbundna kontakter med familjen, anhöriga och vänner (jfr Jeppsson Grassman, 2005, s. 282). Frida, 72 år, framhöll betydelsen av sitt lilla nätverk och dess engagemang i kulturlivet:

Och då tänkte jag, vilka krutkärringar. För vi har ju såklart våra krämpor men vi träffas och vi kan inte tänka oss att liksom bara sitta och snattra, ja, det låter ju så negativt, för det gör vi så klart också. Men vi måste göra någon kultur, vi måste liksom iväg på någonting, så vi får en upplevelse tillsammans /.../ så vi var på Nordiska museet och tittade på klädedräkten /.../ trevligt var det och roligt var det. Vi såg en bild där, där vi stod allihop tyckte vi, på 50-talet då i våra kjolar och allt det där.

Hans, 77 år, påpekade vikten av umgänget med andra människor framför "ensamaktiviteter":

Jag tycker ju att det är viktigt att hålla igång med meningsfulla uppgifter. Att bara sätta sig ned vid TV:n eller möjligen korsord och så vidare, det är inget ont i det men jag vill ha lite annat också. Och hittills har jag utrymme för det. /.../ Men jag hade ju hyfsat bra kontaktnät så att det genererade ju naturligtvis en hel del. Jag är ju inte kommersiellt inriktad utan jag har ju varit mer ideellt inriktad i det jag har sysslat med. Ja, här i Stockholm finns det ju ett fantastiskt utbud av möjligheter alltså.

Just de regelbundna kontakterna med familjen, anhöriga och vänner framhölls som betydelsefulla. Att få träffa och umgås med barn och barnbarn i veckorna eller få träffa dem vid de återkommande söndagsmiddagarna ansågs som en ynnest och som något som satte guldkant på tillvaron. När anhöriga, och även vännerna, omnämndes i dessa samman- 
hang handlade det ytterst sällan om någon beroendeställning, utan snarare om ömsesidiga relationer. Hans, 77 år, menade:

\begin{abstract}
Ja, jag har det ju väl tillgodosett på det sättet att mina barn finns här i Stockholmstrakten, allihop /.../ och det gör ju att det finns en ganska stor familj i närheten. /.../ Ja, jag kanske inte kan karaktäriseras som extremt aktiv i det avseendet men jag tycker det är väldigt viktigt [med familj] och har stor glädje av det. /.../ Ja, ja vi har haft en hyfsad familjesammanhållning, det tycker jag, men nu är det ju speciellt intensivt när det gäller mitt barn nummer tre som har tre döttrar, /.../ och de hämtar jag ju på dagis två gånger i veckan i regel så att där har jag ju väldigt nära kontakter.
\end{abstract}

Flertalet framhävde alltså betydelsen av familjen och släkten. Vare sig det rörde andra, tredje eller fjärde generationen, så förblev den generationsöverskridande gemenskapen viktig och förhoppningen var att så skulle den förbli i framtiden.

\title{
Det sociala och offentliga rummet
}

När de intervjuade berättade om detta förhållningssätt till den återstående tiden så tycktes tiden ofta förankras rumsligt och materiellt utanför hemmets väggar. Hilma, 76 år, framhöll:

Men om man vill vara aktiv så måste man ju gå utanför sina dörrar. Det är ju bara det som är - man har inte möjlighet att ha något sällskapsliv i större omfattning i sitt eget hem, utom med sina släktingar om de hinner vara hos mig så mycket, de har sina egna liv.

Framtiden, den aktiva framtiden, utspelade sig utanför hemmet - i naturen, på offentliga platser, i föreningslokaler och i församlingshem eller hemma hos vänner och släktingar. Karin, 90 år, konstaterade att veckorna framöver var fullbokade med aktiviteter som var utspridda över ett stort aktivitetsområde:

Ja, det är jäktigt, ja det är jäktigt, man har så mycket att göra, som ska hinnas. Så inga ensamma stunder här inte, nej. Det är det inte. Nästa vecka har jag en dag när jag har fyra grejer samma dag, så du hör. Ja, just det. Vi träffas klockan 10 varje måndag och sedan är vi ute och går. Träffas klockan 10 och brukar komma hem vid halv två. Går vi och tittar på någonting, alltså promenerar tre, fyra, fem kilometer ibland så där, tittar på någonting vad som helst. Och tisdagar, som sagt var, går jag alltid på läkarsällskapet på kvällen och har föreläsning och så sitter man och superar runt där. Och onsdagar går jag på Röda Korset, där var jag på, som jag säger, "knuff och drag", du vet, ja, styrketräning, man gör så här [visar med armar och ben]. 
/.../ Ja, och sedan vattengymnastik. Och torsdagar - allt det här är saker som jag har ordinarie - då har vi en studiegrupp om församlingens historia, ja, ja. Fredagar kanske inte är något som är veckovis återkommande, men det, ja...

David, 73 år, berättade också om allt som upptog hans tid. Han var en av dem som underströk vikten av att förankra sitt engagemang på den lokala samhällsnivån och som värnade om en levande framtid för landsbygdsorterna. Till stora delar verkade hans engagemang förknippas geografiskt med landsbygdsorten. David nämnde:

Vi har en lokal pensionärsförening här i Småland, som inte är anknuten till PRO eller SPF eller RPG eller vad de heter, utan det är lokalt här och huvudsyftet är gemenskap /.../ som träffas och läser tillsammans. /.../ Vi är engagerade i, varje onsdag, så gott som varje onsdag så brukar vi vara med och träffa invandrare. I samhället här finns ett antal somaliska flyktingar, som har kommit hit och som vi träffar och samtalar med, en gång i veckan.

Det som framhölls var alltså inte bara att intervjupersonerna hade ett intresse av att få utöva dessa aktiviteter, utan det var även den gemenskap runt aktiviteterna som tycktes skapa mening för dem. Det handlade om att ha möjlighet att upprätthålla en identitet och få känna tillhörighet, att ha möjlighet att känna sig behövd och få synas i offentliga sammanhang. Det handlade om en gemenskap de upplevde i nuet, och som även kunde bestå in i framtiden. Detta förhållningssätt till den kvarvarande tiden upplevdes sålunda i de flesta fall som positivt, och omnämndes som ett slags kvalitativt och relationellt framtidsperspektiv. Det föreföll också existera ett slags "det ordnar sig alltid mentalitet", där kollektivet hjälpte till om det behövdes. Essentiellt var alltså meningsfulla aktiviteter för kropp och själ som genomfördes i samspel med andra människor utspridda på offentliga platser, i privata hem, i naturen, etcetera. En relativt rörlig kropp och kognitiv förmåga tycktes vara det som möjliggjorde detta engagemang.

\section{Tidshorisonten ganska långt borta}

Ett tredje mönstret framkom i berättelserna - att den kvarvarande tiden tidsmässigt kunde beröra flera år. De intervjuade beskrev ibland den kvarvarande tiden som väldigt elastisk och näst intill obegränsad. Det rörde sig alltså om en återstående tid som varken var här och nu eller ett par veckor, månader eller ett halvår bort. I stället handlade det om ett tidsperspektiv som tidsmässigt och rumsligt i vissa fall sträckte sig mycket långt bort (jfr Clarke \& Warren, 2007, s. 472ff). De framhöll exempelvis: "Att få ha kul många år till, det ser jag fram emot", "jag ska leva länge, 
länge, länge", "jag håller på så länge det går", "jag är inte klar med detta än på ett tag", "jag ska utveckla mig väldigt mycket, både mentalt och andra saker". Med utgångspunkt i de sammanhang som dessa citat nämndes gick det ofta att utläsa att tidshorisonten placerades ganska långt bort. Det handlade många gånger om förhoppningar om att bli så och så gammal, hinna med det och det, etcetera. Ett annat exempel på detta mönster, som i flera intervjuer dök upp spontant utan att jag ställt några frågor om det, gällde funderingar på hur gammal man kunde hoppas på att bli. Hilma, 76 år, och Jenny, 85 år, berättade:

H: Ja, nu är jag 76 så nu tänker jag bli 95.

M: 95, m.m., m.m.

H: Ja eller 100. Om hälsan håller. Mina närmaste säger: "Jo, farmor ska bli 100 år". Ja, så jag får se.

Man kan ju säga så här att man vill leva så länge som man njuter av livet, har glädje av livet och så gammal vill jag bli. Brukar skoja, andra säger - Du blir 100-150! - Nej det tror jag inte, men jag vill kunna ta del av livet i alla dess olika faser! Att kunna vara så klar och så frisk att jag kan göra det. Sedan om det blir till 90-års ålder eller 95, det, jag lämnar det där hän. För det är inte avgörande den siffran, avgörande är min status. Och det önskar jag att den är så god så att jag kan ha någon glädje av livet.

I följande avsnitt diskuteras: Vad innebar tidshorisonten ganska långt borta för de intervjuade? De teman som framkom i min analys var - tidsmarkörer - att ha hög ålder $i$ generna - det finns en hel del kvar att uträtta - att hålla sig frisk, och oberoende.

\section{Tidsmarkörer}

Den kvarvarande tiden markerades ibland med tämligen exakta och tydliga tidsangivelser. Det var inte ovanligt att viktiga och betydelsefulla framtida händelser fick fungera som ett slags tidsmarkörer. De intervjuade nämnde exempelvis att de hade förhoppningar om att få uppleva ytterligare en ny generation se dagens ljus, få uppleva barnbarnets konfirmation eller studentexamen. De framhöll även den egna födelsedagen som exempel: "Jag tänkte stå ut till 90 år" och "det är en ganska kort period och sedan får vi ta det som det kommer". Ett annat inte ovanligt resonemang handlade om att det hade varit så trevligt att fira en jämn årsdag och nu såg man redan fram emot nästa jämna årsdag för att återigen få uppleva detta firande (jfr Clarke \& Warren, 2007, s. 474). En deltagare sade: 
För några år sedan så tänkte jag så här, jag tror inte jag vill bli mer än 90, tror jag inte. Sedan har jag en granne i huset här som fyllde 91 som går ut varenda dag och sköter sig själv och gör och gör och gör, ja, men kanske, kanske att man ändrar sig när man kommer dit. Samma som det här med, med födelsedagskalas. 80 tänkte jag då som final där. Nej, nu vart det 85 . Så det kanske, det kanske skjuter sig, jag vet inte...

Det föreföll som att dessa markörer utgjorde en bortre gräns som de levde för och hade förhoppningar om att få uppleva: "Ja, jag har tänkt så här, för 10 år sedan så tänkte jag - 10 år har jag ju säkert på mig! Nu tänker jag också 10 år framåt, det kan nog tänkas att jag har". Däremot förväntade de sig inte kunna påverka att målen förverkligades. Det tycktes även som att intervjupersonerna relaterade dessa markörer till den förflutna tiden. Upplevda födelsedagar, studentfester, barndop, etcetera, var erfarenheter med positiva avtryck i livet och som de gärna skulle vilja återuppleva. Frida, 72 år, nämnde att hon såg framemot att bli gammelmormor för hon kom ihåg hur lycklig hon blev när barnbarnen föddes:

Ja, det är ju det här att få vara frisk så länge som möjligt förstås. Det är ju A och $\mathrm{O}$ då, få uppleva barnen och allt det där, kanske barnbarnsbarn. Ian är ju ändå 18, man vet aldrig, ja fast han ska dröja ett tag, hoppas jag ...

Gerd, 70 år, berättade också om sina barnbarn och förhoppningen om att få uppleva den dagen när de tog studenten. Hon nämnde att det var någonting speciellt med att få vara med när någon tog studenten, men konstaterade samtidigt: "... det är ju om 9 år, det är nog något litet mål kanske, ja". Göte, 83 år, nämnde att han och hans fru tänkte kring framtiden i 5-årsperspektiv och föreföll nästan ta för givet att livet inte tog slut efter den perioden heller:

Vad kan man säga, när man ser framåt då vid 83 års ålder alltså, vi brukar väl faktiskt säga - Hur ser det ut för oss om 5 år? Ungefär i det perspektivet, pratar vi då med varandra. Hon har väl haft lite mera otur med hälsan än vad jag har så att säga, hon är väl kanske lite mera missmodig med tanke på framtiden men jag ser inte att livet ska ta slut i och för sig om 5 år, det tycker jag inte. /.../ Men det är klart att tar man det i ett 10-års perspektiv då blir det förmodligen annorlunda. För att är man över 90, och lever man till över 90 alltså, då måste det ju bli ganska stora inskränkningar i möjligheterna att överhuvudtaget kunna utföra eller leva ett någorlunda meningsfullt liv.

När intervjupersonerna framhöll detta tidsperspektiv - med dess utsatta tidsmarkörer - så tycktes tiden förankras rumsligt och materiellt i högtidliga tillställningar. De såg födelsekalas, födslar, dop, bröllop, etcetera, 
framför sig som utspelades i miljöer som väckte känslor av hopp och förtröstan. Alltså viktiga livsövergångar och ritualer som markerade kontinuitet och sammanhang och att livet gick vidare även om man så småningom skulle dö.

\section{Att ha hög ålder i generna}

Det var inte heller ovanligt att intervjupersonerna gjorde egna skattningar kring hur lång tid de kanske hade kvar här i livet genom att dra paralleller till hur gamla deras anhöriga hade blivit. Hade de haft föräldrar eller nära släktingar som hade levt länge och blivit drygt 90 år, fanns en förhoppning om att de själva skulle nå en sådan aktningsvärd ålder. Nora, 76 år, konstaterade:

Ja, eftersom min pappa i stort sett blev, få se nu, han blev 90 och mamma blev 94, så är det på något sätt, det är där framme någonstans. Och ja, bortsett från släktingar som har gått bort väldigt unga, mellan 30-40 år, så har alla blivit upp i de åren, så att jag har på något sätt tänkt mig att det, det blir väl så [småskrattar]...

I dessa resonemang begrundades också hur livet hade gestaltats för de nära anhöriga - "men de har ju levt under andra betingelser". Att de anhöriga levt under den tidens förhållanden och trots det blivit så gamla, var något intervjupersonerna förundrades över - "och varför inte jag också". I samband med denna jämförelse uppstod det inte sällan funderingar kring det biologiska arvet. Föräldrar eller anhöriga som hade dött en alldeles för tidigt död i exempelvis cancer, alzheimer eller hjärtinfarkt kunde ibland föranleda tankar kring generna. De började fundera över det genetiska arvet och hur detta kanske skulle komma att påverka. Hans, 77 år, konstaterade, även om han kanske inte till varje pris ville bli lika gammal som sin mor, att:

Ja, när man har kommit upp i min ålder, så måste man ju inse att det inte är så jäkla lång tid kvar. Även om den relativt sett kan bli rätt lång så är det ju inte så himla många år. Det är inte möjligt, och de gener jag har är av två slag kan man säga. Min far dog ung, 50 år, min mor, 101. Så jag vet inte, troligen så är det mest min mor, som ligger i mina gener... Nej, det är ju inget att sträva efter, att bli väldigt gammal. För min mor så var det så att hon hängde rätt bra med till hon var 97, skulle jag säga, 95, 96, 97, där någonstans börja det vända. De där följande åren var ju inte särskilt meningsfulla. Så, det där kan man ju inte reglera särskilt lätt men att det inte ska bli alltför lång period av innehållslöshet och maktlöshet och där skiljer sig inte min åsikt från, skulle jag väl påstå, alla andra... 
Arne, 86 år, förde också ett resonemang kring föräldrarnas livslängd, men inkluderade även sin gamla bil i denna beräkning av den möjliga kvarvarande tiden:

När min mamma gick bort - min pappa var bara 52 år vet du, det var lite tidigt. Jag gick ju och tänkte på det där, om en annan hade de anlagen... Men mamma hon dog väl av... hon var ju gammal ... 88 eller någonting sådant. Hon blev förkyld och så tog det bara några dagar så där /.../ Jag lever ju kanske i farozonen lite grann, har jag tänkt på. Jag tänkte stå ut till 90 år, det till att börja med, och att bilen ska räcka. Jag tror inte bilen räcker längre. /.../

Detta synsätt på framtiden medförde en del spekulationer bland intervjupersonerna. De vägde fördelar mot nackdelar, de räknade på hur många år de kanske hade kvar. Risken att ha ärvt någon släktings sjukdom räknades fram med hjälp av en procentsats. I kalkyler togs hänsyn till tidigare erfarenheter, som fick vägleda deras förhoppningar inför framtiden. Andra gånger, påhejade av sina anhöriga: "Jo, farmor ska bli 100 år" och "Du blir 100-150". Intervjupersonerna verkade emellertid göra dessa uppskattningar av tid kvar med glimten i ögat och med humor: "Så är jag frisk, gudskelov, inga sjukdomar, och det kan man ju vara tacksam för ... sina gener".

\section{Det finns en hel del kvar att uträtta}

De intervjuade ansåg att det fanns en hel del kvar att uträtta i livet. Det handlade om drömmar och ännu inte genomförda planer:

Jag planerar nog ungefär lika som tidigare tror jag. /.../ Ja, men då tänkte man i alla fall annorlunda för då hade man all evighet i världen på sig och det har man inte längre utan trots allt, så är det en tidsbegränsning. Får jag vara med så länge? Får jag vara med en bit till?

Det tycktes som att planer och drömmar inför framtiden var väsentliga för både kropp och själ: "Men just det här att man hela tiden har någonting, nya saker och planerar nya saker i tankarna, och sedan försöker att plantera dem någonstans och kolla, är det här möjligt och kan vi göra så här, så jag tror att det håller ändå hjärnan igång".

Till skillnad från de aktiviteter som rutinmässigt skulle hinnas med vecko- och månadsvis, så handlade det här snarare om projekt som tog mer tid i anspråk. Hans, 77 år, nämnde: "Ja, jag har en del projekt igång nu, och det är mest författande. /.../ Så det är väl de lite större grejerna som jag hoppas kunna genomföra, men jag vet inte om det går...". Han hade åtagit sig att delta i ett projekt för att skriva en slags krönika över ett före- 
tags handel och vandel. Många nämnde även resor som aldrig blev av och som nu förväntades bli av - " Och en liten resa till Gran Canaria kunde väl vara en önskedröm att få göra". Fred, 77 år, nämnde att han och frun hade lite resplaner på gång och Hilma, 76 år, berättade om sin dröm:

F: Vi har mera planer på sticka ut och resa och sådant där.

M: Mm, är det mycket, är det mycket framtidsplaner eller?

F: Resa ja, ja den närmaste tiden här har vi planer på att sticka iväg alltså.

Ja, jag skulle vilja hinna med att sjunga in en skiva. Men jag vet inte om jag klarar av det. Jo, sångmässigt klarar jag men det här praktiska, allt det där så jag måste hitta på någon som gör inspelningen och sådant där.

Deras uttryck för att det fanns en hel del kvar att uträtta - förankrade tiden rumsligt i ett ganska vitt och brett landskap som hela tiden föreföll uppträda utan fasta konturer. Ett möjligheternas landskap tycktes alltså ligga framför de intervjuade där tidshorisonten placerades ganska långt bort. Den kvarvarande tiden kunde således omfatta många år.

\section{Att hålla sig frisk}

Att kunna se framtiden an med tillförsikt var framförallt beroende av det framtida hälsoläget och hur man lyckades hålla sig "pigg". Frida, 72 år, menade: "Ja, det är ju det här att få vara frisk så länge som möjligt förstås. Det är A och O då". Även Fred, 77 år, menade: "Det är det vi försöker förebygga genom att sköta oss, så bra som möjligt". Visst fanns där en oro för vad en försämrad hälsa skulle kunna betyda för framtiden: "Samtidigt ser vi ju, jag menar - krämporna kommer. Det är tyvärr så och då blir man ännu mera påmind om att det inte varar i evighet så att säga". Kände man sig relativt frisk för tillfället så kunde framtiden ses an med tillförsikt. Hans, 77 år, tydliggjorde att han var mentalt förberedd på att hälsan kunde försämras och att det kanske kunde ske omgående, men han upplevde det inte som så skrämmande just för stunden:

Ja, alltså man måste ju vara mentalt förberedd på att det kan hända saker, tvärt, som radikalt ändrar livsmöjligheterna. Det är jag rätt försonad med, den tanken att det kan hända och det får man försöka klara så gott det går men det är ju inget lockande perspektiv. Men jag går inte och är skrämd för det varje dag, det, det, absolut inte så.

Även Erik, 70 år, funderade på vad kommande hälsoproblem kunde få för konsekvenser för framtiden: 
Så att framtiden, som vi diskuterar ibland, lite allvarligare då, hur länge vi orkar ha det här stället. Vi är ju inställda på att vi kanske inte orkar, det beror ju på, någon av oss kan ju bli sjuk, så vi har ju det i bakhuvudet och vi har pratat om det - att är det så att inte någon pallar här, för då är det inget roligt längre, då säljer vi nog det här.

Det var inte enbart hälsan som omnämndes i detta sammanhang - "lusten att leva" spelade också en avgörande roll för att kunna se framtiden an med tillförsikt:

Jag brukar säga det till människor att så länge du har lust, så länge du har lusten, så kommer du att leva. Men försvinner den då kommer du successivt att försvinna. Det tror jag på till 100 procent. För den dagen jag inte känner någon lust att göra någonting, ja alltså det är bara min egen filosofi, men då tror jag att då är man färdig, då är det färdigt. Jag har inte kommit dit än.

För att exempelvis kunna säga att: "jag är inte klar med detta än på ett tag" - livet och den egna framtiden - krävdes alltså, att man vårdade sin hälsa och höll sig frisk. En avgörande faktor var "lusten att leva".

\section{Oberoende}

Väsentligt var - för att kunna blicka långt in i framtiden - att i möjligaste mån klara det vardagliga livet utan av hjälp från anhöriga, släktingar, vänner och hemtjänsten. En intervjuad konstaterade att oberoende var målet:

Jag vet att de kommer att ta hand om mig när det behövs. Men jag hoppas att jag inte behöver vara till belastning för dem. För det är ju liksom ingen framtid att man ska vara belastning för de sina, sina anhöriga, sina barn och barnbarn...

Att behöva uppta tid från anhöriga ansågs inte vara någon utväg (jfr Gunnarsson, 2009a; 2009b). Frida, 72 år, förde ett resonemang som berörde hennes ambivalenta inställning till att kanske behöva bli beroende av hjälp i framtiden från anhöriga eller kommun, något som också flertalet nämnde i sina berättelser: 
Ja, jag räknar ju med dem såklart [familjen], att de kommer att finnas där och att de bryr sig. Jag har ju inga stora konflikter som tur är. Jag har också både en bror och en syster, men jag vet hur det är, var och en har nog med sitt eget egentligen. Jag vill ju inte ha vård av mina nära, det vill jag inte. Jag vill inte bo hos dem till exempel eller vara en belastning, det är ju det sista man vill - vara en belastning. Så det kommer bli svårt för mig att ta emot hjälp, det känner jag ju, jag gör inte det nu heller. Men det blir man ju tvungen till naturligtvis, det är klart att den där dagen när den där handläggaren kommer och man ställer frågor och man har krav och hon säger bara att - det går inte - det blir inget roligt.

De intervjuade menade att för att kunna se framtiden an med tillförsikt, och med förhoppning om att kunna genomföra planer, och uppfylla drömmar, krävdes det också att den kvarvarande tiden inte kantades av ett beroende av andra människor.

\section{Sammanfattning}

I detta kapitel har jag fokuserat forskningsfrågan: Hur ser äldre människor på sin framtid och på den tid som är kvar? För de intervjuade utgjorde framtiden inte sällan ett centralt inslag i det vardagliga tänkandet. De funderade och hade åsikter om framtiden. Ett långt liv och en hög uppnådd ålder hindrade dem inte att fundera över den egna framtiden, och det fanns också en mening med framtiden. Det gällde vare sig man var 70, 80 eller 91 år. De här funderingarna på framtiden skapades och omskapades ständigt, de var då och då präglade av tidigare erfarenheter och de hade också olika utsträckning i det framtida tidrummet. Tre tidshorisonter identifierades. Vart och ett av dessa mönster kan sägas motsvara ett förhållningssätt till det framtida tidrummet - förhållningssätt som deltagarna kom att inta och pendla mellan under samtalen. För att enklare förklara och förstå och framförallt kunna särskilja dessa förhållningssätt, valde jag alltså att använda en horisontmetaforik där vart och ett av förhållningssätten motsvaras av en tidshorisontmetafor. Det som är viktigt att understryka är att samtliga tre tidshorisonters innebörd uppträdde/existerade parallellt och förmedlades mer eller mindre i var och en av de olika berättelserna:

Tidshorisonten här och nu - Detta förhållningssätt innebar att man upplevde att den kvarvarande tiden enbart handlade om den aktuella dagen, att man tog en dag i sänder. Man kopplade ofta tiden rumsligt till hemmets sfär där de vardagliga rutinerna betonades men där också upplevelsen av ensamheten gjorde sig gällande. Framtida projekt och drömmar tonades ner då det inte ansågs vara någon större idé att planera för man levde ju bara för dagen. 
Tidshorisonten på visst avstånd - Här innebar förhållningssättet att man upplevde att den kvarvarande tiden omfattade de framförvarande veckorna, månaderna eller halvåret. I större utsträckning förlades tiden rumsligt utanför hemmets sfär, men geografiskt ganska nära hemmet. Man betonade de återkommande aktiviteterna, livet och tillhörigheten till föreningslivet.

Tidshorisonten ganska långt borta - Detta förhållningssätt innebar att man upplevde den kvarvarande tiden som elastisk och ibland näst intill obegränsad. Det långa livet betonades, men även planer, projekt, förhoppningar och drömmar. Det var sådant man nästan förväntade sig och räknade med att få uppleva om man bara fick vara frisk.

De här resultaten som visar hur de intervjuade pendlade mellan parallella tidshorisonter, ger inget stöd för argumentet att äldre människors förhållningssätt till framtiden nödvändigtvis blir alltmer nutidsinriktat. 


\section{KAPITEL 9}

\section{Sammanfattande resultat och slutdiskussion}

Konsten att leva måste man fortfara att lära sig hela livet igenom, och - vad som kanske kan synas underligare - man måste under hela livet lära sig konsten att dö (Seneca d. y. 100-talet e. Kr.).

Filosofen Seneca menar att konsten att dö handlar om ett livslångt lärande, något som inte avslutas förrän döden inträder. Det har visserligen förflutit nästan två tusen år sedan detta yttrades, och man kan historiskt också se att konsten att lära sig att dö har skiftat under tidens gång (Ariés, 1978; Kellehear, 2007a; Walter, 1994), denna konst att dö är ständigt dagsaktuell. Ämnet för denna avhandling är äldres framtid, döende och död. Avsikten har varit att utifrån 27 relativt friska äldre människors - i åldern 70-91 år egna berättelser undersöka och förstå vilka föreställningar de hade om sin egen framtid, döende och död. För att kunna analysera och förstå hur de intervjuade hanterade vetskapen om döden har ett livsloppsperspektiv använts, där hela deras livslopp - dåtid, nutid och framtid - har tagits i beaktande.

För att utforska de intervjuades föreställningar om den senare delen av livet, utgick studien ifrån deras egna erfarenheter, föreställningar och förhållningssätt. Genom öppna, kvalitativa intervjuer som byggde på samtal mellan intervjupersonerna och forskaren skapades kunskap om de intervjuades föreställningar kring framtid, döende och död. Det övergripande syftet med studien var att utforska äldre människors föreställningar om och förhållningssätt till den egna framtiden, döendet och döden. Följande forskningsfrågor kom att undersökas: 
- Hur beskriver äldre människor sina tidigare erfarenheter av döende och död?

- Hur ser äldre människor på sitt eget döende och på sin egen död?

- Vilka erfarenheter har äldre människor av möten med döende och död i det vardagliga livet?

- Vilka föreställningar har äldre människor kring vad som kommer att ske efter den egna döden?

- Hur ser äldre människor på sin framtid och på den tid som är kvar?

Syftet med följande avsnitt är att sammanfatta olika mönster och diskutera kapitlens huvudresultat. Jag utgår ifrån ovan ställda forskningsfrågor och de resultat som har framkommit i kapitlen. Därefter kommer en slutdiskussion där jag diskuterar ett antal övergripande teman, som framstår som centrala i studien.

\section{Studiens övergripande resultat}

Något som tydligt har framkommit i analysen är att de intervjuades berättelser präglas av olikheter. Deras erfarenheter av döende och död, deras föreställningar om och förhållningssätt till den egna framtiden, döendet och döden innehåller kontraster på olika nivåer. En och samma intervjuperson kan uppvisa konstraterande mönster i den egna berättelsen liksom även intervjupersonernas berättelser kontrasterar varandra. Det är på de här mönstren jag bygger denna sammanfattning.

\section{Hur beskriver äldre människor sina tidigare erfarenheter av döende och död?}

I de intervjuades berättelser framkom minnen och erfarenheter av döende och död som både förenar och särskiljer. Det är möten med döende och död som inträffade vid olika tidpunkter i livet, som utspelades i olika sociala och kulturella miljöer och som knöt an till olika åldersrelaterade roller. De här minnena och erfarenheterna har också varit med och präglat dem och deras förhållningssätt till döden. Det går att urskilja några kontrasterande mönster i mötena med döende och död. Först och främst påminner dessa mönster om de av Walter (1994) konstruerade idealtyperna den traditionella, den moderna och den postmoderna - kring olika förhållningssätt till döende och död. Här kan man i de intervjuades biografier följa hur dödens platser har ändrat karaktär, vem/vilka som har ansvarat för till exempel begravning, vård av döende och hur döden hanterades 
genom tid och rum - alltså mönster vilka inte sällan var präglade av de samhälleliga förändringarna rörande döende och död över tid. Det handlar också om mönster som bryter mot dessa idealtyper, där de intervjuades biografier avviker från sociala och historiska förhållanden om döende och död över tid och rum. Hos några intervjuade framkom exempelvis att döden i hög grad hade varit frånvarande under stora delar av deras liv. Antingen hade de nästan inte alls några erfarenheter av döden eller också var döden något man inte pratade om, skyddades från eller undvek. Av olika skäl hade det varit ganska tyst kring döden. Hos andra intervjuade hade döden däremot varit närvarande i hög grad. Döden synliggjordes under uppväxtåren och de efterföljande åren, det var ett ämne man pratade om i vardagen och som inte gömdes undan. Av flera anledningar hade det alltså funnits en öppenhet gentemot ämnet döden i intervjupersonernas sociala omgivning.

\section{Hur ser äldre människor på sitt eget döende och på sin egen död?}

Här framkom framförallt två mönster. $\AA$ ena sidan handlar det om ett mönster som inbegriper begreppet "on time". Det vill säga, några intervjuade menade att nu var rätt tidpunkt i livet att fundera på döden, att inte undvika tankar på saknade döda anhöriga när sådana funderingar väcktes till liv av minnen, föremål och situationer i vardagen. I stället borde man låta sig påminnas om sin egen och andras dödlighet. Vidare ansåg de att det var rätt tidpunkt i livet att faktiskt praktiskt förbereda sig inför det egna döendet och döden. Denna praktiska förberedelse kunde komma till utryck på flera sätt, till exempel genom att dödsstäda, planera inför begravningen och fylla i Vita Arkivet. Det handlade mycket om ett behov av att fundera och själv ta ansvar för den egna döden, men också om att planera och skapa förutsättningar för ett värdigt avslut. $\AA$ andra sidan förekom också ett mönster som i stället handlar om begreppet "off time". Några intervjupersoner menade, närmare bestämt, att det inte var rätt tidpunkt i deras liv att tänka på döden eller att planera inför begravning, etcetera. Det låg inte i linje med deras biografiska schema eller deras "färdplan" att ha sådana tankar just nu. Att ha funderingar på döden eller att planera inför döden tillhörde inte den friska ålderdomen. Det var något som i stället tillhörde de sjuka, skröpliga och döende, alltså den livsfas som kategoriseras som "fjärde åldern". Dessutom förlitade de sig mer på att närstående skulle ta ansvar för begravningsgöromålen, vilket bland annat kom till uttryck i oviljan att fylla i Vita Arkivet. Det som däremot förenade samtliga intervjupersoner var viljan och önskan om att få fortsätta att leva. Det var alltså inte dags att dö nu, vare sig man ansåg att det var rätt tidpunkt i livet att faktiskt tänka på döden eller inte. På olika vis ville de intervjuade förmedla att döden tillhörde ålderdomen - den livs- 
loppsmässigt förväntade döden - men samtidigt ville de också understryka sin egna subjektiva förväntan att det inte var aktuellt att dö för just dem på ett tag.

\section{Vilka erfarenheter har äldre människor av möten med döende och död $i$ det vardagliga livet?}

Det fanns flera vardagliga situationer, möten och händelser som kunde väcka tankar och frågor kring döden, men som även kunde leda in på samtal med andra människor om döden. Platser som kyrkogårdar, äldreboende och media, väckte funderingar som rörde både den egna döden, andras död och döden som fenomen. När det gäller samtal med andra människor framkom ett par olika mönster. Några intervjupersoner framhöll betydelsen av att kunna prata om döden - både utifrån existentiella och "terapeutiska" behov men också utifrån mer praktiska/instrumentella överväganden. Andra intervjuade tonade i stället ned behovet av samtal om döden. De intervjuade, som underströk betydelsen av att få prata, samtalade med närstående men också med personer som de träffade $\mathrm{i}$ någon förening. Föreningslivet innebar samhörighet och engagemang, vilket många uppskattade. Även om livet prioriterades där, kunde föreningslivet emellanåt användas som en arena för existentiella funderingar kring döden. Att ibland kunna samtala om döden i vardagen ansåg många deltagare som värdefullt, men det byggde på att man hade tillit till dem man samtalade med. Betydelsen av samtal handlade emellertid inte enbart om existentiella och "terapeutiska" behov av att få samtala för att hantera känslor kring ett svårt ämne. Det handlade också om ett upplevt ansvar att berätta om de egna önskningarna inför livets slut. Det gällde alltså samtal av mera praktisk/instrumentell karaktär i syfte att vägleda närstående innan det kanske var för sent. Det kunde även handla om att planera tillsammans och skapa förutsättningar för ett värdigt avslut. Andra intervjuade menade i stället att döden borde tonas ned eller helt undvikas i umgänget med närstående för att inte störa och skada relationen med dem. Att mildra mötet med döden genom att visa känslor och att prata med andra, menade några, vara överflödigt. I vissa fall handlade det om bristen på tillit. Man kände inte varandra tillräckligt väl för att samtala om döden. Ibland fanns heller inte några skäl till att prata eller behov att grubbla över döden - speciellt inte när man kände sig frisk. Man behövde alltså inte vara öppen med döden varken praktiskt, existentiellt eller "terapeutiskt". Döden skulle man antingen bearbeta själv eller prata om när man själv var döende eller skröplig. 
Vilka föreställningar har äldre människor kring vad som kommer att ske efter den egna döden?

I analysen av temat "efter döden" framkom två centrala mönster: $i$ evighet och $i$ förgänglighet. Mönstren motsvarade inte enbart en viss grupp av de intervjuade. De speglade olika förhållningssätt till ett efter döden, vilka kunde komma till uttryck i en och samma berättelse. Mönstret "i evighet" hade flera innebörder som rörde både världsliga och andliga föreställningar. De världsliga föreställningarna om "i evighet" handlade om att de intervjuade började förbereda sig för en tid i framtiden som inte längre inkluderade dem själva, och om att hitta sätt att "förlänga livet" och få "evigt liv" - en önskan om det "förlängda livsloppet". Att "förlänga livet" och få "evigt liv" kunde gälla en önskan om att få en välbesökt och en oförglömlig begravning, eller så kunde det handla om gravplatsens estetik, en plats där närstående kunde minnas dem. Att "förlänga livet" kunde även handla om hur de intervjuade ville bli ihågkomna eller om vilka avtryck på eftervärlden de åstadkommit. Detta påminner om begreppet "symbolic immortality" (Vigilant \& Williamson, 2003, s. 173ff), och dess fokus på minnen och avtryck som lämnas till eftervärlden. De intervjuade ville förbli odödliga av både egoistiska och altruistiska skäl, men de var också rädda för att försvinna i det tysta. De andliga föreställningarna om " $i$ evighet" handlade om att de intervjuade menade att det fanns något slags liv efter döden, antingen utifrån kristna värderingar eller andra religiöst färgade eller andliga värderingar. Ett kontrasterande mönster var "i förgänglighet" och som rörde världsliga såväl som andliga föreställningar. De världsliga föreställningarna om "i förgänglighet" handlade om att de intervjuade knappast fann någon mening med ett efter döden. De hade inte några förhoppningar om att kunna "förlänga livet" och få "evigt liv", och därför förberedde man sig inte heller för en tid i framtiden som inte längre inkluderade dem själva - man investerade alltså inte i framtiden (Bauman, 1994) på det sättet för att få "evigt liv". Detta kom till uttryck dels genom att den egna begravningen tonades ner och dels genom att inte vilja ha en gravplats. Det kunde även handla om att de intervjuade inte ville bli ihågkomna, eller lämna några avtryck på eftervärlden. Anledningen till detta "i förgänglighet" var att "man var ju död då", och dessutom "skulle man ju snart vara bortglömd". De andliga föreställningarna om "i förgänglighet" handlade om att det inte fanns något slags liv efter döden: döden innebar det absoluta slutet. Det fanns alltså inte någonting bortom livet och de intervjuade menade att nya generationer tog vid när deras egen generation upphörde. 
Hur ser äldre människor på sin framtid och på den tid som är kvar?

Intervjupersonernas funderingar och agerande inför framtiden utgjorde ett centralt inslag i deras vardag. Möjligheten till framtiden var också något som de värdesatte. De hade åsikter om, planerade för och satte upp mål. De lade ner kraft och energi på att förverkliga planer och drömmar. I de intervjuades berättelser förmedlades en syn på framtiden som kan liknas vid ett flexibelt "tidrum", som ständigt vidgades och krympte ihop i takt med vad som avhandlades i berättelserna. Genom en och samma berättelse var alla tre tidshorisonterna närvarande, och en och samma intervjuperson pendlade mellan tidshorisonterna. Det handlade om en utsträckning i tiden som löpte från här och nu över veckor, månader till $\mathrm{i}$ vissa fall 10-15 år framåt $i$ tiden, och som rumsligt var kopplat till ett tänjbart rum som kunde röra hemmet, närområdet såväl som världen. Det var i de här berättelserna om framtiden som de intervjuade i ena sekunden menade att de hade en framtid, de planerade, de hade förväntningar om att bli så och så gamla, för att i nästa sekund tona ner förväntningarna, leva mer här och nu. Tidigare forskning (se Nurmi, 2005) förmedlar ofta en bild av att människor skulle bli mer nutidsorienterade, med tilltagande ålder, och att deras tankemönster rörande framtiden skulle förändras på grund av upplevelsen av en framtid som är mer begränsad nu än tidigare. De intervjuades syn på den egna framtiden visade sig dock vara mer komplex än så. Intervjupersonerna lät sig alltså inte fångas in i några biografiska scheman. Resultaten visar att den kvarvarande tiden var sammansatt och att de intervjuade laborerade med olika tidshorisonter. Denna laborering präglades av deras samlade erfarenheter och av deras förväntningar på framtiden just i nuet.

\section{Slutdiskussion}

Efter denna sammanfattning av kapitlens huvudresultat, kommer jag här till sist att diskutera några mer övergripande teman, som framstår som centrala i studien. Det är teman som handlar om en komplex bild av döende, död och framtid, åldersmönster, tredje åldern, det förlängda livsloppet, ansvar, kontroll och värdighet. De tillför på olika sätt, ytterligare förståelse kring äldres människors föreställningar om och förhållningssätt till den egna framtiden, döendet och döden. 


\section{En komplex bild av äldre människors föreställningar om det egna döendet och döden}

Syftet med studien har varit att utforska äldre människors föreställningar om och förhållningssätt till det egna döendet och döden. Det är ett forskningsområde som är underbeforskat, men också ett område präglat av stereotypa föreställningar och värderingar (se kapitel 1 och 2). En slutsats från studiens olika kapitel är att äldre människors föreställningar om och förhållningssätt till det egna döendet och döden både är komplexa och motsägelsefulla. Det vittnar inte minst deras minnen och erfarenheter tydligt om. De intervjuade har levt under en historisk tid där synen på döden undergått betydande förändringar (Ariés, 1978; Kellehear, 2007a; Walter, 1994). Det har också medfört att de i hög grad införlivat en ganska sammansatt bild av döden. Deras erfarenheter och minnen av döende och död var färgade av både traditionella, moderna och postmoderna förhållningssätt till döden (se kapitel 4). Hos några urskiljdes dock tydligt att en viss historisk tid av deras liv präglat dem mer än någon annan. Tydligast kom det till uttryck när det gällde tystnaden och öppenheten kring döden. Som en röd tråd genom några intervjuades liv gick det att följa hur döden distanserats, medan det hos andra livet igenom funnits en närhet till döden.

Dessa erfarenheter och minnen av döende och död har också haft betydelse för vilka förväntningar de intervjuade hade inför det egna döendet och döden. De parallella normsystem, som idealtyperna utgör, var också något de förhöll sig till när det egna döendet och döden diskuterades. I kapitel 5 och 6 framgick det särskilt tydligt att ålderdomen utgör den fas i livet då man börjar fundera och förbereda sig inför den egna döden, men även i någon mån börjar samtala om den. Detta ligger i linje med tidigare forskningsresultat (Rahm Hallberg, 2004), men också i linje med synen på det normala åldrandet. I denna förberedelsefas inför den egna döden gav de intervjuade ofta uttryck för en "postmodern" hållning till döende och död. Val och önskemål inför "den sista föreställningen" skulle spegla den egna personligheten (jfr Åkesson 1997) och beslut om detta skulle tas tillsammans med närstående (se kapitel 5 och 6). I motsats till denna hållning ansåg vissa intervjuade att den friska ålderdomen inte borde utgöra den fas i livet då man ska fundera på eller prata om döden. Förberedelsefasen inför döden, enligt detta synsätt, som mer bar spår av det moderna förhållningssättet till döden, tycktes i stället förläggas till framtiden - då man var skröplig eller döende.

För att återgå till Senecas citat så innebar konsten att dö för de intervjuade, att man antingen förberedde sig mentalt och praktiskt eller att man sköt förberedelserna på framtiden. Trots dessa olika synsätt på när 
det ansågs vara rätt tid att fundera på döden, gav samtliga intervjuade uttryck för att de ville leva, njuta av livet och se vad framtiden hade att erbjuda - det var alltså inte dags för just dem att dö än på en tid.

\section{En komplex bild av äldre människors föreställningar om den egna framtiden}

Syftet med studien har även varit att utforska äldre människors föreställningar om och förhållningssätt till den egna framtiden. Detta är ett område som är svagt beforskat inom socialgerontologin, och där den rådande bilden ofta är onyanserad (se kapitel 1 och 2). Samma sak gäller den forskning som anlägger ett livsloppsperspektiv - där ges sällan framtiden något utrymme. Om tidigare forskning kring äldre som utgått från livsloppsperspektivet ofta har uppehållit sig vid äldres levda liv och nutid, och visat marginellt intresse för äldres framtid, så visar den genomförda studien att livsloppet består av fler faser än - dåtid och nutid (jfr t.ex. Nilsson, Sarvimäki \& Ekman, 2003). En slutsats som kan dras från studiens kapitel är att äldre människors föreställningar om den egna framtiden både är komplexa och motsägelsefulla. Åldersnormer som därför enkelt kan avfärdas är att - äldres framtid enbart skulle handla om att man blir mer nutidsorienterad med åldern, eller att ålderdomen skulle karakteriseras av "agegraded socio-cultural structures that create predictable, socially recognized road maps for human lives" (Nurmi, 2005, s. 35). Mina resultat visar i stället att äldre människors funderingar och agerande inför framtiden utgör centrala inslag i deras vardag, den kvarvarande tiden är sammansatt och att de laborerar med olika tidshorisonter (jfr Nilsson, Sarvimäki \& Ekman, 2003). Men framtiden utgör också ett spänningsfält. Döden är en del av framtiden, något man kan förhålla sig till på olika vis, vilket kom till uttryck hos de intervjuade. De tycktes arbeta med parallella tidtabeller/ scenarier: dels pendlade de mellan de olika tidshorisonterna, dels införlivade de döden i vardagen eller sköt den på framtiden. I detta spänningsfält mellan livet och förgängligheten som framtiden utgör, fanns det intervjupersoner som samtidigt både dödsstädade och sade att de ville leva länge. Andra gav samma uttryck för en längtan att leva men försökte samtidigt hålla döden i schack genom att inte låta sådana tankar komma upp till ytan. 


\section{Åldersmönster}

En intressant fråga är om det fanns några synliga åldersmönster i de intervjuades förhållningssätt till den egna framtiden, döendet och döden. Enligt gängse normer i synen på åldrandet, utgör ålderdomen den livsfas då de flesta dör, det är också då äldre människor bör agera och förhålla sig till döden och det är dessutom då äldre inte längre antas ha någon framtid - heller inga planer och drömmar på grund av en allt mindre återstående tid kvar. Kronologiskt sett kan samtliga intervjupersoner i studien sägas befinna sig i den fas av livet som rubriceras som ålderdomen. Några, drygt en tredjedel av intervjupersonerna, hade passerat den statistiska medellivslängden med ett par eller flera år, det vill säga, 83,2 år för kvinnor och 79, 1 år för män. De hade också varit pensionärer under en lägre tid, mellan 15-25 år. De var födda under perioden år 1919-1930. Övriga intervjupersoner hade ett par eller flera år kvar innan de skulle nå medellivslängden, de var födda mellan åren 1931-1940 och hade varit pensionärer mellan 5-15 år. Med utgångspunkt både i de gängse normerna i synen på åldrandet och i det breda ålderspann, 70-91 år, som deltagarna i studien utgjorde, kan man fråga sig om det fanns tydliga åldersmönster i gruppen intervjuade, både kronologiskt och normativt. Det visade sig dock att så var inte fallet. I stor utsträckning handlade det snarare om en frånvaro av åldersmönster i de intervjuades utsagor. Mönstren, i de intervjuades funderingar och agerande inför framtiden, var komplexa och inte tydligt bundna till ålder. Oavsett om de var 70, 80 eller 91 år pendlade de intervjuade mellan de tre förhållningssätten - tidshorisonterna - när de berättade om sin syn på framtiden. Deras ålder eller den förmodade kvarvarande tidens utsträckning tycktes alltså inte spela någon roll för hur de funderade och agerade inför framtiden. Däremot förkom andra förhållanden som hade betydelse för deras syn på framtiden. Bland annat nämnde vissa intervjuade vikten av att även i framtiden ha nära sociala relationer med anhöriga, vänner och föreningsmänniskor. Några hänvisade till de anhörigas gener och hade förhoppningar om att uppnå samma ålder. Flera menade också att de hade en hel del kvar att uträtta, vilket också gällde de "spår" man önskade lämna efter sig - på vilka sätt man "eftersträvade odödlighet" (Bauman, 1994, s. 69). Vare sig de var 70 eller 91 år så ville man efterlämna avtryck på eftervärlden och bli ihågkommen. Detsamma gällde huruvida man funderade till vardags på döende och död. Bland dem som tänkte på döden till vardags fanns både de som var yngre och de som var äldre. Denna frånvaro av åldersmönster gällde även dem som bedömde att den livsfas de befann sig i inte var "on time" för att tänka på döden. Det fanns således andra faktorer än en åldersmässig anpassning till det "normala" livsloppet som hade betydelse för hur man förhöll sig till 
framtid, döende och död.

\section{Tredje åldern}

Ett viktigt resultat i denna studie som får betydelse för forskning om "tredje åldern", handlar om att relativt friska äldre människor i åldrarna 70-91 år, så kallade "tredje åldrare", faktiskt ägnar tid åt att planera inför, fundera på och prata om det egna döendet och döden. I tidigare forskning om tredje åldern har tystnaden kring döende och död varit påtaglig (Johnson, 2009; Wong, 1998; 2000). På något vis förmedlar denna forskning en bild av att livet i tredje åldern, vilket ofta beskrivs som att man ska vara aktiv, oberoende och handlingskraftig (Gynnerstedt, 2011, s. 189ff ), inte bör inkludera temat döden - den "dödsfria tredje åldern". Det tycks finnas en implicit uppfattning bland forskare om vad som bör studeras i tredje respektive i fjärde åldern, men också en tydlig uppfattning om vad det innebär att vara tredje åldrare respektive fjärde åldrare ${ }^{15}$. De här begreppen döljer att livet på många sätt är ett kontinuum, alltså en pågående process där man inte från den ena dagen till den andra byter från ett tredje till ett fjärde åldernliv. Det finns alltså en tydlig rågång mellan dessa forskningsområden, där döende och död definitivt tillskrivs fjärde åldern. Min studie bidrar till att göra denna skiljelinje mindre tydlig. Döden finns i högsta grad med i livet både i tredje åldern och i fjärde åldern. Att vara aktiv och eftersträva självförverkligande kan också innebära att ta ansvar och kontroll över den egna döden för äldre människor. De här resultaten stöder viss tidigare forskning där det framkom att aktivt åldrande också kan handla om att ta ställning till frågor och val som rör den egna döden (Clarke \& Warrant, 2007; jfr Wong, 1998; 2000). Mina resultat avviker dock något från Howarths $(1998 ; 2007)$ resultat. Analysen i hennes studie visade att relativt friska och hemmaboende äldre människor nästan aldrig funderade på eller pratade om döende och död, och att de fann skäl att skjuta funderingar på döden framför sig. Den slutsats Howarth drar är att om äldre människor knappast har några erfarenheter, förväntningar eller kunskap om döende och död medför det att de inte har någon kunskap om "how to die". Men mina resultat visar i stället att detta är mycket mer komplext och mångfacetterat. Att förena temat döden med begreppet tredje åldern synliggör åldrandets mångfald. Bortom kategoriseringarna av tredje och fjärde åldern skapar studien också förutsättningar för att kunna förstå att livet är en pågående process.

\footnotetext{
${ }^{15}$ Se t.ex. Taghizadeh Larssons (2011) forskning som visar prov på en nyansering av denna dikotoma uppdelning: att hjälpbehövande ålderspensionärer kan anamma en tredje-ålder-lik livsstil; se även Wong, (1998, 2000).
} 


\section{Det förlängda livsloppet}

Den genomförda studien visar att det är fruktbart att väva samman framtid med dåtid och nutid om man vill förstå äldre människors funderingar på det egna döendet och döden här och nu och inför framtiden. Studiens resultat visar också att "livet efter döden" i hög grad finns med i skapandet av livsloppet - ett livslopp som sträcker sig efter döden. De intervjuade har på skilda vis resonerat kring detta "förlängda liv" eller "eviga liv" och dess utsträckning i tid efter den egna döden (se kapitel 7). Vid studier av frågor om döende och död finns det anledning att utvidga livsloppsperspektivet till att även gälla dimensionen "efter döden" för att förstå de äldres funderingar på den egna döden. De olika livsfaserna under de intervjuades livslopp går således inte att isolera och förstå var och en för sig - de måste förstås tillsammans.

Ett viktigt resultat som kan bidra till att utveckla kunskapen om åldrandet inom socialgerontologin, för att kunna tolka och förstå äldre människors syn och förhållningssätt till den egna framtiden, döendet och döden, handlar om att även "tiden" efter det levda livet bör beaktas. Man måste se till det utvidgade livsloppsperspektivet - inte enbart utforska den tid som sträcker sig "från vaggan till graven" (Öberg, 2002, s. 44).

\section{Ansvar}

Ansvar är ett centralt, underliggande tema i de intervjuades berättelser, det är en slutsats jag drar. Måste människan ta ansvar för och förbereda den egna döden, eller går det att komma oförberedd och i stället överlåta detta ansvar på någon annan, till exempel de efterlevande? Det är en fråga som genomsyrar intervjuerna. Utifrån de intervjuades erfarenheter och minnen av döende och död är det inte svårt att konstatera att ansvarat för döden har förändrats under de intervjuades liv (se kapitel 4). I deras barndom handlade det mycket om att följa traditioner och att familjen, släktingar och vänner - kollektivet - skulle ha ansvar för döende och döda. Längre fram i livet, menade de intervjuade, hade ansvaret i stället fördelats mellan experterna och dem själva. Experternas ansvar hade dock oftast endast haft giltighet innanför institutionens väggar. Intervjupersonerna hade upplevt att de själva ansvarade för allt kringarbete vid närståendes död. I och med att döden tonades ned och ofta gömdes undan på institutioner syntes man inte heller kunna förbereda sig inför döden i samma utsträckning som tidigare. Men under de allra senaste åren tycktes åter förändringar ha skett - ansvaret för döden och dess förberedelser hade i större utsträckning kommit att vila på individen själv eller tillsammans med någon anhörig. Experterna hade inte längre samma dominerande roll. 
I de intervjuades funderingar kring det egna döendet och döden fick ansvarsfrågan också stort utrymme. Frågan hade olika dimensioner. Några menade att ansvaret vilade på dem själva eller tillsammans med närstående - ett gemensamt ansvar - det ansågs också oansvarigt att inte själv ta itu med planering inför både den egna döden och det "förlängda livet" (se kapitel 5, 6 och 7; jfr Clarke \& Warren, 2007). De tog, kan man säga, ansvar för sin valfrihet. Andra intervjuade menade i stället att ansvaret låg på de efterlevande, det var deras uppgift att ordna med begravningsgöromål och gravplats. De ville snarare få överlämna ansvaret på andra - ta sina händer från detta med döden. Några intervjuade kände däremot krav framförallt från omgivningen att själva ta ansvar för gravplats och den egna begravningen, även om det inte kändes aktuellt ännu. Långt innan de befann sig på dödsbädden kände de sålunda en press att ta ansvar för sin egen död. Denna press som några av de intervjuade gav uttryck för knyter an till valfrihetens ideologi (Walter, 2013), vilket innebär att människor helst bör vara förberedda inför sitt eget döende och sin egen död genom att planera inför döden, informera anhöriga om sina val, samtala med närstående. Walter anser att detta med att vara preparerad inför den egna döden har mynnat ut i ett slags mani kring döden - val till varje pris (Walter, 2013). I denna ideologis kölvatten tenderar andra viktiga ansvarsaspekter att försvinna - som den om att få känna trygghet inför livets sista tid. I själva verket, menar Walter, handlar människors funderingar många gånger om "the practice of care": Det viktiga för äldre människor är i stället att det överhuvudtaget finns adekvat vård och omsorg att få $i$ livets slut. Ett par intervjuade i denna studie gav uttryck för något som ligger i linje med detta resonemang - Det fick bli som det blir med gravstenar och liknande. Det viktiga var i stället att få ha närstående vid sin sida och slippa dö ensam, och att få överlämna ansvaret och få en god vård och omsorg när livet är som skörast (se kapitel 5).

\section{Kontroll och värdighet}

Ett annat övergripande tema handlar om värdighet. Inom forskningsämnen som etik, hälso- och vårdvetenskap har värdighetsbegreppet diskuterats och problematiserats och är ständigt aktuellt, men samtidigt är begreppet omtvistat, svårdefinierat och har sällan givits någon tydlig innebörd (jfr Blennberger, 2005; Edlund, 2002; Nordenfelt, 2003; 2010). Även inom den tanatologiska forskningen har begreppet en central betydelse (se Lantz, 2010; Nuland, 1994; Sandman, 2001; Ternestedt, 1998; 2010), där exempelvis begreppet sätts samman med diskussionen kring döendet: "en värdig död", "en god död", "en anständig död", "en fridfull död", och där värdighet knyter an till begrepp som bevarad självbild, integritet, identitet, självaktning, självbestämmande, sociala relationer, 
etcetera (Ternestedt, 2010, s. 239). Vad är det då för värdighet de intervjuade pratade om? Att fundera på, men även agera inför, både den egna framtiden och den egna döden handlade mycket om att planera, att få någon slags kontroll, men också om att skapa förutsättningar för en värdig tid kvar och för ett värdigt avslut, visade analysen.

Flera sätt att tala om värdighet framkom i de intervjuades resonemang om tidigare erfarenheter genom livet av anhörigas döende och död (se kapitel 4). Det kunde handla om deras upplevelse av platsens värdighet där döden inträffade, hur man på ett värdigt sätt hanterade döende och döda människor, men även om upplevelsen av ovärdighet vid dessa möten med döende och död. Till exempel ansågs bristande värdighet drabba anhöriga som hade haft ett utdraget döende eller dött på ett ovärdigt sätt, liksom att begravningar inför tomma rader i kyrkan var ovärdigt för den döde och för de närmst sörjande. Andra exempel handlade om den brist på värdighet som ovårdade gravar innebar. Brist på värdighet förknippades också med den ensamma döden - att dö ensam utan några anhöriga hos sig. Detta var upplevelser som präglade deras förhållningssätt till döende och död, och som medförde att de ville skapa andra förutsättningar för ett eget värdigt avslut.

Att dödsstäda, det vill säga, städa undan varje kväll och ha kontroll så att det var rent och snyggt om döden skulle inträffa på natten, var ett sätt att upprätthålla och bevara värdighet och identitet. Värdigheten kunde också handla om att få ha nära och kära vid den egna dödsbädden, eller att planera inför en fin och värdig begravningsceremoni. Värdighet innebar också att försöka undvika det ovärdiga. Några intervjuade berättade att de hellre ville hamna i minneslunden än att få en gravplats som kanske skulle medföra merarbete för anhöriga och där risken fanns att graven inte skulle bli vårdad. För några intervjuade handlade värdigheten främst om livets slut: ett utdraget lidande och ett på andra sätt ovärdigt slut var något de var rädda för, då ville de hellre få hjälp att dö. Värdighetstemat gällde även framtiden. De intervjuade ville bli bemötta med värdighet den tid de hade kvar av livet. Att enbart ses som en resurskrävande belastning på det övriga samhället - det var inte värdigt. Men ett värdigt liv handlade också om att få bo i eget boende, att få ha goda relationer med närstående, känna sig behövd och känna tillhörighet med andra föreningsaktiva.

I denna studie är begreppet värdighet mångtydigt och det knyter an bland annat till människans strävan efter att ha kontroll. Men sammantaget handlar det om att upprätthålla och bevara värdighet och den personliga identiteten vare sig det gäller funderingar på den egna framtiden eller tankar kring det egna döendet och den egna döden. 
Den genomförda studien har gett varierande bilder av äldre människors föreställningar kring den egna framtiden, döendet och döden. För mig personligen har samtalen med intervjupersonerna bidragit till en förståelse av, men också en ödmjukhet inför, deras funderingar kring döende och död, och en insikt om att ålderdomen i högsta grad handlar om livet. Resultaten genomsyras av deltagarnas önskan om att få leva och att livet pågår fram till döden. Det är en i huvudsak positiv bild som förmedlas. Jag hoppas att avhandlingen ska kunna bidra till förståelser av äldre människors liv, också när det gäller livets sista skeden. 


\section{SUMMARY}

\section{Older people's future, dying and death}

The fact of mortality and how we deal with death appear to be central to how human beings form societies and how we go about our own lives. As human beings, we are aware of the fact of mortality. However, the ways in which we deal with this insight can vary depending on contingencies of time and space, among other things. One question which presents itself is how older people who are still relatively healthy deal with this insight towards the end of their life.

There are several reasons why we should study elderly people's thoughts and attitudes about death, dying and their own future. Neither social gerontology nor thanatology has placed much emphasis on how older people themselves view death and dying towards the end of their life. In a Swedish social, cultural and historical context, this discussion is also largely missing. At the same time, old age is regarded as a stage of life where death is more or less expected, at least statistically. Most people today live to advanced ages, implying a prolonged process towards death. The dying and death of elderly people is, however, an area characterized by stereotyped conceptions and values. A common idea is that older people are ready to die, after having lived a full life. It is also taken for granted that older people reflect more on death and dying. In modern societies, where there is increasing interest in end-of-life issues, people are expected to take responsibility for this last stage of life. It may seem paradoxical that human beings are aware of their own mortality but often live as if death were a distant phenomenon. Are older people really more preoccupied with thoughts of death and dying? Do they discuss the topic of death with other people? Likewise, another topic in social gerontology where little research has been conducted involves older people's thoughts about their future. Lifecourse studies on elderly people tend to focus on their life history and present-day life, rather than on the future ahead. However, the will to continue living is characteristic of most human beings who think about and plan for their future. Research on elderly people shows that older individuals often re-evaluate their plans and ambitions, and become more oriented towards the present. What do older people themselves say about their own future and the time they have left? 
This thesis adopts a lifecourse perspective, which means that the respondents' thoughts and reflections on dying, death and their own future are best understood in the light of the dynamics of their entire life past, present and future - and within the historical milieu in which the individuals live.

\section{Aim and research questions}

The overarching aim of this study is to investigate elderly people's thoughts and reflections about death, dying and their own future. The study takes as its starting point the respondents' own experiences, thoughts and understanding about later life. By adopting a lifecourse perspective, this study not only focuses on experiences in later life but also considers how these were shaped by past events in the lifecourse of the individual. A qualitative research method was used. Specifically, the study builds on interviews with 27 older women and men in Sweden between 70 and 91 years old. Their long life and advanced age imply that they have limited time left. During the period the interviews were conducted, all respondents were living in ordinary housing and regarded themselves as relatively healthy. In the interviews, they were given the opportunity to reflect and look back on their past, and to talk about ageing, the future, dying and death. The following research questions were investigated:

- How do older people describe their previous experiences on the subject of death and dying?

- What are older people's thoughts about their own mortality, and their own death?

- What experiences do older people have in their everyday lives which bring them closer to thinking about death and dying?

- How do older people talk about the time after their own death?

- How do older people regard their own future and the time they have left?

\section{Method and theoretical framework}

The study used a qualitative research design, particularly qualitative interviews. The qualitative interview is a way of generating knowledge and gaining insight into people's lives. Based on the aim of the study and taking previous research into account, I formulated four basic participant criteria. The first criterion was that respondents should be in relatively good health. This is in contrast to earlier studies where death and dying 
were researched among frail elderly people. The second criterion was that the respondents should live in ordinary housing, since previous research on the subject has focused on older people in care homes, hospices or special housing. Thirdly, I set an age criterion for 70 years old and over. The 27 respondents who were interviewed were between 70 and 91 years old in 2010. This lower limit of 70 years was set because I wanted the respondents to have distanced themselves to some extent from their working life. Fourthly, I aimed for representativeness with regard to gender and civil status / family situation. The respondents consisted of 15 women and 12 men. Differences in family situation and civil status varied. Some were married or cohabiting, others were widows or widowers, some were single and some were divorced. Some had children and grandchildren, while others did not.

Semi-structured interviews were conducted using an interview guide. A number of pre-determined themes and questions were addressed in the interviews, but respondents were free to discuss and develop these themes. The themes were as follows: looking back on life; everyday life; the future; thoughts and reflections about their own death and dying; what happens after death; death and dying in everyday life. The interviews were recorded, and lasted between an hour and two and a half hours. In my analysis of these interviews, I used an abductive research method from a hermeneutic tradition.

The theoretical framework for this study builds on perspectives and concepts which have specific relevance for the topic at hand. The lifecourse perspective is one of the starting points for the study, and this makes it different from other studies of its kind. Using this perspective involved trying to explore and understand the respondents' experiences, thoughts and concepts about death, dying and their future, in relation to their whole lifecourse. Their stories of experiences throughout their lives, which included their reaction to the deaths of others as well as social and historical changes, informed my interpretation of the interviews. It informed how I understood the informants' stories and projections about their own death and their understanding of dying (Jeppsson Grassman, 2005; Öberg, 2002). Later in the analysis process, other concepts were used to understand the results, such as space of experience, horizon of expectation (Koselleck, 2004) and quantitative and qualitative time (Lundmark, 1989). The Third Age (Laslett, 1989; 1994), which relates to the lifecourse perspective, also influenced the study design. In the study, I problematised the Third Age in relation to older people's views of death, dying and their own future. Other central concepts in this study are future, dying and death, and Walter's (1994) ideal types of death. These ideal types were helpful in understanding how perspectives about death have developed and changed historically. Some of 
these changes occurred during the respondents' lifetimes, while some ideal types can also be identified within the respondents' own stories. These concepts and perspectives appeared at different stages in my analysis, some as starting points and others as tools for interpretation. However, these theoretical frameworks did not determine the direction of the study, but were used as guides, in keeping with the abductive and hermeneutic method used.

\section{Results}

The empirical results of the study are presented in chapters 4 to 8 . These chapters are structured according to the central themes which emerged during the course of the analysis: encounters with dying and death throughout life; thoughts of dying and death in everyday life; talk about dying and death; after death and the time remaining.

\section{Chapter 4}

This chapter discusses the respondents' previous encounters with death and dying. Their accounts and memories of the death of others contained similarities as well as differences. These memories and experiences have also shaped their attitudes about death. Contrasting patterns could be identified. On the one hand, these patterns are reminiscent of Walter's (1994) ideal types of death: the traditional, modern and postmodern death. In the respondents' narratives, I was able to identify changes in the places where people died, who managed the practicalities of funerals and how the subject of death and dying was handled. These patterns were characterised by the social and historical milieu of the time. On the other hand, there were patterns which could not be considered within the context of Walter's ideal types. Some of the respondents reported that they had not had many encounters with death at all. This could mean they had not had much experience of the death of others, but could also mean that the people around them avoided talking about death. In other words, death was something to be concealed. The opposite was true for other respondents, who reported that they had encountered death quite often, for example in their youth or in everyday conversations with others. In these cases, death was out in the open. For various reasons, these respondents noted that people around them had a more open attitude to death and dying.

\section{Chapter 5}

This chapter deals with the respondents' thoughts and ideas about their own mortality and death. Two patterns were identified. On the one hand, 
death could more or less be seen as "timely". Some said, for example, that their old age was an appropriate time to ponder issues surrounding death. The fact that objects and situations in everyday life triggered memories of friends and relatives who had passed away was also regarded as something they expected. Places such as cemeteries and care homes, as well as exposure to the media, elicited thoughts about death and dying, in terms of their own death as well as the death of others. Furthermore, the respondents considered it an appropriate time to prepare for the practicalities involved in their own dying and death. Preparations could take various forms. For example, they could involve cleaning up and putting things away at night, planning for their own funeral or writing a will. These preparations seem to be related to an urge to take responsibility for their own death, and to be able to ensure their death was dignified. On the other hand, I also identified a pattern where thoughts of death were seen as "untimely". Some of the informants firmly believed this was not the right time to think about such things as their death and funeral. This included more than the idea of dying "too soon"; they saw no reason to include these events in their plans. Planning for death was seen as incompatible with active and healthy ageing. It was seen as an issue for the sick, frail and dying elderly, or those in what was considered to be "the fourth age". Furthermore, these respondents also expected their relatives to shoulder the responsibility for their funeral. One element common to all respondents was a wish to live long lives. Equally, they thought it was not yet time to die, even if others thought it was an appropriate time to think about death. The respondents expressed, in a number of different ways, how they thought old age was the appropriate time to die. Nonetheless, they underlined that it was not yet quite the time for them to die.

\section{Chapter 6}

This chapter deals with the respondents' experiences of talking to other people about death, and whether they thought it was important to talk about death at all. Two patterns emerged here. Some respondents underlined the need to talk about death in everyday life, and believed that talking about death was meaningful. Conversations about death could be with relatives, friends, or even within organisations in which they were involved. Civic involvement symbolised participation and unity with others, which they thought was important. In these civic organisations, the focus was more on living life than on death. Nevertheless, they could also be a forum for talking about existential issues and reflecting on death. In particular, these respondents saw themselves as belonging to the generation which was next in line to die, so it was easier to talk about death in these 
groups. On the one hand, talking about death seemed to involve a simple need to talk. On the other hand, talking about the subject also showed that they took responsibility for their own death by expressing their preferences for the last years of their life. For example, it was an opportunity to guide and inform their relatives about their preferences, before it was too late. Sometimes, they also involved others in this planning, to ensure a dignified death. Furthermore, the respondents talked about death so that they did not feel alone with their fears or anxieties about dying. Some respondents played down the importance of talking about death. These respondents thought that talking about the subject would only provoke negative feelings, such as fear and an awareness that their time was running out. Some said that conversations about death would only cause close relatives to worry, and they avoided talking about it to ensure a smooth relationship. They also avoided talking about death with their closest friends. They considered it pointless to talk about it while they still enjoyed good health. They did not think it necessary to speak openly to others about death, partly because they saw it as a personal issue and partly because they thought it an issue for those who were actually dying. They therefore saw no need to talk to others about their own thoughts and feelings on death.

\section{Chapter 7}

This chapter focuses on what the respondents thought would happen after their own death. When I analysed the topic "after death", I identified two themes: "permanence" and "transience". These themes did not correspond to particular participant groups. Rather, they represented different ways of looking at life after death, and they even varied within each interview. The theme "permanence" had both earthly and spiritual dimensions. The earthly dimension was that the respondents projected a time in the future where they would no longer exist, and thought of ways in which they would be remembered. For them, "extending life" or "eternal life" could imply having a good and memorable funeral attended by many friends, or thinking about the aesthetics of the gravestone so that friends and family would have a place to remember them. For these respondents, "extending life" meant that they would be remembered after death, or that they had made an impact. The concepts of being remembered and having an impact are also linked to "symbolic immortality". The respondents wished to be immortal in an egoistic or an altruistic sense, and were also afraid of "disappearing into silence". The spiritual dimension of "permanence" included the respondents' beliefs in a life after death, which could involve Christian beliefs but also other values. The contrasting theme "in transience" also had earthly and spiritual dimensions. Earthly dimensions of 
"transience" were expressed by respondents who thought that talking about after death bore no meaning at all. They believed neither in the thought of extending life, nor in eternal life, and did not seem to have any plans for the future which did not include them. They did not invest in future plans as a way of making themselves immortal, as other respondents did. They did not place so much emphasis on events such as their own funeral, or the choice of a last resting place. Some said they did not even want to be remembered after death, and had no interest in leaving a mark or impact for future generations. The respondents said that the reason behind this "transience" was the reality of their own death, and the reality that they would soon be forgotten. The spiritual dimension of "transience" was linked to a belief that there was no life after death, and that death was the absolute terminal point of life. There is nothing beyond death, but new generations of people replace the old.

\section{Chapter 8}

The last empirical chapter deals with the respondents' view of their own future and the time they had left. Central to their everyday lives was this relation to a future they valued. They had opinions and thoughts about the future, but also planned for it and set themselves goals. They invested in making these plans and dreams come true. It appears from the interviews that the future was seen as a kind of flexible space of experience. Their view of the "time they had left" expanded and contracted, depending on what they were speaking about in the interviews. There were three types of horizon for their expectations in each of the interviews: the horizon here and now, the horizon at some distance, and the distant horizon. The respondents shifted between these ways of looking at horizons of expectation. Respondents talked about a horizon which stretched from the immediate future to determined periods in the future, such as weeks, months or even 10-15 years ahead. There was also flexibility in terms of where these futures were projected to take place - at home, in the surrounding community or in the world. In talking about the future, respondents could say they had a future one moment, that they planned for it and expected to grow older, and then the next moment they would tone this down and say they lived for the moment. Previous research provides an image of elderly people as more oriented towards the present, and assumes their views of the future become more limited with age. This study, on the other hand, shows that older people's views of the future are more complex. The respondents did not seem to plan for the future in any kind of age-based pattern. Instead, they related to different horizons of expectation, shaped by their experiences and their current outlook on the future. 


\section{Final discussion}

The overarching themes resulting from this thesis include: a complex picture of dying, death and the future; age patterns; the third age; an extended life course; responsibility and control and integrity. These overarching themes make it possible to further our understanding of how older people relate to, and think about dying, death and their own future.

One conclusion from the overall study is that older people's thoughts and attitudes about their own death are complex and can also appear contradictory. They had different memories of the concept of death, and had had different experiences of it over the course of their lives. The respondents had lived through a historical time where social attitudes about death had varied enormously. Consequently, their views on the subject were a collage of these different attitudes. The way they saw their own future was also complex and contradictory. In their everyday lives, the respondents related to the future in different ways, both as a continuum and as different types of horizon of expectation. However, the future also involves death, and the respondents related to this in different ways. They also appeared to relate to parallel timetables or scenarios. On the one hand, they shifted between the different horizons of expectation, and on the other, they would try to postpone thinking about death, or delay thinking about it until the future. In this area of tension between trying to live life and knowing how transient it is, some respondents prepared for their death, for example, by "death cleaning", but also expressed a desire to live longer. Other respondents expressed a desire to live as long as possible and tried to prevent their worries about death to come into the open.

An interesting question is whether there are any age-related patterns in the participants' attitudes about dying, death and the future. I did not find any in the respondents' answers. Instead, their responses and attitudes were complex and not related to age. In the same way, there were no clear age patterns in terms of whether they thought about death in everyday life. Those who did think about it in my participant group came from different age groups. Even the concept of death being "untimely" was not linked to any age group among those interviewed.

The results of this study also have implications for how researchers regard "the third age". Relatively healthy elderly people are often called "third agers", but this study shows that even individuals in this group think about, plan, and talk about their own death and dying. In research, death is often linked to fourth agers. This study blurs the line between these distinctions, by showing that issues regarding death are present in the lives of both third and fourth agers. Being active and pursuing selffulfilling activities as an older person may also involve being responsible for 
planning, and taking control of death.

This study shows that it is fruitful to incorporate a future-oriented perspective into lifecourse studies which explore older people's views of death and dying. Views on "life after death", for instance, can also appear in the construction of the lifecourse - one which extends beyond death. The respondents mentioned a time after their own death in a number of different ways, which could be interpreted as a form of "extending life" or accessing "eternal life".

Responsibility was another central and underlying theme I identified from the interviews. It involved whether older people should be responsible for thinking about, and preparing for their own death, or whether this is an issue for those left behind. The issue of responsibility was very prevalent in the informants' stories, and also had different dimensions. Some thought the responsibility rested on their own shoulders, while others thought of it as a shared responsibility. Others even thought it was irresponsible not to think about and plan for the issues surrounding their own death. Some considered their family responsible for planning their burial, gravestone and related issues. They nevertheless felt that others put pressure on them to take it on themselves, even though they did not personally feel they should be responsible. Long before they died, individuals therefore felt some kind of pressure or responsibility to take charge of their own death.

Integrity was another overarching theme. What did integrity mean in the respondents' stories? Thinking about and planning for their future and their death involved exercising agency and control, but also involved ensuring a good death, and making it as dignified as possible. For instance, "death cleaning" and cleaning up after themselves at night, in case they should die in their sleep, provided a way of maintaining integrity and identity in death. Integrity could also involve having their loved ones around while they were dying, and planning for a good funeral service. For some, integrity was linked most of all to the time of death. A long and painful death, according to them, was a sorry way to die. It was something they feared, and they preferred euthanasia. On the other hand, integrity was also related to the future. The informants wanted to be treated with respect in the last years of their life. They did not wish to be considered a mere weight or burden to their family and to society. Living a life of integrity also meant being able to continue to live in their own home, having good relationships with their loved ones, feeling needed and belonging to civic groups. Integrity is used in this study in a broad and multifaceted way, and is linked to a sense of control and autonomy. Overall however, integrity relates to individuals being able to preserve their identity by thinking about dying, death and the future. 
Äldre människors föreställningar om den egna framtiden, döendet och döden

Translated by Joy Torgé 


\section{REFERENSER}

Aggedal, J-O. (2003). Lämna livet utan ceremoni. Äldre i centrum, 1/2003.

Aggedal, J-O. (2010). Har vi inte tid för döden? Dagens Nyheter, 101104.

Aiken, L. R. (1995). Aging: an introduction to gerontology. Oxford: Sage.

Alvesson, M. \& Sköldberg, K. (2008). Tolkning och reflektion. Vetenskapsfilosofi och kvalitativ metod. Lund: Studentlitteratur.

Alvsvåg, H. (1985). Vågar vi leva med döden? Lund: Studentlitteratur.

Andersson, L. (2002). Ensamhet och sociala relationer. I L. Andersson (red.). Socialgerontologi. Lund: Studentlitteratur.

Andersson, L. (2008). Ålderism. Lund: Studentlitteratur.

Andersson, L. (2009). Måste vi utplåna den fjärde åldern? I H. Jönsson (red.). Åldrande, åldersordning, ålderism. Norrköping: Linköpings universitet.

Andersson, L. \& Öberg, P. (2004). Diversity, health and ageing. I S. O. Daatland \& S. Biggs (red.). Ageing and Diversity: Multiple Pathways and Cultural Migrations. Bristol: The Policy Press.

Andersson, M. (2007). Äldre personers sista tid i livet. Livskvalitet, vård, omsorg och närståendes situation. Lund: Lunds universitet.

Andersson, Y. (2012). Bloggarna och döden. I A. Hirdman (red.). Döden i medierna: Våld, tröst, fascination. Stockholm: Carlssons.

Ariés, P. (1978). Döden: föreställningar och seder i västerlandet från medeltiden till våra dagar. Stockholm: Tiden.

Ariés, P. (1981). The hour of our death: the classic history of Western attitudes towards death over the last thousand years. London: Allen Lane.

Aspers, P. (2007). Etnografiska metoder: Att förstå och förklara samtiden. Malmö: Liber.

Bauman, Z. (1994). Döden och odödligheten i det moderna samhället. Göteborg: Daidalos.

Bengtson, V. L., Burgess, E. O., Parrott, T. M. \& Mabry, J. B. (2002). Ingenting är mer praktiskt användbart än en god teori. I L. Andersson (red.). Socialgerontologi. Lund: Studentlitteratur.

Berglund, I. (1994). Kyrkogårdens meditativa rum: besöket, upplevelsen, gestaltningen. Stockholm: Verbum.

Binstock, R. H. \& George, L. K. (2006). (red.). Handbook of aging and the social sciences. Boston MA; London: Academic Press.

Blennberger, E. (2005). Etik $i$ socialpolitik och socialt arbete. Lund: Studentlitteratur.

Brandstädter, J., Wentura, D. \& Greve, W. (1993). Adaptive resources of aging self: Outlines of an emergent perspective. International Journal of Behavioral Development, 18(2), 323-349. 
Bringéus, N-A. (2007). Livets högtidsdagar. Stockholm: Carlssons.

Bryman, A. (2009). Samhällsvetenskapliga metoder. Malmö: Liber.

Canetti, E. (1996). Urets hemliga hjärta: anteckningar 1973-1985. Stockholm: Forum.

Carstensen, L. L., Isaacowitz, D. M. \& Charles, S. T. (1999). Taking time seriously: A theory of socioemotional selectivity. American Psychologist, 54(3), 165-181.

Cicirelli, V. (2006). Older adults' views on death. New York NY: Springer.

Clarke, A. \& Warren, L. (2007). Hopes, fears and expectations about the future: what do older people's stories tell us about active ageing? Ageing $\mathcal{E}$ Society, 27, 465-488.

Cross, S. \& Markus, H. (1991). Possible selves across the life span. Human Development, 34, 230-255.

Cullberg, J. (1975). Kris och utveckling: en psykoanalytisk och socialpsykiatrisk studie. Stockholm: Natur och Kultur.

Dagens Nyheter, 130603.

Dahlberg, S. \& Hassling, P. (2012). Handbok för krisstöd och krisledning. Stockholm: Competenscompagniet.

Dahlgren, C. (2000). När döden skiljer oss åt... Anonymitet och individualisering $i$ dödsannonser: 1945-1999. Stockholm: Databokförlaget.

Dahlgren, C. \& Hermanson, J. (2006). "Här ska min aska vila" Nya platser och riter för gravsättning av aska på andra platser än begravningsplats. I

C. Dahlgren \& G. Gustafsson (red.). Kring begravningar i nutid: Tre studier. Lund: Lunds universitet.

DePoy, E. \& Gitlin, L. N. (1999). Forskning: en introduktion. Lund: Studentlitteratur.

Drolet, J-L. (1990). Transcending Death During Early Adulthood: Symbolic Immortality, Death Anxiety, and Purpose in Life. Journal of Clinical Psychology, 46(2), 148-160.

Edlund, M. (2002). Människans värdighet - ett grundbegrepp inom vårdvetenskap. Åbo: Åbo akademis förlag.

Ekvik, S. (2005). När gamla föräldrar dör: den undervärderade sorgen. Stockholm: Verbum.

Elias, N. (1985). The loneliness of the dying. Oxford: Blackwell.

Erikson, E. H., Erikson, J. M. \& Kivnick, H. Q. (1986). Vital involvement in old age: the experience of old age in our time. New York: Norton.

Feifel, H. (1959). Attitudes toward death in some normal and mentally ill populations. I H. Feifel (red.). The meaning of death. New York: McGraw-Hill.

Feigenberg, L. (1977). Terminalvård. Lund: Liber.

Fischler, C. (2008). Sveriges Radio P1.

Fischler, C. (2013). Dagens Nyheter, 130820.

Frostegren, M. L. (2000). Genom döden. Stockholm: Prisma.

Garth Vigilant, L. \& Williamson, J. B. (2003). Symbolic immortality and social theory: The relevance of an underutilized concept. I C. D. Bryant (red.). Handbook of Death and Dying, Volym 1. Newbury Park CA: Sage. 
Giddens, A. (1991). Modernity and self-identity: Self and society in the late modern age. Cambridge: Polity Press.

Giddens, A. (1999). Modernitet och självidentitet: Självet och samhället $i$ den senmoderna epoken. Göteborg: Daidalos.

Giddens, A. (2003). Sociologi. Lund: Studentlitteratur.

Giele, J. Z. \& Elder, G. H. (1998). Life course research: development of a field. I J. Z. Giele \& G. H. Elder (red.). Methods of life course research: Qualitative and Quantitative approaches. London: Sage.

Gieryn, T. F. (2000). A space for place in sociology. Annual Review of Sociology, 26, 463-496.

Giordano, J. A. (2000). Foreword. I A. Tomer (red.). Death attitudes and the older adult: Theories, concepts, and applications. Philadelphia PA: Routledge.

Glaser, B. G. (1978). Theoretical sensitivity: advances in the methodology of grounded theory. Mill Valley CA: Sociology Press.

Glaser, B. G. \& Strauss, A. L. (1980). Awareness of dying. New York: Aldine.

Gorer, G. (1965). Death, grief, and mourning. New York NY: Doubleday \& Co.

Guba, E. G. \& Lincoln, Y. S. (1994). Competing paradigms in qualitative research. I N. K. Denzin \& Y. S. Lincoln (red.). Handbook of qualitative research. Thousand Oaks CA: Sage.

Gunnarsson, E. (2009a). The welfare state, the individual and the need for care: older people's views. International Journal of Social Welfare, 18(3), 1-8.

Gunnarsson, E. (2009b). "I think I have had a good life": the everyday lives of older women and men from a lifecourse perspective. Ageing $\mathcal{E}$ Society, 29(1), 33-48.

Gunnarsson, E. (2013). “Man får inte stanna upp" - om äldre kvinnors och mäns vardagsliv och kroppens förändring. I M. Szebehely (red.). Genus i omsorgens vardag. Malmö: Gleerups.

Gustafsson, G. (2003). När det sociala kapitalet växlas in: Om begravningar och deltagandet $i$ begravningar. Lund: Studentlitteratur.

Gynnerstedt, K. (2011). Tredje åldern: I ett socialt medborgarskapsperspektiv. I K. Gynnerstedt \& M. Wolmesjö (red.). Tredje åldern - sociala aspekter och medborgarskap. Malmö: Gleerups.

Harrison, D. (2009). Svenska Dagbladet, 090712.

Hirdman, A. (2012). (red.). Döden i medierna: Våld, tröst, fascination. Stockholm: Carlssons.

Holstein, J. A. \& Gubrium. J. F. (2000). Constructing the life course. Dix Hills NY: General Hall.

Howarth, G. (1998). 'Just live for today': Living, caring, ageing and dying. Ageing and Society, 18(6), 673-689.

Howarth, G. (2000). Dismantling the boundaries between life and death. Mortality, (5), 127-138.

Howarth, G. (2007). Death $\mathcal{E}$ dying. A sociological introduction. Cambridge: Polity Press. 
Hägestadt, G. O. \& Neugarten, B. L. (1985). Age and life course. I R. H. Binstock \& E. Shanas (red.). Handbook of aging and social sciences. New York NY: Van Nostrand Reinhold.

Högerås, L. (2013). Barometern-OT, 131108.

Jecker, N. S. \& Schneiderman, L. J. (1994). Is dying young worse than dying old? The Gerontologist, 34(1), 66-72.

Jensen, O. W. \& Karlsson, H. (2001). Aktuell samhällsteori och arkeologi: introduktion till processuellt och postprocessuellt tänkande. Göteborg: Bricoleur Press.

Jeppsson Grassman, E. (2001). Tid, tillhörighet och anpassning. Kronisk sjukdom och funktionshinder ur ett livsloppsperspektiv. Socialvetenskaplig tidskrift, 4, 306-324.

Jeppsson Grassman, E. (2005). På jakt efter den frivilliga sektorns roll inom nordisk äldreomsorg. Forskning, gestaltningar och perspektiv. I M. Szebehely (red.). Äldreomsorgsforskning i Norden: en kunskapsöversikt. Köpenhamn: Nordiska ministerrådet.

Jeppsson Grassman, E. \& Whitaker, A. (2012). Omsorgens former och sammanhang: utgångspunkter och perspektiv. I E. Jeppsson Grassman \& A. Whitaker (red.). Aldrande och omsorgens gestaltningar: Mot nya perspektiv. Lund: Studentlitteratur.

Jeppsson Grassman, E. \& Whitaker, A. (2013). Ageing with disability: An introduction. I E. Jeppsson Grassman \& A. Whitaker (red.). Ageing with disability: A lifecourse perspective. Bristol: The Policy Press.

Johannisson, K. (2008). Förord. I L. Nilsson \& M. Persson (red.). Den mediala döden: Idéhistoriska variationer. Lund: Ellerströms Förlag.

Johansson, T. (2004). Anthony Giddens och det senmoderna. I P. Månsson (red.). Moderna samhällsteorier: Traditioner, tolkningar, teoretiker. Stockholm: Prisma.

Johnson, M. L. (2009). Spirituality, finitude, and theories of the life span.

I V. L. Bengtsson, M. Silverstein, N. M. Putney \& D. Gans (red.). Handbook of theories of aging. New York NY: Springer.

Jönson, H. (2002). Ålderdom som samhällsproblem. Lund: Studentlitteratur.

Kallenberg, K. (2007). Livsåskådning, död och trauma. I I. von Malmborg \& T. Silfving (red.). Att levandegöra döden: En antologi. Stockholm: Verbum.

Kastenbaum, R. (1974). Fertility and the Fear of Death. Journal of Social Issues, 30(4), 63-78.

Kellehear, A. (2007a). A social history of dying. Cambridge: University press.

Kellehear, A. (2007b). The end of death in late modernity: An emerging public health Challenge. Critical Public Health, 17(1), 71-79.

Koestenbaum, P. (1984). Min syn på livet och döden. Stockholm: Svenska Dagbladets Förlag.

Koselleck, R. (2004). Erfarenhet, tid och historia: om historiska tiders semantik. Göteborg: Daidalos.

Krekula, C., Närvänen A-L. \& Näsman, E. (2005). Ålder i intersektionell analys. Kvinnovetenskaplig tidskrift, (2), 81-94. 
Kvale, S. \& Brinkmann, S. (2009). Den kvalitativa forskningsintervjun. Lund: Studentlitteratur.

Kübler-Ross, E. (1988). Döden. Stockholm: Rabén \& Sjögren.

Lagergren, M. (1982). Tid för omsorg: slutrapport från projektet "Omsorgen $i$ samhället". Stockholm: Liber.

Lang, F. R. \& Carstensen, L. L. (2002). Time counts: future time perspective, goals, and social relationships. Psychology and Aging, 17, 125-139.

Lantz, G. (2010). Värdighet och de döda. I L. Nordenfelt (red.). Värdighet $i$ vården av äldre personer. Lund: Studentlitteratur.

Laslett, P. (1989). A fresh map of life: The emergence of the third age. London: Weidenfeld and Nicolson.

Laslett, P. (1994). The third age, the fourth age, and the future. Ageing $\mathcal{E}$ Soceity, 14(3), 436-447.

Liedman, S-E. (1997). I skuggan av framtiden: modernitetens idéhistoria. Stockholm: Bonnier Alba.

Lifton, R. J. (1974). On death and the continuity of life: "A new paradigm". History of childhood quarterly. The Journal of Psychohistory, 1(4), 681-696.

Lifton, R. J. (1979). The broken connection: On death and the continuity of life. New York NY: Simon and Schuster.

Lloyd, L. (2004). Mortality and morality: ageing and the ethics of care. Ageing $\mathcal{E}$ Society, 24(2), 235-256.

Lloyd, L. (2010). End-of-life issues. I D. Dannefer \& C. Phillipson (red.). The SAGE handbook of social gerontology. London: Sage.

Lloyd-Williams, M., Kennedy, V., Sixsmith, A. \& Sixsmith, J. (2007). The end of life: A qualitative study of the perceptions of people over the age of 80 on issues surrounding death and dying. Journal of Pain and Symptom Management, 34(1), 60-66.

Lukkarinen Kvist, M. (2007). En grav som ingen sköter är en sorglig syn. I Ö. Wahlbeck (red.). Ny migration och etnicitet $i$ Norden. Åbo: Åbo Akademi.

Lundmark, L. (1989). Tiden gång $\mathcal{E}$ tidens värde. Stockholm: Författarförlaget, Fischer \& Rye.

Magnusson, J. (2000). Traditionellt, modernt och postmodernt kring döden. Lund: Studentlitteratur.

Magnússon, F. (1996). Janusansiktet. Stockholm: Carlssons.

Magnússon, F. (2004). Modern död: Tabun, lockelse och längtan. I F. Magnússon \& L. Plantin (red.). Mångfald och förändring $i$ socialt arbete. Lund: Studentlitteratur.

Magnússon, F. (2009). Att tala om äldres död-en kulturanalys. Malmö: Liber. von Malmborg. I. \& Silfving, T. (2007). Ett evigt ämne. I I. von Malmborg \& T. Silfving (red.). Att levandegöra döden: En antologi. Stockholm: Verbum.

Marshall, V. W. (1995). Social models of aging. Canadian Journal on Aging, 14(1), 12-34. 
Mazzarella, M. (2012). Främlingars död förhöjer livskänslan. Svenska Dagbladet. 120514.

Mazzarella, M. (2012). Svenska Dagbladet. 120530.

McCoy, S. K., Pyszczynski, T., Solomon, S. \& Greenberg, J. (2000). Transcending the self: A terror management perspective on successful aging. I A. Tomer (red.). Death attitudes and the older adult: Theories, concepts, and applications. Philadelphia PA: Routledge.

Mitchell, J. C. (1983). Case and situation analysis. Sociological review, 31(2), 187211.

Mulkay, M. \& Ernst, J. (1991). The changing profile of social death. European Journal of Sociology, 32(1), 172-196

Neimeyer, R. A. (2000). Series foreword. I A. Tomer (red.). Death attitudes and the older adult: Theories, concepts, and applications. Philadelphia PA: Routledge.

Neugarten, B. L. (1979). Time, age, and life cycle. The American Journal of Psychiatry, 136(7), 887-894.

Nilsson, M., Sarvimäki, A. \& Ekman, S-L. (2003). The meaning of future for the oldest old. Internationel Journing Aging and Human Development, 56(4), 345-364.

Nilsson, R. (2008). Döden: en del av livet. Halmstad: Bulls Graphics.

Nordenfelt, L. (2003). Dignity and the care of the elderly. Medicine, Health Care and Philosophy, 6, 103-110.

Nordenfelt, L. (2010). Begreppet värdighet. I L. Nordenfelt (red.). Värdighet $i$ vården av äldre personer. Lund: Studentlitteratur.

Nuland, S. B. (1994). Hur vi dör: reflektioner över livets slut. Stockholm: Bromberg.

Nurmi, J-E. (2005). Thinking about and acting upon the future: Development of future orientation across the life span. I A. Strathman \& J. Joireman (red.). Understanding behavior in the context of time: Theory, research, and application. Mahwah NJ: Lawrence Erlbaum.

Närvänen, A-L. (1994). Temporalitet och social ordning. Linköping: Linköpings universitet.

Pilcher, J. (1995). Age and generation in modern Britain. Oxford: Oxford University Press.

Qvarnström, U. (1978). Patients'reactions to impending death. A clinical study. Stockholm: Stockholms universitet.

Rahm Hallberg, I. (2004). Death and dying from old people's point of view: A literature review. Aging Clinical and Experimental Research, 16(2), 87-103.

Rahm Hallberg, I. (2010). Livets sista skeden, döden och döendet. I A. Ekwall (red.). Äldres hälsa och ohälsa: en introduktion till geriatrisk omvårdnad. Lund: Studentlitteratur.

Rao, R., Dening, T., Brayne, C. \& Huppert, F. A. (1997). Attitudes toward death: A community study of octoagenarians and nonagenarians. International Psychogeriatrics, 9(2), 213-221. 
Rowe, J. W. \& Kahn, R. L. (1997). "Successful Aging". The Gerontologist, 37(4), 433-440.

Ryan, G. W. \& Bernard, H. R. (2003). Techniques to identify themes. Field Methods, 15(1), 85-109.

Sandman, L. (2001). A good death. On the value of death and dying. Göteborg: Göteborgs universitet.

Seale, C. (1998). Constructing death: the sociology of dying and bereavement. Cambridge: Cambridge University Press.

Silfving, T. (2007). Döden: en försummad och missförstådd del av livet. Ett existentiellt perspektiv. I I. von Malmborg \& T. Silfving (red.). Att levandegöra döden: En antologi. Stockholm: Verbum.

Skarin Frykman, B. (1994). Det skulle visas utåt att man hade lik i huset... Om arbetarbegravningar i Göteborg vid sekelskiftet 1900. I K. Söderpalm (red.). Dödens riter. Stockholm: Carlssons i samarbete med Göteborgs stadsmuseum.

Smith, J. \& Freund, A. M. (2002). The dynamics of possible selves in old age. Journal of Gerontology: Psychological Sciences, 57(6), 492-500.

Socialstyrelsen (2004). God vård i livets slut: En kunskapsöversikt om vård och omsorg om äldre. Stockholm: Socialstyrelsen.

Socialstyrelsen (2007). Forskning som speglar vården i livets slut. Stockholm: Socialstyrelsen.

SOU (2002:29). Riv ålderstrappan! Livslopp i förändring. Stockholm: Socialdepartementet.

SOU (2003:91). Äldrepolitik för framtiden. Stockholm: Socialdepartementet.

Strang, P. (2007). Livsglädje och det djupa allvaret: om existentiell kris och välbefinnande. Stockholm: Natur och Kultur.

Stroebe, M. \& Schut, H. (1999). The dual process model of coping with bereavment: Rationale and description. Death Studies, 23(3), 197-224.

Svenska Dagbladet, 130526.

Sydsvenskan, 091102.

Söderlind, I. \& Engwall, K. (2008). "Barnen är framtiden": Barn i framtidsdiskussion och framtidsstudier. I S. Alm \& J. Palme (red.). Fjorton perspektiv på framtiden: Samhälls- och humanvetenskapliga framtidsstudier. Stockholm: Institutet för framtidsstudier.

Sörensen, A-B. (2006). Kyrkogården: ett grönt kulturarv. I L. Åkesson (red.). Inför döden. Höganäs: Edition Andersson.

Taghizadeh Larsson, A. (2011). I tredje åldern med personlig assistans: äldreomsorg och social medborgarskap. I K. Gynnerstedt \& M. Wolmesjö (red.). Tredje åldern: sociala aspekter och medborgarskap. Malmö: Gleerups.

Takkinen, S. \& Ruoppila, I. (2001). Meaning in life in three samples of elderly persons with high cognitive functioning. The International Journal of Aging and Human Development, 53(1), 51-73. 
Taylor, S. J. \& Bogdan, R. (1984). Introduction to qualitative research methods: the search for meanings. New York NY: Wiley.

Taylor, S. J. \& Bogdan, R. (1998). Introduction to qualitative research methods. New York NY: John Wiley and Son.

Ternestedt, B-M. (1998). Livet pågår! Om vård av döende. Stockholm: Vårdförbundet.

Ternestedt, B-M. (2010). En värdig död och en identitetsfrämjande vård. I L. Nordenfelt (red.). Värdighet $i$ vården av äldre personer. Lund: Studentlitteratur.

Thelin, A. (2011). Tredje åldern: ett mångtydigt och problematiskt begrepp. I K. Gynnerstedt \& M. Wolmesjö (red.). Tredje åldern: sociala aspekter och medborgarskap. Malmö: Gleerups.

Thomsson, H. (2002). Reflexiva intervjuer. Lund: Studentlitteratur.

Thorslund, M. (2012). Hälsa och ohälsa bland äldre. I L. Andersson \& P. Öberg (red.). Jämlik ålderdom? I samtiden och framtiden. Malmö: Liber.

Tomer, A. (2000a). Preface. I A. Tomer (red.). Death attitudes and the older adult: Theories, concepts, and applications. Philadelphia PA: Routledge.

Tomer, A. (2000b). Death-related attitudes: conceptual distinctions. I A. Tomer (red.). Death attitudes and the older adult: Theories, concepts, and applications. Philadelphia PA: Routledge.

Tomer, A., Eliason, G. \& Smith, J. (2000). The structure of the revised death anxiety scale in young and old adults. I A. Tomer (red.). Death attitudes and the older adult: Theories, concepts, and applications. Philadelphia PA: Routledge.

Tornstam, L. (2005). Åldrandets socialpsykologi. Stockholm: Norstedts.

Tornstam, L., Odén, B. \& Svanborg, A. (1982). Äldre i samhället: förr, nu och $i$ framtiden. D. 1: Teorier och forskningsansatser. Stockholm: Liber.

Tornstam, L., Odén, B. \& Svanborg, A. (1983). Äldre i samhället: förr, nu och $i$ framtiden. D. 2: Probleminventeringar. Stockholm: Liber.

Tännsjö, T. (2009). Döden är förhandlingsbar. Stockholm: Liber.

Vestlund, G. (2008). Förord. I R. Nilsson (red.). Döden: en del av livet. Halmstad: Bulls Graphics.

Vetenskapsrådet. (2013). Forskningsetiska principer inom humanistisksamhällsvetenskaplig forskning. Stockholm: Vetenskapsrådet.

Vincent, J. A., Phillipson, C. \& Downs. M. (2006). (red.). The futures of old age. London: Sage.

Walter, T. (1994). The revival of death. London: Routledge.

Walter, T. (2008). The sociology of death. Sociology Compass, 2(1), 317-336.

Walter, T. (2013). Choice or care? Neo-liberal theory and end-of-life practice. Conference Paper, The $11^{\text {th }}$ International death, Dying and Disposal Conference. $5^{\text {th }}-8^{\text {th }}$ September, 2013.

Wasling. P. (2013). Minnet fram och tillbaka. Stockholm: Volante.

Wenger, G. C. (2002). Interviewing older people. I J. F. Gubrium \& J. A. Holstein (red.). Handbook of interview research: context and method. London: Sage. 
Whitaker, A. (2004). Livets sista boning: Anhörigskap, åldrande och död på sjukhem. Stockholm: Stockholms universitet.

Whitaker, A. (2009). Åldrande, död och anhörigskap. Malmö: Gleerups.

Whitaker, A. (2010). The body as existential midpoint: the aging and dying body of nursing home residents. Journal of Aging Studies, 24(2), 96-110.

Whitaker, A. (2013). Death and dying in the Nordic countries: Three personal images. I M. H. Jacobsen (red.). Deconstructing death: Changing cultures of death, dying, bereavement and care in the Nordic countries. Odense: University Press of Southern Denmark.

Widerberg, K. (2002). Kvalitativ forskning i praktiken. Lund: Studentlitteratur.

Wong, P. T. P. (1998). Spirituality, meaning and successful aging. I P. T. P. Wong \& P. S. Fry (red.). The human quest for meaning: A handbook of psychological research and clinical applications. Mahwah NJ: Lawrence Erlbaum Associates.

Wong, P. T. P. (2000). Meaning of life and meaning of death in successful aging. I A. Tomer (red.). Death attitudes and the older adult: Theories, concepts, and applications. Philadelphia PA: Routledge.

Wortman, C. B. \& Boerner, K. (2006). Beyond the myths of coping with loss: Prevailing assumptions versus scientific evidence. I H. S. Friedman \& R. Cohen Silver (red.). Foundation of healthy psychology. Oxford: Oxford University Press.

Ågren, M. (1995). - en dag i taget: en rapport om livet vid 92 års ålder. Jönköping: Institutet för gerontologi.

Ågren, M. (1998). Life at 85 and 92: A qualitative longitudinal study of how the oldest old experience and adjust to the increasing uncertainty of existence. Jönköping: Institutet för gerontologi.

Ågren Bolmsjö, I. (2006). Känslor och tankar kring döden. I L. Åkesson (red.). Inför döden. Höganäs: Edition Andersson.

Åhrén Snickare, E. (2002). Döden, kroppen och moderniteten. Stockholm: Carlssons.

Åkesson, L. (1997). Mellan levande och döda: föreställningar om kropp och ritual. Stockholm: Natur och Kultur.

Öberg, P. (2002). Livslopp i förändring. I L. Andersson (red.). Socialgerontologi. Lund: Studentlitteratur.

Ödman, P-J. (2007). Tolkning, förståelse, vetande: Hermeneutik $i$ teori och praktik. Stockholm: Norstedts.

Österlind, J. (2009). När livsrummet krymper: vård och omsorg av äldre personer $i$ livets slutskede. Örebro: Örebro universitet. 



\section{INFORMATIONSBREV}

Mitt namn är Magnus Broström och jag är doktorand på Linköpings universitet, verksam inom Nationella Institutet för forskning om äldre och åldrande. Min forskning handlar om äldres erfarenheter, tankar och föreställningar om framtid, livets sista skeden, döende och död. Här är det viktigt att äldre människor själva får komma till tals. Inom det projekt som jag nu arbetar med avser jag därför att intervjua personer som är 70 år eller äldre och som bor i ordinärt boende om dessa frågor. Detta informationsbrev är en förfrågan om Du skulle kunna tänka Dig att delta genom en intervju. Dina synpunkter kommer att vara ovärderliga och Du får samtidigt en möjlighet att vara med och bidra till ökad kunskap på detta område.

Intervjun kommer uppskattningsvis att ta mellan en till två timmar. Du kommer att ha möjlighet att bestämma tid för intervjun och plats där Du föredrar att bli intervjuad: på min arbetsplats, i Ditt hem eller på något annat ställe.

Din medverkan i intervjun är frivillig, Du bestämmer om Du vill delta eller om Du önskar avstå, och Du kan avbryta Din medverkan när Du vill. Du kommer att avidentifieras så att ingen utanför forskningsprojektet kan känna igen Dig. Materialet som framkommer vid intervjun med Dig kommer endast att användas för forskningsändamålet. Du har också möjlighet att erhålla projektets slutresultat om så önskas.

Om Du är intresserad av att delta i projektet eller har andra frågor som rör projektet så är Du välkommen att ta kontakt med mig eller mina handledare via telefon eller e-post.

Med vänlig hälsning

Magnus Broström

Doktorand

Linköpings univ.

60174 Norrköping

Tel: 011-xx xx xx

E-post:
Eva Jeppsson-Grassman

Handledare, professor

Linköpings univ.

60174 Norrköping

Tel: 011-xx xx xx

E-post:
Anna Whitaker

Bi. handledare, docent Linköpings univ. 60174 Norrköping

Tel: 011-xx xx xx

E-post: 



\section{INTERVJUGUIDE}

(Den version av intervjuguide som användes vid intervjuerna med de fem sista intervjupersonerna.)

Mitt projekt handlar om äldres egna erfarenheter, tankar och föreställningar om framtid, livets sista faser, döende och död och under intervjun kommer jag att ställa olika frågor som berör dessa teman, men först undrar jag om du med egna ord vill berätta lite om dig själv, lite om din bakgrund och vem du är som person?

$$
\begin{aligned}
& \text { I Vardagslivet } \\
& \text { - familjeförhållande } \\
& \text { - utbildning } \\
& \text { - ålder } \\
& \text { - uppväxt } \\
& \text { - platser du har bott på } \\
& \text { - boende } \\
& \text { - arbete } \\
& \text { - fritid } \\
& \text { - hälsa } \\
& \text { - umgänge, vänner }
\end{aligned}
$$

\section{Tillbakablick}

1. Hur har ditt liv varit? Berätta. Exempelvis om några positiva händelser.

\section{Framtiden}

- Berätta hur du upplever att det är att bli äldre/gammal?

- På vilka sätt märker du att dina vänner åldras?

- Oror du dig något för din egen åldrande kropp?

- Är det något annat du funderar över i samband med ditt eget åldrande?

- Hur tänker du kring din framtid?

- Tänker du någonsin på hur gammal du kommer att bli?

- På vilka sätt kommer familjen, omgivningen att påverka din framtid, tror du?

- Hur skulle den ideala framtiden se ut för dig?

- Har du några framtidsdrömmar? Är det någonting du skulle vilja hinna med?

- Har du omsorg i dag?

- Vad innebär ditt egna hem för dig?

- Vad innebär ett särskilt boende för dig?

- Har du funderat något kring om du framöver behöver flytta till ett särskilt boende? 
IV Egna erfarenheter av döende och död, ett tillbakablickande perspektiv

- Vad förknippar du döende och död med?

- Vilka är dina tidigaste minnen/erfarenheter av döende och död? Berätta.

- Har du sett någon död människa någon gång? Berätta.

- Har du varit med och vårdat någon döende? Berätta.

- Kan du erinra dig när, vid vilka tidpunkter i ditt liv, som döende och död har blivit mer påtaglig?

- Är det någons död som har betytt något särskilt för dig?

\section{Tankar och föreställningar om ditt eget döende och död}

- Har du varit med om någonting i ditt liv som har påverkat hur du ser på din egen död?

- Tänker du på döende och död, nuförtiden?

- Om nej...Hur kommer det sig tror du?

- Om ja...Vad beror det på tror du att du tänker på döende och död?

- Tänker du olika om döendet och döden? Berätta.

- Finns det någon du idag kan dela dina tankar med angående döende och död?

- När var du på en kyrkogård senast?

- Hur ser dina funderingar ut kring ditt eget döende och död?

- En hypotetisk fråga, men kommer det att bli viktigt för dig att få bestämma vem som skall vara med dig när du dör?

- Hur skulle du vilja dö, om du själv fick bestämma?

\section{Egen död, begravning och grav}

- Har du planerat på något vis för hur det skall bli efter din död?

- Begravningen? Berätta.

- Har du funderat på att skriva något testamente?

- Var och hur skulle du vilja bli begravd?

- Är det viktigt att du följer traditionen här, tycker du?

- Hur viktigt är det att någon går på din begravning och att någon besöker den plats där du blir begravd?

- Vad tror du kommer att hända efter döden? Berätta.

- Hur vill du bli ihågkommen?

\section{Döende och död i vardagslivet}

- När pratas det om döende och död i vardagen, tycker du?

- Var i vardagslivet ser du döende och död?

- Vems döende och död tycker du syns i vardagslivet?

- Vad sägs det om döende och död, tycker du?

- Ibland sägs det, i vår kultur, att det är svårt att prata om döden, vad tycker $\mathrm{du}$ ? 
- Ibland pratas och skrivs det om äldre människors döende och död i tidningar och på TV, hur beskrivs äldre människors döende och död i vardagen, tycker du?

\section{Avslutning}

- Är du med i någon förening, utövar du någon sport eller har du några konstnärliga talanger?

- Är det någonting som du vill fråga om, något som är oklart, något som vi har missat att samtala om, tycker du? 